Florida International University FIU Digital Commons

$11-7-2014$

\title{
Valuation of Ecosystem Services for Environmental Decision Making in South Florida
}

Nadia A. Seeteram

Florida International University, nseet001@fiu.edu

DOI: $10.25148 /$ etd.FI14110740

Follow this and additional works at: https://digitalcommons.fiu.edu/etd

Part of the Other Economics Commons

\section{Recommended Citation}

Seeteram, Nadia A., "Valuation of Ecosystem Services for Environmental Decision Making in South Florida" (2014). FIU Electronic Theses and Dissertations. 1636.

https://digitalcommons.fiu.edu/etd/1636

This work is brought to you for free and open access by the University Graduate School at FIU Digital Commons. It has been accepted for inclusion in FIU Electronic Theses and Dissertations by an authorized administrator of FIU Digital Commons. For more information, please contact dcc@fiu.edu. 


\title{
FLORIDA INTERNATIONAL UNIVERSITY \\ Miami, Florida
}

\section{VALUATION OF ECOSYSTEM SERVICES FOR ENVIRONMENTAL DECISION MAKING IN SOUTH FLORIDA}

\author{
A thesis submitted in partial fulfillment of the \\ requirements for the degree of \\ MASTER OF SCIENCE \\ in \\ ENVIRONMENTAL STUDIES \\ by
}

Nadia A. Seeteram

2014 
To: Interim Dean Michael R. Heithaus

College of Arts and Sciences

This thesis, written by Nadia A. Seeteram, and entitled Valuation of Ecosystem Services for Environmental Decision Making in South Florida, having been approved in respect to style and intellectual content, is referred to you for judgment.

We have read this thesis and recommend that it be approved.

Mahadev G. Bhat

Michael Sukop

Pallab Mozumder, Major Professor

Date of Defense: November 7, 2014

The thesis of Nadia A. Seeteram is approved.

Interim Dean Michael R. Heithaus

College of Arts and Sciences

Dean Lakshmi N. Reddi

University Graduate School

Florida International University, 2014 
C) Copyright 2014 by Nadia A. Seeteram All rights reserved. 


\section{DEDICATION}

I dedicate this thesis to my brother Rainer, and my cousins Christina, Jonathan, Tushar, Kieran, Mahesh, Shay, and Krish. May you always seek answers to seemingly unanswerable questions. I also dedicate this thesis to my loving parents, Ramchal and Kamilla Seeteram. Without your encouragement, patience, and love, I could not have flourished into the inquisitive, young woman I am today. 


\section{ACKNOWLEDGMENTS}

I would like to thank my major advisor, Dr. Pallab Mozumder, for his enduring support, guidance, and patience throughout my graduate career. I am truly grateful to him for granting me the opportunity to work on the SFWSC Project, and for his belief in my capabilities for completing this project. I am sincerely thankful for the innumerable hours he dedicated towards working with me, and for cultivating my interest in valuation of environmental goods and services. I would also like to extend my sincere gratitude towards the members of my graduate committee, Dr. Mahadev Bhat and Dr. Michael Sukop, for their encouragement and advice over the course of this project. Also, I would like to thank the Department of Earth and Environment, and Dr. Krish Jayachadran, for awarding me the assistantships that allowed me to complete my graduate degree.

I would like to thank Dr. Victor Engel for his invaluable contributions to the research project in his de facto role as ecological advisor. I could not have completed this project without his exhaustive knowledge of the Everglades and the precious time he took in bestowing that knowledge upon me. I would like to express my sincere appreciation to Dr. Jianbin Zhu, for his substantial contribution towards statistical consultation throughout this research process. I wish to convey my utmost gratitude towards Dr. Elizabeth Anderson for her steadfast guidance, invaluable friendship, and for being a truly insightful teacher. Also, I would like to thank Seema Sah and Gail Excel for their unwavering support and kindness throughout my time at FIU. Finally, I would like to acknowledge the 2,905 respondents who participated in our survey for their impassioned commitment towards improving South Florida. 


\section{ABSTRACT OF THE THESIS \\ VALUATION OF ECOSYSTEM SERVICES FOR ENVIRONMENTAL DECISION MAKING IN SOUTH FLORIDA by}

Nadia A. Seeteram

Florida International University, 2014

Miami, Florida

Professor Pallab Mozumder, Major Professor

The current study aims at understanding public preferences for restoration and generating willingness to pay (WTP) values for restored ES through the implementation of a discrete choice experiment. A previous study (Milon et al., 1999) generated WTP values amongst Floridians of up to $\$ 3.42$ - $\$ 4.07$ billion for full restoration over a 10 -year period. We have collected data from 2,905 respondents taken from two samples who participated in an online survey designed to elicit the WTP values for selected ecological and social attributes included in the earlier study (Milon et al. 1999). We estimate that the Florida general public is willing to pay up to $\$ 854.1$ - $\$ 954.1$ million over 10 years to avoid restrictions on their water usage and up to $\$ 90.8$ - $\$ 183.7$ million over 10 years to restore the hydrological flow within the Water Conservation Area. 


\section{TABLE OF CONTENTS}

CHAPTER

PAGE

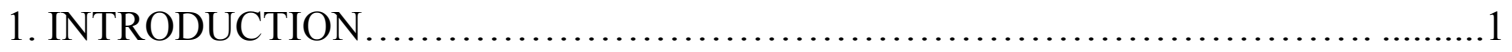

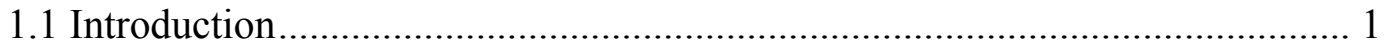

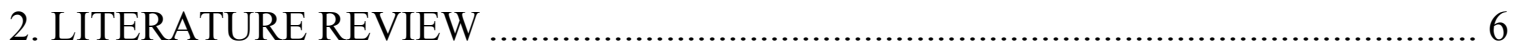

2.1 The Everglades- The Past, The Present, and The Plans for Restoration.............6

2.1.1 The Significance of the Everglades.................................6

2.1.2 The Central \& Sothern Florida Flood Control Project and Its Effects .......................................................................................

2.1.3 The Comprehensive Everglades Restoration Project (CERP).......10

2.2 Ecosystem Services (ES) ............................................... 12

2.2.1 Ecosystem Services with the Everglades System.......................13

2.3 Economic Valuation of Ecosystem Services ...................................................18

2.3.1 Stated Preference Methods ........................................................... 20

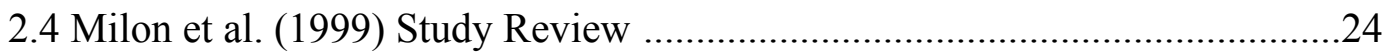

2.4.1 Milon et al. (1999) Study Methods ................................................. 22

2.4.2 Milon et al. (1999) Study Results and Conclusions ..........................28

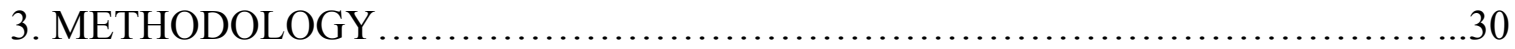

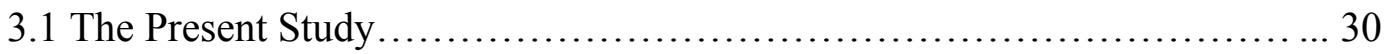

3.1.1 Attribute Selection.........................................28

3.1.2 South Florida Water, Sustainability, Climate Project (SFWSC)

and Motivation .......................................................................................32

3.1.3 Ecological Attributes.............................................33

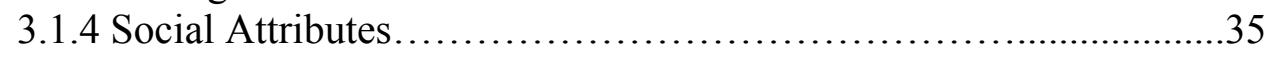

3.1.5 Levels within Choice Cards/ SAS Process............................... 37

3.1.6 Description of Informational Videos.............................41

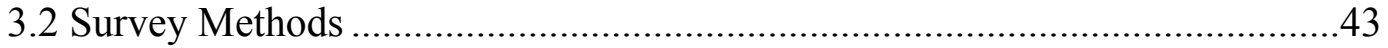

3.2.1 Methodology ...................................................... 43

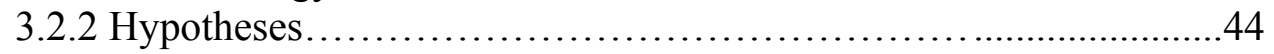

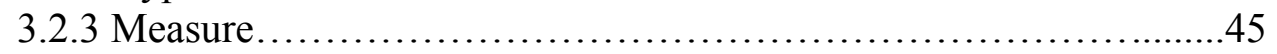

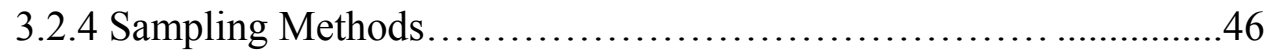

3.2.5 Survey Dissemination and Responses.............................47

3.2.6 Respondent Demographics...................................... 47

3.2.7 Survey Analysis.............................................. 51

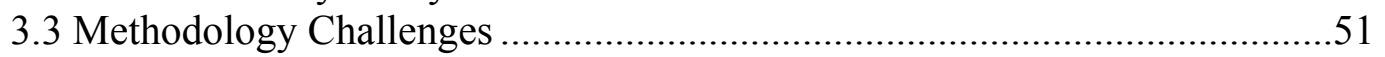

3.3.1 Methodlogy Challenges ....................................................................51

3.3.2 Addressing Sampling Methodology '.................................................53

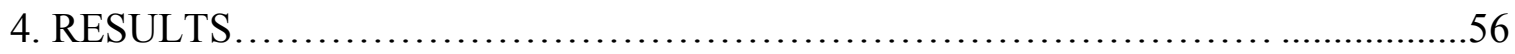

4.1 Descriptive Results- Primary Analysis....................................56

4.4.1 Respondent Characteristics........................................56 
4.2 Restoration Plan Attribute Selection by Level- Choice cards adapted

from Milon et al. (1999)...

4.2.1. Hydrological Model Restoration Plan Attribute Selection

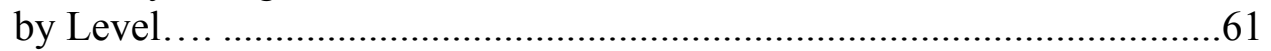

4.2.2. Species Model Restoration Plan Attribute Selection by Level .......62

4.3 Management Plan Attribute Selection by Level................................ 64

4.3.1 Management Plan Attribute Selection by Level - General Public .. 64

4.3.2 Management Plan Attribute Selection by Level-

Saltwater Anglers ...........................................................................67

4.4 Decisions by Choice Card and Sample Population ....................... 70

4.4.1 Decisions by Individual Choice Cards for the Hydrological Model

for the Milon et al. (1999) adapted choice cards .70

4.4.2 Decisions by Individual Choice Cards for the Species Model

for the Milon et al. (1999) adapted choice cards ...................................74

4.4.2.1 Trends within the Hydrological and Species

Model Milon et al. (1999) adapted Choice Cards................ 78

4.4.3 Decisions by Individual Choice Cards for the Newly Created

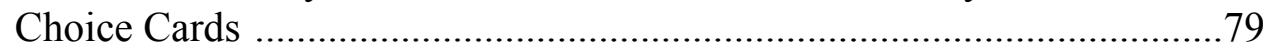

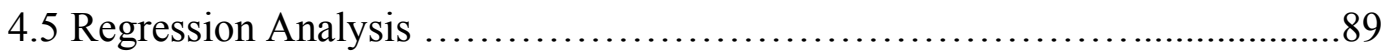

4.5.1 Variable Descriptions........................................89

4.5.2 General Public Sample Population Regression Analysis...............90

4.5.3 Saltwater Anglers Sample Population Regression Analysis............97

4.6. Willingness to Pay Values......................................... 103

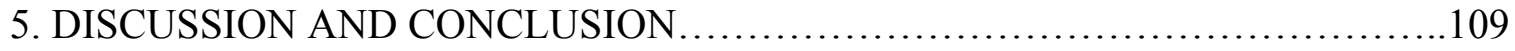

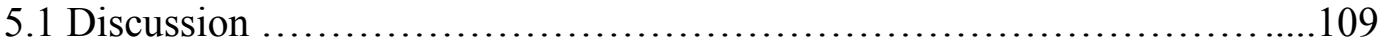

5.1.1 Willingness to Pay Values for Ecological and Social Attributes.....109

5.1.1.1 Water Conservation Areas-Hydrological Model .............109

5.1.1.2 Wetland, Dryland, and Florida Bay Species- Species

Model WTP ........................................................................109

5.1.1.3 Restrictions on Water Usage........................................110

5.1.2 Comparison of Current Study Results and Milon et at. (1999) .....113

5.1.2.1 Partial and Full Restoration- Current Study v.

Milon et al. (1999) ................................................................114

5.1.2.2 Lower Willingness to Pay Values................................117

5.1.3 Hypothesis Testing...........................................118

5.1.4 External Validation of Results.................................119

5.1.5 Cognitive Dissonance .............................................................120

5.1.6 Policy Recommendations...................................................122

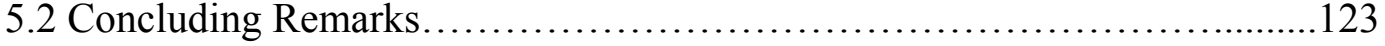

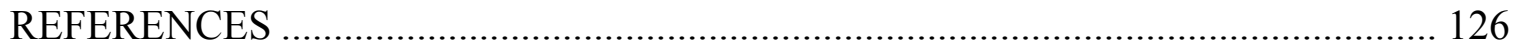

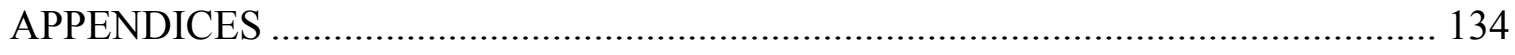




\section{LIST OF TABLES}

TABLE

PAGE

Table 2.1: Population Projections for South Florida 2012- 2040.........................23

Table 2.2: List of Ecological and Social Attributes Considered in Milon et al. (1999) ....27

Table 2.3:WTP Values for Selected Restoration Plans from Milon et al (1999)..........28

Table 3.1: Milon et al (1999) Attributes Included in the Present Study...................31

Table 3.2: Ecological and Social Attributes Included in the Present Study Not Previously Considered in the Milon et al. (1999) ...........................................................31

Table 3.3: Short Descriptions of the New Attributes for Modified Choice Card......... 36

Table 3.4 Respondents Demographics within the General Public and Saltwater Anglers Sample Population as Compared to Florida Census Demographics.

Table 3.5 Revised Figures for Respondent Demographics within the General Public and Saltwater Anglers Sample Population as Compared to Florida Census

Demographics

Table 4.1: General Public Respondent Characteristics- Frequency of Recreational

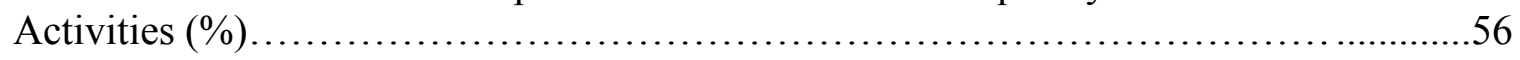

Table 4.2: Saltwater Anglers Respondent Characteristics- Frequency of

Recreational Activities (\%)

Table 4.3: Choice Selection Frequency for Hydrological Model-

Milon et al. (1999)....

Table 4.4: Choice Selection Frequency for Species Model- Milon et al. (1999).........63

Table 4.5: Choice Selection Frequency for Management Plan Attributes-

General Public.

Table 4.6: Choice Selection Frequency for Management Plan Attributes-

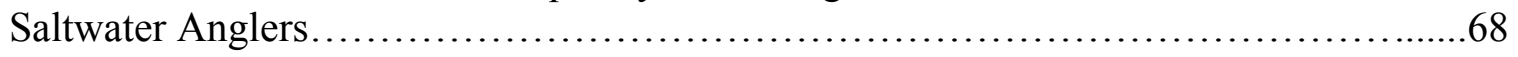

Table 4.7: Hydrological Model Choice Card Decisions: Cards 1- 5...................70

Table 4.8: Hydrological Model Choice Card Decisions: Cards 6- 10.................71 
Table 4.9: Hydrological Model Choice Card Decisions: Cards 11-15....................72

Table 4.10: Hydrological Model Choice Card Decisions: Cards 16-20..................73

Table 4.11: Species Model Choice Card Decisions: Cards 21-25......................74

Table 4.12: Species Model Choice Card Decisions: Cards 26-30....................75

Table 4.13: Species Model Choice Card Decisions: Cards 31-35....................... 76

Table 4.14: Species Model Choice Card Decisions: Cards 36-40...................78

Table 4.15: Choice Card 41 Decision......................................... 80

Table 4.16: Choice Card 42 Decision.......................................... 80

Table 4.17: Choice Card 43 Decision.......................................... 81

Table 4.18: Choice Card 44 Decision......................................... 81

Table 4.19: Choice Card 45 Decision......................................... 81

Table 4.20: Choice Card 46 Decision......................................... 82

Table 4.21: Choice Card 47 Decision......................................... 82

Table 4.22: Choice Card 48 Decision.........................................83

Table 4.23: Choice Card 49 Decision.......................................... 83

Table 4.24: Choice Card 50 Decision........................................84

Table 4.25: Choice Card 51 Decision............................................ 84

Table 4.26: Choice Card 52 Decision.......................................... 85

Table 4.27: Choice Card 53 Decision........................................ 85

Table 4.28: Choice Card 54 Decision........................................ 85

Table 4.29: Choice Card 55 Decision......................................... 86

Table 4.30: Choice Card 56 Decision....................................... 86

Table 4.31: Choice Card 57 Decision...................................... 87 
Table 4.32: Choice Card 58 Decision........................................... 87

Table 4.33: Choice Card 59 Decision............................................ 88

Table 4.34: Choice Card 60 Decision............................................... 88

Table 4.35: Variable Description List Used in Regression Analysis.....................89

Table 4.36: Regression Output for Hydrological Model- General Public............... 91

Table 4.37: Regression Output for Species Model- General Public......................94

Table 4.38: Regression Output for Hydrological Model- Saltwater Anglers............. 97

Table 4.39: Regression Output for Species Model- Saltwater Anglers ............................100

Table 4.40: Marginal Willingness to Pay $(m W T P)$ values per Attribute ..........................104

Table 4.41: Willingness to Pay (WTP) values for Both Sample Populations...............104

Table 5.1: Application of Water Use Restrictions to Average Single Family

Residential Monthly Water Consumption (Gallons) .........................................................111

Table 5.2 Hydrological and Species Co-efficients and $m W T P$ Comparison between Milon et al. (1999) and the Current Study ....................................................................114

Table 5.3 WTP values for Hydrological Partial and Full Restoration from Milon and

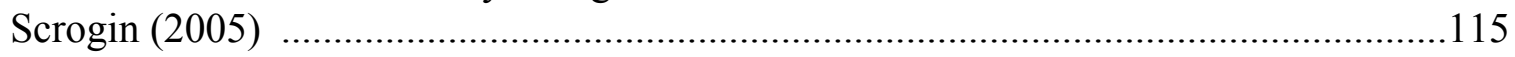

Table 5.4 WTP values for Species Partial and Full Restoration from Milon and

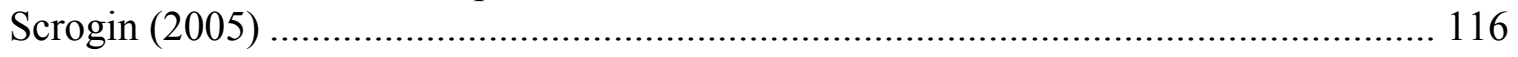

Table 5.5 WTP values for Partial and Full Restoration in Current Study ..................... 116 


\section{LIST OF FIGURES}

\section{FIGURE}

PAGE

Figure 2.1: A comparision of the Historic Everglades (left) and the

Current Everglades (right. 8

Figure 2.2: Map of the water management areas governed by the SFWMD..............9

Figure 2.3: Summary of ES Valuation of Everglades Restoration from McCormick et al. (2010).

Figure 2.4: List Ecological and Social Attributes Considered in Milon et al (1999)......25

Figure 3.1: Hydrological Model Choice Card Example Adapted from Milon et al. (1999)

Figure 3.2: Species Model Choice Card Example Adapted from Milon et al. (1999) ......40

Figure 3.3: Choice Card with Additional Attributes Example...........................41

Figure 3.4: Screenshot of the survey hosted on the Qualtrics Platform................45

Figure 3.5: Screenshot of the embedded video within the survey on the Qualtrics Platform.

Figure 4.1: General Public Respondents - Climate Change Attitudes (\%)...............59

Figure 4.2: Saltwater Angler Respondents - Climate Change Attitudes (\%).............60

Figure 4.3: Priorities for Environmental Public Policy: Protecting the Environment vs. Economic Growth (\%) - General Public and Saltwater Angler Respondents .60 


\section{ABBREVIATIONS AND ACRONYMS}

CERP

CS\&F

CVM

EAA

ENP

ES

MA

MAUT

mWTP

NPV

RA

SFWMD

SFWSC

SLE

SP

WASD

WCA

WTP
The Comprehensive Everglades Restoration Plan

The Central and South Florida Project

Contingent Valuation Methods

Everglades Agricultural Area

Everglades National Park

Ecosystem Services

Millennium Ecosystem Assessment

Multi-Attribute Utility Theory

Marginal Willingess to Pay

Net Present Value

Recreational Activities

South Florida Water Management District

South Florida Water, Climate, Sustainability

St. Lucie Estuary

Stated Preferences

Miami Dade Water And Sewer Department

Water Conservation Areas

Willingness to Pay 


\section{CHAPTER 1: INTRODUCTION}

\subsection{Introduction}

The Everglades is a vast freshwater wetland system that spans from the Kissimmee River watershed, which drains through Lake Okeechobee in Central Florida and empties into the Florida Bay in southern Florida (Light and Dineen, 1994). This system is the largest subtropical wetland in North America, as the historic extent of the Everglades once flowed over 28,490 sq. km (Perry, 2008; Perry, 2004) like a river of grass until it reached Florida Bay. Presently, the current extent of the Everglades has been reduced to about 50\% of its original size (Perry 2008; Perry, 2004). Over the past century, the hydrological flow of the Everglades has been drained and rerouted in order to support coastal development and population growth in South Florida. The Central and South Florida Project (C\&SF) was authorized by Congress in 1948 as a massive engineering scheme commissioned to reroute water, from the annual rainfall that would normally flow throughout the Everglades, towards the east and west coasts of the state. The project included devising a system of about 1,800 miles of canals, 720 miles of levees, about 150 control structures (USACE and SFWSC, 1999), and 16 pumping stations to control and manage water levels throughout the system (Perry, 2004). The drainage and reconfiguration of the system provided an impetus for urban development along the eastern coast of the state and agricultural production.

Although the C\&SF paved the way for the expansion of both urban communities and certain industries in South Florida, the project created many adverse and unintended ecological consequences. As a result of the new management system, an estimated $70 \%$ of water is lost as it flows towards the estuaries on either side of the coasts, instead of 
flowing through the Everglades (2004), which equates to about 1.7 billion gallons of water lost a day (USACE and SFWSC, 1999). Additionally, the quality of the water flowing throughout the system is often saturated with contaminants, compromising the many other hydrological features within the Everglades system. The substantial alterations to the hydrologic regime of the Everglades has caused considerable decline in many native species of plants and animals, including the wading bird population which has declined around 90\% from 1931-1994 (Ogden 1994; Light and Dineen 1994; Loftus and Eklund 1994). In wake of all these unfavorable effects, the Everglades system is currently undergoing ecological restoration in order to restore the hydrological flow of the system, to some degree, through the Comprehensive Everglades Restoration Plan, or CERP. The main objectives of CERP are to protect the water quality and supply in South Florida by decreasing the amount of freshwater draining into the estuaries by re-directing the water back into the Everglades. While much research is focused on the science behind the Everglades restoration, little research effort is dedicated to the socioeconomic dimensions of these plans, especially with regards to the numerous and essential ecosystem services the Everglades provides to the residents of Florida.

Ecosystem services (ES) are defined as the benefits people receive from ecosystems (MA, 2005). The Everglades support a wide range of ES from the provisioning of drinking water for urban communities to recreational opportunities in Everglades National Park, the Water Conservation Areas, and Florida Bay. The Everglades' ability to deliver these benefits to society is directly linked to the health of the natural system. The provision of these ES is closely dependent on the ongoing efforts to restore the Everglades system (either the partial or full restoration of the hydrological 
flow of the Everglades will affect the ecosystem's ability to provide these services). The plans for restoration also result in ecological tradeoffs between ES, and social tradeoffs between accepting the consequences of ecological change on society and the regional economy. Potential tradeoffs of the aforementioned nature include possible tradeoffs between increased ecological benefits as a result of restoration at the expense of the reduction of agricultural land. Considering the urban development and population within South Florida, restoration cannot be obtained without certain gains and benefits towards society and the ecosystem. Hence, our current study seeks to assess how stakeholders value the ES provided by the Everglades to incorporate these stated preferences into environmental decision making for South Florida.

Several studies generated values for the benefits South Florida receives from the Everglades. A recent study commissioned by the Everglades Foundation estimated that the economic welfare generated by Everglades' restoration will yield about $\$ 46.5$ billion in net present value terms and range up to $\$ 123.9$ billion (McCormick et al., 2010), on the basis of on six different ES. The $\$ 46.5$ billion represents a 4:1 ratio of return on investment through CERP. However, opposition exists (Norrbin, 2011) as to the validity of this estimate and the methods used, as they may have resulted in overestimation. Prior to the current study, Milon et al., (1999) surveyed South Floridian households in an effort to gauge public preferences for Everglades Restoration, when the plans for restoration were in a draft stage. The study was designed to evaluate the public's willingness to pay (WTP) for restoration options, while weighing potential tradeoffs, in order to use these estimates to compare alternative restoration plans. Milon et al. (1999) employed the Multi-Attribute Utility Theory (MAUT) to a choice experiment to estimate values for 
partial and full restoration of the hydrological regime of certain areas of the SFWMD and certain species populations within the Everglades. Milon et al. (1999) produced various estimations of the net benefits for Everglades's restoration including one estimate of net WTP of $\$ 907.0$ million over 10 years. Milon et al., (1999) remains the leading social science study with respect to the Everglades, and as such is highly incorporated into the current study.

The current study aims to (1) replicate the same aspects of the Milon et al., (1999) study to generate new values for Everglades Restoration to evaluate whether or not the new values reflect temporal changes, and to (2) generate economic values for ecosystem services not considered in the Milon et al., (1999), to reflect the ecological and social tradeoffs inherent within CERP. The center-piece of the study is a choice experiment, a stated preference valuation method utilized in many studies to asses preferences for ecological attributes (Milon et al., 1999; Loomis et al., 2000; Westerberg et al., 2010; Johnston et al., 2011) A choice experiment, also known as a conjoint analysis, is widely accepted form of contingent valuation, in which a hypothetical market scenario is created for respondents to make a decision of how much they would be willing to pay while integrating multiple attributes within the decision. Within a choice experiment, the respondent will receive a choice card that contains various management plans with varying levels per attribute for which they must evaluate all of the options and indicate which plan they are most willing to pay for. In addition to the choice experiment, the respondents will also be asked how important each of the attributes were in their decision, to gain an understanding of which ecological or social attributes are preferred by the public. To elicit well-informed responses, two informational videos were produced 
and placed before the choice card in order to communicate information on the complexities of the Everglades. Additionally, two explanatory videos were produced and shown prior to the choice cards to further contextualize the choice cards and explain how to approach the cards before choosing a management plan.

In order to obtain the information for our study, we conducted a household online survey through the Qualtrics survey software. The survey contained 120 questions including the choice cards and an extensive demographic question section, and took approximately 30 minutes to complete. In the present study we include the responses from two distinct sample populations, including (1) the general public (Florida residents) and (2) salt-water anglers (people who obtained saltwater fishing licenses in Florida). The data obtained from the choice experiment serves as the basis for estimation of the monetary value of the ES provisioned by the Everglades. Considering that South Florida depends significantly on the services afforded by the Everglades, the analysis from this study will dispense vital information for decision makers in this region. 


\section{CHAPTER 2: LITERATURE REVIEW}

\subsection{The Everglades- The Past, The Present, and The Plans for Restoration}

\subsubsection{The Significance of the Everglades}

The Everglades is an expansive freshwater wetland system, which begins in Central Florida at the Kissimmee River and empties into Florida Bay. The Everglades encompasses over 10,000 sq. km (Wetzel et al., 2005), flowing like a "river of grass" to the southern end of the state (Douglas, 2007). Marjory Stoneman Douglas coined the term "river of grass" in 1947, when describing the slow-moving flow of water within the Everglades. Her phrase captured the grand natural landscapes of saw grass marshes, prairies, cypress swamps, and hardwood hammock ecosystems that are present throughout the Everglades. In describing the beauty of the Everglades, Douglas wrote...

"There are no other Everglades in the world. They are, they have always been, one of the unique regions of the earth, remote, never wholly known. Nothing anywhere else is like them; their vast glittering openness, wider than the enormous visible round of horizon, the racing free salt-ness and sweetness of their massive winds, under the dazzling blue heights of space" (2007, pg. 5)

As time elapsed and certain circumstances prevailed, the need to preserve these unique ecosystems with the Everglades became apparent. As such, the Everglades became a U.S. National Park in 1947. The Everglades is also recognized as a World Heritage Site, a RAMSAR Wetland of International Importance, and an International Biosphere Reserve, designating the Everglades as an ecosystem of both national and international 
significance. These designations were granted after significant alterations were made to the historic Everglades.

\subsubsection{The Central \& Southern Florida Flood Control Project and Its Effects}

The historic Everglades encompasses more than the Everglades National Park and Biscayne Bay, as it consists of the Greater Everglades ecosystem, which includes the Kissimmee-Okeechobee-Everglades watershed system (Light and Dineen, 1994). This watershed is approximately $28,205 \mathrm{~km}^{2}$, or $449 \mathrm{~km}$ north to south and $100 \mathrm{~km}$ east to west (1994) (See Figure 2.1). The Greater Everglades ecosystem once extended over an area of about 7, 242,048 $\mathrm{km}$ and has now been reduced to about half of its original size, as a result of drainage within the Everglades. As communities along the eastern coast of South Florida began to expand, these communities needed a mechanism for controlling flooding events, supplying water, and clearing land suitable for agriculture.

As such, drainage and flood control in the Everglades commenced in the late 1800s. However, the large scale change to the Everglades system occurred through the Central and Southern Florida (C\&SF) Flood Control Project in 1948 (Godfrey and Catton, 2011). The main objectives of the C\&SF project included developing a flood control project and providing a stable source of water to allow for urban expansion on the eastern coast of South Florida, while promoting the use of land for agricultural purposes by treating the Everglades as a single system (2011). The C\&SF Flood Control Project resulted in "over 1000 miles of canals, 720 miles of levees, 16 pumping stations, and about 200 control structures," (Perry, 2004, pg 186) in order to re-route the hydrological flow of the Everglades and drain the freshwater into estuaries towards the Atlantic Ocean 
and the Gulf of Mexico. The project created the conditions needed for South Floridian communities to flourish in population and economic growth, and for agricultural sectors like the sugar industry to expand.

Figure 2.1: A comparison of the Historic Everglades (left) and the Current Everglades (right)

Source:( Loucks, 2008)

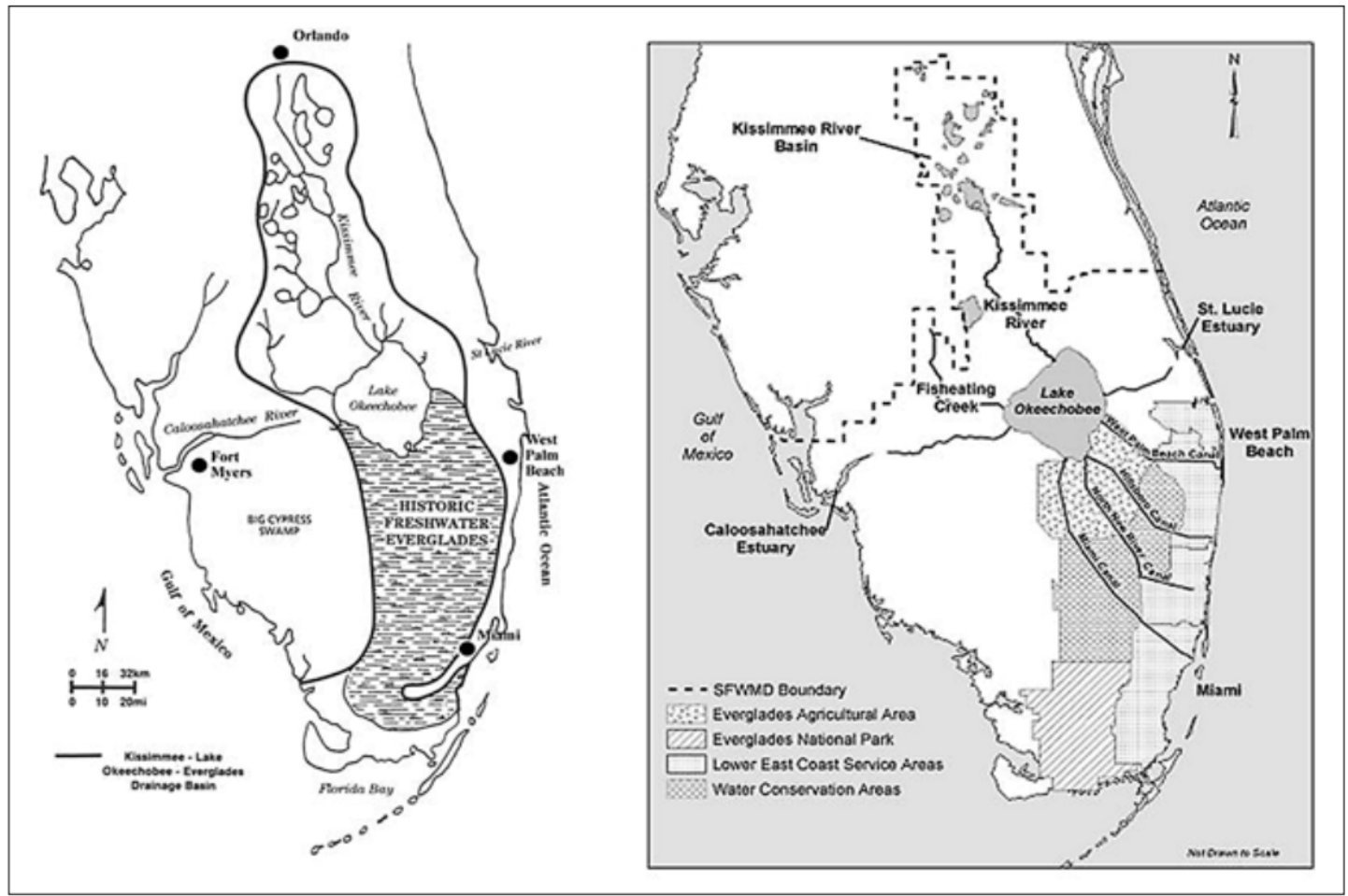

Specifically, the CS\&F created areas that the South Florida Water Management District (SFWMD) controls in order to manage water resources. These areas include the Everglades Agricultural Area (EAA), 3 Water Conservation Areas (WCAs), and various canals and other necessary infrastructure. (See Figure 2.2) 
Consequently, the CS\&F project created the circumstances that placed the Everglades ecosystem in the predicament that currently exists. The amount of freshwater flowing through the system has declined about $70 \%$ in comparison to the historic flow of the Everglades (Perry, 2003). Estimates place the rate of the water loss at approximately 3.8 billion liters of water a day (USACE and SFWMD, 1999).

Figure 2.2: Map of the water management areas governed by the SFWMD

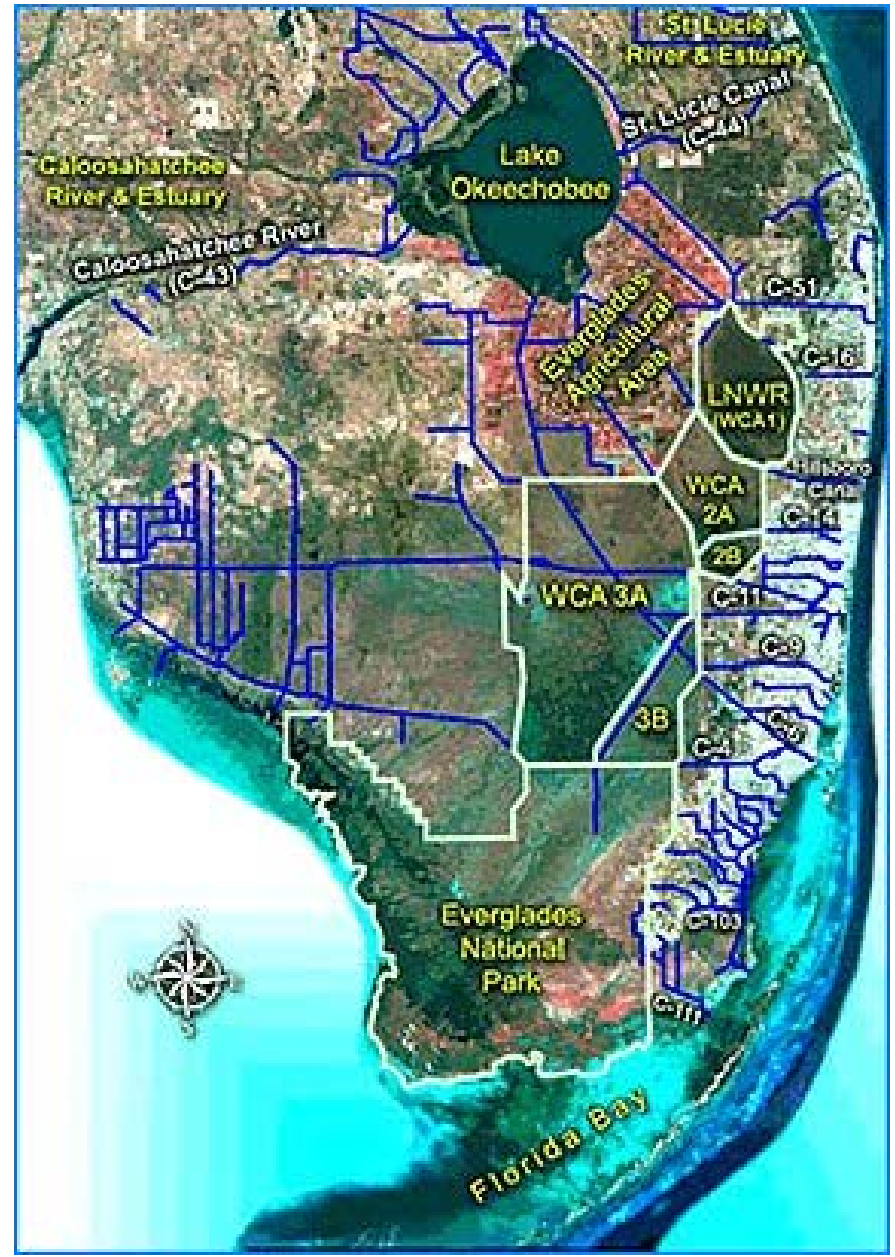

This significant loss of water resulted in the deterioration of ecosystems and habitats (Perry, 2003). Water drainage from the agricultural areas enriched with nitrogen and 
phosphorus (Craft, Vymazal, and Richardson, 1995; Davis, 1991; SFWMD, 1992) and pumped into the northern parts of the Everglades decreases the water quality and in some cases leads to eutrophication (Perry, 2003). Habitat fragmentation coupled with declining freshwater flow and water quality has also led to the severe reduction in many species within the Everglades, especially the wading bird population that has declined by $90 \%$ from 1931- 1994 (Ogden, 1994). Furthermore, 68 species are listed as endangered or threatened within the Everglades (Perry, 2003; Milon and Scrogin, 2006), including the Florida Panther and the West Indian Manatee. The reduction of freshwater flow through the system has also resulted in increased saltwater intrusion through the Biscayne Aquifer (Langevin, 2003). By the 1950s, the current water management system reduced the water table by 1 to $3 \mathrm{~m}$, thereby allowing saltwater to flow into the aquifer (Langevin, 2003). The saltwater intrusion is exacerbated by the reduction in freshwater flow, since the historic freshwater flow impeded the advancement of saltwater into the system. As relative sea levels continue to rise, saltwater will continue to intrude into the aquifer thereby endangering freshwater resources.

\subsubsection{The Comprehensive Everglades Restoration Project (CERP)}

In light of these pressing concerns, Congress authorized the Comprehensive Review Study (Restudy) of the Central \& Southern Florida Project in 1992, through the Water Resources Development Act (Voss, 2000). The Restudy examined the Everglades ecosystem in order to identify a conceptual solution to combat the deteriorating conditions of the Everglades through alterations to the current water management system, securing a stable water supply for the augmenting population of South Florida, and 
addressing the water quality issues for the future of various sectors (Voss, 2000; McLean, Ogden, and Williams, 2002). The Restudy concluded that the most effective way to accomplish these goals is to partially restore the Everglades in order to "...capture and store much of the water that is now lost to the ocean and gulf. The restoration will provide enough water in the future for both the ecosystem, as well as urban and agricultural users" (USACE and SFWMD, 1999, pg. 10).

Additionally, Governor Lawton Chiles established the Governor's Commission for Sustainable South Florida in 1994, which comprised about 50 individuals representing various stakeholder interests within the state, including business, environmental, and tribal leaders (Harwell et al., 1999). The Governor's Commission played a large role in consulting with scientific and technical advisory groups and incorporating various social values in order to shape priorities and objectives to guide the Restudy effort for the restoration of the Everglades system (Harwell et al., 1999). The Restudy resulted in the Comprehensive Everglades Restoration Plan (CERP), which outlines a plan to restore the hydrological flow of the Everglades to a more natural flow, thereby re-routing a large percentage of water that currently spills into the Atlantic Ocean and Gulf of Mexico back into the flow of the system. The plan proposes removing approximately 240 miles of dikes and levees (Voss, 2000; Carter, 2001) and other structures that currently hinder the flow. Of the re-directed water that returns to the system, $80 \%$ of the water will purportedly flow through the environment and the remaining $20 \%$ will be used to increase water stores for urban and agricultural users (Carter, 2001; Perry, 2003). 


\subsection{Ecosystem Services (ES)}

Despite the Everglades' compromised system, South Floridian communities rely on the benefits provided by the Everglades to sustain their livelihoods in a myriad of ways. These "benefits" are also called Ecosystem Services (ES), which “...represent the benefits human populations derive, directly or indirectly, from ecosystem functions" (Costanza et al., 1997, 253). In 1983, Ehrlich and Mooney published the first journal article using the term "ecosystem services" (Costanza and Kubiszewski, 2012), and since then the concept of ES has been expanded upon greatly, as have attempts to develop a definition. Fisher and Turner (2008) contend that distinctions should be made in defining services as "benefits." Using the work of Boyd and Banzhaf (2007), "a benefit is something that has an explicit impact on changes in human welfare," (Fisher and Turner, 2008, pg.1168) for which an example might be the recreation benefits that ecosystems provide. Fisher and Turner (2008) also suggest that ES can be both functions and processes within an ecosystem as long as there are human beneficiaries, which complements the views of both Daily (1997) and the Millennium Ecosystem Assessment (MA, 2005). The MA explicitly states for the purpose of discussion on ecosystem services, "goods," "services," and "cultural services" are all considered tangible “ecosystem services” (MA, 2005).

Furthermore, ecosystem structures support the provisioning of ecosystem services, as they represent the physical and biological composition and organization of an ecosystem (CAVSARTE, 2004). Both ecosystem functions and structure are necessary components in order to promote the full function of ecosystem services. These vital services provide myriad uses including commercial and recreational uses and promote 
aesthetic value. While ecosystems deliver services that have immense value to society, these services are considered non-market values because they are not factored into market costs (Daily, 1997). The study of ecosystem services and how they influence human welfare has gained popularity in recent years, due to a growing emphasis on the need to restore and maintain degraded ecosystems (Costanza et al., 1997; Daily, 1997). Since these systems promote the overall health of society and the environment, restoring function to imperiled ecosystems is in the best interests of many stakeholders, as in the case of Everglades's restoration.

The success of CERP will have a direct impact on the Everglades' ability to provide ecosystem services, and will improve its ability to provide these services in the future. These ecosystem services stem from the diversity of ecosystems present within the Everglades, including the extensive mangrove habitat and the saw grass marshes. These ES include but are not limited to a stable municipal water supply for Floridians, a water supply for agriculture, opportunities for recreational activities in the Everglades National Park and Florida Bay, a lucrative fishing industry in the littoral zone of Lake Okeechobee, and the recreational and ecological benefits from mangroves.

\subsubsection{Ecosystem Services within the Everglades System and their Respective Social} Dynamics

Water quality in estuaries: The St. Lucie and Caloosahatchee estuaries empty into the Atlantic Ocean and Gulf of Mexico, respectively. The St. Lucie Estuary (SLE) located on the eastern coast of Florida, is located within Martin and St. Lucie counties and historically drained into the Indian River Lagoon (Wilson et al. 2005; Doering 1996). Today, the C-44 canal drains into the SLE (Wilson et al., 2005) in order to divert 
freshwater from Lake Okeechobee into the Atlantic Ocean (Sime, 2005). Additionally, the C-23 and C-24 canals developed as part of the C \&SF Project also drain into the St. Lucie watershed (2005). The Caloosahatchee River drains into the Caloosahatchee estuary, located on the lower western coast of Florida within Lee and Charlotte counties. The estuary was initially a shallow river that originated from Lake Hicpochee (Barnes, 2005). Eventually, the river transformed into the C-43 canal draining freshwater from Lake Okeechobee into the Gulf of Mexico (Barnes, 2005). However, ecological stressors such as the modified freshwater flow and estuarine salinity (Sime, 2005; Barnes, 2005) coupled with anthropogenic stressors such as nutrient loading from urban agricultural practices have caused massive cyanobacterial blooms in both the SLE and Caloosahatchee estuaries (Williams et al., 2007; Burns, 2008). These algal blooms along the SLE are implicated in both ecological and human health risks (Williams et al., 2007), including a decrease in fish and oyster species (Sime, 2005), which threatens both commercial and sport fisheries. In the case of the Caloosahatchee estuary, recorded red tides blooms in the southwestern coast of Florida result in massive fish kills, the development of hypoxic zones, and the mortality of manatees, sea turtles, and birds (Yentsch et al., 2008).

Recreational Activities in Everglades National Park (ENP): The majestic and unique beauty of the Everglades National Park draws a significant number of tourists to South Florida each year. This national park provides countless recreational opportunities for tourists and residents of South Florida, including bird watching, boating, kayaking, fishing, wildlife viewing, camping, and hiking. In 2012, 1,141,906 visitors visited the 
ENP generating approximately $\$ 103$ million for the surrounding communities, which supported 1,402 local jobs (U.S. Department of the Interior, 2014). McCormick et al. (2010) estimated that as a result of Everglades Restoration, park visitation would generate around $\$ 1.3$ billion $(\$ 1,311,588,00)$ in net present value (NPV) over 50 years. The amount is postulated on the idea as restoration continues, the availability and frequency of recreational activities will subsequently increase.

Recreational Activities in Florida Bay- Florida Bay, located between the Florida Peninsula and the Florida Keys, is a subtropical estuarine system acknowledged for its biological productivity and marine nursery habitat (Homquist et al., 1989; Thayer \& Chester, 1989; Butler et al., 1995). Florida Bay provides valuable ecosystem services through its seagrass- dominated shallow waters (Butler et al.,1995, Hall et al. 1999). The seagrass, or Thalassia testudinum, provisions many ES, including supporting lucrative pink shrimp fisheries, (Fourqurean and Robblee, 1999; Hall et al., 1999) spiny lobster fisheries (Butler et al. 1995; Hall et al., 1999), and many other diverse fish and crustacean species. Seagrass beds also regulate nutrient cycling, alter water flow, and maintain an intricate food web (Orth et al., 2006) for many endangered species such as wading birds, manatees, and sea turtles (Hall et al., 1999). However, the altered Everglades system contributes to higher nutrient levels discharged into the Bay, leading to eutrophication and hypoxic waters, frequent algae blooms (Gilbert et al., 2004; Hall et al., 1999), and massive sea grass die offs (Butler et al., 1995; Hall et al., 1999; Fourqurean and Robblee, 1999). The anthropogenic change poses a substantial threat to the immensely beneficial sea grass beds and water quality in Florida Bay. Deteriorating water quality reduces the 
opportunity for recreational activities such as fishing, kayaking, swimming, and sailing in the bay.

\section{Commercial and Recreational Fishing Industry in Lake Okeechobee- Lake}

Okeechobee is a freshwater lake in Central Florida, which is approximately $730 \mathrm{~km}^{2}$ with an average depth of $2.7 \mathrm{~m}$ (Steinman, Havens, \& Hornung, 2002), and drains primarily into the Everglades Agricultural Area (EAA). The EAA consumes approximately 1.8 million acre-feet of water annually from the lake, valued at $\$ 500$ an acre-foot of water (Furse and Fox, 1994). Likewise, Lake Okeechobee supports lucrative commercial and recreational fishing industries for a variety of fish species in its littoral zone. The commercial fishing industry produces approximately $\$ 6.3$ million each year for catfish (Ameriurus sp. and Ictalurus sp.) and bream (luegill and redear sunfish) fisheries (Bell, 1987; Furse and Fox, 1994). As for the recreational fisheries, anglers fish largemouth bass, black crappie (Pomoxis nigromaculatus) and bream, which raises the value of these fisheries to $\$ 22.1$ million annually with an estimated $\$ 100$ million in asset value (Bell, 1987; Furse and Fox, 1994). As such, Lake Okeechobee provides immensely valuable services by supporting both commercial and recreational fisheries.

Benefits of Mangroves- The term "mangrove" refers to about 50 -75 woody species, describing two plant families (Barbier et al., 2011) and a tremendously beneficial coastal ecosystem. Mangrove ecosystems provide myriad ecosystem services including shoreline stabilization through erosion and flood control from storms (Sathirathai and Barbier, 2001; Barbier et al., 2011), through soil retention and wave and wind energy attenuation, 
respectively. Mangroves also provision water purification services, through nutrient and pollutant intake, and carbon sequestration services (Barbier et al., 2011). Additionally, the extensive root system within mangroves produces an excellent nursery habitat and breeding grounds for various species of fish, birds, mammals, shellfish, reptiles, and crustaceans (Alongi, 2008; Barbier et al., 2011), as well as raw materials such as wood and food for subsistence (Barbier et al., 2011). The recreational value and the resulting tourism that emanates from mangroves is an especially significant benefit for South Florida, as it promotes activities such as kayaking, canoeing, paddle-boarding, swimming, boating, and fishing.

However, the services mentioned above have purely anthropocentric benefits (thus deeming them ES). Yet mangroves are a crucial ecosystem in terms of its high ecological connection to both sea grass beds and coral reef systems. These three coastal ecosystems work in conjunction to provide fundamental coastal functions, such as migratory habitats for various marine species during ontogenic periods of their development (Mumby et al., 2004). Also, the mangroves in the Everglades ecotone region provide various services such as the regulation of nutrient transport into coastal waters (Chen and Twilley, 1999; Rivera-Monroy et al, 2011), which are necessary for the proliferation of both sea grass and coral reefs. Therefore, the loss of mangroves would have detrimental impacts on the ability of both seagrass and coral reef systems to biologically support one another (Mumby et al., 2004), and this connectivity should be acknowledged in any discussion of the value of mangrove ecosystem services. As such, mangroves have immense value globally, and locally in South Florida. Recent estimates of the total area of mangroves in the Everglades National Park place the acreage at 
144,447 ha (Rivera-Monroy et al., 2011), while recent valuation efforts have estimated the economic worth of mangroves at 200,000-900,000 USD ha ${ }^{-1}$ (UNEP- WCMC, 2006; Alongi, 2008).

\subsection{Economic Valuation of Ecosystem Services}

The aforementioned ES provided by the Everglades are immensely valuable, but oftentimes this value is not conveyed effectively to the general public, stakeholders, and regional decision makers when the value is expressed through qualitative means. As the interest in understanding the benefits conferred by ecosystems services has grown, the use of valuation methods in providing quantitative estimates of worth for ecosystem services has also risen. Economic valuation studies for ecosystem services have gained popularity as they draw conclusions about the overall contributions ecosystems impart on human society (UNEP, 2005). In fact, estimates place the total value of ecosystems services, globally, at $\$ 125$ trillion per year in 2011 (Costanza et al., 2014). The estimated value does not represent an exchange value, but instead represents an assessment on a use or non-use value that would otherwise be difficult to comprehend (Costanza et al., 2014). This form of quantitative assessment provides a mechanism which stakeholders can accurately gauge and appropriately weigh the tangible value of ES.

With regards to South Florida, few attempts have been made to generate values

for the ES provided by the Everglades with the exception of McCormick et al. (2010) and Milon et al. (1999). In the most recent report, McCormick et al. (2010) estimated the value of 6 different ecosystem services including groundwater purification, park visitation, open space, fishing, habitat for wildlife, and increased property values 
contingent on Everglades Restoration. Currently, the efforts set forth by CERP represent an $\$ 11.9$ billion investment. McCormick et al. (2010) estimated that the economic welfare generated by Everglades' restoration will yield about $\$ 46.5$ billion in net present value terms and range up to $\$ 123.9$ billion, generating a benefit cost ratio of $\$ 4$ generated for every \$1 spent. Figure 2.3 details a breakdown of the value of each ES included within the McCormick et al. (2010) report.

Figure 2.3: Summary of ES Valuation of Everglades Restoration from McCormick et al.

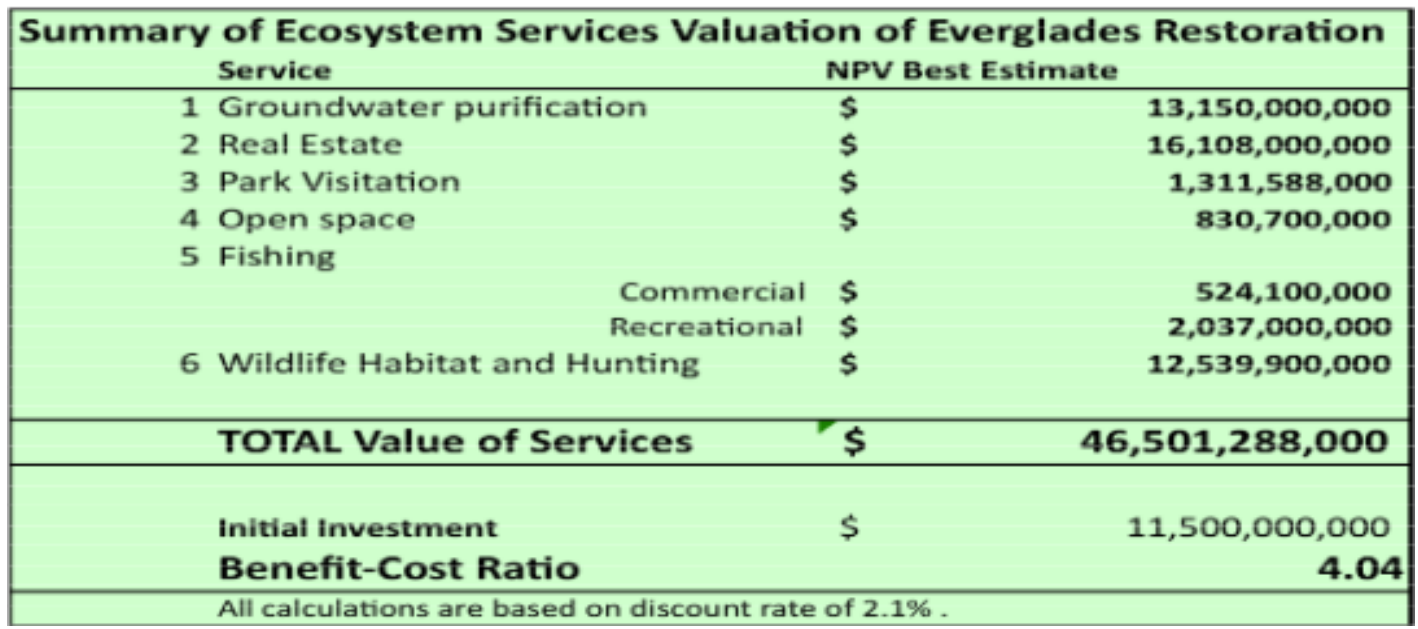

While economic valuation of ecosystem services presents a unique opportunity to provide a quantitative estimate of its economic benefits, the process of arriving at such a figure is quite nuanced. Fundamental questions exist with regards to the methods employed that can accurately derive quantitative values for ecosystem services (Daily, 1997). Numerous studies (Serafy, 1998; Loomis et al., 2000) argue that the methods used in valuation may lend itself to overestimation of services, since many services cannot often be explicitly valued separately. Loomis et al. (2000) points out that with certain 
methods of economic valuation, ecosystem services may be overestimated from either two -ten times more than they are worth. Norrbin (2011) reviewed the methods used to estimate groundwater purification, increased property values, and wildlife habitat in the McCormick et al. (2010) study, since these services accounted for $90 \%$ of the estimated increase in economic welfare. Norrbin's review determined “...in many instances chosen assumptions and models that are not appropriate estimates of the expected outcomes of the Everglades restoration," and therefore the expected gains are much lower than estimated in the report (2011, pg. 11). Since most ecosystems provide more than one service and the inherent ecological connectivity of ecosystems is necessary for certain ecosystem functions, independent valuation of services and then subsequent aggregation of these sums will likely result in a "double counting" of services.

\subsubsection{Stated Preference Methods}

In light of possible overestimation of the value of ES, stated preferences methods emerged as a way to lessen this possibility as they represent values stemming from an expressed value by stakeholders. Stated preferences (SP) methods of valuation are commonly used in valuation of ecosystem services, especially discrete choice experiments. The premise of discrete choice experiments involves designing a choice card, which contains various options (i.e., choices between restoration plans) each containing varying levels within multiple attributes (CAVSARTE, 2004; Longland et al., 2008), for which respondents indicate how much they would be willing to pay for a specific option based on the provided values. The fundamental idea prefacing choice experiments rests on creating a hypothetical market scenario, which would evoke 
individual's preferences through choosing between alternatives (Carlsson, Frykblom, \& Liljenstolpe, 2003; Shoyama et al. 2013). The decision making process within a choice experiment simulates a multifaceted, yet seemingly ordinary decision individuals must commit to when exercising their purchasing power. Discrete choice experiments evolved from a combination of various theories across a few disciplines, which include information integration theory and axiomatic conjoint measurement from psychology, random utility theory from economics, and optimal experimental design and discrete multivariate models from statistics (Hoyos, 2010; Lancsar and Louviere, 2008).

Before being applied to valuation of ES studies, discrete choice experiments were used extensively within marketing research to assess revealed consumer preferences measured by choices made following the presentation of multi-attribute choice sets to respondents (Adamowicz et al., 1998). As a result of the multi-attributed orientation of a choice card, the method is also useful in assessing the tradeoffs respondents are willing to make between attributes (Boyer and Polansky, 2004), or more specifically, between biodiversity conservation and various social and economic welfare components (Shoyama et al., 2013). Once the stated preferences are obtained, usually through embedding the choice experiment within a survey, econometric analysis taken from the random utility model produces the estimated utility values (Shoyama et al., 2013). The random utility theory serves as the theoretical foundation for incorporating behavior and decisions displayed through the choice experiment into economic valuation, through integration of a deterministic and an error component within the utility of a choice (Birol, Koundouri, \& Kountouris, 2009). 
Myriad studies (Milon et al., 1999; Shrestha and Alavalapati, 2004; Westerberg et al., 2010, Johnston et al., 2011; Shoyama et al., 2013) successfully employed this methodology in order to obtain economic values for various environmental services and potential tradeoffs. While the application of discrete choice experiments are favored for valuation of environmental goods and services, the process lends itself to uninformed decision making as a consequence of low scientific awareness amongst the general public. As such, "ecosystem service indicators" are developed within these experiments to convey ecological facts regarding system dynamics in an accurate, yet understandable manner for a non-scientific audience. However, “...challenges related to the characterization of ecologically meaningful outcomes in SP surveys are exacerbated by a low level of ecological understanding among the public" (Johnston et al., 2012 need pg \#). Developing these indicators requires collaboration between ecologists and social scientists in order to hone in on the most relevant and salient ecological details without burdening the respondents with extraneous scientific facts. The iterative process enhances content validity (Johnston et al., 2012) within the choice experiment with the eventual goal of producing a more informed WTP decision.

The need for estimation of the intrinsic worth and the direct and indirect benefits provisioned by the Everglades is predicated on the idea that potential benefits or losses gained from restoration extend beyond a single decision making individual. Markets are ineffective at efficiently allocating public resources, as these goods and services will generally have ill-defined property rights (Haab and McConnell, 2002) thereby discouraging the internalization of any positive or negative externalities. Therefore, restoration of environmental goods and services will require public action, as these 
resources add tremendous value to the continued functionality and welfare of the regions that depend on these goods and services. In the absence of determined property rights, the process by which values of worth are generated and tradeoffs are assessed should consider the views and preferences of many individuals for the advancement of ecological and public welfare. As such, public preferences and support on certain restoration components are critical when addressing regional long -term plans for Everglades Restoration and the resiliency of South Florida, especially in light of projected population increases in the region.

According to Table 2.1, the total population for South Florida counties will increase from 5,730, 701 people in 2012 to 7,039,053 people by 2040, representing a $22.84 \%$ increase in population over 28 years. As such, the ES imparted from the Greater Everglades system must accommodate the projected increase in population. When considering how restoration may affect many facets of life in South Florida, evaluating how the Everglades system will accommodate this population growth is especially important.

Table 2.1 Population Projections for South Florida 2012- 2040

\begin{tabular}{lrrrr}
\hline \multicolumn{5}{c}{ Population Projections for South Florida } \\
\hline County & $\mathbf{2 0 1 2}$ & $\mathbf{2 0 2 0}$ & $\mathbf{2 0 3 0}$ & $\mathbf{2 0 4 0}$ \\
\hline Miami-Dade & $2,551,290$ & $2,761,156$ & $3,009,309$ & $3,204,915$ \\
Broward & $1,771,099$ & $1,850,809$ & $1,948,726$ & $2,033,471$ \\
Palm- Beach & $1,335,415$ & $1,465,309$ & $1,616,867$ & $1,733,331$ \\
Monroe & 72,897 & 71,050 & 68,903 & 67,336
\end{tabular}




\begin{tabular}{lllll}
\hline Total & $5,730,701$ & $6,148,324$ & $6,643,805$ & $7,039,053$
\end{tabular}

Source: (OEDR, 2014)

While the Everglades system imparts the aforementioned ES, and many unmentioned services, on South Floridian communities, CERP will have an effect on the provision of each of these services, and some of these effects may not be welcomed. Since CERP operates on treating the restoration of the Everglades a whole system, tradeoffs are an inherent result of the restoration process, especially when considering societal priorities such as reducing urban flood risk, possible restrictions on urban expansion, increasing municipal water supply, and securing agricultural water demands. Therefore, the need for a social science study to assess the public's preferences and priorities for Everglades Restoration and preferred ecosystem benefits is a necessary component to inform decision makers and resource managers in the region.

\subsection{Milon et al. (1999) Study Review}

\subsubsection{Milon et al. (1999) Study Methods}

While much research is focused on the science behind the Everglades restoration, little research effort is dedicated to the socioeconomic dimensions of these plans. Milon et al., (1999) conducted a study aimed at assessing public preferences for Everglades Restoration, when the plans for CERP were under development. As such, the Milon et al. (1999) study played a vital role in shaping our current study. The premise of the Milon et al. (1999) study focused on evaluating the public's willingness to pay (WTP) for restoration options and using these estimates to compare alternative restoration plans, 
while measuring the economic benefits produced from choices between ecological endpoints (Milon et al., 1999). An ecological endpoint in this study is described "as those characteristics of the ecosystem that if changed, would constitute a change in the health of the ecosystem" (Harwell and Long, 1992; Harwell et al., 1992; Milon et al., 1999), and can be described as attributes. Specifically, the study observed how changes in the hydrological flow of the Everglades, and how increases in various populations of species by habitat type would affect stated preferences. Furthermore, socio-economic attributes such as restrictions on water usage and farmland acreage conversion were included to incorporate the idea of social and ecological tradeoffs. To observe these changes, Milon et al., (1999) organized these ideas into three separate attribute groups: hydrologic model attributes, species model attributes, and socio-economic attributes. These three attribute groups were then incorporated into a choice experiment for which respondents would choose which restoration plan they would be most willing to pay for.

The restoration plans within the individual choice sets represented either partial or full Everglades's restoration, along with partial or full wildlife population restoration based on habitat type. Within the hydrologic model attributes, individuals were asked to determine how much they would be willing to pay for a certain "percentage of time that water levels and timing would be similar to the historic, predrainage conditions" of Lake Okeechobee. In both the Everglades Water Conservation Areas and Everglades National Park and Florida Bay, respondents were asked how much they would be willing to pay for a certain percentage of area that "has water levels and similar to historic, predrainage conditions" (Milon et al., 1999) (see Figure 2.4 for the specific percentages used, as well of descriptions used for each of the geographic features mentioned above). As for the 
species model attributes, participants were asked to evaluate their WTP for different percentages of historic, predrainage population levels of wetland, dry land, and FloridaBay- dependent species (1999) (see Figure 2.4 for the specific percentages used, as well of descriptions used for each of the habitat- based species populations mentioned above) Finally, the socio-economic attributes of restrictions on household water use, farmland acreage reduction, and annual cost per household (payment for the choice of restoration plan), were incorporated into each individual choice set regardless of the presence of the hydrological model or species model attributes, in order to make participants consider a tradeoff situation between desired ecological and social attributes (see Figure 2.4 for the specific percentages used, as well as descriptions used for each of the socio-economic attributes mentioned above).

In order to elicit stated preferences for these attribute groups, the Milon et al. (1999) study applied the Multi Attribute Utility Theory (MAUT) to a choice experiment. The MAUT framework was used to analyze data collected through the choice experiment to account for tradeoffs corresponding to various restoration plans, and to estimate economic values for the changes in varying levels within the attributes (1999). In order to collect a representative sample 
Table 2.2: List of Ecological and Social Attributes Considered in Milon et al. (1999)

Attribute Names, Descriptions and Altemative Levels for Multiattribute Analysis of Everglades Restoration.

\begin{tabular}{|c|c|c|}
\hline & Attributes/Description & $\begin{array}{c}\text { Attribute } \\
\text { Levels }\end{array}$ \\
\hline \multirow{9}{*}{$\begin{array}{l}\text { Hydrologic } \\
\text { Model } \\
\text { Attributes }\end{array}$} & Lake Okeechobee. Percentage of time that water levels and timing in Lake Okeechobee are & $60 \% *$ \\
\hline & similar to historic, predrainage conditions & $75 \%$ \\
\hline & & $90 \%$ \\
\hline & Everglades Water Conservation Areas. Percentage of area in the Everglades Water Conservation & $50 \% *$ \\
\hline & Area having water levels and timing similar to historic, predrainage conditions & $75 \%$ \\
\hline & & $90 \%$ \\
\hline & Everglades National Park and Florida Bay. Percentage of the area in Everglades National Park & $50 \% *$ \\
\hline & and Florida Bay that has water levels and timing similar to historic, predrainage conditions & $75 \%$ \\
\hline & & $90 \%$ \\
\hline \multirow{9}{*}{$\begin{array}{l}\text { Species } \\
\text { Model } \\
\text { Attributes }\end{array}$} & Wetland Dependent Species. Percentage of historic, predrainage population levels of wetland & $20 \% *$ \\
\hline & dependent species such as wading birds and alligators & $50 \%$ \\
\hline & & $80 \%$ \\
\hline & Dry Land Dependent Species. Percentage of historic, predrainage population levels of dry land & $50 \% *$ \\
\hline & dependent species such as deer, hawks and songbirds & $60 \%$ \\
\hline & & $70 \%$ \\
\hline & Florida Bay Dependent Species. Percentage of historic, predrainage population levels of Florida & $60 \% *$ \\
\hline & Bay dependent species such as pink shrimp, mullet and sea trout & $75 \%$ \\
\hline & & $90 \%$ \\
\hline \multirow{9}{*}{$\begin{array}{l}\text { Socio- } \\
\text { Economic } \\
\text { Attributes } \\
\text { (both } \\
\text { Hydrologic } \\
\text { and Species } \\
\text { Models) }\end{array}$} & Annual cost per household. Additional annual cost per household for water utilities & $\$ 0^{*}$ \\
\hline & & $\$ 25$ \\
\hline & & $\$ 50$ \\
\hline & Restrictions on Household Water Use. Number of days per week that outdoor water use & $3 / 10 \% *$ \\
\hline & allowed during dry years, and percentage reduction in indoor water use & $2 / 25 \%$ \\
\hline & & $1 / 40 \%$ \\
\hline & Farm land Reduction. Area (acres) of farm land that would be reduced in the Everglades & $0^{*}$ \\
\hline & Agricultural Area and western portions of Palm Beach, Broward and Dade counties & 100,000 \\
\hline & & 200,000 \\
\hline
\end{tabular}

* Denotes baseline condition currently

of choice cards with changes in the attribute levels, 27 choice cards were created. These choice cards were randomized and embedded within a questionnaire taken by 480 randomly selected South Florida households through in-person interviews. Respondents were shown an 11-minute informational video on the different aspects of Everglades Restoration, prior to answering choice cards (for example, the significance of hydrological flow in determining species habitat and water availability and quality, etc.). The purpose of these videos was to familiarize respondents with the complexities of the Everglades ecosystem, the current issues within the present water management system, and the consequences of controlling water flow in the Everglades. Afterwards, the 
respondents would be able to make more informed decisions towards the choice card and questionnaire, in the event the respondents were not acquainted with the subject matter.

\subsubsection{Milon et al. (1999) Study Results and Conclusions}

The estimates generated from the responses within the choice cards for various plans are listed below in Table 2.2, along with the plan description, percentage of respondents who favored that plan, and net willingness to pay for the respective plan. For the restoration plans that included full hydrological restoration and species restoration, net willingness to pay amounted to $\$ 59$ and $\$ 70$ annually, respectively. However, respondents did not support hypothetical

Table 2.3: WTP Values for Selected Restoration Plans from Milon et al (1999)

\begin{tabular}{|c|c|c|}
\hline Plan Description & $\begin{array}{l}\text { Percent of } \\
\text { Respondents } \\
\text { in Favor }\end{array}$ & $\begin{array}{c}\text { Net } \\
\text { Willingness } \\
\text { to Pay }\end{array}$ \\
\hline \multicolumn{3}{|c|}{ Hydrological Multiattribute Model } \\
\hline Partial Hydrologic Restoration without Costs & 71.7 & $\$ 34.32$ \\
\hline Full Hydrologic Restoration without Costs & 71.7 & $\$ 58.79$ \\
\hline Partial Hydrologic Restoration with Minimized Costs & 44.3 & $\$ 9.32$ \\
\hline Full Hydrologic Restoration with Minimized Costs & 54.3 & $\$ 15.60$ \\
\hline Full Hydrologic Restoration with Full Costs & 31.1 & $-\$ 61.09$ \\
\hline \multicolumn{3}{|c|}{ Species Multiattribute Model } \\
\hline Partial Wetland Wildlife Restoration without Costs & 92.7 & $\$ 34.93$ \\
\hline Full Wetland Wildlife Restoration without Costs & 92.7 & $\$ 69.86$ \\
\hline Partial Dryland Wildlife Restoration without Costs & 17.9 & $-\$ 11.95$ \\
\hline Full Dryland Wildlife Restoration without Costs & 17.9 & $-\$ 23.90$ \\
\hline
\end{tabular}

restoration plans that levied high costs on Floridians. These plans were not met with support, especially when coupled with farmland reductions of 100,000 acres or more or severe water restrictions. In terms of aggregate benefits, the net WTP of full hydrological restoration without costs produced a value of $\$ 3.42$ billion over 10 years, and full 
wetland/estuarine species restoration without costs amounted to $\$ 4.02$ billion over the same time period. Furthermore, aggregate benefits for a more practical alternative restoration plan that included full hydrological restoration of Everglades, 100,000 acres farmland reduction, and moderate water restrictions with annual costs of $\$ 25$ per household produced an estimate of net WTP of $\$ 907.0$ million over 10 years. The estimates generated in this study represent a comprehensive endeavor to engage the general public and ascertain their preferences for one of the largest and ongoing ecological restoration projects. Milon et al. (1999) remains one of the leading social sciences studies for valuating benefits from the Everglades and its methodology is heavily incorporated into the current study 


\section{CHAPTER 3: METHODOLOGY}

\subsection{The Present Study}

\subsubsection{Attribute Selection}

The current study seeks to valuate some of the ecosystem services provided by the Everglades and assess the public's preferences for the tradeoffs associated with the system's restoration. The survey will feature a choice experiment similar to the experiments conducted in Milon et al. (1999), Westerberg et al. (2010), Johnston et al. (2011), and Shoyama et al. (2013) by which respondents chose between various restoration plans that contain a corresponding provision of specific ES under that plan. The current study also borrows heavily from the Milon et al. (1999) study, as one of the primary objectives of the study includes replicating the choice experiment in order to assess whether the estimates produced in the earlier study changed temporally.

As such, the Milon et al. (1999) study serves as benchmark for which we intend to compare the WTP values generated within the current study to the values generated fifteen years ago. Generally speaking, Brouwer and Bateman (2005) found that temporal stability of estimates produced from contingent valuation methods (CVM) show statistically significant decreases in value over extended periods of time. However, estimates may also change in the other direction as well depending on how ecosystem services are valued and preferred as time elapses. Since the Milon et al. (1999) study represents the first study to produce estimates for South Florida's residents WTP for Everglades Restoration, we intend to test the temporal stability of these values over a 15year period. Furthermore, the Milon et al. (1999) study only considered a few elements

(the hydrologic and species model) of Everglades Restoration and a few socio-economic 
considerations (restrictions on water use and farmland reduction) and price (water utility increases) See Table 3.1 for more descriptions. The current study seeks to estimate new values for previously unconsidered ecological and social attributes affected by CERP. These attributes are listed in Table 3.2 are separated by categories:

Table 3.1: Milon et al (1999) Attributes Included in the Present Study

\begin{tabular}{ll}
$\begin{array}{l}\text { Hydrological Model Attributes - } \\
\text { Adapted from Milon et al. (1999) }\end{array}$ & $\begin{array}{l}\text { Species Model Attributes - Adapted } \\
\text { from Milon et al. (1999) }\end{array}$ \\
\hline Lake Okeechobee & Wetland Species \\
Water Conservation Areas & Dryland Species \\
Everglades National Park & Florida Bay Species \\
Farmland Acreage & Farmland Acreage \\
Restrictions on Water Use & Restrictions on Water Use \\
\hline
\end{tabular}

Table 3.2: Ecological and Social Attributes Included in the Present Study Not Previously Considered in the Milon et al (1999)

\section{Ecological Attributes \\ Social Attributes}

Water Levels in Lake Okeechobee

Water Quality In Estuaries

Recreation in Everglades National Park

Recreation in Florida Bay

Inland Mangrove Expansion
Agricultural Water Demand

Municipal Water Demand

Urban Flood Risk

Restrictions on Urban Expansion

The current study has 3 primary objectives:

1. Replicate some components of the Milon et al. (1999) study to update values for the hydrological, species, and socio-economic attributes relating to Everglades Restoration.

2. To develop a survey to generate values for a new set of attributes that were not considered in the Milon et al. (1999) study. 
3. To generate WTP values for the ecological and social attributes to inform decision making in South Florida. The data will be used to investigate how public preferences and willingness to pay (WTP) for ecosystem services vary over time and across socioeconomic \& ethno-demographic categories in South Florida. We will also estimate variations in willingness to pay (WTP) based on marginal changes in the specific ecosystem service attributes listed in the choice experiment.

\subsubsection{South Florida Water, Sustainability, Climate Project (SFWSC) and Motivation}

The attributes selected for inclusion in the study were developed largely in consideration of the goals of the South Florida Water, Sustainability, and Climate (SFWSC) Project (see http://sfwsc.fiu.edu/ for more information). This study is an integral component of this comprehensive research project focused on understanding how water resources in South Florida would be affected by future climatic, social, and environmental changes. An essential piece of this project includes assessing how public opinion and engagement could enable economic valuations for ecosystem services and improves societal understanding for risk management and environmental decisionmaking. Hence, the current study is conducted as a way to achieve the goal of economic valuation for ES within South Florida. The study is motivated by a few key understandings:

1. The provision of ES is closely dependent on the ongoing efforts to restore the Everglades system (either the partial or full restoration of the hydrological flow of the Everglades will affect the ecosystem's ability to provide these services). 
2. Estimating an economic value for these benefits will facilitate better decision making for ecosystem management.

3. Certain tradeoffs between ES are inherent in restoration plans. Assessing the value and preferences for these tradeoffs is critical for comprehensive understanding of the public's preferences for Everglades Restoration.

4. Values would change over time as do ES because of the changes in climate, ecosystem health and demographic and economic conditions.

\subsubsection{Ecological Attributes}

The ecological attributes chosen for this study include a variety of ES, which provide many benefits for South Florida, but will also be affected by Everglades Restoration in some manner. These attributes include fish abundance in Lake Okeechobee, water quality in the estuaries, recreation in the Everglades National Park and Florida Bay, and mangrove expansion. Table 3.3 provides a shortened description of each of the new attributes. See Figure 2.4 for a description of the attributes adapted from the Milon et al. (1999) study.

Fish abundance in Lake Okeechobee: The littoral zone of Lake Okeechobee heavily supports both the lucrative commercial and recreational fishing industry within the lake. However, the increases in storage as a result of Everglades Restoration may negatively impact these fisheries. The storage of additional water in the lake may submerge the productive littoral zone, decreasing fish abundance in this area. 
Water quality in the Estuaries: The current water quality of rivers and canals that drain into the estuaries, which then empties into both the Gulf of Mexico and the Atlantic Ocean through tidal exchanges contains nutrients that lead to eutrophication and massive algae blooms. These cyanobacterial blooms negatively affect the residential communities along these estuaries by lowering their property values. Restoration within the Everglades would allow for the discharge of less water and less nutrients into these estuaries thereby reducing the frequency of cyanobacterial blooms.

Recreation in the Everglades National Park: As a park of international and national significance, the Everglades National Park provides many opportunities for recreation, including wildlife viewing, boating and fishing opportunities, bird watching, hiking, camping and more. These recreational values have both an inherent and an economic value as a valuable environmental service, and restoration will allow for the increase in access to these activities since the conditions in the ENP will improve as a result of restoration.

Recreation in Florida Bay: Located at the tip of the southern end of the state, Florida Bay also provides a vast body of water for many recreational activities. These activities include kayaking, snorkeling, paddle boarding, free diving, boating, fishing and much more. Many of the species that are fished with the Bay include lucrative species such as the Key West Pink Shrimp and lobster species. Everglades Restoration will allow for more access to participate in these recreational activities, through improvements in the conditions in the Bay. 
Inland Mangrove Expansion: As sea levels continue to rise, saltwater will continue to expand into Florida Bay prompting the migration of mangrove habitats. However, as restoration commences and the freshwater flow increases throughout the Greater Everglades system, the force of this freshwater will "push" out the intruding saltwater. Consequently, the influx of freshwater draining through Florida Bay will maintain the mangrove habitat by holding back rising sea levels.

\subsubsection{Social Attributes}

Agricultural Water Demand: The agriculture industry benefitted greatly from the C\& SF Flood Control project, as the project allowed for drainage of fertile wetlands needed to spur agricultural growth. Current practices in the agriculture industry demand a significant amount of water. As the agriculture industry continues to proliferate, water will become scarce unless restoration begins to provide additional freshwater for distribution throughout the region.

Municipal Water Demand: In the coming years, the availability of high quality water demands will vary depending on climatic conditions and whether or not Everglades Restoration ensues. As the population of South Florida continues to grow, more water will be needed to support this growth and municipal uses as well as adjust for possible climatic variation.

Urban Flood Risk: While the expansion of freshwater flow will greatly increase the availability of water for both agricultural and municipal supply, it will also increase the risk of urban flooding. In order to accommodate the spread of water throughout the 
Everglades, land will need to be converted back into wetlands. However, this land conversion may not suffice and more frequent inland flooding may occur.

Restrictions on Urban Expansion: As the population of South Florida continues to grow, real estate development, including commercial development, will also continue grow in order to adapt to the changing social landscape. However, if restoration goes into effect, further expansion westward will be unlikely, as result of the accretion of freshwater. Therefore Everglades Restoration will foster denser development in South Florida to accommodate a growing population

Table 3.3: Short Descriptions of the New Attributes for Modified Choice Card

\begin{tabular}{|c|c|c|}
\hline $\begin{array}{l}\text { Attribute } \\
\text { Name }\end{array}$ & Attribute Description & Levels \\
\hline $\begin{array}{l}\text { Water Levels in } \\
\text { Lake } \\
\text { Okeechobee }\end{array}$ & $\begin{array}{l}\text { Changes in water levels as a result of increased flow } \\
\text { restoration may decrease fish abundance in littoral zone } \\
\text { of the lake }\end{array}$ & $\begin{array}{l}\text { No change, } 20 \%, 40 \% \text {, } \\
60 \% \text {, and } 80 \% \text { decrease in } \\
\text { fish abundance }\end{array}$ \\
\hline $\begin{array}{l}\text { Agricultural } \\
\text { Water Demands }\end{array}$ & $\begin{array}{l}\text { Agricultural production requires a substantial amount of } \\
\text { water. Water supply will need to keep up with demand in } \\
\text { this sector. }\end{array}$ & $\begin{array}{l}\text { No unmet demands, } \\
5 \% 10 \%, 20 \% \text {, and } 30 \% \\
\text { demands are not met }\end{array}$ \\
\hline $\begin{array}{l}\text { Municipal } \\
\text { Water Supply }\end{array}$ & $\begin{array}{l}\text { As the population in South Florida increases, water } \\
\text { supply for municipal use will have to accommodate for } \\
\text { this population growth in midst of ecological stressors }\end{array}$ & $\begin{array}{l}15 \% \text { and } 10 \% \text { decrease, } \\
10 \% \text { and } 5 \% \text { increase and } \\
\text { no unmet demands }\end{array}$ \\
\hline $\begin{array}{l}\text { Recreation in } \\
\text { Everglades } \\
\text { National Park }\end{array}$ & $\begin{array}{l}\text { The Everglades National Park allows for the opportunity } \\
\text { for many recreational activities. Restoration will allow } \\
\text { for increased access to these activities. }\end{array}$ & $\begin{array}{l}10 \% \text { and } 20 \% \\
\text { decrease, } 10 \%, 20 \%, 30 \% \\
\text { or } 40 \% \text { increase in access }\end{array}$ \\
\hline $\begin{array}{l}\text { Recreation in } \\
\text { Florida Bay }\end{array}$ & $\begin{array}{l}\text { Florida Bay provides a many opportunities for lucrative } \\
\text { recreational activities including fishing and snorkeling. } \\
\text { Restoration will improve conditions in the Bay allowing } \\
\text { for access to more recreational activities. }\end{array}$ & $\begin{array}{l}10 \% \text { and } 20 \% \text { decrease, } \\
5 \%, 10 \%, 20 \% \text { and } 30 \% \\
\text { increase in access }\end{array}$ \\
\hline $\begin{array}{l}\text { Inland } \\
\text { Mangrove } \\
\text { Expansion }\end{array}$ & $\begin{array}{l}\text { As a result of the influx of freshwater from Everglades } \\
\text { Restoration, mangrove habitats may remain in their } \\
\text { current location, as opposed to migrating in light of } \\
\text { increased salinity. }\end{array}$ & $\begin{array}{l}5 \% \text { and } 10 \% \text { decrease, } \\
5 \%, 10 \%, 20 \% \text {, and } 30 \% \\
\text { increase }\end{array}$ \\
\hline $\begin{array}{l}\text { Restrictions on } \\
\text { Urban } \\
\text { Expansion }\end{array}$ & $\begin{array}{l}\text { In order to accommodate the increase in freshwater } \\
\text { flow, urban communities may not be able to expand } \\
\text { westward, even though populations in South Florida are } \\
\text { expected to rise. }\end{array}$ & $\begin{array}{l}\text { Current rate of expansion, } \\
\text { low rate of expansion, and } \\
\text { no further expansion }\end{array}$ \\
\hline $\begin{array}{l}\text { Water Quality } \\
\text { of Estuaries }\end{array}$ & $\begin{array}{l}\text { Increased flow through the Everglades will significantly } \\
\text { enhance the water quality in estuaries resulting in a } \\
\text { decrease in cyanobacterial blooms. }\end{array}$ & $\begin{array}{l}\text { Poor water quality occurs } \\
\text { every year, } \\
\text { every } 2,5,10,20 \text {, and } 30\end{array}$ \\
\hline
\end{tabular}




\begin{tabular}{|lll|}
\hline & & years \\
\hline & $\begin{array}{l}\text { As the freshwater flow increase in the Everglades and } \\
\text { through the estuaries, the rate of urban flooding will } \\
\text { increase, as seepage into urban communities will vary } \\
\text { with increase in flow. }\end{array}$ & $\begin{array}{l}\text { Flooding occurs every } \\
\text { year, } \\
\text { every 2, } 5,7,10,15,20, \\
\text { and 50 years }\end{array}$ \\
$\begin{array}{l}\text { Urban Flood } \\
\text { Risk }\end{array}$ & $\begin{array}{l}\text { The payment represents fees that will be paid annually } \\
\text { for the next 10 years. }\end{array}$ & $\$ 0, \$ 25, \$ 35, \$ 50, \$ 70$ \\
\hline $\begin{array}{l}\text { Annual } \\
\text { Payment }\end{array}$ &
\end{tabular}

\subsubsection{Levels within Choice Cards/ SAS Process}

The levels in the choice cards were designed in light of both scientifically plausible scenarios with respect to varying degrees of restoration and also mutually exclusive restoration scenarios. Both the hydrological model and species model choice cards adapted from Milon et al. (1999) generated 29,403 possible combinations of levels within the choice cards. These combinations were developed through the SAS Data step with array methods and Procedure Transpose, as well as the SAS Macro facility in order to create each choice card. From the 58,806 possible combinations $(29,403$ possible combinations in each set) within both choice card sets, we implemented the fractional factorial design though which 40 choice cards were chosen for this study with 20 cards from each set To select these 40 cards from the considerable choice pool, we eliminated cards that contained restoration plans in which one plan dominated the other as a clear choice. We essentially looked for selections that would pose more of an ambiguous choice while modeling these plans after realistic restoration scenarios.

As for the choice card with the additional attributes, 9 attributes and the price attribute would have produced too large of a choice card matrix for respondents to focus on and make a clear decision. In the interest of shortening the individual choice card matrix, we paired two ecological attributes and two social attributes along with the price attribute in order to produce a 5x3 matrix. After imposing a few intuitive rules on 
possible attribute pairings, 20 different combinations of attributes within the choice cards were generated. We employed the SAS procedure described above on each of these 20 combinations resulting in various total combinations for each of the choice cards.

Depending on the attribute pairing, these possible combinations ranged from as low as 256 combinations to as high as 2,048 combinations. However, we selected only 20 choice cards for use in this study, despite the wide range of combinations. Figure 3.1 displays a hydrological model choice card combination used in this study, while Figure 3.2 displays a species model choice card and Figure 3.3 features a choice card containing additional attributes. 
Figure 3.1: Hydrological Model Choice Card Example Adapted from Milon et al. (1999)

\begin{tabular}{|c|c|c|}
\hline $\begin{array}{l}\text { Restoration } \\
\text { Attributes }\end{array}$ & $\begin{array}{c}\text { Restoration } \\
\text { Plan A }\end{array}$ & $\begin{array}{c}\text { Restoration } \\
\text { Plan B }\end{array}$ \\
\hline Lake Okeechobee & $\begin{array}{c}75 \% \\
\text { of the time, lake levels are } \\
\text { similar to historic, pre- } \\
\text { drainage conditions }\end{array}$ & $\begin{array}{c}75 \% \\
\text { of the time, lake levels are } \\
\text { similar to historic, pre- } \\
\text { drainage conditions }\end{array}$ \\
\hline Water Conservation Area & $\begin{array}{l}\mathbf{5 0} \% \\
\text { of the time, water levels are } \\
\text { similar to historic, pre- } \\
\text { drainage conditions }\end{array}$ & $\begin{array}{c}90 \% \\
\text { of the time, water levels are } \\
\text { similar to historic, pre- } \\
\text { drainage conditions }\end{array}$ \\
\hline Everglades National Park & $\begin{array}{l}5 \mathbf{5 0} \% \\
\text { of the time, water levels are } \\
\text { similar to historic, pre- } \\
\text { drainage conditions }\end{array}$ & $\begin{array}{c}75 \% \\
\text { of the time, water levels are } \\
\text { similar to historic, pre- } \\
\text { drainage conditions }\end{array}$ \\
\hline Farmland Acreage & $\begin{array}{l}\text { No change } \\
\text { in farmland acreage }\end{array}$ & $\begin{array}{l}100,000 \\
\text { farmland acre reduction }\end{array}$ \\
\hline Restrictions on Water Use & $\begin{array}{c}1 \text { days per week outdoor } \\
\text { use and } \\
\begin{array}{c}40 \% \text { reduction in } \\
\text { indoor use }\end{array}\end{array}$ & $\begin{array}{l}2 \text { day per week outdoor } \\
\text { use and } \\
\mathbf{2 5} \% \text { reduction in indoor } \\
\text { use }\end{array}$ \\
\hline Annual cost per Household & $\begin{array}{l}\$ 0 \text { increase per year in } \\
\text { water utility bill }\end{array}$ & $\begin{array}{l}\$ 70 \text { increase per year in } \\
\text { water utility bill }\end{array}$ \\
\hline
\end{tabular}


Figure 3.2: Species Model Choice Card Example Adapted from Milon et al. (1999)

\begin{tabular}{|c|c|c|}
\hline $\begin{array}{c}\text { Restoration } \\
\text { Attributes }\end{array}$ & $\begin{array}{c}\text { Restoration } \\
\text { Plan A }\end{array}$ & $\begin{array}{c}\text { Restoration } \\
\text { Plan B }\end{array}$ \\
\hline & $\begin{array}{c}\text { Species population at } \\
\mathbf{2 0} \% \\
\text { of historic, pre-drainage } \\
\text { conditions }\end{array}$ & $\begin{array}{c}\text { Species population at } \\
\mathbf{5 0 \%} \\
\text { of historic pre-drainage } \\
\text { conditions }\end{array}$ \\
\hline & $\begin{array}{c}\text { Species population at } \\
75 \% \\
\begin{array}{c}75 \% \\
\text { of historic, pre-drainage } \\
\text { population levels }\end{array}\end{array}$ & $\begin{array}{c}\text { Species population at } \\
\mathbf{5 0} \% \\
\text { of historic, pre-drainage } \\
\text { population levels }\end{array}$ \\
\hline & $\begin{array}{c}\text { Species population at } \\
75 \% \\
\text { of historic, pre-drainage } \\
\text { population levels }\end{array}$ & $\begin{array}{c}\text { Species population at } \\
60 \% \\
\text { of historic, pre-drainage } \\
\text { population levels }\end{array}$ \\
\hline & $\begin{array}{c}\mathbf{1 0 0 , 0 0 0} \\
\text { farmland acre } \\
\text { reduction }\end{array}$ & $\begin{array}{c}\mathbf{2 0 0}, 000 \\
\text { farmland acre } \\
\text { reduction }\end{array}$ \\
\hline Restrictions on Water Use & $\begin{array}{c}2 \text { days per week outdoor } \\
\text { use and } \\
\mathbf{2 5 \%} \text { reduction in } \\
\text { indoor use }\end{array}$ & $\begin{array}{c}3 \text { day per week outdoor } \\
\text { use and } \\
10 \% \text { reduction in } \\
\text { indoor use }\end{array}$ \\
\hline $\begin{array}{l}\text { Annual Cost per } \\
\text { Household }\end{array}$ & $\begin{array}{l}\$ 35 \text { increase per year } \\
\text { in water utility bill }\end{array}$ & $\begin{array}{l}\$ 70 \text { increase per year } \\
\text { in water utility bill }\end{array}$ \\
\hline
\end{tabular}


Figure 3.3: Choice Card with Additional Attributes Example

\begin{tabular}{|c|c|c|c|}
\hline $\begin{array}{c}\text { Management } \\
\text { Attributes }\end{array}$ & $\begin{array}{l}\text { Take No } \\
\text { Action }\end{array}$ & $\begin{array}{c}\text { Management } \\
\text { Plan A }\end{array}$ & $\begin{array}{c}\text { Management } \\
\text { Plan B }\end{array}$ \\
\hline $\begin{array}{l}\text { Recreational } \\
\text { Activities in } \\
\text { Everglades National } \\
\text { Park (ENP) }\end{array}$ & $\begin{array}{c}10 \% \\
\text { decrease } \\
\text { in access to } \\
\text { recreational } \\
\text { activities in } \\
\text { ENP }\end{array}$ & $\begin{array}{c}10 \% \\
\text { increase } \\
\text { in access to } \\
\text { recreational } \\
\text { activities in ENP }\end{array}$ & $\begin{array}{c}40 \% \\
\text { increase } \\
\text { in access to } \\
\text { recreational } \\
\text { activities in ENP }\end{array}$ \\
\hline $\begin{array}{r}\text { Inland } M \\
\text { Hab }\end{array}$ & $\begin{array}{c}\mathbf{3 0 \%} \\
\text { increase } \\
\text { in inland } \\
\text { mangrove } \\
\text { habitat }\end{array}$ & $\begin{array}{c}10 \% \\
\text { increase } \\
\text { in inland } \\
\text { mangrove } \\
\text { habitat }\end{array}$ & $\begin{array}{c}10 \% \\
\text { decrease } \\
\text { in inland } \\
\text { mangrove } \\
\text { habitat }\end{array}$ \\
\hline $\begin{array}{c}\text { Municipal Water } \\
\text { Supplies }\end{array}$ & $\begin{array}{c}15 \% \\
\text { decrease } \\
\text { in High } \\
\text { Quality water } \\
\text { supplies }\end{array}$ & $\begin{array}{l}10 \% \\
\text { increase } \\
\text { in High Quality } \\
\text { water supplies }\end{array}$ & $\begin{array}{l}\text { No unmet } \\
\text { demands for } \\
\text { High Quality } \\
\text { water in the } \\
\text { future }\end{array}$ \\
\hline Urban $F$ & $\begin{array}{c}\text { Flooding } \\
\text { occurs } 1 \text { out } \\
\text { of every } 20 \\
\text { years }\end{array}$ & $\begin{array}{c}\text { Flooding occurs } \\
1 \text { out of every } \\
10 \text { years }\end{array}$ & $\begin{array}{c}\text { Flooding occurs } \\
1 \text { out of every } \\
5 \text { years }\end{array}$ \\
\hline $\begin{array}{l}\text { Cost to your } \\
\text { household per }\end{array}$ & $\begin{array}{c}\$ 0 \text { in Annual } \\
\text { Fees }\end{array}$ & $\begin{array}{c}\$ 35 \text { in Annual } \\
\text { Fees }\end{array}$ & $\begin{array}{c}\$ 70 \text { in Annual } \\
\text { Fees }\end{array}$ \\
\hline
\end{tabular}

\subsubsection{Description of Informational Videos}

An integral component in the creation of the survey instrument included

developing informational videos for respondent viewing prior to answering survey questions. As noted earlier, the Greater Everglades system is both extensive and dynamic in nature, and encompasses many societal and economic aspects of South Floridian life. 
As such, most people within the general public are not cognizant of the scientific underpinnings within this system and its inherent value. As previously mentioned in Chapter 2, Johnston et al. (2012) affirms this overall particular respondent disadvantage within discrete choice experiments, and suggests the development of scientifically relevant indicators to mitigate this complication. These "scientifically relevant indicators" refer to the attributes within the choice cards. Without an understanding of the scientific foundation of the Everglades, the general public will not be able to make an informed decision about how much they would be willing to pay for environmental goods and services provided by the Everglades, thereby distorting WTP estimates. As a result, we developed two informational videos and placed them before the two different sets of choice cards within the survey. The videos contained basic information vital to understanding the choice cards. The video shown before the Milon et al. (1999) adapted choice cards showcased a truncated version of the video used in the original Milon et al. (1999). We created the abridged version from the original informational script and their respective slide description. The video developed for the additional attributes revolved around those chosen attributes. See Appendix A and Appendix B for the complete video scripts for the truncated Milon et al. (1999) video and the video developed for this survey, respectively

In addition to the two informational videos, we also produced two explanatory videos, which aid in contextualizing the choice card for respondents. Both videos are less than 2 minutes in length and were developed in response to a concern that arose during the pilot survey. Many participants in the pilot study expressed a concern that despite the 
informational videos, they remained unsure of how to apply the information from the videos to the choice experiment. Therefore, we developed two videos placed after the informational video and in between the choice experiment, which gave further instruction on how to approach the choice cards and how the attributes related to one another. Please see Appendix C and Appendix D for the explanatory video created for the Milon et al. (1999) adapted choice cards and the video created for the choice cards with additional attributes, respectively.

\subsection{Survey Methods}

\subsubsection{Methodology}

The methodology featured in the current study centers around a discrete choice experiment, in which respondents indicate their preferred choice of restoration or management plan options and how much they would be willing to pay for a plan with a distinct, associated cost. The options for management and restoration plans are consolidated into a choice card. Throughout the survey, respondents saw four different choice cards, 2 of the Milon et al. (1999) adapted cards (one hydrological restoration card and one species restoration card) and 2 of the choice cards containing new attributes previously unconsidered in the Milon et al. (1999) study. The ecological and social attributes (see Table 3.1 and Table 3.2) represented the restoration of the selected environmental goods and services contained within the choice cards.

In preparation for the willingness to pay decision evoked from the choice cards, respondents watched a total of 4 videos designed solely for the purpose of use in this survey. Two of the videos were approximately 5 minutes and 30 seconds each and 
contained general information about the ecosystem services their social dynamics

pertinent to the choice cards. The informational videos were not placed within the survey to influence the outcome of the decision in either direction. The videos simply provided a general understanding of the current state of the Everglades, in recognition of potential limited understanding of this ecosystem within the general public of South Florida. The other two videos served the purpose of contextualizing the choice cards for the respondent in the event that after watching the informational videos, respondents were still unsure of how to approach the choice card.

\subsubsection{Hypotheses}

Following the previous Milon et al. (1999) study and a general understanding of priorities from South Florida, I developed two hypotheses for this study. The hypotheses for the present study are as follows:

$\mathrm{H}_{0}: m$ WTPWetlandSpecies $=m$ WTPFloridaBaySpecies $=m$ WTPDrylandSpecies $\mathrm{H}_{1}:$ mWTPWetlandSpecies $\neq m$ WTPFloridaBaySpecies $\neq m$ WTPDrylandSpecies

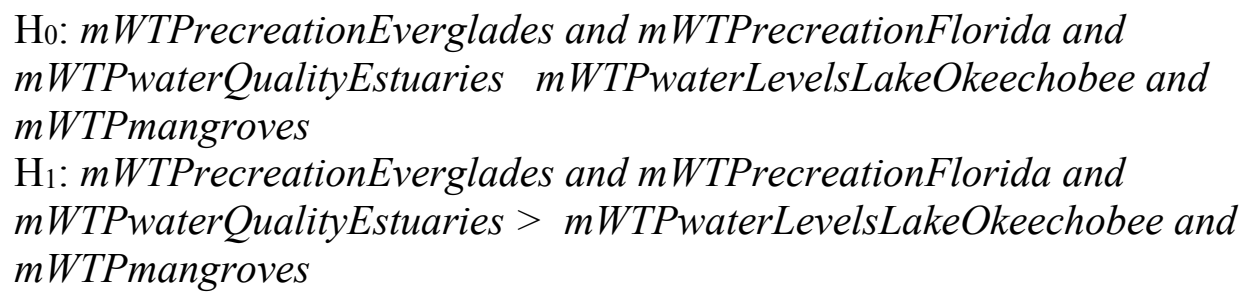

. Hypotheses (1) and (2) essentially set up the conditions for testing whether or not the marginal WTP for specific attributes are equal to one another, or not. I postulated hypothesis (1) on the basis of the results from the Milon et al. (1999) study, which indicated that both the "wetland" and "Florida Bay" species were preferred over the "dry 
land" species. Hypothesis (2) is predicated on the idea that marginal WTP for recreation in "Everglades National Park" and "Florida Bay" and for "water quality in the estuaries" will be higher than marginal willingness to pay for "water levels in Lake Okeechobee" and for "inland mangrove expansion."

\subsubsection{Measure}

I developed an approximately 120-question survey (including all variations of choice cards and sub-questions) in order to elicit respondents' preferences for Everglades Restoration and their WTP for the various ecological and social components of restoration (See Appendix E). Respondents received an e-mail with a link that led them to an online survey hosted on the Qualtrics survey platform. Through this web client, respondents were able to take the survey and watch all the necessary videos needed to complete the survey.

Figure 3.4: Screenshot of the survey hosted on the Qualtrics Platform

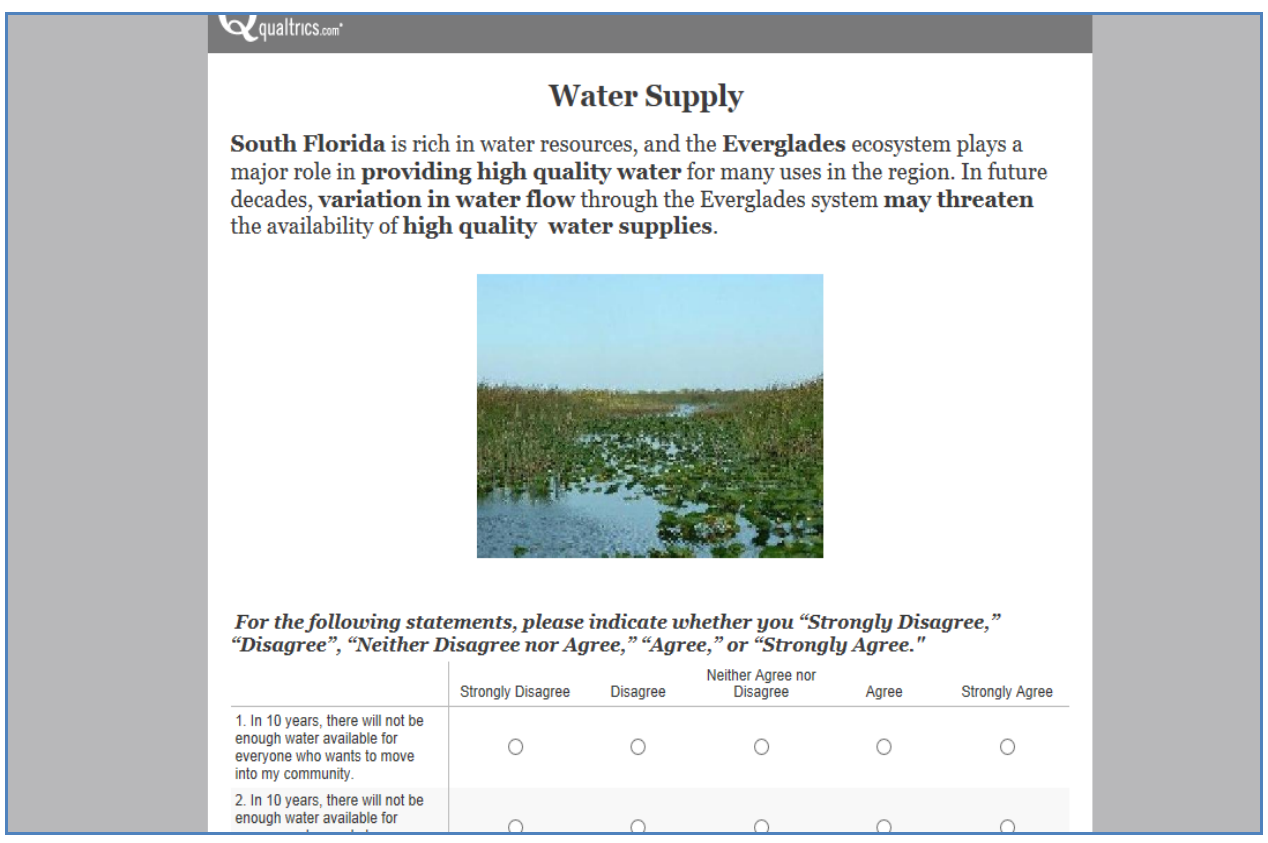


Figure 3.5: Screenshot of the embedded video within the survey on the Qualtrics Platform

\section{qualtrics.com"}

\section{Second Video}

Please watch the following video which will give you further instructions on how to answer the next questions in the survey.

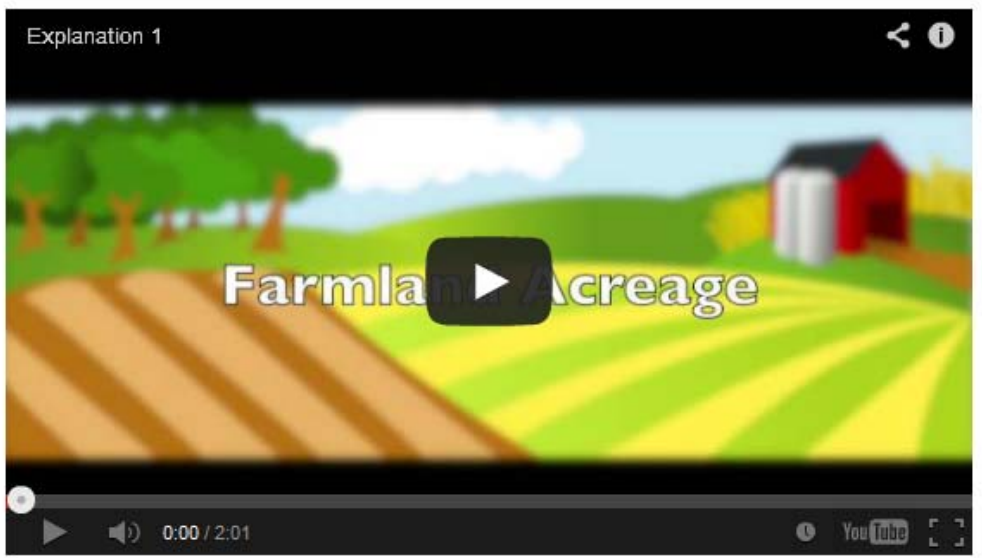

On a scale of 1-5, 1 being "Completely did not understand" and 5 being "Completely Understood," please indicate how well you understood the video.

\subsubsection{Sampling Methods}

Although there are many stakeholder groups across Florida, two stratified sample populations were selected for this study, which includes the general public of Florida and the saltwater anglers in Florida, that is, people who hold saltwater fishing licenses in Florida The general public living in South Florida and the rest of the state represent the largest stakeholder group, while the saltwater anglers stakeholder group presents a more targeted group with presumed higher interests in restoration. In order to reach a statistically representative population, we employed sampling methods that would read a broader population. As a result, we used online surveying through the Qualtrics survey 
software in order to efficiently reach a large number of Florida residents. The contact information for potential participants for the general public was purchased from a licensed vendor. The vendor provided contact information from Florida residents who applied to certain Florida state agency programs. The list composed the potential respondents list for the general public sample population. In order to reach saltwater anglers, we procured a public list containing the e-mail addresses of saltwater fishing license holders and used that for the basis of obtaining a saltwater angler sample population.

\subsubsection{Survey Dissemination and Responses}

Approximately 200,000 e-mails were sent to Florida residents within both targeted stakeholder groups, through an organized listserv. From the survey distribution, we have collected data from 1,843 respondents taken from two samples $(n=970$ within the general public and $n=873$ amongst licensed saltwater anglers in Florida). The response rate totaled around $1 \%$ in both populations. The survey yielded many incomplete surveys, which were excluded in the final count of 1,843 responses.

\subsubsection{Respondent Demographics}

Table 3.4 Respondents Demographics within the General Public and Saltwater Anglers Sample Population as Compared to Florida Census Demographics

\begin{tabular}{|c|c|c|c|c|c|}
\hline $\begin{array}{c}\text { Socio- } \\
\text { economic } \\
\text { Characteristi } \\
\text { c }\end{array}$ & & $\begin{array}{l}\text { General } \\
\text { Public } \\
\text { Sample }\end{array}$ & $\begin{array}{c}\text { Saltwater } \\
\text { Anglers } \\
\text { Sample (\%) }\end{array}$ & $\begin{array}{c}\text { Florida Census* } \\
\text { Characteristics }\end{array}$ & $\begin{array}{c}\text { Florida } \\
\text { Populatio } \\
\text { n (\%) }\end{array}$ \\
\hline $\begin{array}{l}\text { Mean Age } \\
\text { (years) }\end{array}$ & & 57.9 & 51.3 & Median Age (years) & 40.7 \\
\hline Gender $(\%)$ & Male & 64.74 & 81.9 & Male & 48.8 \\
\hline & Female & 35.26 & 18.1 & Female & 51.2 \\
\hline
\end{tabular}




\begin{tabular}{|c|c|c|c|c|c|}
\hline \multirow[t]{8}{*}{ Race (\%) } & $\begin{array}{l}\text { White/Cau } \\
\text { casian } \\
\text { African }\end{array}$ & 79.3 & 84.6 & White/Caucasian & 65.7 \\
\hline & $\begin{array}{l}\text { African } \\
\text { American }\end{array}$ & 2.2 & 0.5 & African American & 14.6 \\
\hline & Hispanic & 9.1 & 6.1 & Hispanic & 16.8 \\
\hline & $\begin{array}{l}\text { Asian } \\
\text { Native }\end{array}$ & 0.7 & 0.2 & Asian & 1.7 \\
\hline & $\begin{array}{l}\text { American } \\
\text { Pacific }\end{array}$ & 0.1 & 1.2 & Native American & 0.3 \\
\hline & Islander & 0.1 & 0 & Pacific Islander & 0.1 \\
\hline & Other & 1.4 & 1 & & \\
\hline & $\begin{array}{l}\text { Choose not } \\
\text { to indicate }\end{array}$ & 7.1 & 6.4 & & \\
\hline Educational & Less than & & & & \\
\hline \multirow[t]{7}{*}{ Attainment } & $\begin{array}{l}\mathrm{HS} \\
\mathrm{HS}\end{array}$ & 0.2 & 0.2 & Less than 9th Grade & 6 \\
\hline & $\begin{array}{l}\text { Diploma/G } \\
\text { ED } \\
2 \mathrm{yr}\end{array}$ & 11.7 & 13.9 & $\begin{array}{l}\text { 9th to } 12 \text { th grade, no } \\
\text { diploma }\end{array}$ & 8.2 \\
\hline & $\begin{array}{l}\text { College } \\
4 \mathrm{yr}\end{array}$ & 17.1 & 17.3 & $\begin{array}{l}\text { High school graduate } \\
\text { Some college, no }\end{array}$ & 28.2 \\
\hline & $\begin{array}{l}\text { College } \\
\text { Master's }\end{array}$ & 33.0 & 33.6 & degree & 21.3 \\
\hline & $\begin{array}{l}\text { Degree } \\
\text { Profession }\end{array}$ & 25.1 & 20.5 & Associate's Degree & 7.7 \\
\hline & $\begin{array}{l}\text { al Degree } \\
\text { Doctoral }\end{array}$ & 6.0 & 6.5 & $\begin{array}{l}\text { Bachelor's Degree } \\
\text { Graduate or }\end{array}$ & 17.9 \\
\hline & $\begin{array}{l}\text { Degree } \\
\text { Less than }\end{array}$ & 7.0 & 8 & Professional Degree & 10.6 \\
\hline \multirow[t]{11}{*}{ Income $(\%)$} & $\begin{array}{l}\$ 20,000 \\
\$ 20,000-\end{array}$ & $4.57 \%$ & $2.2 \%$ & Less than $\$ 10,000^{* *}$ & 7.2 \\
\hline & $\begin{array}{l}\$ 39,999 \\
\$ 40,000-\end{array}$ & $7.66 \%$ & $4.5 \%$ & $\$ 10,000-\$ 14,999$ & 5.4 \\
\hline & $\begin{array}{l}\$ 59,999 \\
\$ 60,000-\end{array}$ & $15.00 \%$ & $12.3 \%$ & $\$ 15,000-\$ 24,999$ & 10.7 \\
\hline & $\begin{array}{l}\$ 79,999 \\
\$ 80,000-\end{array}$ & $18.62 \%$ & $15.2 \%$ & $\$ 25,000-\$ 34,999$ & 10.4 \\
\hline & $\begin{array}{l}\$ 99,999 \\
\$ 100,000-\end{array}$ & $12.77 \%$ & $11.9 \%$ & $\$ 35,000-\$ 49,999$ & 13.7 \\
\hline & $\begin{array}{l}\$ 119,999 \\
\$ 120,000-\end{array}$ & $17.98 \%$ & $15.7 \%$ & $\$ 50,000-\$ 74,999$ & 18.2 \\
\hline & $\begin{array}{l}\$ 139,999 \\
\$ 140,000-\end{array}$ & $5.85 \%$ & $8.1 \%$ & $\$ 75,000-\$ 99,999$ & 12.2 \\
\hline & $\begin{array}{l}\$ 159,999 \\
\$ 160,000-\end{array}$ & $6.81 \%$ & $7.3 \%$ & $\$ 100,000-\$ 149,999$ & 12.8 \\
\hline & $\begin{array}{l}\$ 179,999 \\
\$ 180,000-\end{array}$ & $2.13 \%$ & $3.1 \%$ & $\$ 150,000-\$ 199,999$ & 4.8 \\
\hline & $\$ 199,999$ & $2.23 \%$ & $3.9 \%$ & & \\
\hline & More than & $6.38 \%$ & $15.8 \%$ & More than $\$ 200,000$ & 4.6 \\
\hline
\end{tabular}




\begin{tabular}{|c|c|c|c|c|c|}
\hline & $\begin{array}{l}\$ 200,000 \\
\text { Mean } \\
\text { Household } \\
\text { Income }\end{array}$ & $\$ 85,000$ & $\$ 105,000$ & & $\$ 66,599$ \\
\hline \multicolumn{6}{|l|}{ Degree in Env } \\
\hline \multirow[t]{2}{*}{ Sciences } & Yes & 14.2 & 22.8 & & \\
\hline & No & 85.8 & 77.2 & & \\
\hline \multirow{7}{*}{$\begin{array}{l}\text { Political Self } \\
\text { Identification }\end{array}$} & & & & $\begin{array}{l}* * \text { reflects household } \\
\text { data in } \mathrm{F} 1 \mathrm{n}=\end{array}$ & \\
\hline & Democrat & 32.89 & 22.8 & $115,226,802$ & \\
\hline & $\begin{array}{l}\text { Republican } \\
\text { Independe }\end{array}$ & 26.29 & 34.5 & & \\
\hline & $\mathrm{nt}$ & 28.76 & 28.1 & & \\
\hline & Other & 3.4 & 3.9 & & \\
\hline & Not & & & & \\
\hline & Interested & 8.66 & 10.8 & & \\
\hline
\end{tabular}

* Source: (U.S. Department of Commerce, 2012)

Table 3.4 displays the demographic results from both the respondents in the general public and saltwater anglers sample populations in comparison to recent Florida state census data. Within the general public sample population, the average age for respondents was 57.9 years, with a majority of male respondents (67.74\%). $33 \%$ of respondents indicated they obtained a four- year college degree, though only $14.2 \%$ indicated they had a degree in the environmental sciences. The mean household income was estimated at $\$ 85,000$ and most respondents (32.89\%) identified as Democrats. Since the income data were segmented into categorical data, I obtained the mean income by calculating the mean amongst the categories and establishing the midpoint within that category's range, or $\$ 85,000$. As evidenced within the table, the survey methods led to the oversampling of Caucasians within the general public by approximately 14 percentage points, while Hispanics and African Americans were under sampled by 7.7 and 12.4 percentage points, respectively, which represents an biased sample. In fact, 
much of the demographics obtained for the general public sample population represents a higher than average statistic when compared Florida Census data (U.S. Department of Commerce, 2012).

The over - and under- sampling within the sample population was likely the result of to endogenous stratification (Loomis, 2003), in which people who have an active and avid interest in the survey chose to respond more frequently than people who did not have an interest. Normally, endogenous stratification s is more commonly seen through on-site sampling, in which people who participate more frequently in certain activities have a greater chance of being sampled (Gonzalez, Loomis, \& Gonzalez-Caban, 2008; Martinez-Espineira et al., 2008). This principle can be applied to this sample population, since over 100,000 e-mails were sent to Florida residents in order to elicit a high sample size. However, since the online distribution was not targeted, we hoped that we would achieve a random sample. We did not achieve this outcome, since people who had a vested interest in answering the survey mostly responded to the survey. Instead, the average respondent in the general public sample represented a 58-year-old male with a four-year college degree from a household with a mean income of $\$ 85,000$. The average representation excludes the values and preferences of many minority groups.

Within the saltwater anglers sample population, the disparity between the census population and the sample population is larger than that of the general public sample population. $84.6 \%$ of respondents in the saltwater anglers population identified as Caucasian with most respondents leaning Republican at $34.5 \%$ with a mean income of $\$ 105,000$. Males $(81.9 \%)$ were overwhelmingly represented in this sample, with an average age of 51.3 years, slightly lower than in the general public. Again, $33.6 \%$ of 
respondents indicated that they obtained a 4 year degree, though only $22.8 \%$ held a degree in the environmental sciences.

\subsubsection{Survey Analysis}

In order to compute both the descriptive and inferential statistics, as well as the regression analysis included in this study, we used both Stata and SPSS software

\subsection{Methodology Challenges}

\subsubsection{Methodology Challenges}

The empirical research process requires a fastidious amount of attention to detail and oftentimes revision of the initial methodological approaches. As with many studies, the survey design within this study necessitated an iterative process. This essential component frames the entire study and is particularly difficult to hone in on when examining a subject matter as dynamic as environmental goods and services. The Everglades ecosystem is extensive and differs dramatically depending on local factors. As such, the Everglades provisions a significant amount of ecosystem services within South Florida, all of which could not be accommodated by the methodology in this study.

Within a choice card, only a certain amount of attributes can be included within the card matrix before a point of distraction and fatigue may emanate from the respondents. Placing too many attributes within the choice cards expands the choice card matrix, which may further complicate an already complex decision making process. In order to remove this possible complication, but also include the ecological and social attributes we selected for the study (See Table 3. 3) we decided to change the attributes 
and the combination of attributes within a $5 \times 3$ matrix (See Figure 3.3) In other words, the dimension of the $5 \times 3$ matrix remains stable as it always contains 4 attributes and the price attribute as well as 3 options for management plans. However, the combination of the ecological and social attributes changed in order to represent more tradeoffs scenarios and accommodate more attributes within the choice experiment. As a result, 20 different combinations of attributes were represented in 20 different choice cards. None of the choice cards contained the same patterns of attributes.

Consequently, unforeseen complications arose in the data analysis stage due to the implementation of this methodology. Within the primary analysis, no patterns of choice decisions could be inferred since the attributes did not remain stable within any of the choice cards, as they did in the Milon et al. (1999) adapted cards. Therefore, the primary analysis could not inform the regression analysis. Furthermore, the regression models were unable to run within either Stata or SPSS software as a result of many missing observations within the merged datasets. In addition to placing various combinations of attributes within the choice card matrices, in order to ensure that the respondents saw most of the attributes the choice cards were split into sets of 10 . Since only 4 ecological or social attributes could be combined within each choice card, respondents were presented with 2 different choice cards, so the respondents may encounter at maximum 8 of the 9 different attributes. When these separate observations were combined within the datasets to represent each individual respondent, this merge produced many missing observations. However, I considered this merge necessary in order to run regression models that represented the full set of attributes and its effect on the dependent variable. The myriad missing observations did not run in either SPSS or Stata as a full set, which 
was a critical setback in our efforts to generate WTP values for these environmental goods and services.

\subsubsection{Addressing Sampling Methodology}

As previously mentioned in Section 3.2.6, the representation of minority groups like Hispanics and African Americans were under sampled within the survey in the general public sample population, as a result of our sampling methodology which led to an endogenously stratified sample. In order to remedy this problem and increase the representation, we re-launched the survey again and used the Qualtrics survey panels in an effort to re-approach our sampling methods in order to target more minority groups and increase their representation within the general public sample population to reflect Florida census data. Table 3.6 reflects the re-adjusted figures from the new respondents within the general public sample population.

Table 3.5: Revised Figures for Respondent Demographics within the General Public and Saltwater Anglers Sample Population as Compared to Florida Census Demographics

\begin{tabular}{|c|c|c|c|c|c|}
\hline $\begin{array}{l}\text { Socioeconom } \\
\text { ic } \\
\text { Characteristi } \\
\text { c }\end{array}$ & & $\begin{array}{c}\text { General } \\
\text { Public } \\
\text { Sample }\end{array}$ & $\begin{array}{c}\text { Saltwater } \\
\text { Anglers } \\
\text { Sample (\%) }\end{array}$ & $\begin{array}{c}\text { Florida Census* } \\
\text { Characteristics }\end{array}$ & $\begin{array}{c}\text { Florida } \\
\text { Populatio } \\
\text { n (\%) }\end{array}$ \\
\hline $\begin{array}{l}\text { Mean Age } \\
\text { (years) }\end{array}$ & & 50.6 & 51.3 & Median Age (years) & 40.7 \\
\hline Gender (\%) & Male & 50.8 & 81.9 & Male & 48.8 \\
\hline & $\begin{array}{l}\text { Female } \\
\text { White/Cau }\end{array}$ & 49.2 & 18.1 & Female & 51.2 \\
\hline Race $(\%)$ & $\begin{array}{l}\text { casian } \\
\text { African }\end{array}$ & 64.0 & 84.6 & White/Caucasian & 65.7 \\
\hline & American & 15.8 & 0.5 & African American & 14.6 \\
\hline & Hispanic & 15.7 & 6.1 & Hispanic & 16.8 \\
\hline & Asian & .34 & 0.2 & Asian & 1.7 \\
\hline & Native & .05 & 1.2 & Native American & 0.3 \\
\hline
\end{tabular}




\begin{tabular}{|c|c|c|c|c|c|}
\hline & American & & & & \\
\hline & $\begin{array}{l}\text { Pacific } \\
\text { Islander }\end{array}$ & .05 & 0 & Pacific Islander & 0.1 \\
\hline & Other & .69 & 1 & & \\
\hline & $\begin{array}{l}\text { Choose not } \\
\text { to indicate }\end{array}$ & 3.4 & 6.4 & & \\
\hline Educational & Less than & & & & \\
\hline Attainment & HS & 1.4 & 0.2 & Less than 9th Grade & 6 \\
\hline & HS & & & & \\
\hline & Diploma/G & & & 9th to 12 th grade, no & \\
\hline & ED & 21.8 & 13.9 & diploma & 8.2 \\
\hline & $2 \mathrm{yr}$ & & & & \\
\hline & College & 21.4 & 17.3 & High school graduate & 28.2 \\
\hline & $4 \mathrm{yr}$ & & & Some college, no & \\
\hline & College & 30.1 & 33.6 & degree & 21.3 \\
\hline & Master's & & & & \\
\hline & Degree & 16.3 & 20.5 & Associate's Degree & 7.7 \\
\hline & Profession & & & & \\
\hline & al Degree & 4.2 & 6.5 & Bachelor's Degree & 17.9 \\
\hline & Doctoral & & & Graduate or & \\
\hline & Degree & 4.6 & 8 & Professional Degree & 10.6 \\
\hline & Less than & & & & \\
\hline Income $(\%)$ & $\$ 20,000$ & 10.7 & 2.2 & Less than $\$ 10,000^{* *}$ & 7.2 \\
\hline & $\$ 20,000-$ & & & & \\
\hline & $\$ 39,999$ & 19.0 & 4.5 & $\$ 10,000-\$ 14,999$ & 5.4 \\
\hline & $\$ 40,000-$ & & & & \\
\hline & $\$ 59,999$ & 17.2 & 12.3 & $\$ 15,000-\$ 24,999$ & 10.7 \\
\hline & $\$ 60,000-$ & & & & \\
\hline & $\$ 79,999$ & 17.7 & 15.2 & $\$ 25,000-\$ 34,999$ & 10.4 \\
\hline & $\$ 80,000-$ & & & & \\
\hline & $\$ 99,999$ & 10.6 & 11.9 & $\$ 35,000-\$ 49,999$ & 13.7 \\
\hline & $\$ 100,000-$ & & & & \\
\hline & $\$ 119,999$ & 10.8 & 15.7 & $\$ 50,000-\$ 74,999$ & 18.2 \\
\hline & $\$ 120,000-$ & & & & \\
\hline & $\$ 139,999$ & 3.8 & 8.1 & $\$ 75,000-\$ 99,999$ & 12.2 \\
\hline & $\$ 140,000-$ & & & & \\
\hline & $\$ 159,999$ & 4.2 & 7.3 & $\$ 100,000-\$ 149,999$ & 12.8 \\
\hline & $\$ 160,000-$ & & & & \\
\hline & $\$ 179,999$ & 1.3 & 3.1 & $\$ 150,000-\$ 199,999$ & 4.8 \\
\hline & $\$ 180,000-$ & & & & \\
\hline & $\$ 199,999$ & 1.2 & 3.9 & & \\
\hline & More than & & & & \\
\hline & $\$ 200,000$ & 3.4 & 15.8 & More than $\$ 200,000$ & 4.6 \\
\hline & Mean & & & & \\
\hline & Household & & & & \\
\hline & Income & $\$ 75,000$ & $\$ 105,000$ & & $\$ 66,599$ \\
\hline Degree in & & & & & \\
\hline Env Sciences & Yes & 10.8 & 22.8 & & \\
\hline & No & 89.2 & 77.2 & & \\
\hline
\end{tabular}


Political Self Identification Republican Independe nt

Other Not Interested
39.2

22.1 25.4

2.9

10.5
** reflects household data in $\mathrm{Fl} \mathrm{n}=$ $22.8 \quad 115,226,802$ 34.5

28.1

3.9

After the re-launch of the survey, the general public sample population increased from $n=$ 970 to $n=2,032$. The saltwater anglers sample remained the same, as this population was not re-targeted in the re-launch. Table 3.5 displays re-adjusted figures for racial groups. As a result of the additional observations, White/Caucasians composed $64 \%$ of the sample, which is only 1.5 percentage points under the Florida census representation of 65.7\%. As for African Americans and Hispanics, both of whom were under sampled in the first launch the survey, now represents $15.8 \%$ and $15.7 \%$ of the current sample, respectively. The gender gap also within the original sample data closed to an almost equal representation at $50.8 \%$ males and $49.2 \%$ females within the revised sample population. The mean age of the general public sample also decreased from 57.9 to 50.6 years, and the mean income decreases from $\$ 85,000$ to $\$ 75,000$. The revised mean income is still higher when compared to Florida mean household income, $\$ 66,599$. As for political self-identification, the new sample population figures contained a higher proportion of self-identifying Democrats at $39.2 \%$ than Republicans at $22.1 \%$. These revised figures widened the gap between the representations of these two groups when compared to the original sample data. 


\section{CHAPTER 4: RESULTS}

\subsection{Descriptive Results- Primary Analysis}

\subsubsection{Respondent Characteristics}

In order to gauge the level of interaction respondents may have with natural systems in Florida, respondents answered a series of question indicating how often they participated in a select number of recreational activities. The results for the general public and saltwater angler sample populations are displayed in Table 4.1 and 4.2, respectively.

Table 4.1: General Public Respondent Characteristics- Frequency of Recreational Activities (\%)

\section{Recreational Activities - Saltwater Anglers $(n=873)$}

\begin{tabular}{|c|c|c|c|c|c|c|c|}
\hline Activities & $\begin{array}{c}\text { More } \\
\text { than } \\
\text { once a } \\
\text { week }\end{array}$ & $\begin{array}{l}\text { More } \\
\text { than } \\
\text { once a } \\
\text { month }\end{array}$ & $\begin{array}{c}\text { More than } \\
\text { once every } \\
3 \text { months }\end{array}$ & $\begin{array}{l}\text { More than } \\
\text { once every } \\
6 \text { months }\end{array}$ & $\begin{array}{c}\text { More } \\
\text { than } \\
\text { once a } \\
\text { year }\end{array}$ & $\begin{array}{c}\text { More } \\
\text { than } \\
\text { once } \\
\text { every } \\
\text { five } \\
\text { years }\end{array}$ & Never \\
\hline $\begin{array}{l}\text { Visiting } \\
\text { the beach }\end{array}$ & 10.1 & 21.8 & 21.3 & 12.9 & 17.3 & 11.4 & 5.2 \\
\hline Fishing & 5 & 12.1 & 11.5 & 8.4 & 12.1 & 14.2 & 36.4 \\
\hline $\begin{array}{l}\text { Boating } \\
\text { Paddle }\end{array}$ & 4.3 & 11.3 & 11.1 & 9.1 & 15.2 & 16.9 & 32.2 \\
\hline boarding & 2.1 & 3 & 4.3 & 3.8 & 4.3 & 7.3 & 75.2 \\
\hline $\begin{array}{l}\text { Scuba } \\
\text { diving } \\
\text { Free } \\
\text { diving }\end{array}$ & 1.4 & 2.2 & 3.8 & 4.1 & 5.5 & 8.7 & $\begin{array}{r}73.9 \\
76.6\end{array}$ \\
\hline $\begin{array}{c}\text { Snorkelin } \\
\mathrm{g}\end{array}$ & 2.4 & 4 & 7.2 & 7.9 & 11.9 & 14.4 & 52.2 \\
\hline $\begin{array}{l}\text { Swimmin } \\
\mathrm{g} \text { in the } \\
\text { open } \\
\text { water }\end{array}$ & 5 & 12.4 & 15.1 & 12.8 & 13. & 11.2 & 30.6 \\
\hline Kayaking & 2.5 & 6.5 & 6.5 & 6.8 & 9.2 & 12.1 & 57.4 \\
\hline
\end{tabular}

Overwhelmingly, the selection "Never" was the most frequent choice in the general public sample for the following activities: fishing (36.4\%), boating (32.2\%), paddle 
boarding (75.2\%), scuba diving (73.9\%), free diving (76.6\%), snorkeling (52.2\%), swimming in the open water (30.6\%), and kayaking (57.4\%). This observation indicates a relative disassociation with the environment in terms of recreational activities. However, activities like "visiting the beach" and "swimming in the open water" had a more evenly distributed activity frequency, indicating that activities that do not require special equipment are more frequented. This observation remains true even though the "Never" option elicited the highest frequency, in the "swimming in the open water" option.

However, the results from the saltwater anglers sample showed less consistency when compared with the general public sample. Most respondents in this sample indicated they "visit the beach" (29.9\%), "fish" (41.4\%), go boating (40.9\%), and "swim in the open water" (22.7\%) more than once a month. Yet, large amounts of respondents also asserted they never "paddle board" (68.4\%), "scuba dive" (52.7\%), "free dive" (55.2\%), or "kayak" (26.6\%). However, the "kayaking" activity frequency seemed more evenly distributed than the other activities for which "Never" was the most chosen answer. "Snorkeling" also follows a somewhat even frequency distribution, with most respondents (19.5\%) indicating they snorkel more than once every 6 months.

Table 4.2: Saltwater Anglers Respondent CharacteristicsFrequency of Recreational Activities (\%)

Recreational Activities - Saltwater Anglers (n= 873)

Frequency (\%)

\begin{tabular}{|c|c|c|c|c|c|c|c|}
\hline Activities & $\begin{array}{c}\text { More } \\
\text { than once } \\
\text { a week }\end{array}$ & $\begin{array}{l}\text { More } \\
\text { than } \\
\text { once a } \\
\text { month }\end{array}$ & $\begin{array}{c}\text { More } \\
\text { than once } \\
\text { every } 3 \\
\text { months }\end{array}$ & $\begin{array}{c}\text { More than } \\
\text { once every } \\
6 \text { months }\end{array}$ & $\begin{array}{c}\text { More } \\
\text { than } \\
\text { once a } \\
\text { year }\end{array}$ & $\begin{array}{c}\text { More } \\
\text { than } \\
\text { once } \\
\text { every } \\
\text { five } \\
\text { years }\end{array}$ & Never \\
\hline $\begin{array}{l}\text { Visiting the } \\
\text { beach }\end{array}$ & 15.4 & 29.9 & 22.3 & 12.4 & 13.2 & 5.3 & 1.6 \\
\hline
\end{tabular}




\begin{tabular}{cccccccc} 
Fishing & 24.3 & $\mathbf{4 1 . 4}$ & 18.2 & 8 & 4.8 & 2.8 & 0.6 \\
Boating & 22.9 & $\mathbf{4 0 . 9}$ & 16 & 8.3 & 5.5 & 3.9 & 2.5 \\
Paddle boarding & 2.2 & 6.3 & 6 & 4.7 & 6.3 & 6.2 & $\mathbf{6 8 . 4}$ \\
Scuba diving & 1.4 & 5.6 & 9.5 & 7.8 & 8.8 & 14.2 & $\mathbf{5 2 . 7}$ \\
Free diving & 2.1 & 6.5 & 10 & 9.3 & 10.2 & 6.8 & $\mathbf{5 5 . 2}$ \\
Snorkeling & 3.6 & 11.6 & 17.4 & $\mathbf{1 9 . 5}$ & 18.9 & 14.2 & 14.9 \\
Swimming in & & & & & & & \\
the open water & 6.8 & $\mathbf{2 2 . 7}$ & 21.5 & 15.2 & 13.4 & 7 & 13.4 \\
Kayaking & 6.2 & 16 & 16.6 & 10.5 & 12.4 & 11.7 & $\mathbf{2 6 . 6}$ \\
\hline
\end{tabular}

With regards to climate change and its impacts on Florida, the overwhelming majorities of respondents from both sample populations accept the realities of climate change and support certain actions to enhance the resiliency of Florida's ecological systems and economy. Figure 4.1 and 4.2 display the results from the general public sample and the saltwater angler sample, respectively, when asked whether they agreed with certain climate change statements. In both figures, "Strongly Agree" elicited the highest responses for the $1^{\text {st }}$ statement, concerned with whether or not "we should further development in low lying coastal areas in Florida (46.4\%)." In the general public sample, most respondents agreed that "we need to be more aggressive about Everglades Restoration" (40.0\%), and "climate change and its impacts pose a substantial risk towards the ecosystem services provided by the Everglades" (38.5\%).

Likewise, in the saltwater anglers sample, most respondents strongly agreed with all of the statements, yet by smaller percentages. $48.8 \%$ of respondents strongly agreed with "restricting further development in low lying coastal areas in Florida," while 40.8\% of respondents strongly agreed with getting "aggressive about Everglades restoration," and only $35.5 \%$ of respondents strongly agreed with the statement "climate change and 
its impacts pose a substantial risk towards the ecosystem services provided by the Everglades."

In order to assess the respondents' priorities within environmental public policy, respondents were asked to indicate on a 7-point scale whether they prioritized protecting the environment or economic growth. Figure 6.3 displays the results of where respondents fall on this 7 point scale, with "protecting the environment" at the far left and "economic growth" at the far right. Respondents in both sample populations strongly favored "protecting the environment," with $61.2 \%$ of the general public and $74.8 \%$ of the saltwater anglers on the left-hand (points 1-3) side of the spectrum.

Figure 4.1: General Public Respondents - Climate Change Attitudes (\%)

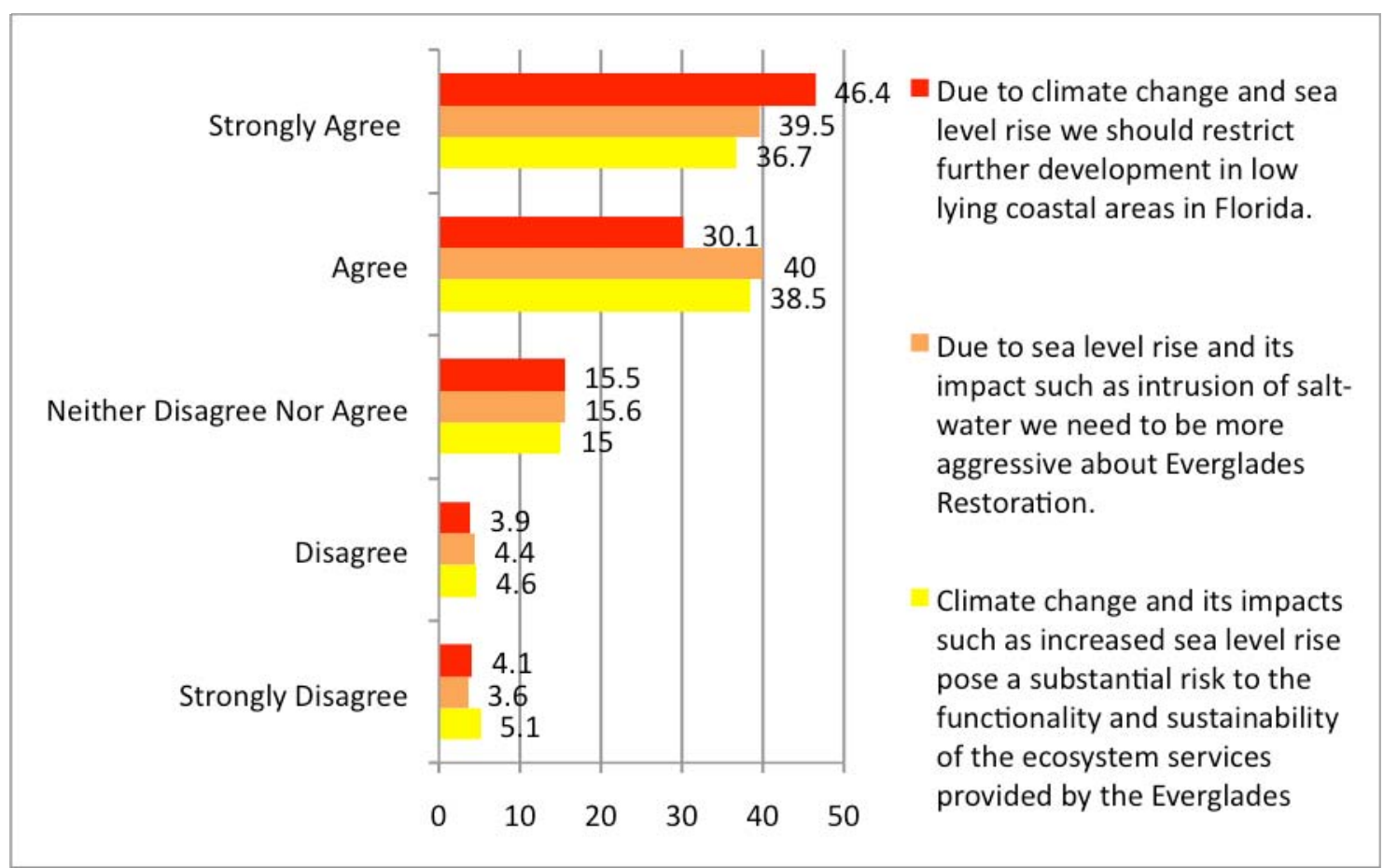


Figure 4.2: Saltwater Angler Respondents - Climate Change Attitudes (\%)

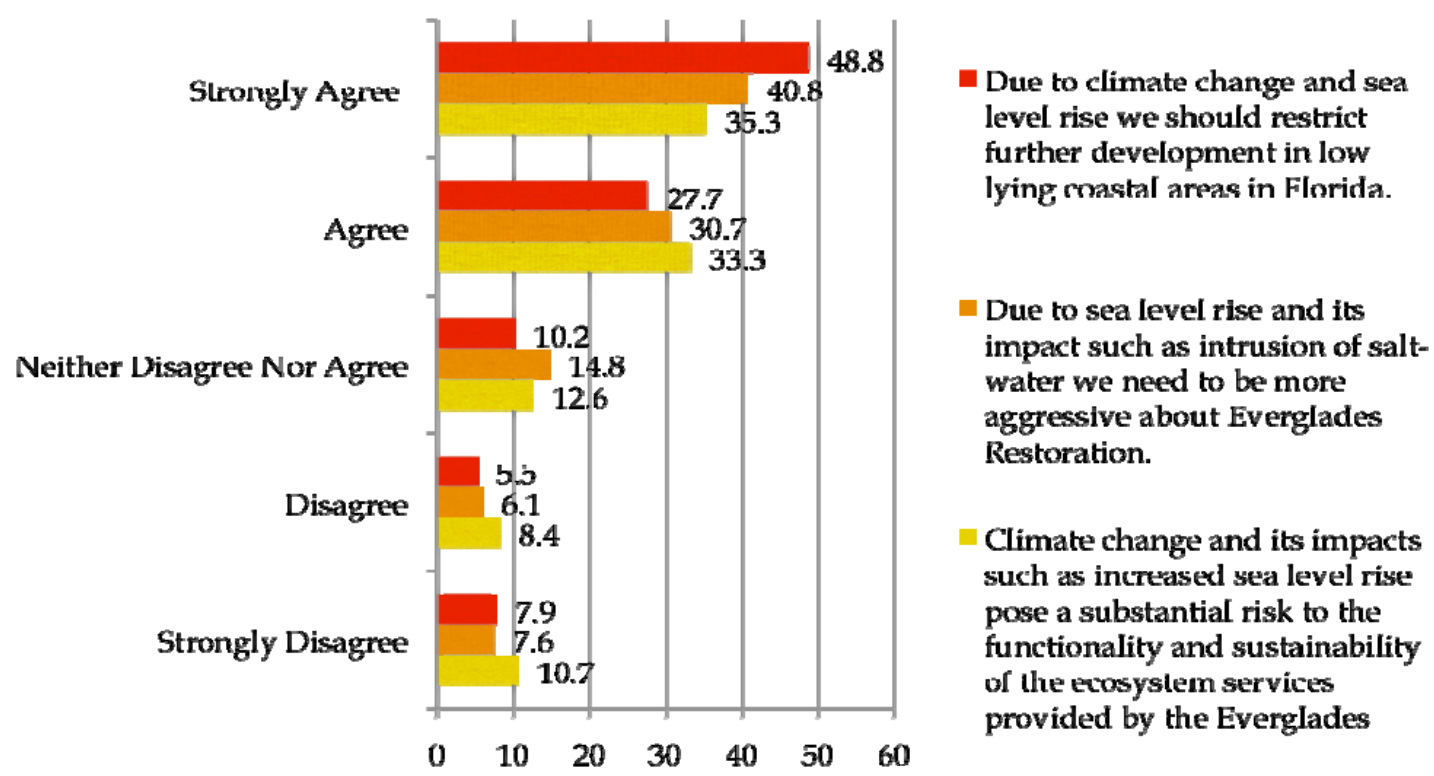

Figure 4.3: Priorities for Environmental Public Policy: Protecting the Environment vs. Economic Growth (\%) - General Public and Saltwater Angler Respondents

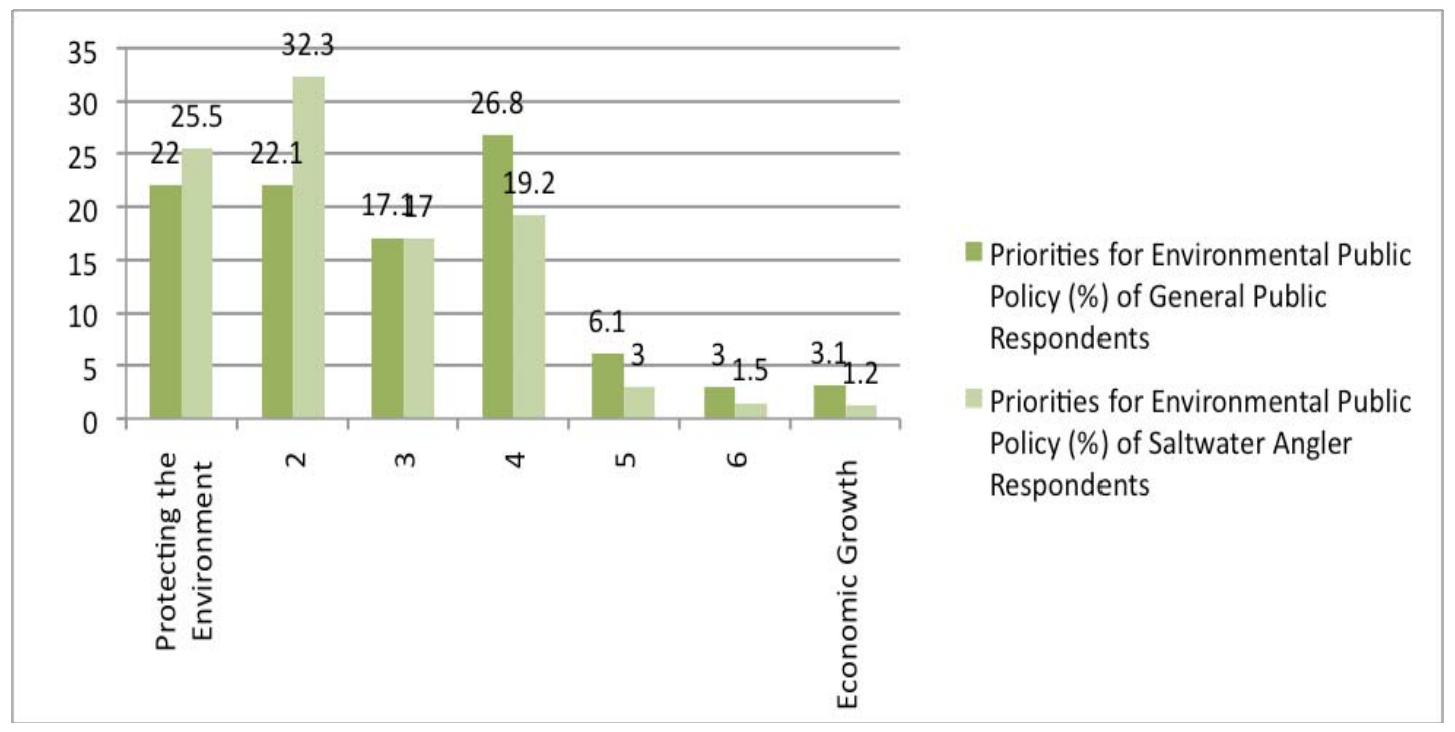


4.2 Restoration Plan Attribute Selection by Level- Choice cards adapted from Milon et al. (1999)

4.2.1. Hydrological Model Restoration Plan Attribute Selection by Level

Given the variation within the choice cards by attribute and levels, Table 4.3 and 4.4 summarize the distribution of respondent choice amongst attributes by level for both sample populations. Table 4.3 shows the frequency of choice selection for the hydrological model adaption from Milon et al. (1999) by attribute in both percentage and numerical value. The results from both samples seemed to display a consensus amongst the most favorable levels per attribute. Within both samples, respondents favored $\mathbf{7 5 \%}$ restoration of freshwater flow within Lake Okeechobee (General Public -39.8\%;

Saltwater Anglers- 39.1\%), 90\% of restoration within the Water Conservation Areas (General Public -36.5\%; Saltwater Anglers- 43.8\%), and 75\% of restoration within Everglades National Park (General Public -45.8\%; Saltwater Anglers- 48.1\%). Respondents were also willing to accept a reduction of $\mathbf{1 0 0 , 0 0 0}$ acres of farmland and

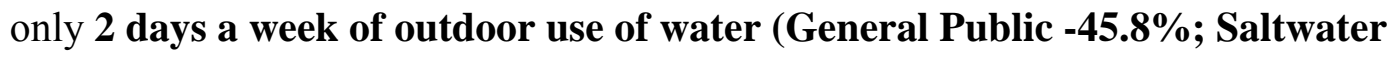

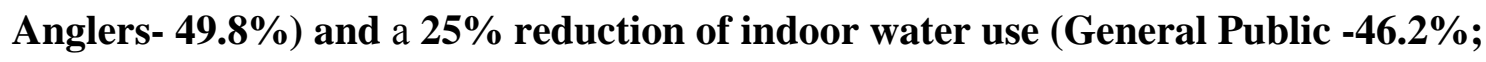
Saltwater Anglers- 47.7\%). As for willingness to pay for restoration plan, both sample populations were willing to pay the highest amount of $\mathbf{\$ 7 0}$ for the hydrological restoration of the Everglades, with the general public at $36.4 \%$ and the saltwater

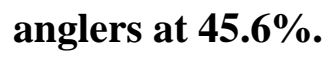


Table 4.3: Choice Selection Frequency for Hydrological Model- Milon et al. (1999)

\begin{tabular}{|c|c|c|c|c|c|}
\hline $\begin{array}{c}\text { Hydrological Model } \\
\text { Attributes }\end{array}$ & Levels & $\begin{array}{l}\text { General } \\
\text { Public }\end{array}$ & $\begin{array}{l}\text { General } \\
\text { Public (\%) }\end{array}$ & $\begin{array}{l}\text { Saltwater } \\
\text { Anglers }\end{array}$ & $\begin{array}{c}\text { Saltwater } \\
\text { Anglers( \%) }\end{array}$ \\
\hline \multirow[t]{3}{*}{ Lake Okeechobee } & 60 & 609 & 30.0 & 216 & 24.7 \\
\hline & 75 & 809 & 39.8 & 341 & 39.1 \\
\hline & 90 & 614 & 30.2 & 316 & 36.2 \\
\hline \multirow{4}{*}{$\begin{array}{l}\text { Water Conservation } \\
\text { Areas }\end{array}$} & & & & & \\
\hline & 50 & 685 & 33.7 & 224 & 25.7 \\
\hline & 75 & 606 & 29.8 & 267 & 30.6 \\
\hline & 90 & 741 & 36.5 & 382 & 43.8 \\
\hline \multirow[t]{3}{*}{$\begin{array}{l}\text { Everglades National } \\
\text { Park }\end{array}$} & 50 & 239 & 11.8 & 144 & 16.5 \\
\hline & 75 & 961 & 47.3 & 420 & 48.1 \\
\hline & 90 & 832 & 40.9 & 309 & 35.4 \\
\hline \multirow[t]{3}{*}{ Farmland Acreage } & 0 & 487 & 24 & 109 & 12.5 \\
\hline & 100,000 & 931 & 45.8 & 435 & 49.8 \\
\hline & 200,000 & 614 & 30.2 & 329 & 37.7 \\
\hline \multirow{5}{*}{$\begin{array}{l}\text { Restrictions on Water } \\
\text { Use }\end{array}$} & 1 day; & & & & \\
\hline & $\begin{array}{l}40 \% \\
2 \text { days; }\end{array}$ & 446 & 21.9 & 123 & 14.1 \\
\hline & $25 \%$ & 938 & 46.2 & 416 & 47.7 \\
\hline & 3 days; & & & & \\
\hline & $10 \%$ & 648 & 31.9 & 334 & 38.3 \\
\hline \multirow[t]{3}{*}{ Bid Values } & $\$ 0$ & 439 & 21.6 & 96 & 11 \\
\hline & $\$ 35$ & 853 & 42 & 379 & 43.4 \\
\hline & $\$ 70$ & 740 & 36.4 & 389 & 45.6 \\
\hline
\end{tabular}

4.2.2. Species Model Restoration Plan Attribute Selection by Level

However, the respondents within both sample groups were not unified in their preferences for restoration with regards to the species model attributes. The general public favored the restoration of wetland species population at $50 \%(45.4 \%$

favorability), while the same percentage of saltwater anglers favored $80 \%$ restoration of the wetland species population ( $43 \%$ favorability). As for the dry land species, both the general public (31.7\% favorability) and the saltwater anglers $\mathbf{( 3 8 . 8 \%}$ favorability) supported species restoration at $75 \%$. General public respondents supported restoration for Florida Bay species at $75 \%$ species population restoration 
with $36.1 \%$ favorability. However the saltwater anglers sample population favored restoration of the Florida Bay species at the highest level of $\mathbf{9 0 \%}$ at $\mathbf{4 0 . 6 \%}$ favorability. Both sample populations (General Public- 51.9\%; Saltwater Anglers$50.3 \%$ ) were willing to accept a $\mathbf{1 0 0 , 0 0 0}$-acre reduction in farmland. On the last two attributes, the general public and saltwater anglers favored different levels. The saltwater anglers were willing to pay $\mathbf{\$ 7 0}$ for species population restoration $(\mathbf{4 8 . 1 \% )}$ and therefore only accepted a smaller restriction of water use of $\mathbf{3}$ days a week of outdoor use and $10 \%$ reduction of indoor water usage (45\%). However, the general public was less willing to pay for species restoration with the majority at $\mathbf{4 7 . 9 \%}$ favoring the $\$ 35$ priced plan. As a result, the general public accepted more restrictions on their water usage at only 2 days a week of outdoor use and a $25 \%$ reduction indoor.

Table 4.4: Choice Selection Frequency for Species Model- Milon et al. (1999)

\begin{tabular}{|c|c|c|c|c|c|}
\hline $\begin{array}{l}\text { Species Model } \\
\text { Attributes }\end{array}$ & Levels & $\begin{array}{l}\text { General } \\
\text { Public }\end{array}$ & $\begin{array}{c}\text { General } \\
\text { Public (\%) }\end{array}$ & $\begin{array}{l}\text { Saltwater } \\
\text { Anglers }\end{array}$ & $\begin{array}{c}\text { Saltwater } \\
\text { Anglers( \%) }\end{array}$ \\
\hline \multirow[t]{3}{*}{ Wetland Species } & 20 & 475 & 23.4 & 128 & 14.7 \\
\hline & 50 & 923 & 45.4 & 370 & 42.4 \\
\hline & 80 & 634 & 31.2 & 375 & 43 \\
\hline \multirow[t]{3}{*}{ Dryland Species } & 50 & 821 & 40.4 & 288 & 33 \\
\hline & 65 & 567 & 27.9 & 246 & 28.2 \\
\hline & 75 & 644 & 31.7 & 339 & 38.8 \\
\hline \multirow{4}{*}{$\begin{array}{l}\text { Florida Bay } \\
\text { Species }\end{array}$} & & & & & \\
\hline & 60 & 603 & 29.7 & 186 & 21.3 \\
\hline & 75 & 733 & 36.1 & 333 & 38.1 \\
\hline & 90 & 696 & 34.2 & 354 & 40.6 \\
\hline \multirow[t]{3}{*}{ Farmland Acreage } & 0 & 308 & 15.2 & 59 & 6.8 \\
\hline & 100,000 & 1055 & 51.9 & 439 & 50.3 \\
\hline & 200,000 & 669 & 32.9 & 375 & 43 \\
\hline \multirow{5}{*}{$\begin{array}{l}\text { Restrictions on } \\
\text { Water Usage }\end{array}$} & 1 day; & & & & \\
\hline & $40 \%$ & 416 & 20.5 & 97 & 11.1 \\
\hline & $\begin{array}{c}2 \text { days; } \\
25 \%\end{array}$ & 941 & 46.3 & 383 & 43.9 \\
\hline & 3 days; & & & & \\
\hline & $10 \%$ & 675 & 33.2 & 393 & 45 \\
\hline Bid Value & $\$ 0$ & 346 & 17 & 72 & 8.3 \\
\hline
\end{tabular}




$\begin{array}{lllll}\mathbf{\$ 3 5} & \mathbf{9 7 3} & \mathbf{4 7 . 9} & 381 & 43.6 \\ \mathbf{\$ 7 0} & 713 & 35.1 & \mathbf{4 2 0} & \mathbf{4 8 . 1}\end{array}$

\subsection{Management Plan Attribute Selection by Level}

\subsubsection{Management Plan Attribute Selection by Level - General Public}

Table 4.5 displays the frequency of the level selection by attribute in the choice cards containing new attributes for the general public sample population. Although the data from these choice cards could not be used for regression analysis (thereby, WTP values cannot be generated), these management attributes can still be used to inform preferences for restoration and tradeoffs. $32.7 \%$ of respondents support only a $20 \%$ decrease in fish abundance with an increase in water levels in Lake Okeechobee. As for water supply, respondents favored a restoration plan that included no unmet water demands for agricultural water supply (46.8\%) and municipal water supply (51.4\%). Respondents' favorability for increased access to recreational activities in Everglades National Park and Florida Bay was less pronounced with $\mathbf{3 4 . 1 \%}$ favoring a $40 \%$ increase access and in the ENP and only $28 \%$ favoring a $30 \%$ increase in access in Florida Bay. As for mangrove habitat, respondents supported a $10 \%$ increase of inland mangrove expansion (30.6\%). With regards to restrictions on urban expansion, the majority of respondents (51.2\%) favored no further expansion. Also, respondents were willing to accept an urban flood risk occurrence of every 5 years $(27.3 \%)$ in order to accommodate higher levels of water quality in estuaries on both sides of the coast. Respondents overwhelmingly favored (43.7\% favorability) the highest level of water quality within the estuaries, or poor water quality occurs every 30 years. In line with the 
most favorable attributes, most respondents were willing to pay $\mathbf{\$ 7 0}(\mathbf{3 2 . 1 \% )}$ ) for these management plan components.

Table 4.5: Choice Selection Frequency for Management Plan Attributes- General Public

\begin{tabular}{|c|c|c|c|c|}
\hline Attribute Name & $\begin{array}{l}\text { Attribute } \\
\text { Frequency } \\
\text { Total }\end{array}$ & Attribute Levels & $\begin{array}{l}\text { Attribute } \\
\text { Level } \\
\text { Frequency }\end{array}$ & $\begin{array}{l}\text { Attribute Level } \\
\text { Frequency (\%) }\end{array}$ \\
\hline $\begin{array}{l}\text { Water Levels in } \\
\text { Lake Okeechobee }\end{array}$ & 483 & $\begin{array}{l}\text { No change in fish } \\
\text { abundance } \\
\mathbf{2 0 \%} \text { decrease in } \\
\text { fish abundance } \\
40 \% \text { decrease in } \\
\text { fish abundance } \\
60 \% \text { decrease in } \\
\text { fish abundance } \\
80 \% \text { decrease in } \\
\text { fish abundance }\end{array}$ & $\begin{array}{l}28 \\
158 \\
41 \\
147 \\
109\end{array}$ & $\begin{array}{c}5.8 \\
32.7 \\
8.5 \\
30.4 \\
22.6\end{array}$ \\
\hline $\begin{array}{l}\text { Agricultural Water } \\
\text { Demands }\end{array}$ & 785 & $\begin{array}{c}\text { No unmet } \\
\text { demands } \\
5 \% \text { demands not } \\
\text { met } \\
10 \% \text { demands } \\
\text { not met } \\
20 \% \text { demands not } \\
\text { met } \\
30 \% \text { demands not } \\
\text { met }\end{array}$ & $\begin{array}{c}367 \\
119 \\
249 \\
17 \\
33\end{array}$ & $\begin{array}{r}\mathbf{4 6 . 8} \\
15.2 \\
31.7 \\
2.2 \\
4.2\end{array}$ \\
\hline $\begin{array}{l}\text { Municipal Water } \\
\text { Supply }\end{array}$ & 1,155 & $\begin{array}{l}10 \% \text { decrease } \\
10 \% \text { increase } \\
\text { No unmet } \\
\text { demands } \\
15 \% \text { decrease } \\
5 \% \text { increase }\end{array}$ & $\begin{array}{c}52 \\
291 \\
\\
594 \\
35 \\
183\end{array}$ & \begin{tabular}{c|c|c}
4.5 & \\
25.2 & \\
& \\
51.4 & \\
3.03 & \\
15.8 & &
\end{tabular} \\
\hline $\begin{array}{l}\text { Recreation in } \\
\text { Everglades National } \\
\text { Park }\end{array}$ & 1,077 & $\begin{array}{l}20 \% \text { decrease in } \\
\text { access } \\
20 \% \text { increase in } \\
\text { access } \\
30 \% \text { increase in } \\
\text { access } \\
10 \% \text { increase in } \\
\text { access } \\
10 \% \text { decrease in } \\
\text { access } \\
\mathbf{4 0 \%} \text { increase in }\end{array}$ & $\begin{array}{c}26 \\
210 \\
179 \\
234 \\
61 \\
367\end{array}$ & $\begin{array}{r}2.4 \\
19.5 \\
16.6 \\
21.7 \\
5.7 \\
34.1 \\
\end{array}$ \\
\hline
\end{tabular}




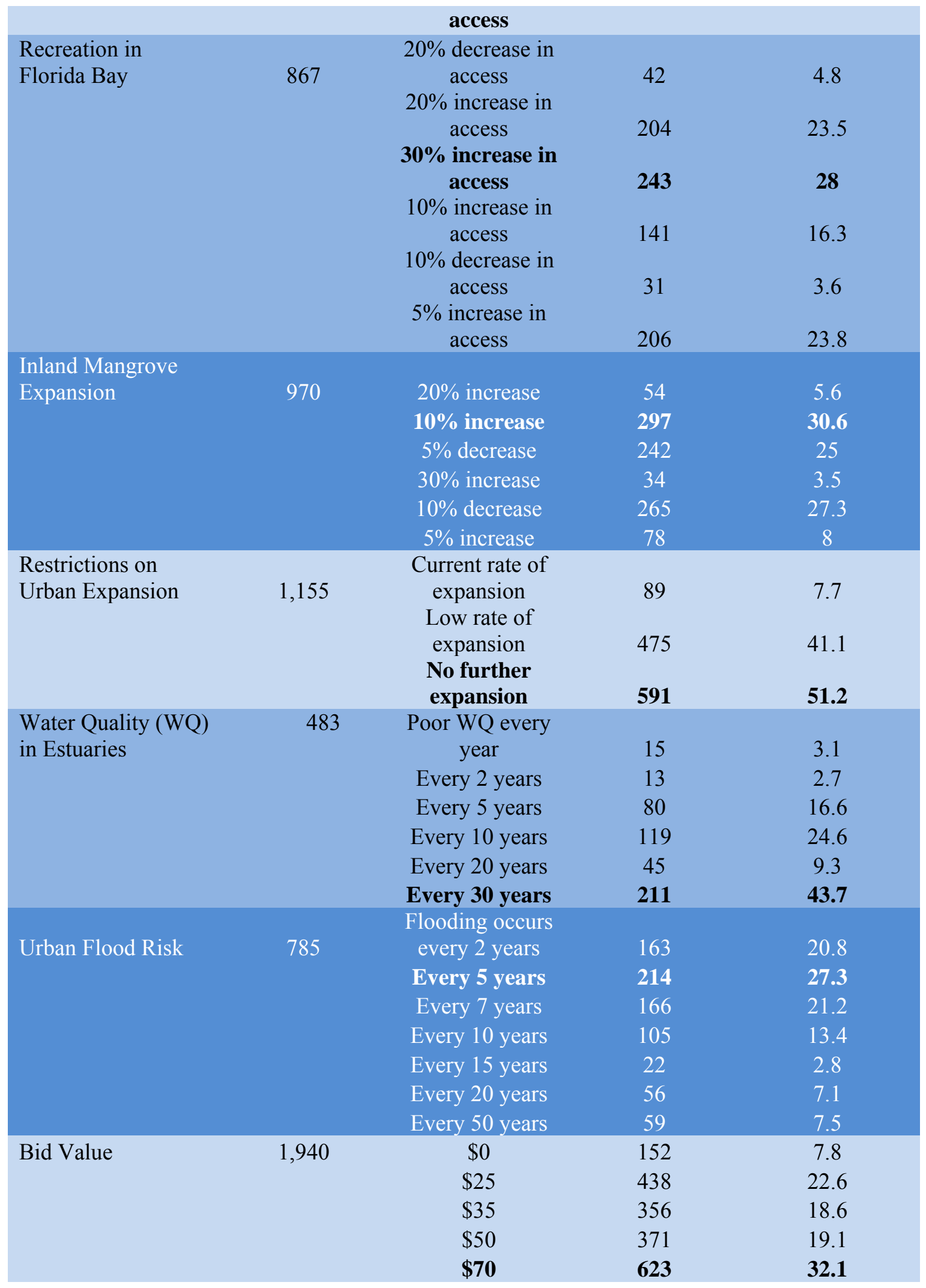




\subsubsection{Management Plan Attribute Selection by Level- Saltwater Anglers}

Table 4.6 displays the frequency of the level selection by attribute for the management plan choice cards in the saltwater angler sample. Again, the respondents chose only a $\mathbf{2 0} \%$ decrease in fish abundance (35.5\% favorability) in response to increased water levels in Lake Okeechobee. Also comparable to the general public choices, most respondents in this sample favored the "no unmet demands" option in terms of agricultural water demands (41.7\%) and municipal water supplies (44.2\%). However, respondents in the saltwater angler sample supported lower access to recreation activities in the Everglades National Park and Florida Bay, with $\mathbf{2 7 . 8 \%}$ of respondents supporting a $10 \%$ increase in access in the ENP and $29.5 \%$ supporting a $5 \%$ increase in access in Florida Bay. 37.4\% of respondents supported a $10 \%$ increase in inland mangrove expansion and $47.5 \%$ of respondents supported a "low rate of expansion" with regards to restriction on urban expansion. This result contrasts with the high support in the general public population of "no further expansion." However, saltwater anglers did support a higher urban flood risk at flooding every 5 years $(27.5 \%$ favorability) in order to gain higher water quality within the estuaries with poor water quality occurring every 30 years (37.2\%). This finding is consistent with the majority support within the general public sample population. Finally, the majority of respondents (27.9\%) were only willing to pay $\$ 25$ for these management plan components, while the majority of respondents in the general public were willing to pay the highest amount of $\$ 70$. However, the $\$ 70$ amount in the saltwater angler sample was the $2^{\text {nd }}$ highest favorable level with a very close $\mathbf{2 5 . 5 \%}$ of respondents willing to pay for plans of that price. 
Table 4.6: Choice Selection Frequency for Management Plan AttributesSaltwater Anglers

Saltwater Anglers Respondents: Management Plan Attribute Frequency Table

\begin{tabular}{|c|c|c|c|c|}
\hline Attribute Name & $\begin{array}{l}\text { Attribute } \\
\text { Frequency } \\
\text { Total }\end{array}$ & Attribute Levels & $\begin{array}{c}\text { Attribute } \\
\text { Level } \\
\text { Frequency }\end{array}$ & $\begin{array}{l}\text { Attribute Level } \\
\text { Frequency (\%) }\end{array}$ \\
\hline \multirow{7}{*}{$\begin{array}{l}\text { Water Levels in } \\
\text { Lake Okeechobee }\end{array}$} & \multirow{7}{*}{425} & No change in fish & & \\
\hline & & $\begin{array}{c}\text { abundance } \\
20 \% \text { decrease in }\end{array}$ & 34 & 8 \\
\hline & & fish abundance & 150 & 35.3 \\
\hline & & & 33 & 7.8 \\
\hline & & $60 \%$ decrease in & & \\
\hline & & fish abundance & 124 & 29.2 \\
\hline & & $\begin{array}{l}80 \% \text { decrease in } \\
\text { fish abundance }\end{array}$ & 84 & 19.8 \\
\hline \multirow{6}{*}{$\begin{array}{l}\text { Agricultural Water } \\
\text { Demands }\end{array}$} & \multirow{6}{*}{713} & No unmet & & \\
\hline & & demands & 297 & 41.7 \\
\hline & & $\begin{array}{c}5 \% \text { demands not } \\
\text { met } \\
10 \% \text { demands }\end{array}$ & 128 & 18 \\
\hline & & not met & 247 & 34.6 \\
\hline & & $\begin{array}{l}20 \% \text { demands not } \\
\text { met }\end{array}$ & 17 & 2.4 \\
\hline & & $\begin{array}{l}30 \% \text { demands not } \\
\text { met }\end{array}$ & 24 & 3.4 \\
\hline \multirow[t]{5}{*}{$\begin{array}{l}\text { Municipal Water } \\
\text { Supply }\end{array}$} & \multirow[t]{5}{*}{1,011} & $10 \%$ decrease & 50 & 5 \\
\hline & & $\begin{array}{l}10 \% \text { increase } \\
\text { No unmet }\end{array}$ & 285 & 28.2 \\
\hline & & demands & 447 & 44.2 \\
\hline & & $15 \%$ decrease & 28 & 2.8 \\
\hline & & $5 \%$ increase & 201 & 20 \\
\hline \multirow{7}{*}{$\begin{array}{l}\text { Recreation in } \\
\text { Everglades National } \\
\text { Park }\end{array}$} & \multirow{7}{*}{965} & & & \\
\hline & & $\begin{array}{l}20 \% \text { decrease in } \\
\text { access }\end{array}$ & 23 & 2.4 \\
\hline & & access & 220 & 22.8 \\
\hline & & $\begin{array}{c}30 \% \text { increase in } \\
\text { access } \\
\mathbf{1 0 \%} \text { increase in }\end{array}$ & 151 & 15.7 \\
\hline & & $\begin{array}{c}\text { access } \\
10 \% \text { decrease in }\end{array}$ & 268 & 27.8 \\
\hline & & $\begin{array}{c}\text { access } \\
40 \% \text { increase in }\end{array}$ & 50 & 5.2 \\
\hline & & access & 253 & 26.2 \\
\hline
\end{tabular}




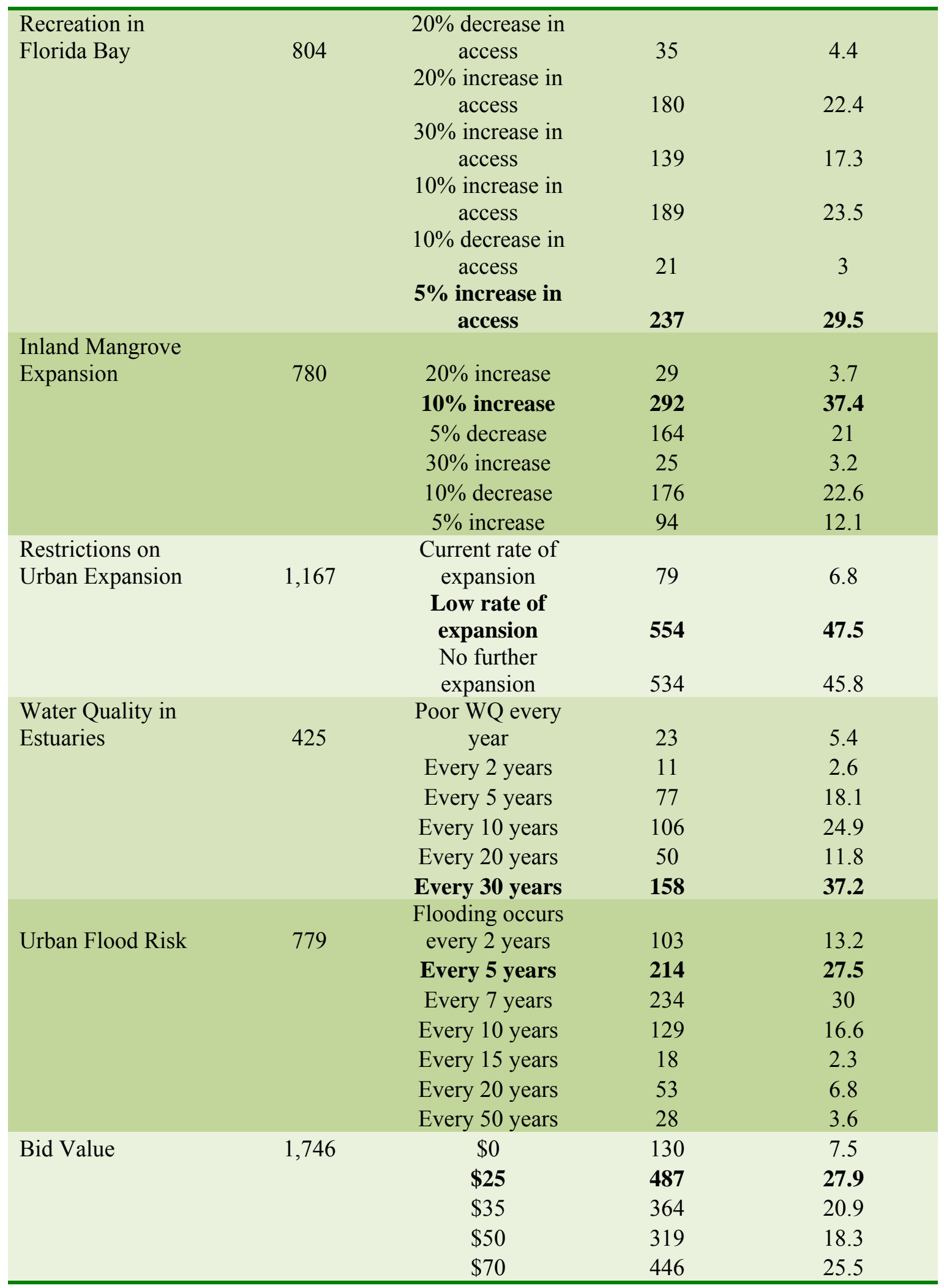




\subsection{Decisions by Choice Card and Sample Population}

4.4.1 Decisions by Individual Choice Cards for the Hydrological Model for the Milon et al. (1999) adapted choice cards

The following tables (Tables 4.7 to 4.10 ) display the attributes and levels of each choice card selected for this study and the preferred choice of all respondents within each sample population.

Table 4.7: Hydrological Model Choice Card Decisions: Cards 1- 5

\begin{tabular}{|c|c|c|c|c|c|c|c|c|c|c|}
\hline \multirow[t]{2}{*}{ Choice Card Identification } & \multicolumn{2}{|c|}{1} & \multicolumn{2}{|c|}{2} & \multicolumn{2}{|c|}{3} & \multicolumn{2}{|c|}{4} & \multicolumn{2}{|c|}{5} \\
\hline & $\begin{array}{l}\text { Plan } \\
\text { A }\end{array}$ & $\begin{array}{l}\text { Plan } \\
\text { B }\end{array}$ & $\begin{array}{l}\text { Plan } \\
\text { A }\end{array}$ & $\begin{array}{l}\text { Plan } \\
\text { B }\end{array}$ & $\begin{array}{l}\text { Plan } \\
\text { A }\end{array}$ & $\begin{array}{l}\text { Plan } \\
\text { B }\end{array}$ & $\begin{array}{l}\text { Plan } \\
\text { A }\end{array}$ & $\begin{array}{l}\text { Plan } \\
\text { B }\end{array}$ & $\begin{array}{l}\text { Plan } \\
\text { A }\end{array}$ & $\begin{array}{l}\text { Plan } \\
\text { B }\end{array}$ \\
\hline Lake Okeechobee & $60 \%$ & $60 \%$ & $60 \%$ & $75 \%$ & $60 \%$ & $75 \%$ & $60 \%$ & $90 \%$ & $60 \%$ & $60 \%$ \\
\hline Water Conservation Areas & $50 \%$ & $75 \%$ & $50 \%$ & $50 \%$ & $75 \%$ & $90 \%$ & $75 \%$ & $90 \%$ & $75 \%$ & $90 \%$ \\
\hline Everglades National Park & $50 \%$ & $90 \%$ & $50 \%$ & $90 \%$ & $90 \%$ & $90 \%$ & $50 \%$ & $90 \%$ & $50 \%$ & $90 \%$ \\
\hline Farmland Acreage & 0 & $\begin{array}{c}1000 \\
00\end{array}$ & 0 & $\begin{array}{c}1000 \\
00\end{array}$ & $\begin{array}{c}10000 \\
0\end{array}$ & $\begin{array}{c}2000 \\
00\end{array}$ & $\begin{array}{c}10000 \\
0\end{array}$ & $\begin{array}{c}2000 \\
00\end{array}$ & $\begin{array}{c}10000 \\
0\end{array}$ & $\begin{array}{c}2000 \\
00\end{array}$ \\
\hline $\begin{array}{l}\text { Restrictions on } \\
\text { Water Usage }\end{array}$ & $\begin{array}{r}1 \\
\text { day/ } \\
40 \%\end{array}$ & $\begin{array}{r}2 \\
\text { days/ } \\
25 \%\end{array}$ & $\begin{array}{r}1 \\
\text { day/ } \\
40 \%\end{array}$ & $\begin{array}{r}2 \\
\text { days/ } \\
25 \%\end{array}$ & $\begin{array}{r}2 \\
\text { days/ } \\
25 \%\end{array}$ & $\begin{array}{r}3 \\
\text { days/ } \\
10 \%\end{array}$ & $\begin{array}{r}2 \\
\text { days/ } \\
25 \%\end{array}$ & $\begin{array}{r}3 \\
\text { days/ } \\
10 \%\end{array}$ & $\begin{array}{r}2 \\
\text { days/ } \\
25 \%\end{array}$ & $\begin{array}{r}3 \\
\text { days/ } \\
10 \%\end{array}$ \\
\hline \multirow[t]{2}{*}{ Payment } & $\$ 0$ & $\$ 35$ & $\$ 0$ & $\$ 35$ & $\$ 35$ & $\$ 70$ & $\$ 35$ & $\$ 70$ & $\$ 35$ & $\$ 70$ \\
\hline & $\begin{array}{l}\text { Plan } \\
\text { A }\end{array}$ & $\begin{array}{l}\text { Plan } \\
\text { B }\end{array}$ & $\begin{array}{l}\text { Plan } \\
\text { A }\end{array}$ & $\begin{array}{l}\text { Plan } \\
\text { B }\end{array}$ & $\begin{array}{l}\text { Plan } \\
\text { A }\end{array}$ & $\begin{array}{l}\text { Plan } \\
\text { B }\end{array}$ & $\begin{array}{l}\text { Plan } \\
\text { A }\end{array}$ & $\begin{array}{l}\text { Plan } \\
\text { B }\end{array}$ & $\begin{array}{l}\text { Plan } \\
\text { A }\end{array}$ & $\begin{array}{l}\text { Plan } \\
\text { B }\end{array}$ \\
\hline $\begin{array}{l}\text { General Public- Preferred } \\
\text { Choice }\end{array}$ & $\begin{array}{c}34 \\
(1.67 \% \\
)\end{array}$ & $\begin{array}{l}65 \\
(3.20 \\
\%)\end{array}$ & $\begin{array}{l}43 \\
(2.12 \% \\
\quad)\end{array}$ & $\begin{array}{l}58 \\
(2.85 \\
\%)\end{array}$ & $\begin{array}{c}53 \\
(2.61 \% \\
\quad)\end{array}$ & $\begin{array}{l}46 \\
(1.23 \\
\%)\end{array}$ & $\begin{array}{c}41 \\
(2.02 \% \\
\quad)\end{array}$ & $\begin{array}{c}61 \\
(3.00 \\
\%)\end{array}$ & $\begin{array}{l}42 \\
(2.07 \% \\
\quad)\end{array}$ & $\begin{array}{c}62 \\
(3.05 \\
\%)\end{array}$ \\
\hline $\begin{array}{l}\text { General Public - Preferred } \\
\text { Choice Total }\end{array}$ & \multicolumn{2}{|c|}{$\begin{array}{c}99 \\
(4.87 \%)\end{array}$} & \multicolumn{2}{|c|}{$\begin{array}{c}95 \\
(4.66 \%)\end{array}$} & \multicolumn{2}{|c|}{$\begin{array}{c}99 \\
(4.87 \%)\end{array}$} & \multicolumn{2}{|c|}{$\begin{array}{c}102 \\
(5.02 \%)\end{array}$} & \multicolumn{2}{|c|}{$\begin{array}{c}104 \\
(5.12 \%)\end{array}$} \\
\hline $\begin{array}{l}\text { Saltwater Anglers- } \\
\text { Preferred Choice }\end{array}$ & $\begin{array}{c}11 \\
(1.26 \% \\
\quad)\end{array}$ & $\begin{array}{c}40 \\
(4.58 \\
\%)\end{array}$ & $\begin{array}{c}1 \\
(0.11 \% \\
\quad)\end{array}$ & $\begin{array}{c}43 \\
(4.93 \\
\%)\end{array}$ & $\begin{array}{l}17 \\
(1.95 \% \\
\quad)\end{array}$ & $\begin{array}{l}25 \\
(2.86 \\
\%)\end{array}$ & $\begin{array}{l}10 \\
(1.15 \% \\
\quad)\end{array}$ & $\begin{array}{l}26 \\
(2.98 \\
\%)\end{array}$ & $\begin{array}{c}12 \\
(1.37 \% \\
\quad)\end{array}$ & $\begin{array}{c}42 \\
(4.81 \\
\%)\end{array}$ \\
\hline $\begin{array}{l}\text { Saltwater Anglers- } \\
\text { Preferred Choice Total }\end{array}$ & \multicolumn{2}{|c|}{$\begin{array}{c}51 \\
(5.84 \%)\end{array}$} & \multicolumn{2}{|c|}{$\begin{array}{c}44 \\
(5.04 \%)\end{array}$} & \multicolumn{2}{|c|}{$\begin{array}{c}42 \\
(4.81 \%)\end{array}$} & \multicolumn{2}{|c|}{$\begin{array}{c}36 \\
(4.12 \%)\end{array}$} & \multicolumn{2}{|c|}{$\begin{array}{c}54 \\
(6.19 \%)\end{array}$} \\
\hline
\end{tabular}

In cards 1-5, respondents favored Plan A less than Plan B, which holds true across both sample populations, with the exception of Card 3 within the general public. With regards to Card 3, respondents preferred Plan A over Plan B likely due to the $\$ 70$ price of Plan B, with very small marginal differences between the levels of restoration. Within the 
saltwater angler sample population, respondents overwhelmingly favored Plan B with respect to Card 2, with only 1 respondent (or 0.11\%) choosing Plan A over B. Plan B in Card 2 represents a very standard partial restoration as it contains mostly levels common in partial restoration scenarios.

Table 4.8: Hydrological Model Choice Card Decisions: Cards 6- 10

\begin{tabular}{|c|c|c|c|c|c|c|c|c|c|c|}
\hline \multirow[t]{2}{*}{ Choice Card Identification } & \multicolumn{2}{|c|}{6} & \multicolumn{2}{|c|}{7} & \multicolumn{2}{|c|}{8} & \multicolumn{2}{|c|}{9} & \multicolumn{2}{|c|}{10} \\
\hline & $\begin{array}{l}\text { Plan } \\
\text { A }\end{array}$ & $\begin{array}{l}\text { Plan } \\
\text { B }\end{array}$ & $\begin{array}{l}\text { Plan } \\
\text { A }\end{array}$ & $\begin{array}{l}\text { Plan } \\
\text { B }\end{array}$ & $\begin{array}{l}\text { Plan } \\
\text { A }\end{array}$ & $\begin{array}{l}\text { Plan } \\
\text { B }\end{array}$ & $\begin{array}{l}\text { Plan } \\
\text { A }\end{array}$ & $\begin{array}{l}\text { Plan } \\
\text { B }\end{array}$ & $\begin{array}{l}\text { Plan } \\
\text { A }\end{array}$ & $\begin{array}{l}\text { Plan } \\
\text { B }\end{array}$ \\
\hline Lake Okeechobee & $60 \%$ & $90 \%$ & $75 \%$ & $90 \%$ & $75 \%$ & $90 \%$ & $75 \%$ & $75 \%$ & $75 \%$ & $75 \%$ \\
\hline Water Conservation Areas & $50 \%$ & $75 \%$ & $50 \%$ & $90 \%$ & $50 \%$ & $50 \%$ & $50 \%$ & $75 \%$ & $50 \%$ & $90 \%$ \\
\hline Everglades National Park & $75 \%$ & $75 \%$ & $75 \%$ & $75 \%$ & $50 \%$ & $75 \%$ & $50 \%$ & $90 \%$ & $50 \%$ & $75 \%$ \\
\hline Farmland Acreage & 0 & $\begin{array}{r}2000 \\
00 \\
\end{array}$ & $\begin{array}{r}10000 \\
0 \\
\end{array}$ & $\begin{array}{r}2000 \\
00 \\
\end{array}$ & $\begin{array}{r}10000 \\
0\end{array}$ & $\begin{array}{r}2000 \\
00 \\
\end{array}$ & 0 & $\begin{array}{r}2000 \\
00 \\
\end{array}$ & 0 & $\begin{array}{r}1000 \\
00 \\
\end{array}$ \\
\hline $\begin{array}{l}\text { Restrictions on } \\
\text { Water Usage }\end{array}$ & $\begin{array}{r}1 \\
\text { day/ } \\
40 \%\end{array}$ & $\begin{array}{r}3 \\
\text { days/ } \\
10 \% \\
\end{array}$ & $\begin{array}{r}2 \\
\text { days/ } \\
25 \%\end{array}$ & $\begin{array}{r}3 \\
\text { days/ } \\
10 \%\end{array}$ & $\begin{array}{r}3 \\
\text { days/ } \\
10 \%\end{array}$ & $\begin{array}{r}2 \\
\text { days/ } \\
25 \% \\
\end{array}$ & $\begin{array}{r}2 \\
\text { days/ } \\
25 \%\end{array}$ & $\begin{array}{r}3 \\
\text { days/ } \\
10 \%\end{array}$ & $\begin{array}{r}1 \\
\text { day/ } \\
40 \%\end{array}$ & $\begin{array}{r}2 \\
\text { days/ } \\
25 \% \\
\end{array}$ \\
\hline \multirow[t]{2}{*}{ Payment } & $\$ 0$ & $\$ 70$ & $\$ 35$ & $\$ 70$ & $\$ 35$ & $\$ 70$ & $\$ 35$ & $\$ 70$ & $\$ 0$ & $\$ 35$ \\
\hline & $\begin{array}{l}\text { Plan } \\
\text { A }\end{array}$ & $\begin{array}{l}\text { Plan } \\
\text { B }\end{array}$ & $\begin{array}{l}\text { Plan } \\
\text { A }\end{array}$ & $\begin{array}{l}\text { Plan } \\
\text { B }\end{array}$ & $\begin{array}{l}\text { Plan } \\
\text { A }\end{array}$ & $\begin{array}{l}\text { Plan } \\
\text { B }\end{array}$ & $\begin{array}{l}\text { Plan } \\
\text { A }\end{array}$ & $\begin{array}{l}\text { Plan } \\
\text { B }\end{array}$ & $\begin{array}{l}\text { Plan } \\
\text { A }\end{array}$ & $\begin{array}{l}\text { Plan } \\
\text { B }\end{array}$ \\
\hline $\begin{array}{l}\text { General Public- Preferred } \\
\text { Choice }\end{array}$ & $\begin{array}{c}46 \\
(2.26 \% \\
)\end{array}$ & $\begin{array}{c}63 \\
(3.10 \\
\%)\end{array}$ & $\begin{array}{c}50 \\
(2.46 \% \\
\quad)\end{array}$ & $\begin{array}{c}59 \\
(2.90 \\
\%)\end{array}$ & $\begin{array}{c}61 \\
(3.00 \% \\
\quad)\end{array}$ & $\begin{array}{c}40 \\
(1.97 \\
\%)\end{array}$ & $\begin{array}{c}48 \\
(2.36 \% \\
\quad)\end{array}$ & $\begin{array}{c}58 \\
(2.85 \\
\%)\end{array}$ & $\begin{array}{c}33 \\
(1.62 \% \\
)\end{array}$ & $\begin{array}{c}71 \\
(3.49 \\
\%)\end{array}$ \\
\hline $\begin{array}{l}\text { General Public - Preferred } \\
\text { Choice Total }\end{array}$ & \multicolumn{2}{|c|}{$\begin{array}{c}109 \\
(5.71 \%)\end{array}$} & \multicolumn{2}{|c|}{$\begin{array}{c}109 \\
(5.36 \%)\end{array}$} & \multicolumn{2}{|c|}{$\begin{array}{c}101 \\
(4.97 \%)\end{array}$} & \multicolumn{2}{|c|}{$\begin{array}{c}106 \\
(5.22 \%)\end{array}$} & \multicolumn{2}{|c|}{$\begin{array}{c}104 \\
(5.12 \%)\end{array}$} \\
\hline $\begin{array}{l}\text { Saltwater Anglers- } \\
\text { Preferred Choice }\end{array}$ & $\begin{array}{c}6 \\
(0.69 \% \\
\quad)\end{array}$ & $\begin{array}{c}36 \\
(4.12 \\
\%)\end{array}$ & $\begin{array}{c}12 \\
(1.37 \% \\
)\end{array}$ & $\begin{array}{c}26 \\
(2.98 \\
\%)\end{array}$ & $\begin{array}{c}14 \\
(1.60)\end{array}$ & $\begin{array}{c}30 \\
(3.44 \\
\%)\end{array}$ & $\begin{array}{c}13 \\
(1.49 \% \\
)\end{array}$ & $\begin{array}{c}35 \\
(4.01 \\
\%)\end{array}$ & $\begin{array}{c}5 \\
(0.57 \% \\
\quad)\end{array}$ & $\begin{array}{c}34 \\
(3.89 \\
\%)\end{array}$ \\
\hline $\begin{array}{l}\text { Saltwater Anglers- } \\
\text { Preferred Choice Total }\end{array}$ & & \multicolumn{2}{|c|}{$\begin{array}{c}38 \\
(4.35 \%)\end{array}$} & \multicolumn{2}{|c|}{$\begin{array}{c}44 \\
(5.04 \%)\end{array}$} & \multicolumn{2}{|c|}{$\begin{array}{c}48 \\
(5.50 \%)\end{array}$} & \multicolumn{2}{|c|}{$\begin{array}{c}39 \\
(4.47 \%)\end{array}$} \\
\hline
\end{tabular}

Within Cards 6- 10, most respondents in both sample populations chose Plan B over Plan A, with the exception of Card 8 amongst general public respondents. Respondents likely preferred Plan A over Plan in Card 8 due to the higher price (\$70) of Plan B and the lower amounts of water restrictions associated with Plan A. However, in the saltwater 
anglers sample population Plan A in Card 6 and Card 10 elicited very low favorability $(0.69 \%$ and $0.57 \%$, respectively).

Table 4.9: Hydrological Model Choice Card Decisions: Cards 11-15

\begin{tabular}{|c|c|c|c|c|c|c|c|c|c|c|}
\hline \multirow{2}{*}{$\begin{array}{l}\text { Choice Card } \\
\text { Identification }\end{array}$} & \multicolumn{2}{|c|}{11} & \multicolumn{2}{|c|}{12} & \multicolumn{2}{|c|}{13} & \multicolumn{2}{|c|}{14} & \multicolumn{2}{|c|}{15} \\
\hline & $\begin{array}{l}\text { Plan } \\
\text { A }\end{array}$ & $\begin{array}{l}\text { Plan } \\
\text { B }\end{array}$ & Plan A & $\begin{array}{l}\text { Plan } \\
\text { B }\end{array}$ & Plan A & $\begin{array}{l}\text { Plan } \\
\text { B }\end{array}$ & Plan A & $\begin{array}{l}\text { Plan } \\
\text { B }\end{array}$ & Plan A & $\begin{array}{l}\text { Plan } \\
\text { B }\end{array}$ \\
\hline Lake Okeechobee & $75 \%$ & $90 \%$ & $60 \%$ & $90 \%$ & $60 \%$ & $75 \%$ & $75 \%$ & $90 \%$ & $75 \%$ & $75 \%$ \\
\hline $\begin{array}{l}\text { Water } \\
\text { Conservation } \\
\text { Areas }\end{array}$ & $50 \%$ & $75 \%$ & $75 \%$ & $90 \%$ & $50 \%$ & $75 \%$ & $50 \%$ & $90 \%$ & $75 \%$ & $90 \%$ \\
\hline $\begin{array}{l}\text { Everglades } \\
\text { National Park }\end{array}$ & $50 \%$ & $75 \%$ & $90 \%$ & $75 \%$ & $75 \%$ & $90 \%$ & $90 \%$ & $75 \%$ & $50 \%$ & $50 \%$ \\
\hline $\begin{array}{l}\text { Farmland } \\
\text { Acreage }\end{array}$ & 0 & $\begin{array}{r}20000 \\
0 \\
\end{array}$ & 0 & $\begin{array}{l}1000 \\
00\end{array}$ & 100000 & $\begin{array}{r}1000 \\
00\end{array}$ & 100000 & $\begin{array}{r}2000 \\
00 \\
\end{array}$ & 0 & $\begin{array}{r}2000 \\
00 \\
\end{array}$ \\
\hline $\begin{array}{l}\text { Restrictions on } \\
\text { Water Usage }\end{array}$ & $\begin{array}{r}1 \\
\text { day/ } \\
40 \%\end{array}$ & $\begin{array}{r}3 \\
\text { days/ } \\
10 \%\end{array}$ & $\begin{array}{r}1 \\
\text { day/ } \\
40 \%\end{array}$ & $\begin{array}{r}2 \\
\text { days/ } \\
25 \% \\
\end{array}$ & $\begin{array}{r}1 \\
\text { day/ } \\
40 \%\end{array}$ & $\begin{array}{r}1 \\
\text { day/ } \\
40 \% \\
\end{array}$ & $\begin{array}{r}2 \\
\text { days/ } \\
25 \%\end{array}$ & $\begin{array}{r}3 \\
\text { days/ } \\
10 \% \\
\end{array}$ & $\begin{array}{r}1 \\
\text { day/ } \\
40 \%\end{array}$ & $\begin{array}{r}2 \\
\text { days/ } \\
25 \%\end{array}$ \\
\hline \multirow[t]{2}{*}{ Payment } & $\$ 0$ & $\$ 70$ & $\$ 0$ & $\$ 35$ & $\$ 35$ & $\$ 70$ & $\$ 35$ & $\$ 70$ & $\$ 0$ & $\$ 70$ \\
\hline & $\begin{array}{l}\text { Plan } \\
\text { A }\end{array}$ & $\begin{array}{l}\text { Plan } \\
\text { B }\end{array}$ & Plan A & $\begin{array}{l}\text { Plan } \\
\text { B }\end{array}$ & Plan A & $\begin{array}{l}\text { Plan } \\
\text { B }\end{array}$ & Plan A & $\begin{array}{l}\text { Plan } \\
\text { B }\end{array}$ & Plan A & $\begin{array}{l}\text { Plan } \\
\text { B }\end{array}$ \\
\hline $\begin{array}{l}\text { General Public- } \\
\text { Preferred Choice }\end{array}$ & $\begin{array}{c}35 \\
(1.72 \\
\%)\end{array}$ & $\begin{array}{c}63 \\
(3.10 \\
\%)\end{array}$ & $\begin{array}{c}38 \\
(1.87 \%)\end{array}$ & $\begin{array}{c}63 \\
(3.10 \\
\%)\end{array}$ & $\begin{array}{c}40 \\
(1.97 \%)\end{array}$ & $\begin{array}{c}55 \\
(3.10 \\
\%)\end{array}$ & $\begin{array}{c}40 \\
(1.97 \%)\end{array}$ & $\begin{array}{c}57 \\
(2.81 \\
\%)\end{array}$ & $\begin{array}{c}42 \\
(2.07 \%)\end{array}$ & $\begin{array}{c}64 \\
(3.15 \\
\%)\end{array}$ \\
\hline $\begin{array}{l}\text { General Public - } \\
\text { Preferred Choice } \\
\text { Total }\end{array}$ & \multicolumn{2}{|c|}{$\begin{array}{c}98 \\
(4.84 \%)\end{array}$} & \multicolumn{2}{|c|}{$\begin{array}{c}101 \\
(4.97 \%)\end{array}$} & \multicolumn{2}{|c|}{$\begin{array}{c}95 \\
(4.66 \%)\end{array}$} & \multicolumn{2}{|c|}{$\begin{array}{c}97 \\
(4.77 \%)\end{array}$} & \multicolumn{2}{|c|}{$\begin{array}{c}106 \\
(5.22 \%)\end{array}$} \\
\hline $\begin{array}{l}\text { Saltwater } \\
\text { Anglers- } \\
\text { Preferred Choice }\end{array}$ & $\begin{array}{c}6 \\
(0.69 \\
\%)\end{array}$ & $\begin{array}{l}35 \\
(4.01 \\
\%)\end{array}$ & $\begin{array}{c}11 \\
(1.26 \%)\end{array}$ & $\begin{array}{c}35 \\
(4.01 \\
\%)\end{array}$ & $\begin{array}{c}10 \\
(1.15 \%)\end{array}$ & $\begin{array}{c}35 \\
(4.01 \\
\%)\end{array}$ & $\begin{array}{c}18 \\
(2.06 \%)\end{array}$ & $\begin{array}{c}23 \\
(2.63 \\
\%)\end{array}$ & $\begin{array}{c}13 \\
(1.49 \%)\end{array}$ & $\begin{array}{c}27 \\
(3.09 \\
\%)\end{array}$ \\
\hline $\begin{array}{l}\text { Saltwater } \\
\text { Anglers- } \\
\text { Preferred Choice } \\
\text { Total }\end{array}$ & \multicolumn{2}{|c|}{$\begin{array}{l}41 \\
.70 \%)\end{array}$} & \multicolumn{2}{|c|}{$\begin{array}{c}46 \\
(5.27 \%)\end{array}$} & \multicolumn{2}{|c|}{$\begin{array}{c}45 \\
(5.15 \%)\end{array}$} & \multicolumn{2}{|c|}{$\begin{array}{c}41 \\
(4.70 \%)\end{array}$} & \multicolumn{2}{|c|}{$\begin{array}{c}40 \\
(4.58 \%)\end{array}$} \\
\hline
\end{tabular}

Again, within cards 11-15, respondents favored Plan B in each card within both sample populations. However, the favorability for Card 14 within the saltwater anglers sample population was not as pronounced, with $2.06 \%$ of respondents favoring Plan A and $2.63 \%$ of respondents favoring Plan B. This outcome likely resulted from the higher 
levels of restoration within Plan A, therefore leading to lower marginal increases of restoration in Plan B.

Table 4.10: Hydrological Model Choice Card Decisions: Cards 16-20

\begin{tabular}{|c|c|c|c|c|c|c|c|c|c|c|}
\hline \multirow[t]{2}{*}{ Choice Card Identification } & \multicolumn{2}{|c|}{16} & \multicolumn{2}{|c|}{17} & \multicolumn{2}{|c|}{18} & \multicolumn{2}{|c|}{19} & \multicolumn{2}{|c|}{20} \\
\hline & $\begin{array}{l}\text { Plan } \\
\text { A }\end{array}$ & $\begin{array}{l}\text { Plan } \\
\text { B }\end{array}$ & Plan A & $\begin{array}{l}\text { Plan } \\
\text { B }\end{array}$ & $\begin{array}{l}\text { Plan } \\
\text { A }\end{array}$ & $\begin{array}{l}\text { Plan } \\
\text { B }\end{array}$ & $\begin{array}{l}\text { Plan } \\
\text { A }\end{array}$ & $\begin{array}{l}\text { Plan } \\
\text { B }\end{array}$ & $\begin{array}{l}\text { Plan } \\
\text { A }\end{array}$ & $\begin{array}{l}\text { Plan } \\
\text { B }\end{array}$ \\
\hline Lake Okeechobee & $75 \%$ & $90 \%$ & $60 \%$ & $60 \%$ & $60 \%$ & $75 \%$ & $75 \%$ & $90 \%$ & $90 \%$ & $90 \%$ \\
\hline Water Conservation Areas & $50 \%$ & $90 \%$ & $50 \%$ & $90 \%$ & $75 \%$ & $50 \%$ & $90 \%$ & $90 \%$ & $75 \%$ & $90 \%$ \\
\hline Everglades National Park & $90 \%$ & $75 \%$ & $50 \%$ & $75 \%$ & $50 \%$ & $75 \%$ & $50 \%$ & $75 \%$ & $75 \%$ & $90 \%$ \\
\hline Farmland Acreage & $\begin{array}{r}10000 \\
0\end{array}$ & $\begin{array}{r}2000 \\
00\end{array}$ & 0 & $\begin{array}{r}1000 \\
00\end{array}$ & 0 & $\begin{array}{r}1000 \\
00\end{array}$ & 0 & $\begin{array}{r}1000 \\
00\end{array}$ & 0 & $\begin{array}{r}10000 \\
0\end{array}$ \\
\hline $\begin{array}{l}\text { Restrictions on } \\
\text { Water Usage }\end{array}$ & $\begin{array}{r}2 \\
\text { days/ } \\
25 \%\end{array}$ & $\begin{array}{r}2 \\
\text { days/ } \\
25 \%\end{array}$ & $\begin{array}{r}2 \\
\text { days/ } \\
25 \%\end{array}$ & $\begin{array}{r}3 \\
\text { days/ } \\
10 \%\end{array}$ & $\begin{array}{r}1 \\
\text { day/ } \\
40 \%\end{array}$ & $\begin{array}{r}2 \\
\text { days/ } \\
25 \%\end{array}$ & $\begin{array}{r}1 \\
\text { day/ } \\
40 \%\end{array}$ & $\begin{array}{r}3 \\
\text { days/ } \\
10 \%\end{array}$ & $\begin{array}{r}2 \\
\text { days/ } \\
25 \%\end{array}$ & $\begin{array}{r}2 \\
\text { days/ } \\
25 \%\end{array}$ \\
\hline \multirow[t]{2}{*}{ Payment } & $\$ 35$ & $\$ 70$ & $\$ 0$ & $\$ 35$ & $\$ 0$ & $\$ 35$ & $\$ 0$ & $\$ 35$ & $\$ 0$ & $\$ 35$ \\
\hline & $\begin{array}{l}\text { Plan } \\
\text { A }\end{array}$ & $\begin{array}{l}\text { Plan } \\
\text { B }\end{array}$ & Plan A & $\begin{array}{l}\text { Plan } \\
\text { B }\end{array}$ & $\begin{array}{l}\text { Plan } \\
\text { A }\end{array}$ & $\begin{array}{l}\text { Plan } \\
\text { B }\end{array}$ & $\begin{array}{l}\text { Plan } \\
\text { A }\end{array}$ & $\begin{array}{l}\text { Plan } \\
\text { B }\end{array}$ & $\begin{array}{l}\text { Plan } \\
\text { A }\end{array}$ & $\begin{array}{l}\text { Plan } \\
\text { B }\end{array}$ \\
\hline $\begin{array}{l}\text { General Public- Preferred } \\
\text { Choice }\end{array}$ & $\begin{array}{c}69 \\
(3.40 \% \\
)\end{array}$ & $\begin{array}{c}41 \\
(2.02 \\
\%)\end{array}$ & $\begin{array}{c}46 \\
(2.26 \% \\
)\end{array}$ & $\begin{array}{c}56 \\
(2.76 \\
\%)\end{array}$ & $\begin{array}{c}45 \\
(2.21 \% \\
)\end{array}$ & $\begin{array}{c}43 \\
(2.12 \\
\%)\end{array}$ & $\begin{array}{c}36 \\
(1.77 \% \\
\quad)\end{array}$ & $\begin{array}{c}62 \\
(3.05 \\
\%)\end{array}$ & $\begin{array}{c}42 \\
(2.07 \% \\
\quad)\end{array}$ & $\begin{array}{c}63 \\
(3.10 \% \\
)\end{array}$ \\
\hline $\begin{array}{l}\text { General Public - Preferred } \\
\text { Choice Total }\end{array}$ & \multicolumn{2}{|c|}{$\begin{array}{c}110 \\
(5.41 \%)\end{array}$} & \multicolumn{2}{|c|}{$\begin{array}{c}108 \\
(5.02 \%)\end{array}$} & \multicolumn{2}{|c|}{$\begin{array}{c}88 \\
(4.33 \%)\end{array}$} & \multicolumn{2}{|c|}{$\begin{array}{c}101 \\
(4.82 \%)\end{array}$} & \multicolumn{2}{|c|}{$\begin{array}{c}105 \\
(5.17 \%)\end{array}$} \\
\hline $\begin{array}{l}\text { Saltwater Anglers- } \\
\text { Preferred Choice }\end{array}$ & $\begin{array}{c}17 \\
(1.95 \% \\
)\end{array}$ & $\begin{array}{c}24 \\
(2.75 \\
\%)\end{array}$ & $\begin{array}{c}7 \\
(0.80 \% \\
)\end{array}$ & $\begin{array}{c}37 \\
(4.24 \\
\%)\end{array}$ & $\begin{array}{c}12 \\
(1.37 \% \\
)\end{array}$ & $\begin{array}{c}31 \\
(3.55 \\
\%)\end{array}$ & $\begin{array}{c}13 \\
(1.49 \% \\
)\end{array}$ & $\begin{array}{c}35 \\
(4.01 \\
\%)\end{array}$ & $\begin{array}{c}11 \\
(1.26 \% \\
)\end{array}$ & $\begin{array}{c}35 \\
(4.01 \% \\
)\end{array}$ \\
\hline $\begin{array}{l}\text { Saltwater Anglers- } \\
\text { Preferred Choice Total }\end{array}$ & \multicolumn{2}{|c|}{$\begin{array}{c}41 \\
(4.70 \%)\end{array}$} & \multicolumn{2}{|c|}{$\begin{array}{c}44 \\
(5.04 \%)\end{array}$} & \multicolumn{2}{|c|}{$\begin{array}{c}44 \\
(5.04 \%)\end{array}$} & \multicolumn{2}{|c|}{$\begin{array}{c}48 \\
(5.50 \%)\end{array}$} & \multicolumn{2}{|c|}{$\begin{array}{c}46 \\
(5.27 \%)\end{array}$} \\
\hline Subtotal & \multicolumn{6}{|c|}{$\begin{array}{c}\text { General Public } \\
\text { Plan A: } 882(43.41 \%) \\
\text { Plan B: 1,150 (56.59\%) } \\
\text { n = 2,032 }\end{array}$} & \multicolumn{4}{|c|}{$\begin{array}{c}\text { Saltwater Anglers } \\
\text { Plan A: } 219(25.09 \%) \\
\text { Plan B: } 654(74.91 \%) \\
\text { n = 873 }\end{array}$} \\
\hline
\end{tabular}

Finally, within Cards 16-20, respondents within the saltwater anglers sample population continued to favor Plan B over Plan A across all cards. However, in the general public sample, respondents favored Plan A over Plan B within Card 16 and 18. Plan A in Card 18 did not elicit a much higher preference over Plan B. Yet, in Card 16, despite the higher levels of hydrological restoration in Plan B, the presence of the same water level restrictions in both Plan A and B may have caused favorability to shift towards Plan A. 
In the saltwater anglers sample population, only $2.75 \%$ of respondents favored Plan B, while $1.95 \%$ of respondents favored Plan A. This result was likely due to the high restoration levels in Plan A priced at \$35, while only marginally higher levels of restoration in Plan B cost double the price of Plan A. Overall, 56.6\% of respondents in the general public population favored Plan B across all choice card combinations, and a higher amount of respondents, $74.9 \%$ of respondents in the saltwater anglers group responded in the same fashion.

4.4.2. Decisions by Individual Choice Cards for the Species Model for the Milon et al. (1999) adapted choice cards

Table 4.11: Species Model Choice Card Decisions: Cards 21-25

\begin{tabular}{|c|c|c|c|c|c|c|c|c|c|c|}
\hline \multirow[t]{2}{*}{ Choice Card Identification } & \multicolumn{2}{|c|}{21} & \multicolumn{2}{|c|}{22} & \multicolumn{2}{|c|}{23} & \multicolumn{2}{|c|}{24} & \multicolumn{2}{|c|}{25} \\
\hline & $\begin{array}{l}\text { Plan } \\
\text { A }\end{array}$ & $\begin{array}{l}\text { Plan } \\
\text { B }\end{array}$ & $\begin{array}{l}\text { Plan } \\
\text { A }\end{array}$ & $\begin{array}{l}\text { Plan } \\
\text { B }\end{array}$ & $\begin{array}{l}\text { Plan } \\
\text { A }\end{array}$ & $\begin{array}{l}\text { Plan } \\
\text { B }\end{array}$ & $\begin{array}{l}\text { Plan } \\
\text { A }\end{array}$ & $\begin{array}{l}\text { Plan } \\
\text { B }\end{array}$ & $\begin{array}{l}\text { Plan } \\
\text { A }\end{array}$ & $\begin{array}{l}\text { Plan } \\
\text { B }\end{array}$ \\
\hline Wetland Species & $20 \%$ & $20 \%$ & $20 \%$ & $50 \%$ & $20 \%$ & $80 \%$ & $20 \%$ & $80 \%$ & $20 \%$ & $50 \%$ \\
\hline Dry land Species & $50 \%$ & $65 \%$ & $50 \%$ & $75 \%$ & $50 \%$ & $65 \%$ & $50 \%$ & $75 \%$ & $65 \%$ & $50 \%$ \\
\hline Florida Bay Species & $60 \%$ & $90 \%$ & $60 \%$ & $60 \%$ & $60 \%$ & $75 \%$ & $60 \%$ & $90 \%$ & $90 \%$ & $90 \%$ \\
\hline Farmland Acreage & $\begin{array}{r}10000 \\
0\end{array}$ & $\begin{array}{r}2000 \\
00\end{array}$ & 0 & $\begin{array}{r}2000 \\
00\end{array}$ & $\begin{array}{r}1000 \\
00\end{array}$ & $\begin{array}{r}2000 \\
00\end{array}$ & $\begin{array}{r}1000 \\
00\end{array}$ & $\begin{array}{r}1000 \\
00\end{array}$ & $\begin{array}{r}10000 \\
0\end{array}$ & $\begin{array}{r}2000 \\
00\end{array}$ \\
\hline Restrictions on Water Usage & $\begin{array}{r}2 \\
\text { days/ } \\
25 \%\end{array}$ & $\begin{array}{r}3 \\
\text { days/ } \\
10 \%\end{array}$ & $\begin{array}{r}1 \\
\text { day/ } \\
40 \%\end{array}$ & $\begin{array}{r}2 \\
\text { days/ } \\
25 \% \\
\end{array}$ & $\begin{array}{r}2 \\
\text { days/ } \\
25 \% \\
\end{array}$ & $\begin{array}{r}3 \\
\text { days/ } \\
10 \% \\
\end{array}$ & $\begin{array}{r}2 \\
\text { days/ } \\
25 \%\end{array}$ & $\begin{array}{r}3 \\
\text { days/ } \\
10 \% \\
\end{array}$ & $\begin{array}{r}1 \\
\text { day/ } \\
40 \%\end{array}$ & $\begin{array}{r}3 \\
\text { days/ } \\
10 \%\end{array}$ \\
\hline \multirow[t]{2}{*}{ Payment } & $\$ 35$ & $\$ 70$ & $\$ 0$ & $\$ 35$ & $\$ 35$ & $\$ 70$ & $\$ 35$ & $\$ 70$ & $\$ 35$ & $\$ 70$ \\
\hline & $\begin{array}{l}\text { Plan } \\
\text { A }\end{array}$ & $\begin{array}{l}\text { Plan } \\
\text { B }\end{array}$ & $\begin{array}{l}\text { Plan } \\
\text { A }\end{array}$ & $\begin{array}{l}\text { Plan } \\
\text { B }\end{array}$ & $\begin{array}{l}\text { Plan } \\
\text { A }\end{array}$ & $\begin{array}{l}\text { Plan } \\
\text { B }\end{array}$ & $\begin{array}{l}\text { Plan } \\
\text { A }\end{array}$ & $\begin{array}{l}\text { Plan } \\
\text { B }\end{array}$ & $\begin{array}{l}\text { Plan } \\
\text { A }\end{array}$ & $\begin{array}{l}\text { Plan } \\
\text { B }\end{array}$ \\
\hline $\begin{array}{l}\text { General Public- Preferred } \\
\text { Choice }\end{array}$ & $\begin{array}{c}37 \\
(1.82 \% \\
\quad)\end{array}$ & $\begin{array}{c}54 \\
(2.66 \\
\%)\end{array}$ & $\begin{array}{c}26 \\
(1.18 \% \\
\quad)\end{array}$ & $\begin{array}{c}75 \\
(3.89 \\
\%)\end{array}$ & $\begin{array}{c}44 \\
(2.17 \\
\%)\end{array}$ & $\begin{array}{c}61 \\
(3.00 \\
\%)\end{array}$ & $\begin{array}{c}40 \\
(2.85 \\
\%)\end{array}$ & $\begin{array}{c}61 \\
(4.53 \\
\%)\end{array}$ & $\begin{array}{l}57 \\
(2.81 \% \\
\quad)\end{array}$ & $\begin{array}{l}49 \\
(2.41 \\
\%)\end{array}$ \\
\hline $\begin{array}{l}\text { General Public - Preferred } \\
\text { Choice Total }\end{array}$ & \multicolumn{2}{|c|}{$\begin{array}{c}91 \\
(4.48 \%)\end{array}$} & \multicolumn{2}{|c|}{$\begin{array}{c}101 \\
(4.97 \%)\end{array}$} & \multicolumn{2}{|c|}{$\begin{array}{c}105 \\
(5.17 \%)\end{array}$} & \multicolumn{2}{|c|}{$\begin{array}{c}101 \\
(4.97 \%)\end{array}$} & \multicolumn{2}{|c|}{$\begin{array}{c}106 \\
(5.21 \%)\end{array}$} \\
\hline $\begin{array}{l}\text { Saltwater Anglers- Preferred } \\
\text { Choice }\end{array}$ & $\begin{array}{c}18 \\
(2.06 \% \\
\quad)\end{array}$ & $\begin{array}{c}24 \\
(2.75 \\
\%)\end{array}$ & $\begin{array}{c}8 \\
(0.92 \% \\
)\end{array}$ & $\begin{array}{c}26 \\
(2.98 \\
\%)\end{array}$ & $\begin{array}{c}9 \\
(1.03 \\
\%)\end{array}$ & $\begin{array}{c}26 \\
(2.98 \\
\%) \\
\end{array}$ & $\begin{array}{c}6 \\
(0.69 \\
\%)\end{array}$ & $\begin{array}{c}40 \\
(4.58 \\
\%) \\
\end{array}$ & $\begin{array}{c}12 \\
(1.37 \% \\
)\end{array}$ & $\begin{array}{c}26 \\
(2.98 \\
\%) \\
\end{array}$ \\
\hline $\begin{array}{l}\text { Saltwater Anglers- } \\
\text { Preferred Choice Total }\end{array}$ & \multicolumn{2}{|c|}{42} & \multicolumn{2}{|c|}{$\begin{array}{c}34 \\
(3.89 \%)\end{array}$} & \multicolumn{2}{|c|}{$\begin{array}{c}35 \\
(4.01 \%)\end{array}$} & \multicolumn{2}{|c|}{$\begin{array}{c}46 \\
(5.27 \%)\end{array}$} & \multicolumn{2}{|c|}{$\begin{array}{c}38 \\
(4.35 \%)\end{array}$} \\
\hline
\end{tabular}


Within the species model, respondents in both sample populations preferred Plan B within choice cards 21-25, with the exception of Card 25 amongst the general public respondents. With regards to this card, more respondents (2.81\%) were willing to accept a 1 day $/ 40 \%$ reduction of indoor water use restriction presumably due to higher amounts of dry land species restoration and equivalent amounts of Florida Bay species restoration. However within the saltwater anglers sample, Plan B in Card 24 exhibited a higher amount of dominance over Plan A, eliciting $4.58 \%$ of the respondents. Respondents in this sample population were willing to pay $\$ 70$ annually for the next 10 years for the high amounts of restoration amongst all the species groups and for the lowest amount of household water restrictions.

Table 4.12: Species Model Choice Card Decisions: Cards 26-30

\begin{tabular}{|c|c|c|c|c|c|c|c|c|c|c|}
\hline \multirow{2}{*}{$\begin{array}{l}\text { Choice Card } \\
\text { Identification }\end{array}$} & \multicolumn{2}{|c|}{26} & \multicolumn{2}{|c|}{27} & \multicolumn{2}{|c|}{28} & \multicolumn{2}{|c|}{29} & \multicolumn{2}{|c|}{30} \\
\hline & Plan A & $\begin{array}{l}\text { Plan } \\
\text { B }\end{array}$ & $\begin{array}{l}\text { Plan } \\
\text { A }\end{array}$ & $\begin{array}{l}\text { Plan } \\
\text { B }\end{array}$ & $\begin{array}{l}\text { Plan } \\
\text { A }\end{array}$ & $\begin{array}{l}\text { Plan } \\
\text { B }\end{array}$ & $\begin{array}{l}\text { Plan } \\
\text { A }\end{array}$ & $\begin{array}{l}\text { Plan } \\
\text { B }\end{array}$ & $\begin{array}{l}\text { Plan } \\
\text { A }\end{array}$ & $\begin{array}{l}\text { Plan } \\
\text { B }\end{array}$ \\
\hline Wetland Species & $50 \%$ & $50 \%$ & $50 \%$ & $80 \%$ & $50 \%$ & $80 \%$ & $50 \%$ & $80 \%$ & $20 \%$ & $80 \%$ \\
\hline Dry land Species & $50 \%$ & $65 \%$ & $50 \%$ & $50 \%$ & $50 \%$ & $75 \%$ & $50 \%$ & $75 \%$ & $75 \%$ & $75 \%$ \\
\hline Florida Bay Species & $60 \%$ & $75 \%$ & $75 \%$ & $75 \%$ & $75 \%$ & $75 \%$ & $75 \%$ & $90 \%$ & $90 \%$ & $90 \%$ \\
\hline Farmland Acreage & 100000 & $\begin{array}{r}1000 \\
00\end{array}$ & 0 & $\begin{array}{r}1000 \\
00\end{array}$ & 0 & $\begin{array}{r}20,00 \\
0\end{array}$ & 0 & $\begin{array}{r}1000 \\
00\end{array}$ & $\begin{array}{r}1000 \\
00\end{array}$ & $\begin{array}{r}2000 \\
00\end{array}$ \\
\hline $\begin{array}{l}\text { Restrictions on } \\
\text { Water Usage }\end{array}$ & $\begin{array}{r}2 \\
\text { days/ } \\
25 \%\end{array}$ & $\begin{array}{r}3 \\
\text { days/ } \\
10 \%\end{array}$ & $\begin{array}{r}1 \\
\text { day/ } \\
40 \%\end{array}$ & $\begin{array}{r}2 \\
\text { days/ } \\
25 \%\end{array}$ & $\begin{array}{r}1 \\
\text { day/ } \\
40 \%\end{array}$ & $\begin{array}{r}3 \\
\text { days/ } \\
10 \%\end{array}$ & $\begin{array}{r}1 \\
\text { day/ } \\
40 \%\end{array}$ & $\begin{array}{r}2 \\
\text { days/ } \\
25 \%\end{array}$ & $\begin{array}{r}2 \\
\text { days/ } \\
25 \%\end{array}$ & $\begin{array}{r}3 \\
\text { days/ } \\
10 \%\end{array}$ \\
\hline \multirow[t]{2}{*}{ Payment } & $\$ 35$ & $\$ 70$ & $\$ 0$ & $\$ 35$ & $\$ 0$ & $\$ 70$ & $\$ 0$ & $\$ 35$ & $\$ 35$ & $\$ 70$ \\
\hline & Plan A & $\begin{array}{l}\text { Plan } \\
\text { B }\end{array}$ & $\begin{array}{l}\text { Plan } \\
\text { A }\end{array}$ & $\begin{array}{l}\text { Plan } \\
\text { B }\end{array}$ & $\begin{array}{l}\text { Plan } \\
\text { A }\end{array}$ & $\begin{array}{l}\text { Plan } \\
\text { B }\end{array}$ & $\begin{array}{l}\text { Plan } \\
\text { A }\end{array}$ & $\begin{array}{l}\text { Plan } \\
\text { B }\end{array}$ & $\begin{array}{l}\text { Plan } \\
\text { A }\end{array}$ & $\begin{array}{l}\text { Plan } \\
\text { B }\end{array}$ \\
\hline $\begin{array}{l}\text { General Public- Preferred } \\
\text { Choice }\end{array}$ & $\begin{array}{c}50 \\
(2.46 \%)\end{array}$ & $\begin{array}{c}48 \\
(2.36 \\
\%)\end{array}$ & $\begin{array}{c}31 \\
(1.52 \\
\%)\end{array}$ & $\begin{array}{c}75 \\
(3.69 \\
\%)\end{array}$ & $\begin{array}{c}40 \\
(1.97 \\
\%)\end{array}$ & $\begin{array}{c}59 \\
(2.90 \\
\%)\end{array}$ & $\begin{array}{c}26 \\
(1.28 \\
\%)\end{array}$ & $\begin{array}{c}76 \\
(2.51 \\
\%)\end{array}$ & $\begin{array}{c}51 \\
(2.51 \\
\%)\end{array}$ & $\begin{array}{c}51 \\
(2.51 \\
\%)\end{array}$ \\
\hline $\begin{array}{l}\text { General Public - Preferred } \\
\text { Choice Total }\end{array}$ & \multicolumn{2}{|c|}{$\begin{array}{c}98 \\
(4.82 \%)\end{array}$} & \multicolumn{2}{|c|}{$\begin{array}{c}106 \\
(5.22 \%)\end{array}$} & \multicolumn{2}{|c|}{$\begin{array}{c}99 \\
(4.87 \%)\end{array}$} & \multicolumn{2}{|c|}{$\begin{array}{c}102 \\
(5.02 \%)\end{array}$} & \multicolumn{2}{|c|}{$\begin{array}{c}104 \\
(5.02 \%)\end{array}$} \\
\hline $\begin{array}{l}\text { Saltwater Anglers- Preferred } \\
\text { Choice }\end{array}$ & $\begin{array}{c}11 \\
(1.26 \%)\end{array}$ & $\begin{array}{c}31 \\
(3.55)\end{array}$ & $\begin{array}{c}7 \\
(0.80 \\
\%)\end{array}$ & $\begin{array}{c}39 \\
(4.47 \\
\%)\end{array}$ & $\begin{array}{c}12 \\
(1.37 \\
\%)\end{array}$ & $\begin{array}{l}29 \\
(3.32 \\
\%)\end{array}$ & $\begin{array}{c}4 \\
(0.46 \\
\%)\end{array}$ & $\begin{array}{c}42 \\
(4.81 \\
\%)\end{array}$ & $\begin{array}{c}14 \\
(1.60 \\
\%)\end{array}$ & $\begin{array}{c}33 \\
(3.78 \\
\%)\end{array}$ \\
\hline $\begin{array}{l}\text { Saltwater Anglers- Preferred } \\
\text { Choice Total }\end{array}$ & \multicolumn{2}{|c|}{$\begin{array}{c}42 \\
(4.81 \%)\end{array}$} & \multicolumn{2}{|c|}{$\begin{array}{c}46 \\
(5.27 \%)\end{array}$} & \multicolumn{2}{|c|}{$\begin{array}{c}41 \\
(4.70 \%)\end{array}$} & \multicolumn{2}{|c|}{$\begin{array}{c}46 \\
(5.27 \%)\end{array}$} & \multicolumn{2}{|c|}{$\begin{array}{c}47 \\
(5.38 \%)\end{array}$} \\
\hline
\end{tabular}


Within choice cards 26-30, Plan B again was highly preferred by respondents in the saltwater anglers sample population. However, Plan B in Cards 27 and 29 displayed a larger amount of dominance over Plan A, for which Plan B in both Card 27 and Card 29 are priced at $\$ 35$, and contain significant amounts of restoration, and a lessened restriction on water usage. With regards to the general public sample, Plan B was highly favored over Plan A in Cards 27, 28, and 30, yet not in Card 26 and Card 30. Within Card 26, respondents preferred Plan A (2.46\%) over Plan B (2.36\%), but not overwhelmingly. However, in Card 30, for the first time within either the hydrological and species model choice cards, respondents equally preferred Plan A to Plan B.

Table 4.13: Species Model Choice Card Decisions: Cards 31-35

\begin{tabular}{|c|c|c|c|c|c|c|c|c|c|c|}
\hline \multirow{2}{*}{$\begin{array}{l}\text { Choice Card } \\
\text { Identification }\end{array}$} & \multicolumn{2}{|c|}{31} & \multicolumn{2}{|c|}{32} & \multicolumn{2}{|c|}{33} & \multicolumn{2}{|c|}{34} & \multicolumn{2}{|c|}{35} \\
\hline & $\begin{array}{l}\text { Plan } \\
\text { A }\end{array}$ & $\begin{array}{l}\text { Plan } \\
\text { B } \\
\end{array}$ & $\begin{array}{l}\text { Plan } \\
\text { A }\end{array}$ & $\begin{array}{l}\text { Plan } \\
\text { B } \\
\end{array}$ & $\begin{array}{l}\text { Plan } \\
\text { A }\end{array}$ & $\begin{array}{l}\text { Plan } \\
\text { B }\end{array}$ & $\begin{array}{l}\text { Plan } \\
\text { A }\end{array}$ & $\begin{array}{l}\text { Plan } \\
\text { B } \\
\end{array}$ & $\begin{array}{l}\text { Plan } \\
\text { A }\end{array}$ & $\begin{array}{l}\text { Plan } \\
\text { B }\end{array}$ \\
\hline Wetland Species & $20 \%$ & $50 \%$ & $20 \%$ & $50 \%$ & $50 \%$ & $50 \%$ & $50 \%$ & $80 \%$ & $50 \%$ & $80 \%$ \\
\hline Dry land Species & $75 \%$ & $50 \%$ & $75 \%$ & $50 \%$ & $50 \%$ & $65 \%$ & $75 \%$ & $65 \%$ & $65 \%$ & $75 \%$ \\
\hline Florida Bay Species & $75 \%$ & $60 \%$ & $75 \%$ & $90 \%$ & $60 \%$ & $90 \%$ & $60 \%$ & $75 \%$ & $75 \%$ & $75 \%$ \\
\hline Farmland Acreage & 100000 & $\begin{array}{r}2000 \\
00 \\
\end{array}$ & 0 & $\begin{array}{r}1000 \\
00\end{array}$ & $\begin{array}{r}1000 \\
00\end{array}$ & $\begin{array}{r}2000 \\
00 \\
\end{array}$ & $\begin{array}{r}1000 \\
00\end{array}$ & $\begin{array}{r}2000 \\
00 \\
\end{array}$ & 0 & $\begin{array}{r}1000 \\
00\end{array}$ \\
\hline $\begin{array}{l}\text { Restrictions on } \\
\text { Water Usage }\end{array}$ & $\begin{array}{r}2 \\
\text { days/ } \\
25 \%\end{array}$ & $\begin{array}{r}3 \\
\text { days/ } \\
10 \%\end{array}$ & $\begin{array}{r}1 \\
\text { day/ } \\
40 \%\end{array}$ & $\begin{array}{r}2 \\
\text { days/ } \\
25 \%\end{array}$ & $\begin{array}{r}1 \\
\text { day/ } \\
40 \%\end{array}$ & $\begin{array}{r}3 \\
\text { days/ } \\
10 \% \\
\end{array}$ & $\begin{array}{r}1 \\
\text { day/ } \\
40 \%\end{array}$ & $\begin{array}{r}2 \\
\text { days/ } \\
25 \%\end{array}$ & $\begin{array}{r}1 \\
\text { day/ } \\
40 \%\end{array}$ & $\begin{array}{r}2 \\
\text { days/ } \\
25 \%\end{array}$ \\
\hline \multirow[t]{2}{*}{ Payment } & $\$ 35$ & $\$ 70$ & $\$ 0$ & $\$ 35$ & $\$ 0$ & $\$ 70$ & $\$ 35$ & $\$ 70$ & $\$ 0$ & $\$ 35$ \\
\hline & Plan A & $\begin{array}{l}\text { Plan } \\
\text { B }\end{array}$ & $\begin{array}{l}\text { Plan } \\
\text { A }\end{array}$ & $\begin{array}{l}\text { Plan } \\
\text { B }\end{array}$ & $\begin{array}{l}\text { Plan } \\
\text { A }\end{array}$ & $\begin{array}{l}\text { Plan } \\
\text { B }\end{array}$ & $\begin{array}{l}\text { Plan } \\
\text { A }\end{array}$ & $\begin{array}{l}\text { Plan } \\
\text { B }\end{array}$ & $\begin{array}{l}\text { Plan } \\
\text { A }\end{array}$ & $\begin{array}{l}\text { Plan } \\
\text { B }\end{array}$ \\
\hline $\begin{array}{l}\text { General Public- Preferred } \\
\text { Choice }\end{array}$ & $\begin{array}{c}62 \\
(3.05 \%)\end{array}$ & $\begin{array}{c}41 \\
(2.02 \\
\%)\end{array}$ & $\begin{array}{c}39 \\
(1.91 \\
\%)\end{array}$ & $\begin{array}{c}69 \\
(3.40 \\
\%) \\
\end{array}$ & $\begin{array}{c}42 \\
(2.07 \\
\%)\end{array}$ & $\begin{array}{c}60 \\
(2.95 \\
\%) \\
\end{array}$ & $\begin{array}{c}50 \\
(2.46 \\
\%)\end{array}$ & $\begin{array}{c}56 \\
(2.76 \\
\%) \\
\end{array}$ & $\begin{array}{c}33 \\
(1.62 \\
\%)\end{array}$ & $\begin{array}{c}70 \\
(3.44 \\
\%)\end{array}$ \\
\hline $\begin{array}{l}\text { General Public - Preferred } \\
\text { Choice Total }\end{array}$ & \multicolumn{2}{|c|}{$\begin{array}{c}103 \\
(5.07 \%)\end{array}$} & \multicolumn{2}{|c|}{$\begin{array}{c}108 \\
(5.31 \%)\end{array}$} & \multicolumn{2}{|c|}{$\begin{array}{c}102 \\
(5.31 \%)\end{array}$} & \multicolumn{2}{|c|}{$\begin{array}{c}105 \\
(5.22 \%)\end{array}$} & \multicolumn{2}{|c|}{$\begin{array}{c}103 \\
(5.07 \%)\end{array}$} \\
\hline $\begin{array}{l}\text { Saltwater Anglers- Preferred } \\
\text { Choice }\end{array}$ & $\begin{array}{c}17 \\
(1.95 \%)\end{array}$ & $\begin{array}{c}28 \\
(3.21 \\
\%)\end{array}$ & $\begin{array}{c}11 \\
(1.26 \\
\%)\end{array}$ & $\begin{array}{c}37 \\
(4.24 \\
\%)\end{array}$ & $\begin{array}{l}13 \\
(1.49 \\
\%)\end{array}$ & $\begin{array}{c}37 \\
(4.24 \\
\%)\end{array}$ & $\begin{array}{c}13 \\
(1.49 \\
\%)\end{array}$ & $\begin{array}{c}27 \\
(3.09 \\
\%)\end{array}$ & $\begin{array}{c}8 \\
(0.92 \\
\%)\end{array}$ & $\begin{array}{c}39 \\
(4.47 \\
\%)\end{array}$ \\
\hline $\begin{array}{l}\text { Saltwater Anglers- Preferred } \\
\text { Choice Total }\end{array}$ & \multicolumn{2}{|c|}{$\begin{array}{c}45 \\
(5.15 \%)\end{array}$} & \multicolumn{2}{|c|}{$\begin{array}{c}48 \\
(5.50 \%)\end{array}$} & \multicolumn{2}{|c|}{$\begin{array}{c}50 \\
(5.73 \%)\end{array}$} & \multicolumn{2}{|c|}{$\begin{array}{c}40 \\
(4.58 \%)\end{array}$} & \multicolumn{2}{|c|}{$\begin{array}{c}47 \\
(5.38 \%)\end{array}$} \\
\hline
\end{tabular}




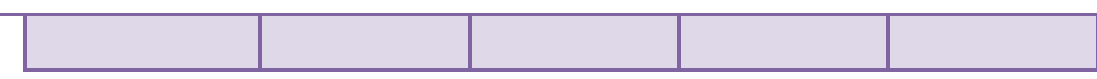

For Cards 31-35, once again, Plan B was preferred across the choice cards within the saltwater anglers sample population. With regards to Card 35, however, Plan B was more dominant than Plan A, with $4.5 \%$ of respondents choosing Plan B in the saltwater anglers sample. As in the previous table, this outcome was precipitated by the $\$ 35$ payment price on Plan B, which in this case contained high levels of restoration. Within the general public sample population, respondents preferred Plan A in Card 31 over Plan B, likely due to the higher amounts of restoration for dry land and Florida Bay species population within Plan A, and despite the lower amounts of water restrictions contained within Plan B.

Table 4.14: Species Model Choice Card Decisions: Cards 36-40

\begin{tabular}{|c|c|c|c|c|c|c|c|c|c|c|}
\hline \multirow{2}{*}{$\begin{array}{l}\text { Choice Card } \\
\text { Identification }\end{array}$} & \multicolumn{2}{|c|}{36} & \multicolumn{2}{|c|}{37} & \multicolumn{2}{|c|}{38} & \multicolumn{2}{|c|}{39} & \multicolumn{2}{|c|}{40} \\
\hline & Plan A & $\begin{array}{l}\text { Plan } \\
\text { B }\end{array}$ & $\begin{array}{l}\text { Plan } \\
\text { A }\end{array}$ & $\begin{array}{l}\text { Plan } \\
\text { B }\end{array}$ & $\begin{array}{l}\text { Plan } \\
\text { A }\end{array}$ & $\begin{array}{l}\text { Plan } \\
\text { B }\end{array}$ & $\begin{array}{l}\text { Plan } \\
\text { A }\end{array}$ & $\begin{array}{l}\text { Plan } \\
\text { B }\end{array}$ & $\begin{array}{l}\text { Plan } \\
\text { A }\end{array}$ & $\begin{array}{l}\text { Plan } \\
\text { B }\end{array}$ \\
\hline Wetland Species & $50 \%$ & $50 \%$ & $50 \%$ & $80 \%$ & $80 \%$ & $80 \%$ & $50 \%$ & $80 \%$ & $20 \%$ & $50 \%$ \\
\hline Dry land Species & $65 \%$ & $75 \%$ & $50 \%$ & $65 \%$ & $50 \%$ & $65 \%$ & $75 \%$ & $75 \%$ & $65 \%$ & $50 \%$ \\
\hline Florida Bay Species & $75 \%$ & $90 \%$ & $90 \%$ & $60 \%$ & $60 \%$ & $75 \%$ & $60 \%$ & $75 \%$ & $60 \%$ & $90 \%$ \\
\hline Farmland Acreage & 100000 & $\begin{array}{r}2000 \\
00\end{array}$ & $\begin{array}{r}1000 \\
00\end{array}$ & $\begin{array}{r}2000 \\
00\end{array}$ & $\begin{array}{r}1000 \\
00\end{array}$ & $\begin{array}{r}20000 \\
0\end{array}$ & $\begin{array}{r}1000 \\
00\end{array}$ & $\begin{array}{r}2000 \\
00\end{array}$ & 0 & $\begin{array}{r}1000 \\
00\end{array}$ \\
\hline $\begin{array}{l}\text { Restrictions on } \\
\text { Water Usage }\end{array}$ & $\begin{array}{r}2 \\
\text { days/ } \\
25 \%\end{array}$ & $\begin{array}{r}3 \\
\text { days/ } \\
10 \%\end{array}$ & $\begin{array}{r}2 \\
\text { days/ } \\
25 \%\end{array}$ & $\begin{array}{r}3 \\
\text { days/ } \\
10 \%\end{array}$ & $\begin{array}{r}2 \\
\text { days/ } \\
25 \%\end{array}$ & $\begin{array}{r}3 \\
\text { days/ } \\
10 \%\end{array}$ & $\begin{array}{r}2 \\
\text { days/ } \\
25 \%\end{array}$ & $\begin{array}{r}3 \\
\text { days/ } \\
10 \%\end{array}$ & $\begin{array}{r}1 \\
\text { day/ } \\
40 \%\end{array}$ & $\begin{array}{r}2 \\
\text { days/ } \\
25 \%\end{array}$ \\
\hline \multirow[t]{2}{*}{ Payment } & $\$ 35$ & $\$ 70$ & $\$ 35$ & $\$ 70$ & $\$ 35$ & $\$ 70$ & $\$ 35$ & $\$ 70$ & $\$ 0$ & $\$ 35$ \\
\hline & Plan A & $\begin{array}{l}\text { Plan } \\
\text { B }\end{array}$ & $\begin{array}{l}\text { Plan } \\
\text { A }\end{array}$ & $\begin{array}{l}\text { Plan } \\
\text { B }\end{array}$ & $\begin{array}{l}\text { Plan } \\
\text { A }\end{array}$ & $\begin{array}{l}\text { Plan } \\
\text { B }\end{array}$ & $\begin{array}{l}\text { Plan } \\
\text { A }\end{array}$ & $\begin{array}{l}\text { Plan } \\
\text { B }\end{array}$ & $\begin{array}{l}\text { Plan } \\
\text { A }\end{array}$ & $\begin{array}{l}\text { Plan } \\
\text { B }\end{array}$ \\
\hline $\begin{array}{l}\text { General Public- Preferred } \\
\text { Choice }\end{array}$ & $\begin{array}{c}45 \\
(2.21 \%)\end{array}$ & $\begin{array}{c}57 \\
(2.81 \\
\%)\end{array}$ & $\begin{array}{c}60 \\
(2.95 \\
\%) \\
\end{array}$ & $\begin{array}{c}36 \\
(1.77 \\
\%)\end{array}$ & $\begin{array}{c}53 \\
(2.61 \\
\%) \\
\end{array}$ & $\begin{array}{c}47 \\
(2.31 \\
\%) \\
\end{array}$ & $\begin{array}{c}54 \\
(2.66 \\
\%)\end{array}$ & $\begin{array}{c}45 \\
(2.21 \\
\%)\end{array}$ & $\begin{array}{c}31 \\
(1.53 \\
\%)\end{array}$ & $\begin{array}{c}73 \\
(3.59 \\
\%) \\
\end{array}$ \\
\hline $\begin{array}{l}\text { General Public - Preferred } \\
\text { Choice Total }\end{array}$ & \multicolumn{2}{|c|}{$\begin{array}{c}102 \\
(5.02 \%)\end{array}$} & \multicolumn{2}{|c|}{$\begin{array}{c}96 \\
(4.72 \%)\end{array}$} & \multicolumn{2}{|c|}{$\begin{array}{c}100 \\
(4.92 \%)\end{array}$} & \multicolumn{2}{|c|}{$\begin{array}{c}99 \\
(4.87 \%)\end{array}$} & \multicolumn{2}{|c|}{$\begin{array}{c}104 \\
(5.12 \%)\end{array}$} \\
\hline $\begin{array}{l}\text { Saltwater Anglers- Preferred } \\
\text { Choice }\end{array}$ & $\begin{array}{c}16 \\
(1.83 \%)\end{array}$ & $\begin{array}{c}30 \\
(3.44 \\
\%)\end{array}$ & $\begin{array}{c}24 \\
(2.75 \\
\%)\end{array}$ & $\begin{array}{c}22 \\
(2.52 \\
\%)\end{array}$ & $\begin{array}{c}11 \\
(1.26 \\
\%)\end{array}$ & $\begin{array}{c}34 \\
(3.89 \\
\%) \\
\end{array}$ & $\begin{array}{c}12 \\
(1.37 \\
\%)\end{array}$ & $\begin{array}{c}33 \\
(3.78 \\
\%) \\
\end{array}$ & $\begin{array}{c}9 \\
(1.03 \\
\%)\end{array}$ & $\begin{array}{c}35 \\
(4.01 \\
\%)\end{array}$ \\
\hline
\end{tabular}




\begin{tabular}{|c|c|c|c|c|c|}
\hline $\begin{array}{l}\text { Saltwater Anglers- Preferred } \\
\text { Choice Total }\end{array}$ & $\begin{array}{c}46 \\
(5.27 \%)\end{array}$ & $\begin{array}{c}46 \\
(5.27 \%)\end{array}$ & $\begin{array}{c}45 \\
(5.15 \%)\end{array}$ & $\begin{array}{c}45 \\
(5.15 \%)\end{array}$ & $\begin{array}{c}44 \\
(5.04 \%)\end{array}$ \\
\hline Subtotal & \multicolumn{3}{|c|}{$\begin{array}{c}\text { General Public } \\
\text { Plan A: } 871(42.86 \%) \\
\text { Plan B: } 1161(57.14 \%) \\
n=2,032\end{array}$} & \multicolumn{2}{|c|}{$\begin{array}{c}(5.15 \%) \quad(5.04 \%) \\
\text { Saltwater Anglers } \\
\text { Plan A: } 235(26.92 \%) \\
\text { Plan B: } 638(73.08 \%) \\
n=873\end{array}$} \\
\hline
\end{tabular}

Within the general public sample population, respondents preferred Plan A over Plan B within Cards 37, 38, and 39, and vice versa within Cards 36 and Card 40. This outcome was likely due to the low marginal differences between levels of species restoration within Cards 37, 38, and 39.

Within Cards 36-40, Plan B was the favored restoration plan for cards 36, 38, 19, and 40, but not card 37 amongst respondents in the saltwater angler sample. By a very small margin, respondents in this sample population preferred Plan A over Plan B. Although Plan B did contain higher amounts of species restoration for both the wetland and dry land species population, and a lesser restriction on household water usage, Plan A contained significantly more restoration for the potentially lucrative Florida Bay species. Overall, Plan B was the most highly favored plan within both sample populations across all 20 species model choice cards with $57.1 \%$ in the general public and even higher $73.1 \%$ in the saltwater anglers population.

4.4.2.1 Trends within the Hydrological and Species Model Milon et al. (1999) adapted Choice Cards

After an in-depth analysis of the individual choice cards, several trends emerged across both sample populations and across the hydrological and species model choice cards. Overall, Plan B was the most favored plan within both the hydrological and species model and across the general public and saltwater anglers sample population. However, 
the favorability for Plan B over Plan A was not as pronounced within the general public sample as in the saltwater anglers sample. The overall favorability for Plan B within the general public garnered support within the mid-50s percentage for both models, while this number was in the low 70s percentage in the saltwater anglers sample. Furthermore, the higher favorability for Plan B does not necessarily indicate that respondents in both sample populations were willing to pay the highest amount for restoration $(\$ 70)$, it does indicate that the respondents were generally willing to pay for restoration, and more often than not rejected restoration plans priced at $\$ 0$. Also, generally speaking, "restrictions on water usage" was a significant choice factor. The level "1 day a week of outdoor use; $40 \%$ restrictions for indoor use" garnered very low support, often in the single digits between both models and both sample populations. Within the species model, restoration options that were priced at $\$ 35$ and included medium to high levels of species restoration were dominantly popular over the complementary paired $\$ 0$ plans within both sample populations. Overwhelmingly when respondents were presented with a plan of this nature (medium to high restoration priced at \$35), they chose this plan, suggesting that respondents are willing to pay for restoration at moderate prices.

\subsubsection{Decisions by Individual Choice Cards for the Newly Created Choice Cards} The following tables depict the tradeoff and management plan scenarios for each of the choice cards. As previously mentioned, in order to increase the number of tradeoff scenarios represented between the ecological and social attributes, the attribute combinations changed within each of the choice cards. As a result of the non-stabilization of the attributes within this set of choice cards, I could not detect any patterns amongst 
these cards, as I did with the previous sets. However, Tables 4.15-4.34 represents the respondent decision and preference for management plans per each choice card.

\section{Table 4.15: Choice Card 41 Decision}

\begin{tabular}{|c|c|c|c|}
\hline \multirow{2}{*}{$\begin{array}{l}\text { Choice Card } \\
\text { Identification }\end{array}$} & \multicolumn{3}{|c|}{41} \\
\hline & Take No Action & Plan A & Plan B \\
\hline Agricultural Water Demands & $20 \%$ demands not met & $\begin{array}{c}10 \% \text { demands not } \\
\text { met }\end{array}$ & No unmet demands \\
\hline Municipal Water Demands & $10 \%$ decrease & $10 \%$ increase & No unmet demands \\
\hline Water Levels in Lake Okeechobee & $\begin{array}{l}\text { No change in fish } \\
\text { abundance }\end{array}$ & $20 \%$ decrease & $60 \%$ decrease \\
\hline Water Levels in Estuaries & PW 1/2 years & $1 / 10$ years & $1 / 30$ years \\
\hline \multirow[t]{2}{*}{ Payment } & $\$ 0$ & $\$ 35$ & $\$ 70$ \\
\hline & Take No Action & Plan A & Plan B \\
\hline General Public Preferred Choice & $5(0.52 \%)$ & $45(4.64 \%)$ & $49(5.05 \%)$ \\
\hline General Public Total & \multicolumn{3}{|c|}{$99(10.21 \%)$} \\
\hline $\begin{array}{l}\text { Saltwater Anglers Preferred } \\
\text { Choice }\end{array}$ & $7(0.80 \%)$ & $33(3.78 \%)$ & $34(3.89 \%)$ \\
\hline Saltwater Anglers- Total & \multicolumn{3}{|c|}{$74(8.48 \%)$} \\
\hline
\end{tabular}

Table 4.16: Choice Card 42 Decision

\begin{tabular}{|c|c|c|c|}
\hline \multirow[t]{2}{*}{ Choice Card Identification } & \multicolumn{3}{|c|}{42} \\
\hline & Take No Action & Plan A & Plan B \\
\hline Agricultural Water Demands & $20 \%$ demands not met & $\begin{array}{l}10 \% \text { of demands not } \\
\text { met }\end{array}$ & No unmet demands \\
\hline Municipal Water Demands & $15 \%$ decrease & $10 \%$ decrease & No unmet demands \\
\hline $\begin{array}{l}\text { Recreation in Everglades National } \\
\text { Park }\end{array}$ & $\begin{array}{l}20 \% \text { decrease in } \\
\text { access }\end{array}$ & $20 \%$ increase in access & $\begin{array}{l}30 \% \text { increase in } \\
\text { access }\end{array}$ \\
\hline Recreation in Florida Bay & $\begin{array}{c}20 \% \text { decrease in } \\
\text { access }\end{array}$ & $10 \%$ increase in access & $\begin{array}{c}30 \% \text { increase in } \\
\text { access }\end{array}$ \\
\hline \multirow[t]{2}{*}{ Payment } & $\$ 0$ & $\$ 35$ & $\$ 70$ \\
\hline & Take No Action & Plan A & Plan B \\
\hline General Public Preferred Choice & $3(0.31 \%)$ & $60(6.19 \%)$ & $40(4.12 \%)$ \\
\hline General Public Total & \multicolumn{3}{|c|}{$103(10.62 \%)$} \\
\hline Saltwater Anglers Preferred Choice & $3(0.34 \%)$ & $55(6.30 \%)$ & $31(3.55 \%)$ \\
\hline Saltwater Anglers- Total & \multicolumn{3}{|c|}{$89(10.19 \%)$} \\
\hline
\end{tabular}


Table 4.17: Choice Card 43 Decision

\begin{tabular}{|c|c|c|c|}
\hline \multirow[t]{2}{*}{ Choice Card Identification } & \multicolumn{3}{|c|}{43} \\
\hline & Take No Action & Plan A & Plan B \\
\hline Agricultural Water Demands & $30 \%$ demands not met & $5 \%$ demands not met & No unmet demands \\
\hline Municipal Water Demands & $10 \%$ decrease & $5 \%$ increase & No unmet demands \\
\hline $\begin{array}{l}\text { Recreation in Everglades National } \\
\text { Park }\end{array}$ & $\begin{array}{c}10 \% \text { decrease in } \\
\text { access }\end{array}$ & $\begin{array}{c}20 \% \text { increase in } \\
\text { access }\end{array}$ & $30 \%$ increase in access \\
\hline Inland Mangrove Expansion & $20 \%$ increase & $10 \%$ increase & $5 \%$ decrease \\
\hline \multirow[t]{2}{*}{ Payment } & $\$ 0$ & $\$ 25$ & $\$ 50$ \\
\hline & Take No Action & Plan A & Plan B \\
\hline General Public Preferred Choice & $8(0.82 \%)$ & $39(4.02 \%)$ & $53(5.46 \%)$ \\
\hline General Public Total & \multicolumn{3}{|c|}{$100(10.31 \%)$} \\
\hline Saltwater Anglers Preferred Choice & $6(0.69 \%)$ & $36(4.12 \%)$ & $51(5.84 \%)$ \\
\hline Saltwater Anglers- Total & \multicolumn{3}{|c|}{$93(10.65 \%)$} \\
\hline
\end{tabular}

Table 4.18: Choice Card 44 Decision

\begin{tabular}{|c|c|c|c|}
\hline \multirow{2}{*}{$\begin{array}{l}\text { Choice Card } \\
\text { Identification }\end{array}$} & \multicolumn{3}{|c|}{44} \\
\hline & Take No Action & Plan A & Plan B \\
\hline Agricultural Water Demands & $30 \%$ demands not met & $\begin{array}{l}10 \% \text { demands not } \\
\text { met }\end{array}$ & No unmet demands \\
\hline Municipal Water Demands & $15 \%$ decrease & $10 \%$ increase & No unmet demands \\
\hline Recreation in Florida Bay & $\begin{array}{c}10 \% \text { decrease in } \\
\text { access }\end{array}$ & $\begin{array}{l}10 \% \text { increase in } \\
\text { access }\end{array}$ & $20 \%$ increase in access \\
\hline Inland Mangrove Expansion & $30 \%$ increase & $10 \%$ increase & $10 \%$ decrease \\
\hline \multirow[t]{2}{*}{ Payment } & $\$ 0$ & $\$ 35$ & $\$ 50$ \\
\hline & Take No Action & Plan A & Plan B \\
\hline General Public Preferred Choice & $7(0.72 \%)$ & $46(4.74 \%)$ & $43(4.43 \%)$ \\
\hline General Public Total & \multicolumn{3}{|c|}{$96(9.90 \%)$} \\
\hline $\begin{array}{l}\text { Saltwater Anglers Preferred } \\
\text { Choice }\end{array}$ & $7(0.80 \%)$ & $48(5.50 \%)$ & $35(4.01 \%)$ \\
\hline Saltwater Anglers- Total & \multicolumn{3}{|c|}{$90(10.31 \%)$} \\
\hline
\end{tabular}

Table 4.19: Choice Card 45 Decision

\begin{tabular}{|c|c|c|c|}
\hline \multirow{2}{*}{$\begin{array}{l}\text { Choice Card } \\
\text { Identification }\end{array}$} & \multicolumn{3}{|c|}{45} \\
\hline & Take No Action & Plan A & Plan B \\
\hline Agricultural Water Demands & $\begin{array}{l}30 \% \text { demands not } \\
\text { met }\end{array}$ & $\begin{array}{l}5 \% \text { demands not } \\
\text { met }\end{array}$ & No unmet demands \\
\hline Restriction on Urban Expansion & Current Rate & Low Rate & No Further \\
\hline
\end{tabular}




\begin{tabular}{l|c|c|c|}
\hline Water Levels in Lake Okeechobee & No change & $\begin{array}{c}20 \% \text { decrease in } \\
\text { fish }\end{array}$ & $60 \%$ decrease in fish \\
\hline Water Levels in Estuaries & PW 1/2 years & $1 / 10$ years & $1 / 20$ years \\
\hline Payment & $\$ 0$ & $\$ 35$ & $\$ 70$ \\
\hline & Take No Action & Plan A & Plan B \\
\hline General Public Preferred Choice & $8(0.82 \%)$ & $46(4.47 \%)$ & $45(4.64 \%)$ \\
\hline General Public Total & & $\mathbf{9 9 ( 1 0 . 2 1 \% )}$ & $50(5.73 \%)$ \\
\hline $\begin{array}{l}\text { Saltwater Anglers Preferred } \\
\text { Choice }\end{array}$ & $4(0.46 \%)$ & $42(4.81 \%)$ & \\
\hline $\begin{array}{l}\text { Saltwater Anglers- Total } \\
\text { nat }\end{array}$ & & $\mathbf{9 6 ~ ( 1 1 . 0 0 \% )}$ \\
\hline
\end{tabular}

Table 4.20: Choice Card 46 Decision

\begin{tabular}{|c|c|c|c|}
\hline \multirow[t]{2}{*}{ Choice Card Identification } & \multicolumn{3}{|c|}{46} \\
\hline & Take No Action & Plan A & Plan B \\
\hline Agricultural Water Demands & $20 \%$ demands not met & $\begin{array}{l}10 \% \text { demands not } \\
\text { met }\end{array}$ & No unmet demands \\
\hline Restriction on Urban Expansion & Current Rate & Low Rate & No Further \\
\hline $\begin{array}{l}\text { Recreation in Everglades National } \\
\text { Park }\end{array}$ & $\begin{array}{l}10 \% \text { decrease in } \\
\text { access }\end{array}$ & $\begin{array}{l}10 \% \text { increase in } \\
\text { access }\end{array}$ & $40 \%$ increase in access \\
\hline Recreation in Florida Bay & $\begin{array}{l}10 \% \text { decrease in } \\
\text { access }\end{array}$ & $5 \%$ increase in access & $30 \%$ increase in access \\
\hline \multirow[t]{2}{*}{ Payment } & $\$ 0$ & $\$ 25$ & $\$ 70$ \\
\hline & Take No Action & Plan A & Plan B \\
\hline General Public Preferred Choice & $6(0.62 \%)$ & $60(6.19 \%)$ & $37(3.81 \%)$ \\
\hline General Public Total & \multicolumn{3}{|c|}{$103(10.62 \%)$} \\
\hline Saltwater Anglers Preferred Choice & $2(0.23 \%)$ & $63(7.22 \%)$ & $27(3.09 \%)$ \\
\hline Saltwater Anglers Total & \multicolumn{3}{|c|}{$92(10.54 \%)$} \\
\hline
\end{tabular}

Table 4.21: Choice Card 47 Decision

\begin{tabular}{|c|c|c|c|}
\hline \multirow[t]{2}{*}{ Choice Card Identification } & \multicolumn{3}{|c|}{47} \\
\hline & Take No Action & Plan A & Plan B \\
\hline Agricultural Water Demands & $20 \%$ demands not met & $5 \%$ demands not met & No unmet demands \\
\hline Restriction on Urban Expansion & Current Rate & Low Rate & No Further \\
\hline $\begin{array}{l}\text { Recreation in Everglades National } \\
\text { Park }\end{array}$ & $\begin{array}{l}20 \% \text { decrease in } \\
\text { access }\end{array}$ & $\begin{array}{c}10 \% \text { increase in } \\
\text { access }\end{array}$ & $40 \%$ increase in access \\
\hline Inland Mangrove Expansion & $20 \%$ increase & $10 \%$ increase & $10 \%$ decrease \\
\hline \multirow[t]{2}{*}{ Payment } & $\$ 0$ & $\$ 25$ & $\$ 70$ \\
\hline & Take No Action & Plan A & Plan B \\
\hline General Public Preferred Choice & $3(0.31 \%)$ & $34(3.51 \%)$ & $59(6.08 \%)$ \\
\hline General Public Total & \multicolumn{3}{|c|}{$96(9.90 \%)$} \\
\hline Saltwater Anglers Preferred Choice & $5(0.57 \%)$ & $50(5.73 \%)$ & $35(4.01 \%)$ \\
\hline
\end{tabular}


Table 4.22: Choice Card 48 Decision

\begin{tabular}{|c|c|c|c|}
\hline \multirow{2}{*}{$\begin{array}{l}\text { Choice Card } \\
\text { Identification }\end{array}$} & \multicolumn{3}{|c|}{48} \\
\hline & Take No Action & Plan A & Plan B \\
\hline Agricultural Water Demands & $30 \%$ demands not met & $\begin{array}{l}10 \% \text { demands not } \\
\text { met }\end{array}$ & No unmet demands \\
\hline Restriction on Urban Expansion & Current Rate & Low Rate & No Further \\
\hline Recreation in Florida Bay & $\begin{array}{l}20 \% \text { decrease in } \\
\text { access }\end{array}$ & $\begin{array}{l}5 \% \text { increase in } \\
\text { access }\end{array}$ & $20 \%$ increase in access \\
\hline Inland Mangrove Expansion & $30 \%$ increase & $5 \%$ increase & $5 \%$ decrease \\
\hline \multirow[t]{2}{*}{ Payment } & $\$ 0$ & $\$ 25$ & $\$ 50$ \\
\hline & Take No Action & Plan A & Plan B \\
\hline General Public Preferred Choice & $10(1.03 \%)$ & $38(3.92 \%)$ & $41(4.23 \%)$ \\
\hline General Public Total & \multicolumn{3}{|c|}{$89(9.18 \%)$} \\
\hline $\begin{array}{l}\text { Saltwater Anglers Preferred } \\
\text { Choice }\end{array}$ & $7(0.80 \%)$ & $48(5.50 \%)$ & $34(3.89 \%)$ \\
\hline Saltwater Anglers Total & \multicolumn{3}{|c|}{$89(10.19 \%)$} \\
\hline
\end{tabular}

Table 4.23: Choice Card 49 Decision

\begin{tabular}{|c|c|c|c|}
\hline \multirow{2}{*}{$\begin{array}{c}\text { Choice Card } \\
\text { Identification }\end{array}$} & \multicolumn{3}{|c|}{49} \\
\hline & Take No Action & Plan A & Plan B \\
\hline Municipal Water Demands & $10 \%$ decrease & $10 \%$ increase & No unmet demands \\
\hline Urban Flood Risk & Flooding $1 / 20$ years & $\begin{array}{l}\text { Flooding } 1 / 7 \\
\text { years }\end{array}$ & Flooding $1 / 5$ years \\
\hline Water Levels in Lake Okeechobee & $\begin{array}{l}\text { No change in fish } \\
\text { abundance }\end{array}$ & $20 \%$ decrease & $80 \%$ decrease \\
\hline Water Levels in Estuaries & PW every years & PW 1/ 10 years & PW 1/ 30 years \\
\hline \multirow[t]{2}{*}{ Payment } & $\$ 0$ & $\$ 35$ & $\$ 70$ \\
\hline & Take No Action & Plan A & Plan B \\
\hline General Public Preferred Choice & $6(0.62 \%)$ & $28(2.89 \%)$ & $59(6.08 \%)$ \\
\hline General Public Total & \multicolumn{3}{|c|}{$93(9.59 \%)$} \\
\hline $\begin{array}{l}\text { Saltwater Anglers Preferred } \\
\text { Choice }\end{array}$ & $10(1.15 \%)$ & $31(3.55 \%)$ & $34(3.89 \%)$ \\
\hline Saltwater Anglers Total & \multicolumn{3}{|c|}{$75(8.59 \%)$} \\
\hline
\end{tabular}


Table 4.24: Choice Card 50 Decision

\begin{tabular}{|c|c|c|c|c|}
\hline \multirow[t]{2}{*}{ Choice Card Identification } & \multicolumn{4}{|c|}{50} \\
\hline & Take No Action & \multicolumn{2}{|c|}{ Plan A } & Plan B \\
\hline Municipal Water Demands & $10 \%$ decrease & \multicolumn{2}{|c|}{$5 \%$ increase } & No unmet demands \\
\hline Urban Flood Risk & Flooding $1 / 20$ years & \multicolumn{2}{|c|}{ Flooding $1 / 7$ years } & Flooding 1 / 2 years \\
\hline $\begin{array}{l}\text { Recreation in Everglades National } \\
\text { Park }\end{array}$ & $\begin{array}{l}20 \% \text { decrease in } \\
\text { access }\end{array}$ & \multicolumn{2}{|c|}{$\begin{array}{l}10 \% \text { increase in } \\
\text { access }\end{array}$} & $\begin{array}{l}30 \% \text { increase in } \\
\text { access }\end{array}$ \\
\hline Recreation in Florida Bay & $\begin{array}{c}20 \% \text { decrease in } \\
\text { access }\end{array}$ & \multicolumn{2}{|c|}{$5 \%$ increase in access } & $\begin{array}{c}20 \% \text { increase in } \\
\text { access }\end{array}$ \\
\hline \multirow[t]{2}{*}{ Payment } & $\$ 0$ & \multicolumn{2}{|c|}{$\$ 25$} & $\$ 50$ \\
\hline & Take No Action & \multicolumn{2}{|c|}{ Plan A } & Plan B \\
\hline General Public Preferred Choice & $11(1.13 \%)$ & \multicolumn{2}{|c|}{$36(3.71 \%)$} & $45(4.64 \%)$ \\
\hline General Public Total & \multicolumn{4}{|c|}{$92(9.48 \%)$} \\
\hline Saltwater Anglers Preferred Choice & $11(1.26 \%)$ & \multicolumn{2}{|c|}{$47(5.38 \%)$} & $27(3.09 \%)$ \\
\hline Saltwater Anglers Total & \multicolumn{4}{|c|}{$85(9.74 \%)$} \\
\hline Subtotal & \multicolumn{2}{|c|}{$\begin{array}{c}\text { General Public } \\
\text { Take No Action: } 67(6.91 \%) \\
\text { Plan A: } 432(44.54 \%) \\
\text { Plan B: } 471(48.56 \%) \\
\text { n = 970 }\end{array}$} & \multicolumn{2}{|c|}{$\begin{array}{c}\text { Saltwater Anglers } \\
\text { Take No Action: } 62(7.10 \%) \\
\text { Plan A: } 453(51.89 \%) \\
\text { Plan B: } 358(41.01 \%) \\
\text { n }=873\end{array}$} \\
\hline
\end{tabular}

Table 4.25: Choice Card 51 Decision

\begin{tabular}{|c|c|c|c|}
\hline \multirow[t]{2}{*}{ Choice Card Identification } & \multicolumn{3}{|c|}{51} \\
\hline & Take No Action & Plan A & Plan B \\
\hline Municipal Water Demands & $15 \%$ decrease & $10 \%$ increase & No unmet demands \\
\hline Urban Flood Risk & Flooding $1 / 20$ years & Flooding $1 / 10$ years & Flooding $1 / 5$ years \\
\hline $\begin{array}{l}\text { Recreation in Everglades National } \\
\text { Park }\end{array}$ & $\begin{array}{l}10 \% \text { decrease in } \\
\text { access }\end{array}$ & $\begin{array}{l}10 \% \text { increase in } \\
\text { access }\end{array}$ & $\begin{array}{l}40 \% \text { increase in } \\
\text { access }\end{array}$ \\
\hline Inland Mangrove Expansion & $30 \%$ increase & $10 \%$ increase & $10 \%$ decrease \\
\hline \multirow[t]{2}{*}{ Payment } & $\$ 0$ & $\$ 35$ & $\$ 70$ \\
\hline & Take No Action & Plan A & Plan B \\
\hline General Public Preferred Choice & $11(1.13 \%)$ & $29(2.99 \%)$ & $59(6.08 \%)$ \\
\hline General Public Total & \multicolumn{3}{|c|}{$99(10.21 \%)$} \\
\hline Saltwater Anglers Preferred Choice & $7(0.80 \%)$ & $39(4.47 \%)$ & $28(3.21 \%)$ \\
\hline Saltwater Anglers Total & \multicolumn{3}{|c|}{$74(8.48 \%)$} \\
\hline
\end{tabular}


Table 4.26: Choice Card 52 Decision

\begin{tabular}{|c|c|c|c|}
\hline \multirow{2}{*}{$\begin{array}{l}\text { Choice Card } \\
\text { Identification }\end{array}$} & \multicolumn{3}{|c|}{52} \\
\hline & Take No Action & Plan A & Plan B \\
\hline Municipal Water Demands & $10 \%$ decrease & $5 \%$ increase & No unmet demands \\
\hline Urban Flood Risk & Flooding $1 / 15$ years & Flooding $1 / 10$ years & Flooding $1 / 5$ years \\
\hline Recreation in Florida Bay & $\begin{array}{l}20 \% \text { decrease in } \\
\text { access }\end{array}$ & $\begin{array}{c}10 \% \text { increase in } \\
\text { access }\end{array}$ & $30 \%$ increase in access \\
\hline Inland Mangrove Expansion & $20 \%$ increase & $10 \%$ increase & $5 \%$ decrease \\
\hline \multirow[t]{2}{*}{ Payment } & $\$ 0$ & $\$ 25$ & $\$ 70$ \\
\hline & Take No Action & Plan A & Plan B \\
\hline General Public Preferred Choice & $12(1.24 \%)$ & $36(3.71 \%)$ & $55(5.67 \%)$ \\
\hline General Public Total & \multicolumn{3}{|c|}{$103(10.62 \%)$} \\
\hline $\begin{array}{l}\text { Saltwater Anglers Preferred } \\
\text { Choice }\end{array}$ & $6(0.69 \%)$ & $44(5.04 \%)$ & $42(4.81 \%)$ \\
\hline Saltwater Anglers Total & \multicolumn{3}{|c|}{$92(10.54 \%)$} \\
\hline
\end{tabular}

Table 4.27: Choice Card 53 Decision

\begin{tabular}{|c|c|c|c|}
\hline \multirow{2}{*}{$\begin{array}{l}\text { Choice Card } \\
\text { Identification }\end{array}$} & \multicolumn{3}{|c|}{53} \\
\hline & Take No Action & Plan A & Plan B \\
\hline Municipal Water Demands & $10 \%$ decrease & $5 \%$ increase & No unmet demands \\
\hline Restrictions on Urban Expansion & Current Rate & Low Rate & No Further \\
\hline Water Levels in Lake Okeechobee & $\begin{array}{l}\text { No change in fish } \\
\text { abundance }\end{array}$ & $20 \%$ decrease & $60 \%$ decrease \\
\hline Water Levels in Estuaries & PW every years & $\begin{array}{c}\text { PW 1/ } 5 \\
\text { years }\end{array}$ & PW 1/ 30 years \\
\hline \multirow[t]{2}{*}{ Payment } & $\$ 0$ & $\$ 25$ & $\$ 70$ \\
\hline & Take No Action & Plan A & Plan B \\
\hline General Public Preferred Choice & $4(0.41 \%)$ & $39(4.02 \%)$ & $53(5.46 \%)$ \\
\hline General Public Total & \multicolumn{3}{|c|}{$96(9.90 \%)$} \\
\hline $\begin{array}{l}\text { Saltwater Anglers Preferred } \\
\text { Choice }\end{array}$ & $6(0.69 \%)$ & $44(5.04 \%)$ & $40(4.58 \%)$ \\
\hline Saltwater Anglers Total & \multicolumn{3}{|c|}{$90(10.31 \%)$} \\
\hline
\end{tabular}

Table 4.28: Choice Card 54 Decision

\begin{tabular}{|l|c|c|c|}
\cline { 2 - 4 } Choice Card Identification & \multicolumn{3}{|c|}{54} \\
\hline & Take No Action & Plan A & Plan B \\
\hline
\end{tabular}




\begin{tabular}{|c|c|c|c|}
\hline Municipal Water Demands & $15 \%$ decrease & $10 \%$ increase & No unmet demands \\
\hline Restrictions on Urban Expansion & Current Rate & Low Rate & No Further \\
\hline $\begin{array}{l}\text { Recreation in Everglades National } \\
\text { Park }\end{array}$ & $\begin{array}{l}10 \% \text { decrease in } \\
\text { access }\end{array}$ & $\begin{array}{c}10 \% \text { increase in } \\
\text { access }\end{array}$ & $\begin{array}{c}30 \% \text { increase in } \\
\text { access }\end{array}$ \\
\hline Recreation in Florida Bay & $\begin{array}{l}20 \% \text { decrease in } \\
\text { access }\end{array}$ & $5 \%$ increase in access & $\begin{array}{l}20 \% \text { increase in } \\
\text { access }\end{array}$ \\
\hline \multirow[t]{2}{*}{ Payment } & $\$ 0$ & $\$ 25$ & $\$ 50$ \\
\hline & Take No Action & Plan A & Plan B \\
\hline General Public Preferred Choice & $6(0.62 \%)$ & $42(4.33 \%)$ & $41(4.23 \%)$ \\
\hline General Public Total & \multicolumn{3}{|c|}{$89(9.18 \%)$} \\
\hline Saltwater Anglers Preferred Choice & $8(0.92 \%)$ & $39(4.47 \%)$ & $42(4.81 \%)$ \\
\hline Saltwater Anglers Total & \multicolumn{3}{|c|}{$89(10.19 \%)$} \\
\hline
\end{tabular}

Table 4.29: Choice Card 55 Decision

\begin{tabular}{|c|c|c|c|}
\hline \multirow[t]{2}{*}{ Choice Card Identification } & \multicolumn{3}{|c|}{55} \\
\hline & Take No Action & Plan A & Plan B \\
\hline Municipal Water Demands & $10 \%$ decrease & $5 \%$ increase & No unmet demands \\
\hline Restrictions on Urban Expansion & Current Rate & Low Rate & No Further \\
\hline $\begin{array}{l}\text { Recreation in Everglades National } \\
\text { Park }\end{array}$ & $\begin{array}{l}10 \% \text { decrease in } \\
\text { access }\end{array}$ & $\begin{array}{l}10 \% \text { increase in } \\
\text { access }\end{array}$ & $\begin{array}{l}40 \% \text { increase in } \\
\text { access }\end{array}$ \\
\hline Inland Mangrove Expansion & $30 \%$ increase & $10 \%$ increase & $10 \%$ decrease \\
\hline \multirow[t]{2}{*}{ Payment } & $\$ 0$ & $\$ 25$ & $\$ 70$ \\
\hline & Take No Action & Plan A & Plan B \\
\hline General Public Preferred Choice & $6(0.62 \%)$ & $33(3.40 \%)$ & $54(5.57 \%)$ \\
\hline General Public Total & \multicolumn{3}{|c|}{$93(9.59 \%)$} \\
\hline Saltwater Anglers Preferred Choice & $4(0.46 \%)$ & $30(3.44 \%)$ & $41(4.70 \%)$ \\
\hline Saltwater Anglers Total & \multicolumn{3}{|c|}{$75(8.59 \%)$} \\
\hline
\end{tabular}

Table 4.30: Choice Card 56 Decision

\begin{tabular}{l|c|c|c|}
\cline { 2 - 3 } $\begin{array}{l}\text { Choice Card } \\
\text { Identification }\end{array}$ & \multicolumn{2}{c}{$\mathbf{2}$} \\
\hline \multirow{2}{*}{ Municipal Water Demands } & Take No Action & Plan A & Plan B \\
\hline Restrictions on Urban Expansion & $15 \%$ decrease & $10 \%$ increase & No unmet demands \\
\hline Recreation in Florida Bay & Current Rate & Low Rate & No Further \\
\hline Inland Mangrove Expansion & $\begin{array}{c}10 \% \text { decrease in } \\
\text { access }\end{array}$ & $\begin{array}{c}5 \% \text { increase in } \\
\text { access }\end{array}$ & $20 \%$ increase in access \\
\hline Payment & $20 \%$ increase & $10 \%$ increase & $5 \%$ decrease \\
\hline \multirow{2}{*}{ General Public Preferred Choice } & $\$ 0$ & $\$ 25$ & $\$ 50$ \\
\cline { 2 - 4 } & Take No Action & Plan A & Plan B \\
\hline
\end{tabular}




\begin{tabular}{|c|c|c|c|}
\hline General Public Total & \multicolumn{3}{|c|}{$92(9.48 \%)$} \\
\hline $\begin{array}{l}\text { Saltwater Anglers Preferred } \\
\text { Choice }\end{array}$ & $3(0.34 \%)$ & $40(4.58 \%)$ & $42(4.81 \%)$ \\
\hline Saltwater Anglers Total & \multicolumn{3}{|c|}{$85(9.74 \%)$} \\
\hline
\end{tabular}

Table 4.31: Choice Card 57 Decision

\begin{tabular}{|c|c|c|c|}
\hline \multirow{2}{*}{$\begin{array}{l}\text { Choice Card } \\
\text { Identification }\end{array}$} & \multicolumn{3}{|c|}{57} \\
\hline & Take No Action & Plan A & Plan B \\
\hline Urban Flood Risk & $\begin{array}{c}\text { Flooding } 1 / 20 \\
\text { years }\end{array}$ & Flooding $1 / 7$ years & Flooding $1 / 5$ years \\
\hline Restrictions on Urban Expansion & Current Rate & Low Rate & No Further \\
\hline Water Levels in Lake Okeechobee & No change & $\begin{array}{l}40 \% \text { decrease in } \\
\text { fish }\end{array}$ & $80 \%$ decrease in fish \\
\hline Water Levels in Estuaries & PW every year & PW 1 / 5 years & PW 1 / 30 years \\
\hline \multirow[t]{2}{*}{ Payment } & $\$ 0$ & $\$ 35$ & $\$ 70$ \\
\hline & Take No Action & Plan A & Plan B \\
\hline General Public Preferred Choice & $5(0.52 \%)$ & $41(4.23 \%)$ & $50(5.15 \%)$ \\
\hline General Public Total & \multicolumn{3}{|c|}{$96(9.90 \%)$} \\
\hline $\begin{array}{l}\text { Saltwater Anglers Preferred } \\
\text { Choice }\end{array}$ & $7(0.80 \%)$ & $33(3.78 \%)$ & $50(5.73 \%)$ \\
\hline Saltwater Anglers Total & \multicolumn{3}{|c|}{$90(10.31 \%)$} \\
\hline
\end{tabular}

Table 4.32: Choice Card 58 Decision

\begin{tabular}{|c|c|c|c|}
\hline \multirow[t]{2}{*}{ Choice Card Identification } & \multicolumn{3}{|c|}{58} \\
\hline & Take No Action & Plan A & Plan B \\
\hline Urban Flood Risk & $\begin{array}{c}\text { Flooding every } 1 / 15 \\
\text { years }\end{array}$ & Flooding $1 / 7$ years & $\begin{array}{l}\text { Flooding } 1 / 2 \\
\text { years }\end{array}$ \\
\hline Restrictions on Urban Expansion & Current Rate & Low Rate & No Further \\
\hline $\begin{array}{l}\text { Recreation in Everglades National } \\
\text { Park }\end{array}$ & $10 \%$ decrease in access & $\begin{array}{l}20 \% \text { increase in } \\
\text { access }\end{array}$ & $\begin{array}{l}40 \% \text { increase in } \\
\text { access }\end{array}$ \\
\hline Recreation in Florida Bay & $10 \%$ decrease in access & $\begin{array}{c}10 \% \text { increase in } \\
\text { access }\end{array}$ & $\begin{array}{c}30 \% \text { increase in } \\
\text { access }\end{array}$ \\
\hline \multirow[t]{2}{*}{ Payment } & $\$ 0$ & $\$ 35$ & $\$ 70$ \\
\hline & Take No Action & Plan A & Plan B \\
\hline General Public Preferred Choice & $10(1.03 \%)$ & $22(2.27 \%)$ & $68(7.01 \%)$ \\
\hline General Public Total & \multicolumn{3}{|c|}{$100(10.31 \%)$} \\
\hline Saltwater Anglers Preferred Choice & $12(1.37 \%)$ & $42(4.81 \%)$ & $39(4.47 \%)$ \\
\hline Saltwater Anglers Total & \multicolumn{3}{|c|}{$93(10.65 \%)$} \\
\hline
\end{tabular}


Table 4.33: Choice Card 59 Decision

\begin{tabular}{|c|c|c|c|}
\hline \multirow[t]{2}{*}{ Choice Card Identification } & \multicolumn{3}{|c|}{59} \\
\hline & Take No Action & Plan A & Plan B \\
\hline Urban Flood Risk & Flooding $1 / 20$ years & Flooding $1 / 7$ years & Flooding $1 / 2$ years \\
\hline Restrictions on Urban Expansion & Current Rate & Low Rate & No Further \\
\hline $\begin{array}{l}\text { Recreation in Everglades National } \\
\text { Park }\end{array}$ & $\begin{array}{l}10 \% \text { decrease in } \\
\text { access }\end{array}$ & $\begin{array}{l}20 \% \text { increase in } \\
\text { access }\end{array}$ & $\begin{array}{l}40 \% \text { increase in } \\
\text { access }\end{array}$ \\
\hline Inland Mangrove Expansion & $20 \%$ increase & $10 \%$ increase & $10 \%$ decrease \\
\hline \multirow[t]{2}{*}{ Payment } & $\$ 0$ & $\$ 35$ & $\$ 70$ \\
\hline & Take No Action & Plan A & Plan B \\
\hline General Public Preferred Choice & $14(1.44 \%)$ & $39(4.025)$ & $50(5.15 \%)$ \\
\hline General Public Total & \multicolumn{3}{|c|}{$103(10.62 \%)$} \\
\hline Saltwater Anglers Preferred Choice & $11(1.26 \%)$ & $41(4.70 \%)$ & $37(4.24 \%)$ \\
\hline Saltwater Anglers Total & \multicolumn{3}{|c|}{$89(10.19 \%)$} \\
\hline
\end{tabular}

\section{Table 4.34: Choice Card 60 Decision}

\begin{tabular}{|c|c|c|c|c|}
\hline Choice Card Identification & \multicolumn{4}{|c|}{60} \\
\hline & Take No Action & \multicolumn{2}{|c|}{ Plan A } & Plan B \\
\hline Urban Flood Risk & Flooding 1 / 20 years & \multicolumn{2}{|c|}{ Flooding 1 / 10 years } & Flooding $1 / 5$ years \\
\hline Restrictions on Urban Expansion & Current Rate & \multicolumn{2}{|c|}{ Low Rate } & No Further \\
\hline Recreation in Florida Bay & $20 \%$ decrease in access & \multicolumn{2}{|c|}{$5 \%$ increase in access } & $20 \%$ increase in access \\
\hline Inland Mangrove Expansion & $20 \%$ increase & \multicolumn{2}{|c|}{$5 \%$ increase } & $5 \%$ decrease \\
\hline Payment & $\$ 0$ & \multicolumn{2}{|c|}{$\$ 25$} & $\$ 50$ \\
\hline & Take No Action & \multicolumn{2}{|c|}{ Plan A } & Plan B \\
\hline General Public Preferred Choice & $9(0.93 \%)$ & \multicolumn{2}{|c|}{$40(4.12 \%)$} & $50(5.15 \%)$ \\
\hline General Public Total & \multicolumn{4}{|c|}{$99(10.21 \%)$} \\
\hline Saltwater Anglers Preferred Choice & $4(0.46 \%)$ & \multicolumn{2}{|c|}{$46(5.27 \%)$} & $46(5.27 \%)$ \\
\hline Saltwater Anglers Total & \multicolumn{4}{|c|}{$96(11.00 \%)$} \\
\hline Subtotal & \multicolumn{2}{|c|}{$\begin{array}{c}\text { General Public } \\
\text { Take No Action: } 85(8.76 \%) \\
\text { Plan A: } 362(37.32 \%) \\
\text { Plan B: } 523(53.92 \%) \\
\text { n }=970\end{array}$} & \multicolumn{2}{|c|}{$\begin{array}{c}\text { Saltwater Anglers } \\
\text { Take No Action: } 68(7.79 \%) \\
\text { Plan A: } 398(45.59 \%) \\
\text { Plan B: } 407(46.62 \%) \\
\text { n = 873 }\end{array}$} \\
\hline
\end{tabular}




\subsection{Regression Analysis}

\subsubsection{Variable Descriptions}

Before examining the regression analysis, Table 4.35 lists the variables listed in Table 4.36- Table 4.39, or the regression analysis tables.

Table 4.35: Variable Description List Used in Regression Analysis

\begin{tabular}{|c|c|c|c|c|c|}
\hline Variable Name & $\begin{array}{l}\text { Variable } \\
\text { Description }\end{array}$ & Variable Name & $\begin{array}{l}\text { Variable } \\
\text { Description }\end{array}$ & Variable Name & $\begin{array}{l}\text { Variable } \\
\text { Description }\end{array}$ \\
\hline $\begin{array}{l}\text { Lake } \\
\text { Okeechobee }\end{array}$ & & Wetland Species & $\begin{array}{l}\text { Restoration } \\
\text { Plan Attribute }\end{array}$ & Income & $\begin{array}{l}\text { Categorical } \\
\text { variable; } \\
\text { income } \\
\text { increasing 1- } \\
20\end{array}$ \\
\hline $\begin{array}{l}\text { Water } \\
\text { Conservation } \\
\text { Areas }\end{array}$ & $\begin{array}{l}\text { Restoration } \\
\text { Plan } \\
\text { Attribute }\end{array}$ & Dry land Species & $\begin{array}{l}\text { Restoration } \\
\text { Plan Attribute }\end{array}$ & Age & $\begin{array}{l}\text { Continuous } \\
\text { Variable for } \\
\text { actual age of } \\
\text { respondents }\end{array}$ \\
\hline $\begin{array}{l}\text { Everglades } \\
\text { National Park }\end{array}$ & $\begin{array}{l}\text { Restoration } \\
\text { Plan } \\
\text { Attribute }\end{array}$ & $\begin{array}{l}\text { Florida Bay } \\
\text { Species }\end{array}$ & $\begin{array}{l}\text { Restoration } \\
\text { Plan Attribute }\end{array}$ & Gender & $\begin{array}{l}1=\text { Male } \\
2=\text { Female }\end{array}$ \\
\hline $\begin{array}{l}\text { Restrictions on } \\
\text { Water Usage }\end{array}$ & $\begin{array}{l}\text { Restoration } \\
\text { Plan } \\
\text { Attribute (in } \\
\text { both Hydro } \\
\text { and Species } \\
\text { Model) }\end{array}$ & PoliticalParty & $\begin{array}{l}1= \\
\text { Democratic } \\
\text { Party } \\
\text { 2= Republican } \\
\text { Party } \\
\text { 3=Independen } \\
\text { t 4= Other } \\
\text { 5= Not } \\
\text { Interested in } \\
\text { Politics }\end{array}$ & Race & $\begin{array}{l}\text { 1= Caucasian } \\
2=\text { African } \\
\text { American } \\
3=\text { Hispanic } \\
\text { 4=Asian } \\
5=\text { Native } \\
\text { American } \\
\text { 6=Pacific } \\
\text { Islander } \\
7=\text { Other } \\
8=\text { Choose not } \\
\text { to Indicate }\end{array}$ \\
\hline Payment & $\begin{array}{l}\text { Cost of } \\
\text { restoration } \\
\text { plan } \\
\text { (annually } \\
\text { for } 10 \\
\text { years) }\end{array}$ & SureChoice & $\begin{array}{l}\text { Sureness of } \\
\text { decision for } \\
\text { plan } 1-5 ; 1= \\
\text { Completely } \\
\text { Unsure } \\
5= \\
\text { Completely } \\
\text { Sure }\end{array}$ & Education & $\begin{array}{l}\text { 1=Less than } \\
\text { High School } \\
\text { Diploma } \\
\text { 2=High } \\
\text { School } \\
\text { Diploma/GED } \\
\text { 3=2- year } \\
\text { College }\end{array}$ \\
\hline Plan & $\begin{array}{l}\text { Represents } \\
\text { plan in data } \\
\text { set; } 1-2 \text { in } \\
\text { hydro and }\end{array}$ & $\begin{array}{l}\text { RA_VisitBeach } \\
\text { (insert various } \\
\text { recreational } \\
\text { activities) }\end{array}$ & $\begin{array}{l}\text { Frequency of } \\
\text { recreational } \\
\text { activities; } 1-7 \\
1=\text { More than }\end{array}$ & & $\begin{array}{l}\text { Degree } \\
4=4-\text { year } \\
\text { College } \\
\text { Degree }\end{array}$ \\
\hline
\end{tabular}




\begin{tabular}{|c|c|c|c|c|c|}
\hline & $\begin{array}{l}\text { species } \\
\text { card; } 1-3 \text { in } \\
\text { managemen } \\
t \text { cards }\end{array}$ & & $\begin{array}{l}\text { once a week } \\
7=\text { Never }\end{array}$ & & $\begin{array}{l}5=\text { Master's } \\
\text { Degree } \\
\text { 6=Professiona } \\
\text { 1 Degree } \\
\text { 7= Doctoral } \\
\text { Degree }\end{array}$ \\
\hline $\begin{array}{l}\text { YearsResidenc } \\
\text { e inFL }\end{array}$ & $\begin{array}{l}\text { Continuous } \\
\text { Variable for } \\
\text { years lived } \\
\text { in FL }\end{array}$ & WS_MyComm & $\begin{array}{l}\text { Strongly } \\
\text { Disagree- } \\
\text { Strongly } \\
\text { Agree } \\
\text { (Range 1-5) } \\
\text { In } 10 \text { yrs, } \\
\text { there will not } \\
\text { be enough } \\
\text { water for my } \\
\text { community }\end{array}$ & Visit_ENP & $\begin{array}{l}\text { Yes }=1 \\
\text { No=2 } \\
\text { Have you } \\
\text { visited ENP? }\end{array}$ \\
\hline EnvEcon & $\begin{array}{l}\text { Preferences } \\
\text { for Public } \\
\text { Policy } \\
\text { (Range 1-7) } \\
1= \\
\text { Protecting } \\
\text { the Env } \\
7= \\
\text { Economic } \\
\text { Growth }\end{array}$ & WS_FL & $\begin{array}{l}\text { Strongly } \\
\text { Disagree- } \\
\text { Strongly } \\
\text { Agree } \\
\text { (Range 1-5) } \\
\text { In } 10 \text { yrs, } \\
\text { there will not } \\
\text { be enough } \\
\text { water for } \\
\text { Florida } \\
\end{array}$ & $\begin{array}{l}\text { Recreation_EN } \\
\text { P }\end{array}$ & $\begin{array}{l}\text { Yes }=1 \\
\text { No=2 } \\
\text { Participation } \\
\text { in recreational } \\
\text { activities in } \\
\text { ENP }\end{array}$ \\
\hline WS_ENV & $\begin{array}{l}\text { Strongly } \\
\text { Disagree- } \\
\text { Strongly } \\
\text { Agree } \\
\text { (Range 1-5) } \\
\text { The Env is } \\
\text { very } \\
\text { delicate and } \\
\text { can easily } \\
\text { shift out of } \\
\text { balance }\end{array}$ & $\begin{array}{l}\text { 1stVUnderstood } \\
\text { / } \\
\text { 2ndVUnderstoo } \\
\text { d } \\
\text { (How well did } \\
\text { you understand } \\
1^{\text {st }} \text { and } 2^{\text {nd }} \\
\text { Videos?- Range } \\
1-5 \text { ) }\end{array}$ & $\begin{array}{l}1= \\
\text { Completely } \\
\text { did not } \\
\text { Understand } \\
5= \\
\text { Completely } \\
\text { Understood }\end{array}$ & $\begin{array}{l}\text { 1stVFamiliar } \\
\text { (How familiar } \\
\text { are you with the } \\
\text { content of } 1^{\text {st }} \\
\text { Video?) }\end{array}$ & $\begin{array}{l}1=\text { Not at all } \\
\text { Familiar } \\
\text { 5- Very } \\
\text { Familiar }\end{array}$ \\
\hline
\end{tabular}

\subsubsection{General Public Sample Population Regression Analysis}

The following table (Table 4.36) displays the results from Model 1-4 of the hydrological model within the general public sample population. 


\section{Table 4.36: Regression Output for Hydrological Model- General Public ${ }^{1}$}

\begin{tabular}{|c|c|c|c|c|}
\hline \multicolumn{5}{|c|}{ General Public Sample Population Regression Output for Species Model- Milon et al(1999) adapted } \\
\hline \multirow[t]{2}{*}{ Variables } & \multicolumn{2}{|c|}{ Robust Logit Model } & \multicolumn{2}{|c|}{$\begin{array}{l}\text { Mixed Logit Models- } \\
\text { Heterogeneity controlled for at } \\
\text { YearsResidenceinFL }\end{array}$} \\
\hline & (1) & (2) & (3) & (4) \\
\hline cons & $\begin{array}{c}-.5877 * * \\
(.2908)\end{array}$ & $\begin{array}{l}-.5159 \\
(.3724)\end{array}$ & $\begin{array}{c}-.6955^{* *} \\
(.3686)\end{array}$ & $\begin{array}{l}-.2609 \\
(.3987)\end{array}$ \\
\hline Lake Okeechobee & $\begin{array}{l}-.0006 \\
(.0033)\end{array}$ & $\begin{array}{c}-0034 \\
(.0035)\end{array}$ & $\begin{array}{l}-.0023 \\
(.0035)\end{array}$ & $-.0018(.0036)$ \\
\hline Water Conservation Areas & $\begin{array}{c}.0082 * * * \\
(.0022)\end{array}$ & $\begin{array}{c}-.0065^{* * *} \\
(.0025)\end{array}$ & $\begin{array}{c}.0066 * * * \\
(.0025)\end{array}$ & $\begin{array}{c}.0069 * * * \\
(.0026)\end{array}$ \\
\hline Everglades National Park & $-.0013(0024)$ & $-.0029(.0026)$ & $-.0027(.0026)$ & $-.0024(.0026)$ \\
\hline Restrictions on Water Usage & $-.08156(.0639)$ & $-.1012(.0671)$ & $-.1027(.0676)$ &.$- .1022(.0682)$ \\
\hline Payment & $-.0032 *(.0019)$ & $-.0051 * *(.0023)$ & $\begin{array}{c}-.0046^{* *} \\
(.0023)\end{array}$ & $\stackrel{-}{-} .0049 * *(.0023)$ \\
\hline Income & $\begin{array}{c}.1042 * * * \\
(.0081)\end{array}$ & $.0721 * * *(.0087)$ & $\begin{array}{c}.0737 * * * \\
(.0087)\end{array}$ & $\begin{array}{c}.0610 * * * \\
(.0089)\end{array}$ \\
\hline Plan & & $.2630 * *(.1248)$ & $\begin{array}{l}2269^{*} \\
(.1279)\end{array}$ & $.2218 *(.0089)$ \\
\hline Age & & $.0125 * * *(.0029)$ & $\begin{array}{c}.0131 * * * \\
(.0022)\end{array}$ & $\begin{array}{c}.0137 * * *(.0024 \\
)\end{array}$ \\
\hline Gender & & $-.3490 * * *(.0709)$ & $\begin{array}{c}-.3548 * * * \\
(.0712)\end{array}$ & $\begin{array}{c}-.3290 * * * \\
(.0741)\end{array}$ \\
\hline YearsResidence inFL & & $-.0007 * *(.0004)$ & $-.0011(.0008)$ & $\begin{array}{l}-.0010 \\
(.0008)\end{array}$ \\
\hline Race & & $-.1051 * * *(.0242)$ &.- & - \\
\hline Education & & $.1254 * * *(.0287)$ & $\begin{array}{c}.1214 * * * \\
(.0289)\end{array}$ & $\begin{array}{c}.0945 * * * \\
(.0296)\end{array}$ \\
\hline PoliticalParty & & $-.0173(.0264)$ & $-.0325(.0269)$ & $-0350(.0274)$ \\
\hline RA_VisitBeach & & & & $-.0200(.0262)$ \\
\hline RA_Fishing & & & & $.0115(.0250)$ \\
\hline $\mathrm{RA}_{-}^{-}$Boating & & & & $-.0353(.0250)$ \\
\hline RA_PaddleBoarding & & & & $.1000 * * *(.0375$ \\
\hline RA_ScubaDiving & & & & $.1000 * *(.0458)$ \\
\hline RA_FreeDive & & - & & $.0282(.0467)$ \\
\hline RA_Snorkeling & & & & $\begin{array}{c}-.1598 * * * \\
(.0381)\end{array}$ \\
\hline RA_Swimming & & & & $\begin{array}{l}-.0118 \\
(.0249)\end{array}$ \\
\hline
\end{tabular}

$1 *$ indicates significance at $0.10, * *$ indicates significance at $0.05, * * *$ indicates significance at 0.01 
RA_Kayaking

(1) Model (1) displays the results of a robust logit regression model that included the full set of hydrological restoration attributes with an exception. Notice that the "Farmland Acreage" attribute was excluded from Model (1) due to high levels of correlation with the bid value

$(r=0.94)$. This high correlation poses a collinearity issue within the regression analysis and therefore had to be excluded. Within the set of hydrological restoration attributes, only the "Water Conservation Areas" attribute elicited a significant, positive co-efficient, while the payment attribute also elicited a significant, yet negative co-efficient. The income variable is also positively significant, which follows the expected trend of higher income respondents exhibiting a higher $W T P$.

(2) Model (2) exhibits the results from another robust logit model that includes all the variables from Model (1) and a few other demographic variables. Despite the additional variables in Model (2), the "Water Conservation Areas" attribute remained the only significant positive indicator on the dependent variable, or the decision to pay for restoration plans. Unlike Model (1) the constant is not significant, indicating that Model (2) has captured the effects on the dependent variable. The Age and Education variables were all positively, significant indicators on the dependent variable, while Gender, YearsResidencesinFl, and Race were all negatively, significant indicators. 
(3) Model (3) displays the results of a mixed logit model controlling for heterogeneity within the "YearsResidenceinFL" variable. Model (3) contains all the variables from Model (2) with the exception of the "Race" variable. As in Model (2), the significant variables maintain their significance in their respective direction, with the exception of the YearsResidencesinFL, which lost its significance. However, the constant variable is once again significant in Model (3), as in Model (1). Furthermore, the "Water Conservation Areas" attribute remained the only significant attribute in the selection of hydrological restoration attributes.

(4) Model (4) displays the output from the final mixed logit model controlling for heterogeneity within the "YearsResidenceinFL" variable. Model (4) contains the same variables from Model (3), with the inclusion of the various frequencies of recreational activities variables. The constant term is not significant within Model (4), but once again, the inclusion of more variables does not alter the observed effects on the dependent variable. As for recreational activities, although $R A \_$Paddleboarding and $R A \_$ScubaDiving are positively significant, the frequency of these recreational activities decreasing amongst respondents is significant. While this reasoning is counter-intuitive, it results from the coding of the recreational activities which records participation within these activities in a descending fashion (i.e, $1=$ More than once a week, while $7=$ Never). In the same reasoning, $R A \_$Snorkeling and $R A \_$Kayaking are negatively significant, yet this outcome indicates that as frequency of participation increases within these activities amongst respondents, they are influenced to pay for hydrological restoration. 
The following table (Table 4.37) displays the results from Model 5-9 of the species model within the general public sample population.

\section{Table 4.37: Regression Output for Species Model- General Public ${ }^{2}$}

\begin{tabular}{|c|c|c|c|c|c|}
\hline \multicolumn{6}{|c|}{$\begin{array}{l}\text { General Public Sample Population Regression Output for Species Model- Milon et al. (1999) } \\
\text { adapted }\end{array}$} \\
\hline \multirow[t]{2}{*}{ Variables } & \multicolumn{2}{|c|}{ Logit Models (Robust) } & \multicolumn{3}{|c|}{$\begin{array}{l}\text { Mixed Logit- Heterogeneity Controlled for } \\
\text { and County }(7) \text { and Age }(8,9)\end{array}$} \\
\hline & (5) & (6) & (7) & (8) & (9) \\
\hline cons & $\begin{array}{c}-.9852 * * * \\
(.3018)\end{array}$ & $\begin{array}{c}1.3068^{* * *} \\
(.4215)\end{array}$ & $\begin{array}{c}1.319 * * * \\
(.4244)\end{array}$ & $\begin{array}{c}1.219 * * * \\
(.4514)\end{array}$ & $\begin{array}{c}-3.617 * * * \\
(.6801)\end{array}$ \\
\hline Wetland Species & $\begin{array}{c}.0052^{* * *} \\
(.0017)\end{array}$ & $\begin{array}{l}.0034^{*} \\
(.0019)\end{array}$ & $\begin{array}{l}.0033^{*} \\
(.0019)\end{array}$ & $\begin{array}{l}.0039^{* *} \\
(.0019)\end{array}$ & $\begin{array}{l}.0034^{*} \\
(.0020)\end{array}$ \\
\hline Dry land Species & $\begin{array}{l}.0058^{*} \\
(.0033)\end{array}$ & $\begin{array}{l}.0064^{*} \\
(.0038)\end{array}$ & $\begin{array}{l}.0066^{*} \\
(.0038)\end{array}$ & $\begin{array}{l}.0066^{*} \\
(.0038)\end{array}$ & $\begin{array}{l}.0060 \\
(.0039)\end{array}$ \\
\hline $\begin{array}{l}\text { Florida Bay } \\
\text { Species }\end{array}$ & $\begin{array}{l}.0041 \\
(.0029)\end{array}$ & $\begin{array}{l}.0053 \\
(.0033)\end{array}$ & $\begin{array}{l}.0531 \\
(.0033)\end{array}$ & $\begin{array}{l}.0061^{*} \\
(.0034)\end{array}$ & $\begin{array}{l}.0066^{*} \\
(.0035)\end{array}$ \\
\hline $\begin{array}{l}\text { Restrictions on } \\
\text { Water Usage }\end{array}$ & $\begin{array}{l}.2120^{*} \\
(.1196)\end{array}$ & $\begin{array}{l}.2749 * * \\
(.1344)\end{array}$ & $\begin{array}{c}.22851 * * \\
(.1368)\end{array}$ & $\begin{array}{l}.2213 \\
(.1399)\end{array}$ & $\begin{array}{l}.2639^{*} \\
(.1435)\end{array}$ \\
\hline Payment & $\begin{array}{c}-.0177 * * * \\
(.0037)\end{array}$ & $\begin{array}{c}-.0211^{* * * *} \\
(.0041)\end{array}$ & $\begin{array}{c}-.0214 * * * \\
(.0042)\end{array}$ & $\begin{array}{c}-.0205^{* * *} \\
(.0043)\end{array}$ & $\begin{array}{c}-.0218^{* * * *} \\
(.0044)\end{array}$ \\
\hline Income & $\begin{array}{c}.0912 * * * \\
(.0079)\end{array}$ & $\begin{array}{c}.0623 * * * \\
(.0089)\end{array}$ & $\begin{array}{c}.0622 * * * \\
(.0090)\end{array}$ & $\begin{array}{c}.0636^{* * *} \\
(.0089)\end{array}$ & $\begin{array}{c}.0459 * * * \\
(.0097)\end{array}$ \\
\hline Age & & $\begin{array}{c}.0084 * * * \\
(.0022)\end{array}$ & $\begin{array}{c}.0084^{* * * *} \\
(.0036)\end{array}$ & $\begin{array}{c}.0102 * * * \\
(.0036)\end{array}$ & $\begin{array}{l}.0064^{*} \\
(.0035)\end{array}$ \\
\hline Gender & & $\begin{array}{c}-.4490 * * * \\
(.0770)\end{array}$ & $\begin{array}{c}-.4601 * * * \\
(.0778)\end{array}$ & $\begin{array}{c}-.4334 * * * \\
(.0791)\end{array}$ & $\begin{array}{c}-.3758 * * * \\
(.0820)\end{array}$ \\
\hline $\begin{array}{l}\text { Years Residence } \\
\text { in FL }\end{array}$ & & $\begin{array}{c}-.0015^{* * *} \\
(.0005)\end{array}$ & $\begin{array}{l}-.0015 \\
(.0010)\end{array}$ & $\begin{array}{l}-.0013 \\
(.0011)\end{array}$ & $\begin{array}{l}-.0017 \\
(.0016)\end{array}$ \\
\hline Political Party & & $\begin{array}{c}-.1190 * * * \\
(.0286)\end{array}$ & $\begin{array}{c}-.0122 * * * \\
(.0293)\end{array}$ & $\begin{array}{c}.0120 * * * \\
(.0302)\end{array}$ & $\begin{array}{c}-.0963 * * * \\
(.0313)\end{array}$ \\
\hline Visit_ENP & & $\begin{array}{c}-.2069^{* *} \\
(.0972)\end{array}$ & $\begin{array}{c}-.1984 * * \\
(.0962)\end{array}$ & $\begin{array}{c}-.2392 * * \\
(.0989)\end{array}$ & $\begin{array}{l}-.1503 \\
(.1015)\end{array}$ \\
\hline Recreation_ENP & & $\begin{array}{c}-.2882 * * * \\
(.0944)\end{array}$ & $\begin{array}{c}-.2922 * * * \\
(.0928)\end{array}$ & $\begin{array}{c}-.2866 * * * \\
(.0951)\end{array}$ & $\begin{array}{l}-.1515 \\
(.0989)\end{array}$ \\
\hline EnvEcon & & $\begin{array}{c}-.2811 * * * \\
(.0260)\end{array}$ & $\begin{array}{c}-.2806^{* * *} \\
(.0251)\end{array}$ & $\begin{array}{c}-.2781 * * * \\
(.0256)\end{array}$ & $\begin{array}{c}-.2031 * * * \\
(.0270)\end{array}$ \\
\hline WS_MyCom & & & & & $\begin{array}{l}.1016^{* *} \\
(.0526)\end{array}$ \\
\hline WS_FL & & & & & .0166 \\
\hline
\end{tabular}

$2 *$ indicates significance at $0.10, * *$ indicates significance at $0.05, * * *$ indicates significance at 0.01 


\begin{tabular}{lc}
\hline \multirow{2}{*}{ WS_ENV } & $(.0526)$ \\
& $.2131^{* * *}$ \\
1stVUnderstood & $(.0439)$ \\
& $.1567^{* * *}$ \\
1stVFamiliar & $(.0621)$ \\
& $.1509^{* * *}$ \\
2ndVUnderstood & $(.0455)$ \\
& $.1113^{* * *}$ \\
& $(.0280)$ \\
\hline
\end{tabular}

(5) Model 5 displays the results from a robust logit model regression, which includes the full set of species population restoration attributes, once again excluding the "Farmland Acreage" attribute. As with the hydrological model, the "farmland acreage" attribute posed a collinearity issue with its high correlation $(r=0.90)$ to the bid value. Of the restoration attributes, three out of the four included species restoration attributes proved to be significant, positive indicators on the dependent variable, Wetland Species, Dry land Species, and Restrictions on Water Usage. Additionally, the payment attribute and then income variable yielded significant results in line with normal trends, or a negatively significant payment attribute and a positively significant income variable.

(6) Model 6 also displays the results from a robust logit model including the full set of species restoration attributes (with the exception of Farmland Acreage) and key demographic variables, and variables describing visitation to the Everglades and recreation within the Everglades. The Wetland Species, Dry Land Species, and Restrictions on Water Usage attribute remained significant, as well as the payment attribute, and the income variable. The Age variable proved to be the only positively significant demographic consideration, while the Gender, YearInResidenceFl, 
PoliticalParty, Visit_ENP, RecreationENP, and the EnvEcon variable proved to be negatively significant indicators on the dependent variable.

(7) Model 7 displays the output of a mixed logit model controlled for heterogeneity at the County variable, or level. This model contains all the variables within Model (6). In this model, the Wetland Species, Dry Land Species, and Restrictions on Water Usage attributes continued to show positive significance. While not referenced within Table 4.37, the Florida Bay Species attribute is leaning significant $(p=.108)$, but not quite significant at the $\alpha=0.10$ level. All of the other variables remained significant as they appeared in Model (6), within the exception of the YearInResidenceFl variable, which lost its significance.

(8) Model 8 showcases the results of another mixed logit model, yet controlling for heterogeneity within the Age variable, and containing the same variables as Models (6) and (7). However, by controlling for heterogeneity within the Age variable, the significance within the Restrictions on Water Usage did not hold constant as it did in Models (5), (6), and (7). Instead, the Florida Bay Species, an attribute that was borderline significant in Model (7), displayed positive, significance in Model (8). All other variables that were significant Model (7) held their significance in Model (8).

(9) The final model within the species model for the general public sample, Model (9), also displays the results of a mixed logit model controlling for heterogeneity within the Age variable. Model (9) includes all the variables from Model (8) with a few additional variables such as WS_MyComm, WS_FL, WS_ENV, 1stVUnderstood, 1stVFamiliar, and 2ndVUnderstood. The first three variables describe statements about water supply and the 
last three variables measure how well respondents understood the videos embedded within the survey and how familiar they were with the content in the video. The inclusion of these variables in conjunction with the variables from Model (8) led to the loss of significance in the Dry Land Species attribute, and the re-gaining of significance within the Restrictions on Water Usage attribute. The Florida Bay Species attribute remained significant from Model (8). Furthermore, the WS_MyComm, WS_ENV, 1stVUnderstood, 1stVFamiliar, and 2ndVUnderstood all produced significantly positive effects on the dependent variable.

\subsubsection{Saltwater Anglers Sample Population Regression Analysis}

The following table (Table 4.38) displays the results from Model 10-14 of the hydrological model within the saltwater anglers sample population.

Table 4.38: Regression Output for Hydrological Model- Saltwater Anglers ${ }^{3}$

\begin{tabular}{lccccc}
\hline \multicolumn{2}{c}{ Saltwater Angler Sample Population Regression Output for Hydrological Model- Milon et al. (1999) } \\
adapted
\end{tabular}

\footnotetext{
$3 *$ indicates significance at $0.10, * *$ indicates significance at $0.05, * * *$ indicates significance at 0.01
} 


\begin{tabular}{|c|c|c|c|c|c|}
\hline Plan & $\begin{array}{c}1.078 * * * \\
(.2237)\end{array}$ & $\begin{array}{c}1.1549 * * * \\
(.2304)\end{array}$ & $\begin{array}{c}1.160 * * * \\
(.2441)\end{array}$ & $\begin{array}{c}1.2907 * * * \\
(.2333)\end{array}$ & $\begin{array}{c}1.318^{* * * *} \\
(.2510)\end{array}$ \\
\hline Age & & $-.0027(.0047)$ & $.0039(.0056)$ & $-.0014(.0053)$ & $.0030(.0062)$ \\
\hline Gender & & $-.2022(.1466)$ & $-.2545(.1638)$ & $-.1945(.1545)$ & $-.2341(.1726)$ \\
\hline $\begin{array}{l}\text { YearsResidence } \\
\text { inFL }\end{array}$ & & $.0015(.0034)$ & $-.0010(.0038)$ & $.0026(.0037)$ & $.0011(.0041)$ \\
\hline Race & & $\begin{array}{c}- \\
.1098^{*} *(.0293)\end{array}$ & $\begin{array}{c}-.1082 * * * \\
(.0333)\end{array}$ & $\begin{array}{c}-.1058 * * * \\
(.0332)\end{array}$ & $\begin{array}{c}-.1061 * * * \\
(.0344)\end{array}$ \\
\hline Education & & $.0521(.0395)$ & $.0002(.0432)$ & $.0463(.0423)$ & $.0016(.0434)$ \\
\hline PoliticalParty & & $.1460 * * *(.0476)$ & $\begin{array}{c}-.1710^{* * *} \\
(.0510)\end{array}$ & $\begin{array}{c}-.1857 * * * \\
(.0548)\end{array}$ & $\begin{array}{c}-.1876^{* * *} \\
(.0568)\end{array}$ \\
\hline SureChoice & & & $\begin{array}{c}.8008 * * * \\
(.0760)\end{array}$ & $.8259 * * *(.0762)$ & $\begin{array}{c}.8672 * * * \\
(.0788)\end{array}$ \\
\hline $\begin{array}{l}\text { RA } \\
\text { VisitBeach }\end{array}$ & & & $-.0075(.0471)$ & & $-.0023(.0503)$ \\
\hline RA_Fishing & & & $.0679(.0586)$ & & $.0800(.0630)$ \\
\hline $\mathrm{RA}^{-}$Boating & & & $-.0472(.0497)$ & & $-.0751(.0524)$ \\
\hline $\begin{array}{l}\mathrm{RA}^{-} \\
\text {PaddleBoarding }\end{array}$ & & & $.1006 * *(.0434)$ & & $.1234 * * *(.0460)$ \\
\hline $\begin{array}{l}\text { RA } \\
\text { ScubaDiving }\end{array}$ & & & $-.0555(.0456)$ & & $-.0422(.0498)$ \\
\hline RA_FreeDive & & & $-.0917 * *(.0474)$ & & $-.0854(.0526)$ \\
\hline $\begin{array}{l}\mathrm{RA}_{-} \\
\text {Snorkeling }\end{array}$ & & & $.0306(.0556)$ & & $.0328(.0580)$ \\
\hline $\begin{array}{l}\text { RA } \\
\text { Swimming }\end{array}$ & & & $-.0290(.0464)$ & & $-.0241(.0470)$ \\
\hline RA_Kayaking & & & $\begin{array}{c}- \\
.2082 * * *(.0352)\end{array}$ & & $\stackrel{-}{-} .2110 * * *(0389)$ \\
\hline
\end{tabular}

Table 4.46 displays the regression output from five models from the hydrological model.

(10) Model 10 displays a robust logit model with the full set of attributes from the hydrological model choice card as well as income and the plan variable, but excluding the "farmland acreage attribute." The "farmland acreage" attribute was highly, positively correlated with the payment variable $(r=0.94)$. As such, including this variable would have created collinear conditions within the model, and therefore, it was subsequently dropped from all of the models. In this model, the payment variable is both negative and significant indicating that as the price of restoration plans increase, the decision to for payment for restoration plans decreases. This outcome is expected in choice experiments. In this model, all variables (Lake Okeechobee, Water Conservation Areas, Everglades 
National Park, Payment, Income, and Plan) except the Restrictions on Water Use attribute are significant at some level. However, the hydrological restoration attributes carry a negative significance direction. However, the constant is also significant, indicating that the model has not captured all the effects on the dependent variable.

(11) Unfortunately, the constant term in Model (11) is also significant, indicating that the additional variables included in this model still did not capture all of the effects on the dependent variable. Model (11) includes all the variables from Model (10) and some key demographic variables such as Age, Gender, YearsResidenceinFl, PoliticalParty, Race, and Education. Again, all the variables from Model (10) with the exception of the Restrictions on Water Use variable are significant at various levels. However, the income variable lost its significance value and the Water Conservation Areas decreased in significance as well. As for the included socio-demographic variables, only Race and PoliticalParty proved to be significant variables; however Race was negatively significant.

(12) Model (12), the final of the robust logit models, did manage to capture the effects on the dependent variable as indicated by a non-significant constant. In this model, the frequency or non-frequency of participation in the various recreational activities (RA) produced significant results. However, Income remains non-significant, and the Everglades National Park variable lost all significance. The Payment attribute is still negatively significant, and the $R A \_$PaddleBoarding and $R A \_$Kayaking proved to be positively significant, while $R A \_$Free Diving aligned as negatively significant. 
(13) Model (13) represents the output from a mixed logit regression, with heterogeneity controlled for at the County level. The Payment attribute is negative and significant and both Lake Okeechobee and the Water Conservation Areas are significant at the highest $\alpha$ levels, along with the other significant demographic variables.

(14) Model (14) represents the output of another mixed logit regression with the full consideration of variables. With the exception of the RA_FreeDiving, all of the corresponding variables in Model (12) maintain their significance.

The following table (Table 4.39) displays the results from Model 15-10 of the species model within the saltwater anglers sample population.

Table 4.39: Regression Output for Species Model- Saltwater Anglers ${ }^{4}$

\begin{tabular}{|c|c|c|c|c|}
\hline \multirow[t]{2}{*}{ Variables } & & Logit Models (Robus & & Mixed Logit \\
\hline & $(15)$ & (16) & $(17)$ & (18) \\
\hline Cons & $-.02306(.48767)$ & $.3578(.6479)$ & $-3.3849 * * *(.8501)$ & $.0322(.5390)$ \\
\hline Wetland Species & $.0051(.0031)$ & $.0058 *(.0058)$ & $.0050(.0035)$ & $.0068 * *(.0033)$ \\
\hline Dryland Species & $.0037(.00565)$ & $.0019(.0058)$ & $.0036(.0062)$ & $.0018(.0059)$ \\
\hline $\begin{array}{l}\text { Florida Bay } \\
\text { Species }\end{array}$ & $.0019(.0053)$ & $.0014(.0054)$ & $.0019(0059)$ & $.0023(.0055)$ \\
\hline $\begin{array}{l}\text { Restrictions on } \\
\text { Water Usage }\end{array}$ & .0673(.2173) & .0499 (.2246) & $-.0607(.2256)$ & $.0841(2314)$ \\
\hline Payment & $\begin{array}{c}-.02086^{* * *} \\
(.0066)\end{array}$ & $-.01999 * * *(.0068)$ & $-.01970 * * *(.0070)$ & $-.0220 * * *(.0071)$ \\
\hline Income & $.0267 *(.0098)$ & $.0178 *(.0107)$ & $.0119(.0113)$ & $.0278^{*}(.0106)$ \\
\hline Plan & $.5509 *(.2147)$ & $.5334 * *(.2185)$ & $.6624 * * *(.2321)$ & $.5366 * *(.2209)$ \\
\hline Age & & $-.0060(.0046)$ & $-.0057(0053)$ & \\
\hline Gender & & $.1262(.1493)$ & $.1786(.1663)$ & \\
\hline Years Residence in & & $.0065 * *(.0032)$ & $.0064 *(.0037)$ & \\
\hline
\end{tabular}

$4 *$ indicates significance at $0.10, * *$ indicates significance at $0.05, * * *$ indicates significance at 0.01 


\begin{tabular}{lcc}
\hline FL & $-.1045^{* * *}(.0284)$ & $-.0882 * * *(.0315)$ \\
Race & $.0365(.0373)$ & $.0070(.0406)$ \\
Education & $-.0664(.0448)$ & $-.0256(.0497)$ \\
Political Party & $.8641^{* * *}(.0763)$ \\
Sure Choice & $-.0651(.0450)$ \\
RA_VisitBeach & $.0151(.0528)$ \\
RA_Fishing & $.0541(.0463)$ \\
RA_Boating & $.1239^{* * *}(.0424)$ \\
RA_ & \\
PaddleBoarding & $.0124(.0452)$ \\
RA_ScubaDiving & $-.0259(.0468)$ \\
RA_FreeDive & $.0685(.0531)$ \\
RA_Snorkeling & $-.0946 * *(.0454)$ \\
RA_Swimming & & $-.1298 * * *(.0335)$ \\
RA_Kayaking & & \\
\hline
\end{tabular}

Table 4.40 display the regression output from four models for the species model within the saltwater anglers sample population.

(15) Model 15 represents a robust logit model the full set of attributes from the species model choice cards, along with the plan and income variable. Once again, the Farmland Acreage attribute was excluded from the all of the models due to the perfectly negative correlation with the payment attribute $(r=-0.100)$. Although all of the attributes were included in Model (15) only the Payment attribute, Income, and the Plan variable were significant influential variables on the dependent variable. The Payment attribute was expectedly negatively significant, and Income was expectedly positively significant. This outcome indicates that as the Payment attribute for restoration plans increase, the decision to pay for these plans decrease. Also, as Income increase, the decision to pay for restoration plans also increase, as people with higher incomes have more ability to pay, ATP.

(16) Model 16 displays the results of another robust logit model, which included the full set of attributes from the species choice card (excluding the Farmland Acreage attribute) 
and key demographic variables. In this model, the Payment attribute, as well as the Income and Plan variable remain significant, but the Wetland Species attribute also is significant at the $0.10 \alpha$ level indicating this attribute has some effect on the dependent variable. As for the demographic variables, Race remained negatively significant (from the hydrological model results). However, for the first time, the YearsResidenceinFl produced a positively significant value, suggesting that increased years of residing in Florida produces a higher likelihood to pay for restoration.

(17) Model 17 depicts the output from the final robust logit model, and includes all the variables from Model (16) in combination with the sure choice variable and the set of frequency of recreational activities. Interestingly, the constant term in Model (17) is highly significant indicating that despite the large amount of independent variables included in the regression, the model has not captured all the effects on the dependent variable. As in Model (15), none of the species restoration attributes are significant, and even income has lost its significance in this model. The Payment, Plan, YearsResidenceinFl, and Race variable remain significant. As for the included recreational activities, both $R A \_$Swimming and $R A \_$Kayaking were negatively significant, and RA_PaddleBoarding was positively significant. As seen in Table 4.35, the categorical indicators 1-7 correspond to decreasing frequencies for recreational activities. Therefore, as the categorical indicators for swimming and kayaking decrease (recreational participation in these activities decrease), the decision to pay for restoration also decreases. With regards to paddle boarding, as frequency in participation declines, the decision to pay for restoration increases. 
(18) Model 4 displays the output of a mixed logit regressions controlling for heterogeneity at the YearsResidenceinFl level. Since this variable was positively significant in Models (16) and (17), I decided it might be prudent to further control for heterogeneity at this level. Model (18) shows a positively significant Wetland Species attribute (as restoration levels increase in this attribute, the decision to pay subsequently increases). As with Model (16), the Payment, Income, and Plan attribute are also significant at the same levels and relationship.

\subsection{Willingness to Pay Values}

The regression analysis provides the foundation for generating $m W T P$ and $W T P$ values for positively, significant restoration plan components that represent ecological or social attributes. The formula for generating mWTP values is shown by Equation (1) in which $\beta c$ represents the coefficient of any of the restoration plan attributes, and $\beta y$ is the coefficient of the cost attribute (Hanley, Mourato, and Wright, 2001). The result from the ratio of the coefficient of the attribute over the coefficient of the price results in the $m W T P$ coefficient. Table 4.40 displays the results of $m W T P$ coefficients for each of the positive and significant attributes within the hydrological and species models.

$$
m \boldsymbol{W T P}=\frac{-\beta c}{\beta y}
$$


Table 4.40: Marginal Willingness to Pay $(m W T P)$ values per Attributes

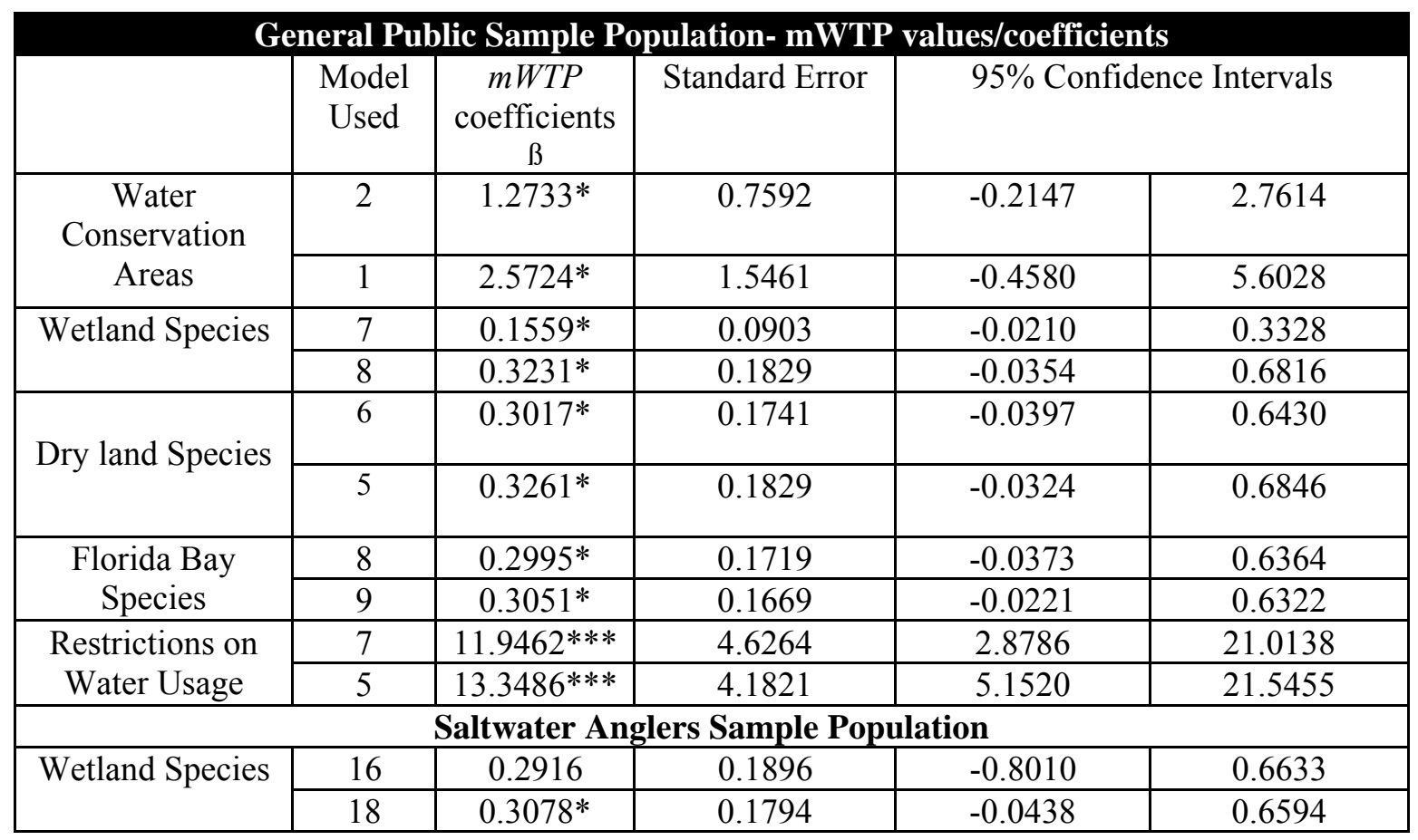

Table 4.41 displays the $W T P$ values of the significant and positive ecological and social attributes within the general public and saltwater anglers sample population. The table contains the $m W T P$, average $W T P$, and the $W T P$ values extrapolated across total households in South Florida and total households across Florida, and total WTP estimates over 10 years.

Table 4.41 Willingness to Pay (WTP) values for Both Sample Populations

\begin{tabular}{|c|c|c|c|c|c|}
\hline \multicolumn{6}{|c|}{ General Public- Willingness to Pay } \\
\hline Attributes & $\bar{B}$ & $m W T P$ & Avg. $W T P$ & $\begin{array}{c}\text { South Fl. Population } \\
\text { WTP } \\
n=2,044,741 \\
\text { households } \\
\end{array}$ & $\begin{array}{c}\text { Fl. Population WTP } \\
\begin{array}{c}n=7,147,013 \\
\text { households }\end{array}\end{array}$ \\
\hline $\begin{array}{c}\text { Water } \\
\text { Conservation } \\
\text { Areas }\end{array}$ & & $\begin{array}{l}\$ 1.27- \\
\$ 2.57\end{array}$ & $\begin{array}{l}\$ 89.66- \\
\$ 160.26\end{array}$ & $\begin{array}{l}\$ 2,596,821.00- \\
\$ 5,254,984.00\end{array}$ & $\begin{array}{l}\$ 9,076,707.00- \\
\$ 18,367,823.00\end{array}$ \\
\hline Wetland Species & & $\begin{array}{l}\$ 0.16- \\
\$ 0.32\end{array}$ & $\begin{array}{l}\$ 8.11- \\
\$ 16.22\end{array}$ & $\begin{array}{c}327,158.60- \\
\$ 654,317.10\end{array}$ & $\begin{array}{r}\$ 1,143,522.00- \\
\$ 2,287,044.00\end{array}$ \\
\hline
\end{tabular}




\begin{tabular}{|c|c|c|c|c|c|}
\hline Dry land Species & & $\begin{array}{l}\$ 0.30- \\
\$ 0.32\end{array}$ & $\begin{array}{l}\$ 18.54- \\
\$ 19.78\end{array}$ & $\begin{array}{l}\$ 613,422.30- \\
\$ 654,317.10\end{array}$ & $\begin{array}{l}\$ 2,144,104.00- \\
\$ 2,287,044.00\end{array}$ \\
\hline $\begin{array}{l}\text { Florida Bay } \\
\text { Species }\end{array}$ & & $\begin{array}{l}\$ 0.30- \\
\$ 0.31\end{array}$ & $\begin{array}{l}\$ 22.47- \\
\$ 23.22\end{array}$ & $\begin{array}{l}\$ 613,422.30- \\
\$ 633,869.70 \\
\end{array}$ & $\begin{array}{l}\$ 2,144,104.00- \\
\$ 2,215,574.00\end{array}$ \\
\hline $\begin{array}{c}\text { Restriction } \\
\text { on Water Usage }\end{array}$ & & $\begin{array}{l}\$ 11.95- \\
\$ 13.35\end{array}$ & $\begin{array}{l}\$ 23.90- \\
\$ 35.85\end{array}$ & $\begin{array}{l}\$ 24,434,655.00 \\
\$ 27,297,292.00\end{array}$ & $\begin{array}{l}\$ 85,406,805.00 \\
\$ 95,412,624.00\end{array}$ \\
\hline & & & & Over 10 Years & Over 10 years \\
\hline $\begin{array}{c}\text { Water } \\
\text { Conservation Areas } \\
\end{array}$ & & & & $\begin{array}{l}\$ 25,968,210.00- \\
\$ 52,549,840.00 \\
\end{array}$ & $\begin{array}{l}\$ 90,767,070.00- \\
\$ 183,678,230.00\end{array}$ \\
\hline Wetland Species & & & & $\begin{array}{l}\$ 3,271,586.00- \\
\$ 6,543,171.00\end{array}$ & $\begin{array}{r}\$ 11,435,220.00- \\
\$ 22,870,440.00\end{array}$ \\
\hline Dry land Species & & & & $\begin{array}{l}\$ 6,134,223.00- \\
\$ 6,543,171.00\end{array}$ & $\begin{array}{l}\$ 21,441,040.00- \\
\$ 22,870,440.00\end{array}$ \\
\hline $\begin{array}{l}\text { Florida Bay } \\
\text { Species }\end{array}$ & & & & $\begin{array}{l}\$ 6,134,223.00- \\
\$ 6,338,697.00\end{array}$ & $\begin{array}{l}\$ 21,441,040.00- \\
\$ 22,155,740.00\end{array}$ \\
\hline $\begin{array}{c}\text { Restriction } \\
\text { on Water Usage } \\
\end{array}$ & & & & $\begin{array}{l}\$ 244,346,550.00 \\
\$ 272,972,920.00 \\
\end{array}$ & $\begin{array}{l}\$ 854,068,050.00 \\
\$ 954,126,240.00 \\
\end{array}$ \\
\hline \multicolumn{6}{|c|}{ Saltwater Anglers- Willingness to Pay } \\
\hline & & & & \multicolumn{2}{|c|}{$\begin{array}{c}\text { Current and Active } \\
\text { Fishing Licenses Population WTP } \\
n=1,235,381\end{array}$} \\
\hline \multirow[t]{2}{*}{ Wetland Species } & $\begin{array}{l}0.0058 \\
0.0068\end{array}$ & $\begin{array}{l}\$ 0.29- \\
\$ 0.31\end{array}$ & $\begin{array}{l}\$ 15.05- \\
\$ 16.10\end{array}$ & \multicolumn{2}{|c|}{$\begin{array}{c}\$ 358,260.50- \\
\$ 382,968.11\end{array}$} \\
\hline & & & & \multicolumn{2}{|c|}{ Over 10 years } \\
\hline Wetland Species & & & & \multicolumn{2}{|c|}{$\begin{array}{l}\$ 3,582,605.00- \\
\$ 3,829,681.10\end{array}$} \\
\hline
\end{tabular}

In the general public, the only positive and significant restoration attribute in the hydrological model was the "Water Conservation Areas" and within the species model all included attributes within the regression exhibited significance within 2 or more models. Note, the Farmland Acreage attribute was not included within any of the models due to collinearity with the payment variable, and therefore no estimated $W T P$ values could be produced for this attribute. In the saltwater anglers sample population, only the Wetland Species attribute exhibited statistical significance. Based on Equation (1), I determined a range that included both the minimum and maximum $m W T P$ values and 
extrapolated these values across the total number of households in South Florida and Florida for each attribute. The average $W T P$ represents the $m W T P$ for each attribute multiplied by the mean value of each attribute, respectively. Overall, respondents in the general public were willing to pay a reasonable amount, $\$ 1.27-\$ 2.57$ for each unit, or percentage point increase of hydrological restoration within the Water Conservation Areas. When extrapolated to represent the 2,044,741 households within South Florida, this range increases to $\$ 2,596,821.00$ - $\$ 5,254,984.00$ annually. If extrapolated to include the total amount of households within the state of Florida $(n=7,147,013)$, the range increases to $\$ 9,076,707.00$ - $18,367,823.00$ annually. Since the willingness to pay for restoration scenarios were framed to include payments for restoration over 10 years, when extrapolated over these 10 years, the total range of WTP for hydrological restoration within the Water Conservation Areas increases to \$29,968,210.00$\$ 52,549,840.00$ within South Floridian households and $\$ 90,767,070.00-\$ 183,678,230.00$ dollars for the total amount of households in the state of Florida.

Within the species model, the wetland species attribute proved to be significant in both the general public and saltwater anglers sample population. Respondents in the general public indicated they would be willing to pay within a slightly lower range per unit, or percentage point increase of restoration for the wetland species population with a $m W T P$ range of $\$ 0.16-\$ 0.32$ per household annually. In the saltwater anglers sample, the $m W T P$ for the restoration of the wetland species population amounted to $\$ 0.29-\$ 0.31$ per household annually. When this range is extrapolated within the general public to included the total number of households in South Florida, the figure increases to $\$ 327,158.60$ $\$ 654,317.10$, annually and $\$ 3.27$ - $\$ 6.54$ million over 10 years. In the saltwater anglers 
sample population, the figures were slightly less grand, since the population size of current and active saltwater fishing licenses holders in Florida equates to $1,235,381$ people. Overall, the $m W T P$ range per individual annually was close, yet more narrow than the general public amount at $\$ 0.29-\$ 0.31$. When this amount is extended to include the total population of saltwater anglers, the range of WTP increase to $\$ 358,260.50$ $\$ 382,968.11$, annually and $\$ 3.58$ to $\$ 3.83$ million over 10 years.

As for the dry land species, only the general public respondents were willing to pay for their species population restoration within a small $m W T P$ range of $\$ 0.30$ - $\$ 0.32$ per percentage point increase of species restoration. When extrapolated to the South Florida population, this figure becomes $\$ 613,422.30$ - $\$ 654,317.10$ annually, and $\$ 6.13$ $\$ 6.54$ million over 10 years. When considering the total amount of households within Florida, this figure increases to $\$ 2.14$ - \$2.29 million annually, and \$21.4- \$22.9 million over 10 years.

With regards to the Florida Bay species, respondents in the general public indicated they were willing to pay for increasing percentage points of restoration for this species group within a very small $m W T P$ range of $\$ 0.30$ - $\$ 0.31$. This $m W T P$ range produced an annual WTP range within South Floridian households of $\$ 613,422.30$ $\$ 654,317.70$ and $\$ 6.13$ - $\$ 6.34$ million over 10 years. When the $m W T P$ per unit increase of Florida Bay species restoration is extrapolated over the total amount of households in Florida, the range for annual WTP is increased to \$2.14- \$2.21, and \$21.4- \$22.1 million over 10 years.

Finally, respondents in the general public expressed their WTP for restrictions on water usage within the species model at a $m W T P$ range of $\$ 11.95$ - $\$ 13.35$ per unit to 
avoid restrictions on indoor and outdoor household use of water. When extrapolated to the total number of households in South Florida, the WTP range generated is \$24.4- \$27.3 million annually and \$85.4- \$95.4 million annually across total households in Florida. However, when this range is extended over 10 years, the resulting range is $\$ 244.3$ \$272.9 million for total households in South Florida and \$854.1- \$954.1 million for total households in the state of Florida. 


\section{CHAPTER 5: DISCUSSION}

\subsection{Discussion}

5.1.1 Willingness to Pay Values for Ecological and Social Attributes

\subsubsection{Water Conservation Areas - Hydrological Model}

Within the general public sample, only the Water Conservation Areas from the hydrological model generated $W T P$ values. This hydrological feature elicited the $2^{\text {nd }}$ highest WTP range for restoration of all the attributes, or to $\$ 2.6$ - $\$ 5.25$ million annually in South Florida and $\$ 9.08$ - \$18.4 million annually in across households in Florida, with a $m W T P$ range of $\$ 1.27-\$ 2.57$. This finding is relatively small when compared to the $m W T P$ value produced for this same attribute in the Milon et al. (1999), or $\$ 17.63$. This feature actually produced the highest $m W T P$ value in the Milon et al. (1999) study, which attributed this value to higher utility values gained from increases of restoration within this area. Therefore, in spite of Lake Okeechobee and the Everglades National Park not producing any statistically significant effects, it seems fitting that at the very least the Water Conservation Areas did produce both a positive, significant effect and $W T P$ values.

\subsubsection{Wetland, Dryland, and Florida Bay Species- Species Model WTP}

As indicated in Table 4.41, the $m W T P$ range per household for wetland species restoration amounted to $\$ 0.16$ - $\$ 0.31$ within the general public sample population, and \$0.29- \$0.31 in the saltwater anglers sample population. These ranges are comparatively less than the $m W T P$ ranges developed within the Milon et al. (1999) study, which produced a $m W T P$ value of $\$ 9.26$. However, in the Milon et al. (1999) study, the wetland

species produced the $2^{\text {nd }}$ highest of the $m W T P$ values within the species model. The dry 
land species produced a negative $W T P$ value of $-\$ 29.87$, while the Florida Bay species (or Estuarine in the original study) generated the highest WTP at \$27.34 per unit increase of species restoration. Based on these WTP values, Milon et al. (1999) concluded that respondents placed a higher premium on the restoration of the habitats for wetland species, such as wading birds, and estuarine species within Florida Bay. The $m W T P$ ranges produced this study were $\$ 0.30$ - $\$ 0.32$ for the dry land species and $\$ 0.30$ - $\$ 0.31$ for the Florida Bay species. The ranges for both of these species population were narrower and much smaller in terms of minimum and maximum $m W T P$. Nevertheless, the respondents in the general public sample did express their preference for improved habitats for all types of species, while the saltwater anglers sample population only expressed interest in improving the wetland species.

\subsubsection{Restrictions on Water Usage}

Within the general public, the Restrictions on Water Usage produced the highest $m W T P$ range of $\$ 11.95$ - $\$ 13.35$ per household annually per unit to avoid restrictions on household water use. When extrapolated to include the total households in Florida and payment over 10 years produced a $W T P$ range of $\$ 854.1$ - $\$ 954.1$ million. This range is much less than the amount produced by the Milon et al. (1999) study of up to $\$ 3.42$ $\$ 4.07$ for full restoration over a 10 year period. However, the WTP range developed within this study was solely for the purpose of avoiding restrictions on water usage, and not for payment of hydrological restoration within the Everglades. According to Miami Dade Water And Sewer Department, or WASD (2013), the average single-family 
residential monthly water bill equates to $\$ 45.30$, or $\$ 544.68$ annually for 6,780 gallons of water per month, or 81,360 gallons a year for both indoor and outdoor water use.

When considering the attribute levels within the restrictions on water usage, each marginal increase in payment for avoidance of water restrictions results in paying for an additional day of outdoor water use and $15 \%$ more indoor water consumption. Table 5.1 represents the breakdown of how the levels within the restrictions on water usage apply to the average single-family residential monthly water consumption. Note: the average single-family monthly water consumption includes BOTH indoor and outdoor water consumption- WASD cannot track water usage once the water passes through the water meter and into the property.

Table 5.1: Application of Water Use Restrictions to Average Single Family Residential Monthly Water Consumption (Gallons)

\begin{tabular}{lcc|}
\hline Levels of Restrictions of Water Usage & $\begin{array}{c}\text { Amount of Gallons } \\
\text { Reduced }\end{array}$ & $\begin{array}{c}\text { Approximate Gallons } \\
\text { for use }\end{array}$ \\
\hline $\begin{array}{l}\text { 1 day per week of outdoor use/ 40\% } \\
\text { indoor reduction }\end{array}$ & $-2,712$ gallons & 4,068 total gallons \\
$\begin{array}{l}\text { 2 days per week of outdoor restrictions/ } \\
\text { 25\% indoor reduction } \\
\text { 3 days per week of outdoor use/ 10\% } \\
\text { indoor reduction }\end{array}$ & $-1,695$ gallons & 5,085 total gallons \\
\hline
\end{tabular}

In Table 5.1, the approximate gallons for use represents how the average water consumption of a single family decreases with the respective restriction of water usage applied to each situation. However, since the baseline water consumption used in these calculations does not distinguish between indoor and outdoor water use, these estimates should only be used to approximate the effect of the water restrictions on household 
consumption. When considering these estimations, recall the $m W T P$ range generated in aversion to these restrictions amounted to $\$ 11.95$ - $\$ 13.35$. WASD in Miami-Dade County estimates the average water bill at $\$ 45.39$ monthly, for which paying an extra $\$ 11.95$ $\$ 13.35$ to increase indoor water consumption by $15 \%$ and outdoor use of water by an extra day seems like a reasonable amount of expenditure. In terms of annual costs to the average household, paying $\$ 11.95$ - $\$ 13.35$ in extra costs to avoid water restrictions represents an approximately $2.15 \%-2.4 \%$ increase when added to the average annual water bill, $\$ 554.68$.

As previously stated, only the Water Conservation Areas attribute elicited WTP values, and to some extent this outcome may have been prompted in lieu of preserving the recreational values of this area, and not for increased hydrological flow within the Everglades. Within the saltwater anglers sample population, support for Restrictions on Water Use social attribute in either of the choice models were non-existent, as was support for any of the hydrological attributes. Yet, respondents were more willing to pay to avoid restrictions on their indoor and outdoor water consumption. However, in order to avoid these water usage restrictions, some level of hydrological restoration within the Everglades must be accomplished in order to increase the amount of water within the system. As such, there exists a large disconnect between what respondents want to maintain social conveniences and how to achieve these goals through ecological restoration. While the respondents are willing to pay a substantial amount of money to avoid restrictions, they seem to be unaware of the process, or hydrological restoration, needed to avoid these restrictions. This observation suggests that respondents are more concerned and prompted to pay for the outcome, and not the process. 


\subsubsection{Comparison of Current Study Results and Milon et al. (1999)}

The results from the current study differ tremendously from the results of Milon et al. (1999). Overall, WTP values seem to have decreased across the board when compared to the values produced 15 years ago, and the direction of the co-efficients of certain attributes have also seemed to negate themselves over time. The results from the hydrological model regression analysis within the saltwater anglers sample population, displayed in Table 4.38, produced significant, yet negative coefficients on certain attributes, for which negative willingness to pay values could be generated. In this table, Lake Okeechobee, the Water Conservation Areas, and the Everglades National Park, in some instances, produced negatively, significant coefficients. This observed outcome suggests that as restoration levels increased within the choice cards, willingness to pay decreased. Albeit, the results from Milon et al. (1999) does not consider a specific stakeholder group like the licensed saltwater angler in Florida, predictably one could argue that this specialized population would have more of an incentive to support restoration efforts. As for the general public negative $W T P$ values were not observed within this sample population. However, the Lake Okeechobee and Everglades National Park hydrological restoration attributes generally maintained a negative direction even though the attributes were not significant, suggesting they had no effect on the decision to pay. The observed negative effect on the decision to pay for restoration is especially interesting when comparing the results from Milon and Scrogin (2006), which displays the results from four different models for which these attributes are positively significant indicators on the dependent variable. The following table, Table 5.2, displays a 
comparison between the co-efficients for the hydrological and species model developed within the Milon et al. (199) study and the current, along with any respective $m W T P$ values.

Table 5.2 Hydrological and Species Co-efficient and $m W T P$ Comparison between Milon et al. (1999) and the Current Study

\begin{tabular}{|c|c|c|c|c|}
\hline & \multicolumn{2}{|c|}{ Milon et al. (1999) Results } & \multicolumn{2}{|c|}{ General Public- Current Study Results } \\
\hline Attributes & $\begin{array}{c}\text { Coefficient/ } \\
\text { Standard Error }\end{array}$ & $\begin{array}{l}\text { Marginal } \\
\text { WTP }\end{array}$ & $\begin{array}{c}\text { Coefficient/ Standard } \\
\text { Error }\end{array}$ & $\begin{array}{l}\text { Marginal } \\
\text { WTP }\end{array}$ \\
\hline Lake Okeechobee & $\begin{array}{l}0.7876^{*} \\
(0.3675)\end{array}$ & $\$ 9.68$ & - & - \\
\hline Water Conservation Areas & $\begin{array}{l}0.8606^{*} \\
(0.2666)\end{array}$ & $\$ 17.63$ & $\begin{array}{c}.0082 * * *(.0022) \\
-.0065^{* * *}(.0025)\end{array}$ & $\begin{array}{l}\$ 1.27- \\
\$ 2.57\end{array}$ \\
\hline Everglades National Park & $\begin{array}{c}0.3419 \\
(0.3310)\end{array}$ & $\$ 7.01$ & - & - \\
\hline $\begin{array}{l}\text { Restrictions on Water Use } \\
\text { (Hydro) }\end{array}$ & $\begin{array}{c}-0.0220 \\
(0.1063) \\
-0.4539^{*} \\
(0.0973)\end{array}$ & $\begin{array}{c}-\$ 1.80 \\
-\$ 37.10\end{array}$ & - & - \\
\hline Cost (Hydro) & $\begin{array}{l}-0.0122 * \\
(0.0029)\end{array}$ & - & $\begin{array}{l}-.0032 *(.0019) \\
-.0051 * *(.0023)\end{array}$ & - \\
\hline Wetland Species & $\begin{array}{l}0.5991^{*} \\
(0.1780)\end{array}$ & $\$ 9.26$ & $\begin{array}{l}.0033 *(.0019) \\
.0039 * *(.0019)\end{array}$ & $\begin{array}{l}\$ 0.16- \\
\$ 0.32\end{array}$ \\
\hline Dry Land Species & $\begin{array}{r}-1.1593 * \\
(0.6154)\end{array}$ & $-\$ 29.87$ & $\begin{array}{l}.0058 *(.0033) \\
.0064 *(.0038)\end{array}$ & $\begin{array}{l}\$ 0.30- \\
\$ 0.32\end{array}$ \\
\hline Florida Bay Species & $\begin{array}{l}1.0606^{*} \\
(0.3518)\end{array}$ & $\$ 27.34$ & $\begin{array}{l}.0061 *(.0034) \\
.0066 *(.0035)\end{array}$ & $\begin{array}{l}\$ 0.30- \\
\$ 0.31\end{array}$ \\
\hline $\begin{array}{l}\text { Restrictions on Water Use } \\
\text { (Species) }\end{array}$ & $\begin{array}{c}-0.0869 \\
(0.1027) \\
-0.3391 * \\
(0.0934)\end{array}$ & $\begin{array}{c}-\$ 8.95 \\
-\$ 34.96\end{array}$ & $\begin{array}{l}.22851 * *(.1368) \\
.2120 *(.1196)\end{array}$ & $\begin{array}{l}\$ 11.95- \\
\$ 13.35\end{array}$ \\
\hline Cost (Species) & $\begin{array}{l}-0.0097 * \\
(0.0027)\end{array}$ & - & $\begin{array}{l}(5)-.0177 * * *(.0037) \\
(6)-.0211 * * *(.0041) \\
(7)-.0214 * * *(.0042) \\
(8)-.0205 * * *(.0043) \\
(9)-.0218 * * *(.0044)\end{array}$ & - \\
\hline
\end{tabular}

\subsubsection{Partial and Full Restoration- Current Study v. Milon et al. (1999)}

The Milon et al. (1999) study computed $W T P$ values for both partial and full restoration. Partial restoration values represent the individual $W T P$ values for the hydrological or species model attributes, while full restoration represents an aggregate of 
all the partial restoration values. Table 5.3 and 5.4 represents some of the WTP values for partial and full restoration within both models produced in a later publication based on the Milon et al. (1999) study (Milon and Scrogin, 2005). The full restoration values represent the WTP values of both significant and insignificant attributes. The values produced in the current study only represent WTP values from significant attributes. However, in order to compare with Milon et al. (1999), values for insignificant attributes needed to be computed. Table 5.5 represents WTP values for partial and full restoration for significant and insignificant hydrological and species model attributes within the current study for two models. The computation of the insignificant attributes made little differences in the overall full restoration WTP values, especially within the hydrological model where many attributes elicited negative WTP values. Yet, it is important to note the methodological difference in the computation of total WTP in both studies

Table 5.3: WTP values for Hydrological Partial and Full Restoration from Milon and Scrogin (2005)

Willingness to pay for Everglades restoration from the functional attributes subsample

\begin{tabular}{lrrll}
\hline Ecosystem change & MNL & \multicolumn{2}{l}{ Groups } & \\
\cline { 3 - 5 } & & Group 1 & Group 2 & Group 3 \\
\hline $\begin{array}{l}\text { Partial Restoration } \\
\quad \text { Everglades National }\end{array}$ & $\$ 7.95$ & $\$ 51.45$ & - & $-\$ 6.46$ \\
$\quad \begin{array}{l}\text { Park } \\
\text { Water Conservation }\end{array}$ & $\$ 17.48$ & $\$ 54.80$ & - & $-\$ 3.00$ \\
$\quad$ Areas & & & & \\
$\quad$ Lake Okeechobee & $\$ 3.90$ & $\$ 12.60$ & - & $-\$ 7.12$ \\
Full Restoration & $\$ 29.33$ & $\$ 195.27$ & - & $-\$ 29.37$ \\
\hline
\end{tabular}


Table 5.4: WTP values for Species Partial and Full Restoration from Milon and Scrogin (2005)

Willingness to pay for Everglades restoration from the structural attributes subsample

\begin{tabular}{lrrlr}
\hline Ecosystem change & MNL & \multicolumn{2}{l}{ Groups } & \\
\cline { 3 - 5 } & & Group 1 & Group 2 & Group 3 \\
\hline Partial Restoration & & & & \\
$\quad$ Wetland Species & $\$ 29.03$ & $-\$ 8.51$ & - & $\$ 43.67$ \\
Dryland Species & $-\$ 17.37$ & $-\$ 6.28$ & - & $\$ 17.56$ \\
$\quad$ Estuarine Species & $\$ 17.98$ & $-\$ 5.32$ & - & $\$ 32.00$ \\
Full Restoration & $\$ 59.26$ & $-\$ 40.23$ & - & $\$ 186.44$ \\
\hline
\end{tabular}

Table 5.5 WTP values for Partial and Full Restoration in Current Study ${ }^{5}$

\begin{tabular}{|c|c|c|}
\hline Restoration Attributes & Model (3) & Model (5) \\
\hline Partial Restoration & $-\$ 0.50$ & \\
\hline Lake Okeechobee & $\$ 1.42$ & \\
\hline $\begin{array}{c}\text { Water Conservation } \\
\text { Areas*** }\end{array}$ & $-\$ 0.59$ & \\
\hline Everglades National Park & $-\$ 22.24$ & \\
\hline $\begin{array}{c}\text { Restrictions on Water } \\
\text { Usage (Hydro) }\end{array}$ & N/A & $\$ 0.29$ \\
\hline Full Restoration & & $\$ 0.33$ \\
\hline Wetland Species*** & & $\$ 0.23$ \\
\hline Dryland Species* & & $\$ 11.95$ \\
\hline Florida Bay Species & & $\$ 12.80$ \\
\hline $\begin{array}{c}\text { Restrictions on Water* } \\
\text { Usage (Species) }\end{array}$ & & \\
\hline Full Restoration & & \\
\hline
\end{tabular}

$55 *$ indicates significance at $0.10, * *$ indicates significance at $0.05, * * *$ indicates significance at 0.01 


\subsubsection{Lower Willingness to Pay Values}

As previously stated, 15 years have elapsed since the Milon et al. (1999) report was published, and even more years since the study was first initiated. In that time, the political and social climate within the state has changed dramatically. In 2000, the population of Florida was an estimated 15,982,824 people and by 2013 the population rose about $22.33 \%$ to an estimated 19,552,860 people (OEDR 2007; U.S. Department of Commerce 2012). These demographic changes coupled with political changes that favor conservative policies pose an explanation in the observed changes seen in this survey. The recent movement for less government and less taxation poses a fundamental threat to government policies to protect and restore public goods. Government intervention is necessitated when public interests, like the Everglades are at stake. However, if the people are opposed to intervention, these programs may have a difficult time garnering support for their implementation. The results from the study support this conclusion, as respondents in the general public were willing to pay to avoid restrictions on their water usage, but not for restoration. Though these goals are inherently bound together, the public is unaware of this inherent connection and seeks to hinder government intervention on the behalf of environmental protection, while not realizing that this intervention is prompted in the best interests of the public.

Furthermore, the sample size of the current study $(n=2,032$ - general public and $n=873$ - saltwater anglers) totals 2,905 households sampled for this study, which vastly exceeds the 480 households included in the Milon et al. (1999) study. The general public sample of 2,032 is most comparable with the sample population ascertained in the Milon 
et al. study (1999), which targeted households within the Miami, West Palm Beach, Fort Myers, Tampa and Orlando metropolitan areas. The current study displays the results from a more geographically representative population within Florida. Out of the 67 counties within Florida, only six counties were not represented within the general public sample population, including Glades County, Hardee County, Lafayette County, Liberty County, Suwannee County, and Union County. All of these counties maintain populations under 45,000 people, which may have lead to the smaller probability of our sampling methods reaching residents in these counties. All other 61 counties were represented in this study by at least 1 respondent. The top five counties represented in the general public sample of the current study includes Miami- Dade (13.8\%), Broward (13.4\%), Palm Beach (9.5\%), Pinellas (5.6\%), and Orange County (5.3\%). Although the Milon et al. (1999) study targeted their respondents from specific areas in the above listed counties, the increased representation in the current study likely paints a more accurate portrayal of statewide preferences for Everglades's restoration. Therefore, the lower WTP ranges resulting across the board may be attributed to higher statewide representation within this study.

\subsubsection{Hypothesis Testing}

With regards to the hypotheses developed for this study, Hypothesis (2) should be voided due to incomplete data and the inability to run the analysis needed to determine the results of these tests. Therefore, only Hypothesis (1) can be assessed.

$\mathrm{H} 0: m W T P W e t l a n d S p e c i e s=m W T P F l o r i d a B a y$ Species $=m$ WTPDrylandSpecies $\mathrm{H}_{1}: m W T P$ WetlandSpecies $\neq m$ WTPFloridaBaySpecies $\neq m$ WTPDrylandSpecies 
As the results in Table 4.40 show, we reject the null hypothesis as the $m W T P$ of all of these attributes differ. I formulated this hypothesis with consideration to the Milon et al. (1999) conclusion that the restoration of the wetland and Florida Bay (estuarine) species garnered higher preferences when compared to the dry land species, which produced negative WTP. This outcome did not extend into the current study, in which all species population groups produced positive $W T P$ values within the general public.

\subsubsection{External Validation of Results}

In the recent 2014 Midterm elections, Florida voters casted their vote on a state constitutional amendment, known as Amendment One, or the Water and Land Conservation Amendment. According to the ballot summary, Amendment One seeks to:

"Fund(s) the Land Acquisition Trust Fund to acquire, restore, improve, and manage conservation lands including wetlands and forests; fish and wildlife habitat; lands protecting water resources and drinking water sources, including the Everglades, and the water quality of rivers, lakes, and streams; beaches and shores; outdoor recreational lands; working farms and ranches; and historic or geologic sites, by dedicating 33 percent of net revenues from the existing excise tax on documents for 20 years "(Florida Department of State: Division of Elections, 2014).

Essentially the amendment seeks to amend the Florida State Constitution to ensure that $33 \%$ of the Documentary Stamp Tax would be allocated to protect water resources and preserved Florida's natural resources. The amendment only required a $60 \%$ majority for 
approval, and received a 74.96\% $(4,238,739$ million votes) majority (Florida Division of Elections, 2014). The overwhelming support for this amendment stands validated by the current study. Recall Table 4.3 in which the choice selection frequency for the hydrological model within the general public sample is displayed. The table indicates that $76 \%$ (a combined $45.8 \%$ and $30.2 \%$, respectively) of respondents favored either a 100,000 or 200,000 reduction in farmland acreage in order to sustain hydrological restoration. The $76 \%$ of respondents who preferred this reduction reflects very closely the number of voters, $74.96 \%$, who voted to enact Amendment One. Therefore, the results from the 2014 November election externally validate a key finding. As the hydrological restoration of Everglades calls for the reduction of farmland to accommodate the increase in water flow, and Amendment One appropriates funds for such action when deemed necessary, the similarity in percentage of support for both initiatives solidifies public support for conservation and restoration efforts. However, it should be noted voters were willing to vote for this amendment when its implementation would not pose an additional cost to taxpayers, but instead from an existing tax.

\subsubsection{Cognitive Dissonance}

The negative $W T P$ values observed in the saltwater angler sample for hydrological restoration and the WTP values generated in order to avoid restrictions on water usage within the general public sample imply a central finding that is key to understanding the results displayed within this study: a high level of cognitive dissonance exists between people's understanding of the environment's benefits towards society, and how they act to improve maximize the benefits they receive from the environment. The 
theory of cognitive dissonance states, "dissonance is a psychological state of tension that people are motivated to reduce" (Shultz and Lepper, 1999, pg. 219). In this study, people seem to understand that the environmental priorities are paramount goals for shaping public policy. Recall Figure 4.3 (shown below), in which respondents in both sample populations were asked to indicate their priorities for public policy, when asked to choose between protecting the environment and economic growth. Overwhelmingly, respondents in both sample populations indicated they preferred environmental priorities over economic growth, as the majority of responses, $61.2 \%$ in the general public and $74.8 \%$ in the saltwater anglers, fell within the 1-3 range. Yet, if respondents expressed such a high level of favorability for environmental polices, how did this not translate into WTP for hydrological restoration?

When specifically looking at the saltwater anglers sample, all evidence within the primary analysis (higher favorability of Plan B within hydrological and species choice cards, preferences for $\$ 70$ payment options) would lead to the conclusion that respondents especially in this sample would pay for restoration. However, this conclusion was not supported by the regression analysis. This disconnect is evidenced by the fact that the only ecological restoration attribute in which respondents in both sample populations expressed they were willing to pay for was the wetland species attribute. As explained in the previous section, negative and significant coefficients were observed within the saltwater angler sample for hydrological restoration attributes. Again, these same attributes were not significant in any direction in the general public sample, with the exception of the Water Conservation Areas. Moreover, the social attribute 


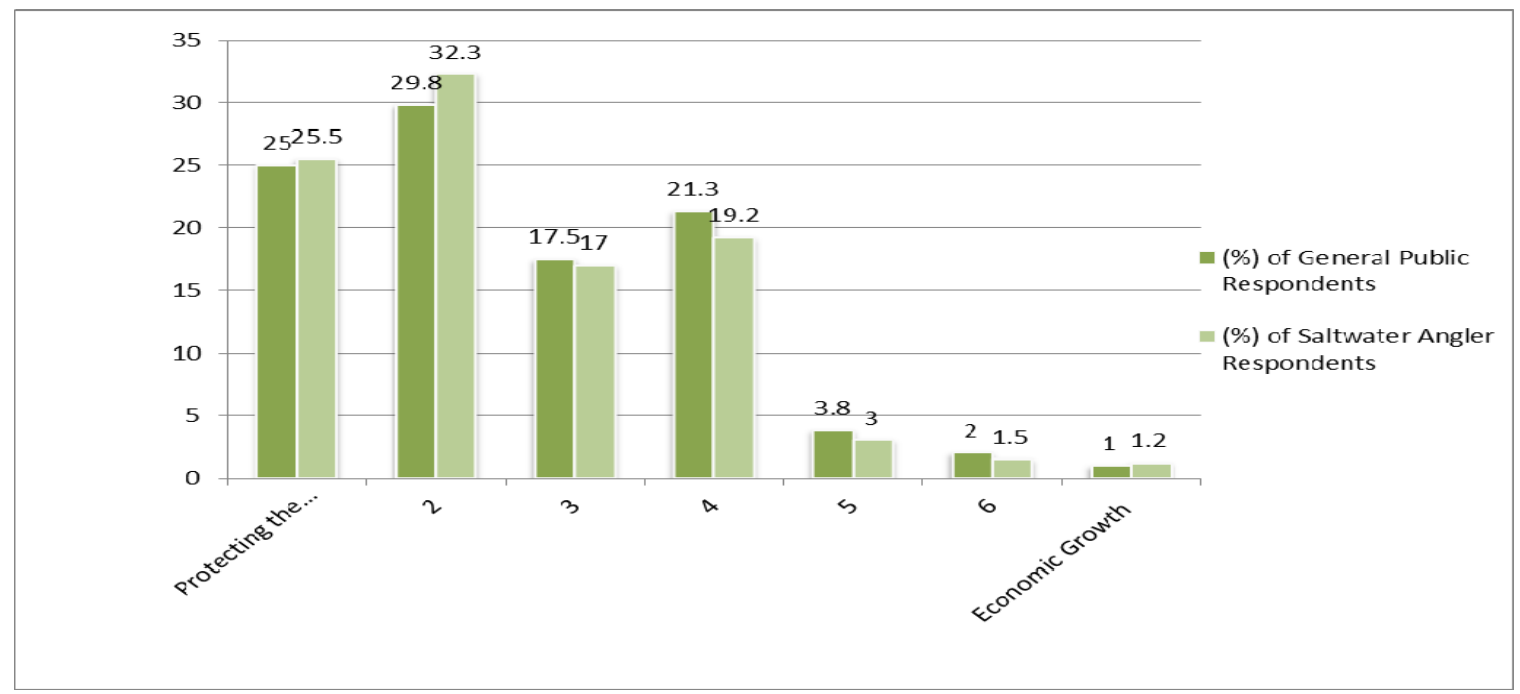

of Restrictions on Water Usage within the species model produced the highest WTP values amongst all the attributes. While respondents may express favorability for protecting of the environment, they do not seem willing to pay for this protection unless this outcome is framed within a social benefit, i.e. avoidance of water restrictions.

\subsubsection{Policy Recommendations}

The lack of $W T P$ for certain elements of the hydrological restoration of the Everglades coupled with the large $W T P$ ranges generated for avoidance on restrictions on water usage prefaces a significant conclusion for policy formation. The public at large is highly disconnected with the realities of where basic resources stem from. In order to avoid restrictions on water usage, some extent of the planned restoration of the Everglades must occur. The preference for paying to avoid water restrictions indirectly pays for restoration of the Everglades, which pays for unintended benefits to society, such as increases in various species populations and the conversion of farmland to accommodate the extra flow of water throughout the system. This dynamic signals that the public is more interested in the end result (increased water supply) than the 
ecological process that delivers this result (hydrological restoration). This conclusion may hold the key in generating support for environmental policies or programs: frame the message to emphasize the benefits society receives from the ecological process. While this method may seem highly anthropocentric as it highlights society's more narcissistic tendencies, this re-framing will inherently achieve the same goals stemming from a purely moral argument for environmental preservation or restoration. Theoretically, we would like to believe that as a society, our sole motivation for public policy preferences does not only consider economic outcomes. Pragmatically, we have limited resources in funding public policy and we must allocate these resources rationally to maximize future benefits. Funding for restoration of the Everglades provides these forms of long-term benefits- yet, respondents were disinclined to acquiesce to restoration because they could not contextualize how restoration would benefit them. By re-framing the message to include how restoration will improve their day-to day life in the future, we can garner more support for environmental programs.

\subsection{Concluding Remarks}

Entrenched in our political and economic dogma lies a fundamental mistruth about the relationship between the environment and the economy. This mistruth compels further misunderstanding about the complexity of our economic embedment within the environment, which breads resistance towards environmental regulations. For example, demagogues will consistently echo a scenario in which the enforcement of an environmental regulation may save $x$ amount of trees and subsequently result in the loss of $y$ amount of jobs. Although this scenario hints at this relationship, it inevitability 
mischaracterizes the inherent connection. The demagogues fail to emphasize that without the existence of those trees, the jobs stemming from the production or utilization of trees would cease to exist in the first place. This example can be substituted for innumerable resources and consistent detrimental economic outcomes. Yet, all of these examples are ill conceived and contrived in terms of advancing the idea that economy depends on scarce, natural resources. The ecosystems in compilation with earth systems provide the natural infrastructure for economic growth, in an almost parasitic relationship. Without the resources bestowed by the Earth, man could not develop a goods and services based economy let alone a functional society. As such, environmental regulations seek to safeguard against short-term economic gains in favor of sustainability and the extension of benefits beyond a single decision maker.

Furthermore, the resources provided by ecosystem serve a higher purpose than simply providing raw materials for economic production. They function as an integral, living organism regulating natural processes that are critical for our survival as well as the survival of all other biota. These ecosystems are responsible for atmospheric regulation, nutrient cycling, pollination for crops and other plant life and much more. Ecosystems provision, regulate, support and inspire life on Earth. Their intrinsic value likely supersedes any estimate of economic value generated. Yet, we must continue to develop these estimates of worth even if underestimated. Our data driven, quantitatively minded society must have a way of understanding value in familiar terms. Economic values of environmental goods and services derived from the utility functions of the public deliver this familiarity. As economic estimates of worth of environmental 
resources informs people and decision makers alike, one can only hope that these estimates motivate both parties in taking action to preserve these resources.

Economic estimates of environmental goods and services have the ability to provide the impetus for action, by dispelling the widely held belief that conservation or preservation of environmental resources is in opposition with economic objectives. Informing the public and regional decision makers of the potential economic value of environmental goods and services will hopefully spur the political will for preservation of resources. The protection and restoration of public goods requires immediate attention in light of the rate of climate change. Global climate change is poised to further undermine the essential environmental dynamics needed for economic growth, thereby compromising our economic security. In fact, the advent of civilization and the rapid industrial growth over the last 170 years were all predicated on the stability of a global climate that facilitated this miracle of human advancement. If we hope to continue this advancement, we must formulate multi-faceted solutions and summon the political will to alleviate the pressures on our rapidly destabilizing global climate system. In order to do so, we must first recognize the substantial value our ecosystems play in provisioning life on Earth, and how impossible our lives would be without their vigilant continuity of services. 


\section{REFERENCES}

Adamowicz, W., Boxall, P., Williams, M., \& Louviere, J. (1998). Stated preference approaches for measuring passive use values: choice experiments and contingent valuation. American journal of agricultural economics, 80(1), 64-75.

Audobon Florida. (2012). 2012 Wading Bird Nesting in the Everglades. Retrieved from Audobon Florida website:

http://fl.audubon.org/sites/default/files/documents/audubon_everglades_wadingbirds_jan 2013.pdf

Alongi, D. M. (2008). Mangrove forests: resilience, protection from tsunamis, and responses to global climate change. Estuarine, Coastal and Shelf Science, 76(1), 1-13.

Awual, M. R., Jyo, A., Ihara, T., Seko, N., Tamada, M., \& Lim, K. T. (2011). Enhanced trace phosphate removal from water by zirconium (IV) loaded fibrous adsorbent. Water research, 45(15), 4592-4600.

Barbier, E. B., Hacker, S. D., Kennedy, C., Koch, E. W., Stier, A. C., \& Silliman, B. R. (2011). The value of estuarine and coastal ecosystem services. Ecological Monographs, 81(2), 169-193.

Barnes, T. (2005). Caloosahatchee Estuary conceptual ecological model. Wetlands, 25(4), 884-897.

Bell, F. W. 1987. The economic impact and valuation of the recreational and commercial fishing industries of Lake Okeechobee, Florida. Fla. Game and Fresh Water FishComm., Tallahassee, Fla. 102pp

Birol, E., Koundouri, P., \& Kountouris, Y. (2009). Using the choice experiment method to inform flood risk reduction policies in the Upper Silesia region of Poland.

Blaney, L. M., Cinar, S., \& SenGupta, A. K. (2007). Hybrid anion exchanger for trace phosphate removal from water and wastewater. Water Research, 41(7), 1603-1613.

Boyer, T., \& Polasky, S. (2004). Valuing urban wetlands: a review of non-market valuation studies. Wetlands, 24(4), 744-755.

Brouwer, R., \& Bateman, I. J. (2005). Temporal stability and transferability of models of willingness to pay for flood control and wetland conservation. Water Resources Research, 41(3).

Burns, J. (2008). Toxic cyanobacteria in Florida waters. In Cyanobacterial harmful algal blooms: state of the science and research needs (pp. 127-137). Springer New York. 
Butler, M. J., Hunt, J. H., Herrnkind, W. F., Childress, M. J., Bertelsen, R., Sharp, W., \& Marshall, H. G. (1995). Cascading disturbances in Florida Bay, USA: cyanobacteria blooms, sponge mortality, and implications for juvenile spiny lobsters Panulirus argus. Marine Ecology Progress Series, 129(1), 119-125.

Carlsson, F., Frykblom, P., \& Liljenstolpe, C. (2003). Valuing wetland attributes: an application of choice experiments. Ecological Economics, 47(1), 95-103.

Carter, N. T. (2001). South Florida Ecosystem Restoration and the Comprehensive Everglades Restoration Plan. Report No. RS20702, Washington, DC: National Council for Science and the Environment.

Chamberlain, R., \& Hayward, D. (1996). EVALUATION OF WATER QUALITY AND MONITORING IN THE ST. LUCIE ESTUARY, FLORIDA1. JAWRA Journal of the American Water Resources Association, 32(4), 681-696.

Chen, R., \& Twilley, R. R. (1999). Patterns of mangrove forest structure and soil nutrient dynamics along the Shark River Estuary, Florida. Estuaries, 22(4), 955-970.

Committee on Assessing and Valuing the Services of Aquatic and Related Terrestrial Ecosystems (CAVARSTE). (2004). Valuing Ecosystems Services: Toward Better Environmental Decision-Making. Washington D.C.: The National Academies Press

Costanza, R., d'Arge, R., de Groot, R., Farber, S., Grasso, M., Hannon, B., Limburg, K., Naeem, S., O’Neill, R.,Paruelo, J., Raskin, R., Sutton, P., van den Belt, M. (1997). The value of the world's ecosystem services and natural capital. Nature 387 (15), 253-260.

Costanza, R., \& Kubiszewski, I. (2012). The authorship structure of "ecosystem services" as a transdisciplinary field of scholarship. Ecosystem Services, 1(1), 16-25.

Costanza, R., de Groot, R., Sutton, P., van der Ploeg, S., Anderson, S. J., Kubiszewski, I., ... \& Turner, R. K. (2014). Changes in the global value of ecosystem services. Global Environmental Change, 26, 152-158.

Craft, C. B., Vymazal, J., \& Richardson, C. J. (1995). Response of Everglades plant communities to nitrogen and phosphorus additions. Wetlands, 15(3), 258-271.

Daily, G. (Ed.). (1997). Nature's services: societal dependence on natural ecosystems. Island Press.

Davis, S.M. (1991).Growth. decomposition and nutrient retention of Cladium jamaicense Crantz and Typha domingensis Pets. in the Florida Everglades. Aquatic Botany 40:203224 , 
Doering, P. H. (1996). Temporal Variability of Water Quality In The St. Lucie Estuary, South Florida. JAWRA Journal of the American Water Resources Association, 32(6), 1293-1306.

Douglas, M. S. (2007). The Everglades: river of grass. Pineapple Press Inc.

Glibert, P. M., Heil, C. A., Hollander, D. J., Revilla, M., Hoare, A., Alexander, J., \& Murasko, S. (2004). Evidence for dissolved organic nitrogen and phosphorus uptake during a cyanobacterial bloom in Florida Bay. Marine Ecology-Progress Series, 280, 73.

Godfrey, M. C., \& Catton, T. (2011). River of interests: water management in South Florida and the Everglades, 1948-2010.

Gonzalez, J. M., Loomis, J. B., \& Gonzalez-Caban, A. (2008). A joint estimation method to combine dichotomous choice CVM models with count data TCM models corrected for truncation and endogenous stratification. Journal of Agricultural and Applied Economics, 40(2), 681-695.

Gunderson, L., \& Light, S. S. (2006). Adaptive management and adaptive governance in the everglades ecosystem. Policy Sciences, 39(4), 323-334.

Florida Department of Environmental Protection. (2011). Water Quality Q\&A. Retrieved from http://www.dep.state.fl.us/evergladesforever/restoration/pdf/epa map.pdf

Florida Department of State: Division of Elections. (2014). Constitutional Amendment Petition Form. Retrieved from http://election.dos.state.fl.us/initiatives/fulltext/pdf/598941.pdf

Florida Division of Elections. (2014). 2014 Florida Election Watch. Retrieved from http://enight.elections.myflorida.com/Constitutional/Amendment.asp

Florida Everglades Forever Act. (1994). Florida State Legislature, Tallahassee, FL. Retrieved from http://www.law.miami.edu/library/everglades/statutes/state/florida/E_forever.htm

Florida Legislature Office of Economic and Demographic Research (OEDR). (2007). Florida Demographic Overview. Retrieved from http://edr.state.fl.us/Content/presentations/populationdemographics/DemographicOverview.pdf

Fisher, B., \& Turner, R. K. (2008). Ecosystem services: classification for valuation. Biological Conservation, 141(5), 1167-1169.

Fourqurean, J. W., \& Robblee, M. B. (1999). Florida Bay: a history of recent ecological changes. Estuaries, 22(2), 345-357. 
Furse, J. B., \& Fox, D. D. (1994). Economic fishery valuation of five vegetation communities in Lake Okeechobee, Florida. In Proceedings of the Annual Conference of Southeastern Association of Fish and Wildlife Agencies (Vol. 48, pp. 575-591).

Haab, T. C., \& McConnell, K. E. (2002). Valuing environmental and natural resources: the econometrics of non-market valuation. Edward Elgar Publishing.

Hall, M. O., Durako, M. J., Fourqurean, J. W., \& Zieman, J. C. (1999). Decadal changes in seagrass distribution and abundance in Florida Bay. Estuaries, 22(2), 445-459.

Hanley, N., Mourato, S., \& Wright, R. E. (2001). Choice Modelling Approaches: A Superior Alternative for Environmental Valuation?. Journal of economic surveys, 15(3), 435-462.

Harwell, M. A., Cooper, W., \& Flaak, R. (1992). Prioritizing ecological and human welfare risks from environmental stresses. Environmental Management, 16(4), 451-464.

Harwell, M.A., and Long, J.F. (1992). US MAB Human-Dominated Systems Directorate Workshop on Ecological Endpoints and Sustainability Goals. United States Man and the Biosphere Program. Rosensteil School of Marine and Atmospheric Science, University of Miami.

Harwell, M. A., Long, J. F., Bartuska, A. M., Gentile, J. H., Harwell, C. C., Myers, V., \& Ogden, J. C. (1996). Ecosystem management to achieve ecological sustainability: the case of South Florida. Environmental Management, 20(4), 497-521.

Harwell, M. A., Gentile, J. H., Bartuska, A., Harwell, C. C., Myers, V., Obeysekera, J., ... \& Tosini, S. C. (1999). A science-based strategy for ecological restoration in South Florida. Urban Ecosystems, 3(3-4), 201-222.

Holmquist, J. G., Powell, G. V., \& Sogard, S. M. (1989). Decapod and Stomatopod Communities of Seagrass-Covered Mud Banks in Florida Bay: Inter-and Intra-Bank Heterogeneity with Special Reference to Isola Ted Subenvironments. Bulletin of Marine Science, 44(1), 251-262.

Hoyos, D. (2010). The state of the art of environmental valuation with discrete choice experiments. Ecological economics, 69(8), 1595-1603.

Johnston, R. J., Segerson, K., Schultz, E. T., Besedin, E. Y., \& Ramachandran, M. (2011). Indices of biotic integrity in stated preference valuation of aquatic ecosystem services. Ecological Economics, 70(11), 1946-1956. 
Johnston, R. J., Schultz, E. T., Segerson, K., Besedin, E. Y., \& Ramachandran, M. (2012). Enhancing the content validity of stated preference valuation: the structure and function of ecological indicators. Land Economics, 88(1), 102-120.

Lancsar, E., \& Louviere, J. (2008). Conducting discrete choice experiments to inform healthcare decision making. Pharmacoeconomics, 26(8), 661-677.

Langevin, C. D. (2003). Simulation of submarine ground water discharge to a marine estuary: Biscayne Bay, Florida. Ground Water, 41(6), 758-771.

Light, S. S., \& Dineen, J. W. (1994). Water control in the Everglades: a historical perspective. Everglades: The ecosystem and its restoration, 47-84.

Loftus, W. F., \& Eklund, A. M. (1994). Long-term dynamics of an Everglades small-fish assemblage. Everglades: the Ecosystem and Its Restoration. St. Lucie Press, Delray Beach, FL, USA, 461-484.

Longland, M., Cesar, H., Sablan, J., Shjegstad, S., Beardmore, B., Liu, Y., \& Garces, G. O. (2007). The economic value of Guam's coral reefs. University of Guam Marine Laboratory.

Loomis, J., Kent, P., Strange, L., Fausch, K., \& Covich, A. (2000). Measuring the total economic value of restoring ecosystem services in an impaired river basin: results from a contingent valuation survey. Ecological economics, 33(1), 103-117.

Loomis, J. (2003). Travel cost demand model based river recreation benefit estimates with on-site and household surveys: Comparative results and a correction procedure. Water Resources Research, 39(4).

Loucks, D. P. (2008). Water Resource Management Models. The Bridge: Linking Engineering and Society, 24-30. Retrieved from http://www.nae.edu/File.aspx?id=7423

Martinez-Espineira, R., Loomis, J. B., Amoako-Tuffour, J., \& Hilbe, J. M. (2008). Comparing recreation benefits from on-site versus household surveys in count data travel cost demand models with overdispersion. Tourism Economics, 14(3), 567-576.

McCormick, B., Clement, R., Fischer, D., Lindsay, M., \& Watson, R. (2010). Measuring the Economic Benefits of America's Everglades Restoration. Palmetto Bay, FL: Study Prepared for The Everglades Foundation.

McLean, A. R., Ogden, J. C., \& Williams, E. E. (2002). Chapter 7: Comprehensive Everglades Restoration PLan. Retrieved from http://mytest.sfwmd.gov/portal/page/portal/pg_grp_sfwmd_sfer/portlet prevreport/2002 ecr/Chapters/Ch7.pdf 
Miami Dade Water And Sewer Department (WASD). (2013). All You Need To Know: About Your Miami-Dade Water and Sewer Department. Retrieved from http://www.miamidade.gov/water/library/brochures/about-water-sewer-department.pdf

Millennium Ecosystem Assessment Ecosystems and Human Well-Being: Synthesis (MA). (2005) Island Press, Washington, DC.

Milon, J.W., Hodges, A. W., Rimal, A., Kiker, C. F., \& Casey, F. (1999). Public preferences and economic values for restoration of the Everglades/South Florida ecosystem. Gainesville, FL, USA: University of Florida, Food \& Resource Economics Department, Florida Agricultural Experiment Station, Institute of Food and Agricultural Sciences.

Milon, J. W., \& Scrogin, D. (2005). Latent preferences and valuation of wetland ecosystem restoration. Ecological Economics, 56(2), 162-175.

Mumby, P. J., Edwards, A. J., Arias-González, J. E., Lindeman, K. C., Blackwell, P. G., Gall, A., ... \& Llewellyn, G. (2004). Mangroves enhance the biomass of coral reef fish communities in the Caribbean. Nature, 427(6974), 533-536.

Norrbin, S. (2011). Reviewer's Report of " Measuring the Economic Benefits of America's Everglades Restoration". Retrieved from http://aif.com/information/2011/Norrbin_Review.pdf

Ogden, J. C. (1994). A comparison of wading bird nesting colony dynamics (1931-1946 and 1974-1989) as an indication of ecosystem conditions in the southern Everglades. ST. LUCIE PRESS, BOCA RATON, FL(USA)., 533-570.

Orth, R. J., Carruthers, T. J., Dennison, W. C., Duarte, C. M., Fourqurean, J. W., Heck, K. L., ... \& Williams, S. L. (2006). A global crisis for seagrass ecosystems. Bioscience, 56(12), 987-996.

Perry, W. (2004). Elements of south Florida's comprehensive Everglades restoration plan. Ecotoxicology, 13(3), 185-193.

Perry, W. B. (2008). Everglades restoration and water quality challenges in south Florida. Ecotoxicology, 17(7), 569-578.

Rivera-Monroy, V. H., Twilley, R. R., Davis III, S. E., Childers, D. L., Simard, M., Chambers, R., \& Noe, G. B. (2011). The role of the Everglades Mangrove Ecotone Region (EMER) in regulating nutrient cycling and wetland productivity in south Florida. Critical Reviews in Environmental Science and Technology, 41(S1), 633-669.

Sathirathai, S., \& Barbier, E. B. (2001). Valuing mangrove conservation in southern Thailand. Contemporary Economic Policy, 19(2), 109-122. 
Serafy, S. E. (1998). Pricing the invaluable:: the value of the world's ecosystem services and natural capital. Ecological Economics, 25(1), 25-27.

Shoyama, K., Managi, S., \& Yamagata, Y. (2013). Public preferences for biodiversity conservation and climate-change mitigation: A choice experiment using ecosystem services indicators. Land Use Policy, 34, 282-293.

Shrestha, R. K., \& Alavalapati, J. R. (2004). Valuing environmental benefits of silvopasture practice: a case study of the Lake Okeechobee watershed in Florida. Ecological Economics, 49(3), 349-359.

Shultz, T. R., \& Lepper, M. R. (1996). Cognitive dissonance reduction as constraint satisfaction. Psychological review, 103(2), 219.

Sime, P. (2005). St. Lucie Estuary and Indian river lagoon conceptual ecological model. Wetlands, 25(4), 898-907.

South Florida Water Management District (SFWMD). 1992. Surface water improvement and management plan for the Everglades. Supporting information document. South Florida Water Management District, West Palm Beach, FL, USA.

State of Florida Office of Economic and Demographic Research (OEDR). (2014). Florida Population by County, 1970 through 2040. Retrieved from http://edr.state.fl.us/Content/population-demographics/data/CountyPopulation.pdf

Steinman, A., Havens, K., \& Hornung, L. (2002). The managed recession of Lake Okeechobee, Florida: integrating science and natural resource management. Conservation Ecology, 6(2), 17.

Thayer, G. W., \& Chester, A. J. (1989). Distribution and abundance of fishes among basin and channel habitats in Florida Bay. Bulletin of Marine Science, 44(1), 200-219.

UNEP-WCMC, 2006. In the Front Line: Shoreline Protection and Other Ecosystem Services from Mangroves and Coral Reefs. UNEP-WCMC,Cambridge.

U.S. Army Corps of Engineers (USACE)., \& South Florida Water Management District (SFWMD). (1999).Central and South Florida Project Comprehensive Review Study:

Final Integrated Feasibility Report and Programmatic Environmental Impact Statement. Retrieved from http://www.evergladesplan.org/docs/comp plan apr99/summary.pdf

U.S. Department of Commerce. (2012). Florida QuickLinks from the US Census Bureau. Retrieved from United States Census Bureau website: http://quickfacts.census.gov/qfd/states/120001k.html 
U.S. Department of the Interior (2014). National Park Visitor Spending Effects:

Economic Contributions to Local Communities, States, and the Nation. Retrieved from National Park Service website:

http://www.nature.nps.gov/socialscience/docs/NPSVSE2012_final_nrss.pdf

Voss, M. (2000). Central and Southern Florida Project Comprehensive Review Study: Restoring the Everglades, The. Ecology LQ, 27, 751.

Westerberg, V. H., Lifran, R., \& Olsen, S. B. (2010). To restore or not? A valuation of social and ecological functions of the Marais des Baux wetland in Southern France.

Ecological Economics, 69(12), 2383-2393.

Wetzel, P. R., van der Valk, A. G., Newman, S., Gawlik, D. E., Troxler Gann, T., Coronado-Molina, C. A., ... \& Sklar, F. H. (2005). Maintaining tree islands in the Florida Everglades: nutrient redistribution is the key. Frontiers in Ecology and the Environment, 3(7), 370-376.

Williams, C. D., Aubel, M. T., Chapman, A. D., \& D'Aiuto, P. E. (2007). Identification of cyanobacterial toxins in Florida's freshwater systems. Lake and Reservoir Management, 23(2), 144-152.

Wilson, C., Scotto, L., Scarpa, J., Volety, A., Laramore, S., \& Haunert, D. (2005). Survey of water quality, oyster reproduction and oyster health status in the St. Lucie Estuary. Journal of Shellfish Research, 24(1), 157-165.

Yentsch, C. S., Lapointe, B. E., Poulton, N., \& Phinney, D. A. (2008). Anatomy of a red tide bloom off the southwest coast of Florida. Harmful Algae, 7(6), 817-826. 


\section{APPENDICES}

Appendix A: Abridged Milon et al. (1999) adapted video script (First Video)

\begin{tabular}{|c|c|c|c|}
\hline Topic & Number & Description & Narrative \\
\hline Intro & 1 & $\begin{array}{l}\text { Sat view of } \\
\text { South Florida }\end{array}$ & $\begin{array}{l}\text { Viewed from high above, South Florida is } \\
\text { rich in water resources. Water practically } \\
\text { defines South Florida with its lakes, } \\
\text { estuaries, and the Everglades. The purpose } \\
\text { of this video is to provide you with } \\
\text { information about the historic nature of the } \\
\text { South Florida ecosystem and how that } \\
\text { ecosystem has been changed to provide } \\
\text { water related services to the people of } \\
\text { South Florida. }\end{array}$ \\
\hline $\begin{array}{l}\text { Geographic } \\
\text { Boundaries }\end{array}$ & 2 & $\begin{array}{l}\text { Historic } \\
\text { Everglades } \\
\text { Basin: Uplands, } \\
\text { Lowlands, } \\
\text { Open Water. }\end{array}$ & $\begin{array}{l}\text { Before the } 20^{\text {th }} \text { century, the defining feature } \\
\text { of South Florida was the Everglades } \\
\text { ecosystem. This system stretched from } \\
\text { north of Lake Okeechobee to the Florida } \\
\text { Keys in the South. The system was made up } \\
\text { of wetlands, upland areas, and open water. }\end{array}$ \\
\hline \multirow[t]{2}{*}{ Water Flow } & 3 & $\begin{array}{l}\text { Map of Historic } \\
\text { Flow of } \\
\text { Everglades }\end{array}$ & $\begin{array}{l}\text { Surface water flow, which made the } \\
\text { Everglades one of the largest freshwater } \\
\text { marshes in the world, started at Lake } \\
\text { Okeechobee and flowed like a river of grass } \\
\text { to Florida Bay at the southern end of the } \\
\text { state }\end{array}$ \\
\hline & 4 & $\begin{array}{l}\text { Photo of Saw } \\
\text { Grass Marsh }\end{array}$ & $\begin{array}{l}\text { Flow from the lake into the river of grass } \\
\text { varied over the season and from year to } \\
\text { year depending on rainfall. }\end{array}$ \\
\hline \multirow[t]{2}{*}{$\begin{array}{l}\text { Climatic } \\
\text { Conditions }\end{array}$} & 5 & $\begin{array}{l}\text { Diagram of the } \\
\text { hydrologic cycle }\end{array}$ & $\begin{array}{l}\text { This rainfall filled up surrounding marshes } \\
\text { and recharged groundwater aquifers. } \\
\text { Seasonal changes in rainfall affected the } \\
\text { timing and flow of water and determined } \\
\text { water levels in the Everglades. }\end{array}$ \\
\hline & 6 & $\begin{array}{l}\text { Chart showing } \\
\text { rainfall history } \\
\text { for SF from } \\
\text { 1992- present }\end{array}$ & $\begin{array}{l}\text { Rainfall in South Florida varies widely } \\
\text { from less than } 40 \text { inches in dry years to } \\
\text { more than } 60 \text { inches in wet years }\end{array}$ \\
\hline $\begin{array}{l}\text { Everglades } \\
\text { Flora and } \\
\text { Fauna }\end{array}$ & 7 & $\begin{array}{l}\text { Pic of saw grass } \\
\text { marsh }\end{array}$ & $\begin{array}{l}\text { The variability in weather and its effects on } \\
\text { water flow was the most important factor in } \\
\text { creating a wide variety of natural habitats. } \\
\text { Wetlands included saw grass marshes }\end{array}$ \\
\hline
\end{tabular}




\begin{tabular}{|c|c|c|c|}
\hline & 8 & $\begin{array}{l}\text { Pic of Tree } \\
\text { islands }\end{array}$ & $\begin{array}{l}\text { And tree islands, which established } \\
\text { themselves on higher ground within the } \\
\text { marshes }\end{array}$ \\
\hline & 9 & $\begin{array}{l}\text { Pic of cypress } \\
\text { swamp }\end{array}$ & There were also cypress swamps.... \\
\hline & 10 & $\begin{array}{l}\text { Image of tidal } \\
\text { creeks and bays }\end{array}$ & tidal creeks and bays.... \\
\hline & 11 & $\begin{array}{l}\text { Image of } \\
\text { mangroves }\end{array}$ & mangroves.... \\
\hline & 12 & $\begin{array}{l}\text { Image of sea } \\
\text { grass beds in FL } \\
\text { Bay }\end{array}$ & And sea grass beds in Florida Bay \\
\hline & 13 & $\begin{array}{l}\text { Image of } \\
\text { Hardwood } \\
\text { Hammocks }\end{array}$ & $\begin{array}{l}\text { The Everglades ecosystem also included } \\
\text { dry land habitats such as hardwood } \\
\text { hammocks, }\end{array}$ \\
\hline & 14 & $\begin{array}{l}\text { Image of Pine } \\
\text { forests }\end{array}$ & Pine forests... \\
\hline & 15 & Image of prairies & And prairies. \\
\hline & 16 & $\begin{array}{l}\text { Image of } \\
\text { Spoonbill }\end{array}$ & \multirow{5}{*}{$\begin{array}{l}\text { This blend of wetland and dry land habitat } \\
\text { created one of the most diverse wildlife } \\
\text { communities of any ecosystem in the world } \\
\text { Wetland areas supported more than } 35 \\
\text { species of water birds and } 50 \text { reptile } \\
\text { species. } \\
\text { Dry land areas supported more than } 35 \\
\text { species of mammals and a wide variety of } \\
\text { land birds. }\end{array}$} \\
\hline & 17 & Image of Egret & \\
\hline & 18 & $\begin{array}{l}\text { Image of } \\
\text { American } \\
\text { Alligator }\end{array}$ & \\
\hline & 19 & Image of Deer & \\
\hline & 20 & $\begin{array}{l}\text { Image of Scrub } \\
\text { Jay }\end{array}$ & \\
\hline \multirow[t]{2}{*}{ Geography } & 21 & $\begin{array}{l}\text { Picture of both } \\
\text { Historic Flow } \\
\text { and Current Flow } \\
\text { of Everglades }\end{array}$ & $\begin{array}{l}\text { In the past } 50 \text { years, the historic South } \\
\text { Florida ecosystem has been changed to } \\
\text { provide for a variety of water issues }\end{array}$ \\
\hline & 22 & $\begin{array}{l}\text { GIS based map } \\
\text { of SF }\end{array}$ & $\begin{array}{l}\text { As shown by the yellow line on the map, } \\
\text { more than } 50 \% \text { of the historic Everglades } \\
\text { has been drained to reclaim land for urban } \\
\text { development and agricultural use. The }\end{array}$ \\
\hline
\end{tabular}




\begin{tabular}{|c|c|c|c|}
\hline & & & $\begin{array}{l}\text { while area to the right shows urban } \\
\text { development along the Atlantic coast. The } \\
\text { green area directly beneath Lake } \\
\text { Okeechobee is farmland. }\end{array}$ \\
\hline & 23 & $\begin{array}{l}\text { Map outlining } \\
\text { the } 4 \text { areas } \\
\text { mentioned in } \\
\text { description }\end{array}$ & $\begin{array}{l}\text { The present water management system } \\
\text { divides the historic Everglades into four } \\
\text { separate regions: Lake Okeechobee, the } \\
\text { Everglades' Agricultural Area, Water } \\
\text { Conservation Areas, and Everglades } \\
\text { National Park. Water levels and flows in } \\
\text { each region can be managed separately } \\
\text { from the others. }\end{array}$ \\
\hline & 24 & $\begin{array}{l}\text { Image showing } \\
\text { current releases } \\
\text { of water to } \\
\text { estuaries from } \\
\text { Lake O }\end{array}$ & $\begin{array}{l}\text { During the wet season, water levels in Lake } \\
\text { Okeechobee and the Water Conservation } \\
\text { Areas are controlled by releases to the } \\
\text { Atlantic Ocean and Everglades National } \\
\text { Park. During the dry season, releases are } \\
\text { made to meet the agricultural, industrial, } \\
\text { and household water needs of South } \\
\text { Florida. }\end{array}$ \\
\hline $\begin{array}{l}\text { Services } \\
\text { Urban }\end{array}$ & 25 & $\begin{array}{l}\text { Image of } \\
\text { flooding of } \\
\text { residential area }\end{array}$ & $\begin{array}{l}\text { This system serves to prevent seasonal } \\
\text { flooding of residential areas although in } \\
\text { very wet years some areas still experience } \\
\text { problems }\end{array}$ \\
\hline & 26 & $\begin{array}{l}\text { Slide of water } \\
\text { pouring into } \\
\text { glass }\end{array}$ & $\begin{array}{l}\text { The Water Conservation Areas feed } \\
\text { underground aquifers that are the primary } \\
\text { water supply for South Florida's urban } \\
\text { population of six million people and } \\
\text { millions of tourists }\end{array}$ \\
\hline & 27 & $\begin{array}{l}\text { Slide of } \\
\text { Sprinkler in lawn }\end{array}$ & $\begin{array}{l}\text { Also, water is supplied for outdoor uses } \\
\text { such as watering lawns and washing cars }\end{array}$ \\
\hline & 28 & $\begin{array}{l}\text { Aerial photo } \\
\text { showing } \\
\text { ag. fields and } \\
\text { adjacent } \\
\text { canal }\end{array}$ & $\begin{array}{l}\text { The water management system provides } \\
\text { services to agriculture in the form of } \\
\text { drainage and irrigation, depending on the } \\
\text { time of year }\end{array}$ \\
\hline & 29 & $\begin{array}{l}\text { Photo of a } \\
\text { sugarcane } \\
\text { harvesting } \\
\text { operation }\end{array}$ & $\begin{array}{l}\text { There are about a half million acres of crop } \\
\text { land in the Everglades Agricultural Area } \\
\text { just south of Lake Okeechobee of which } \\
85 \% \text { is sugar cane }\end{array}$ \\
\hline & 30 & $\begin{array}{l}\text { Picture showing } \\
\text { current water } \\
\text { flow }\end{array}$ & $\begin{array}{l}\text { Unfortunately the present water } \\
\text { management system has resulted in many } \\
\text { unexpected consequences. A significantly } \\
\text { greater amount of water is now drained to } \\
\text { the Atlantic Ocean rather than flowing }\end{array}$ \\
\hline
\end{tabular}




\begin{tabular}{|c|c|c|}
\hline & & though the Everglades to Florida Bay. \\
\hline 31 & $\begin{array}{l}\text { Schematic image } \\
\text { of SF showing } \\
\text { drainage towards } \\
\text { estuaries }\end{array}$ & $\begin{array}{l}\text { More than four times as much water flows } \\
\text { to the Atlantic Ocean, causing damage to } \\
\text { coastal estuaries. A } 60 \% \text { reduction in } \\
\text { freshwater flows to Florida Bay has caused } \\
\text { increased salinity in the Bay. }\end{array}$ \\
\hline 32 & Image of heron & $\begin{array}{l}\text { These changes in water flow have affected } \\
\text { several Everglades habitats. Wetland } \\
\text { habitats for wading birds have been harmed } \\
\text { by decreased water flows to the lower } \\
\text { Everglades. }\end{array}$ \\
\hline 33 & $\begin{array}{l}\text { Image of wading } \\
\text { birds }\end{array}$ & $\begin{array}{l}\text { There has been about a } 90 \% \text { reduction in } \\
\text { the number of wading birds in the lower } \\
\text { Everglades in the last fifty years. Loss of } \\
\text { habitats has resulted in the listing of } 17 \\
\text { species of animals and birds as either } \\
\text { endangered or threatened in South Florida. }\end{array}$ \\
\hline 34 & $\begin{array}{l}\text { Aerial view of } \\
\text { FL Bay }\end{array}$ & $\begin{array}{l}\text { Changes in the timing and flow of } \\
\text { freshwater have also contributed to } \\
\text { unusually high levels of salinity in Florida } \\
\text { Bay }\end{array}$ \\
\hline 35 & $\begin{array}{l}\text { Image of } \\
\text { Shrimping Boat }\end{array}$ & $\begin{array}{l}\text { These changes in the Bay have also harmed } \\
\text { recreational fishing and the pink shrimp } \\
\text { industry in the Florida Keys. }\end{array}$ \\
\hline 36 & $\begin{array}{l}\text { Image of housing } \\
\text { development } \\
\text { adjacent to the } \\
\text { Everglades }\end{array}$ & $\begin{array}{l}\text { The growing population in South Florida } \\
\text { requires more water for household uses. } \\
\text { The increased demand puts pressure on } \\
\text { groundwater supplies and may lead to } \\
\text { future water shortages. }\end{array}$ \\
\hline 37 & $\begin{array}{l}\text { Photo of water } \\
\text { use restrictions } \\
\text { placard }\end{array}$ & $\begin{array}{l}\text { Reduced rainfall and low levels of } \\
\text { groundwater storage have sometimes led to } \\
\text { restrictions on household water use }\end{array}$ \\
\hline 38 & $\begin{array}{l}\text { Image of address } \\
\text { sign with a } \\
\text { direction to the } \\
\text { "FUTURE" }\end{array}$ & $\begin{array}{l}\text { A range of alternatives to change the } \\
\text { present water management system is being } \\
\text { considered. Many of these alternatives } \\
\text { would take a decade or more implement }\end{array}$ \\
\hline 39 & $\begin{array}{l}\text { Aerial view of } \\
\text { Mangrove forests } \\
\text { in Everglades }\end{array}$ & $\begin{array}{l}\text { The choice of which alternative to select } \\
\text { will depend upon public opinion. Any } \\
\text { decision will require tradeoffs between the } \\
\text { various services described in this video and } \\
\text { will have an impact on all Floridians }\end{array}$ \\
\hline 40 & $\begin{array}{l}\text { Slide with } \\
\text { SFWSC logo }\end{array}$ & \\
\hline
\end{tabular}


Appendix B: Modified Choice Card Video Script ( Third Video)

\begin{tabular}{|c|c|c|c|}
\hline Topic & $\begin{array}{l}\text { Slide } \\
\text { Num. }\end{array}$ & Slide Description & Narrative Text \\
\hline \multirow[t]{3}{*}{ Agriculture } & 1 & $\begin{array}{l}\text { Farmland in the } \\
\text { EAA }\end{array}$ & $\begin{array}{l}\text { Agriculture is one of the most } \\
\text { economically important industries in } \\
\text { south Florida. }\end{array}$ \\
\hline & 2 & $\begin{array}{l}\text { Aerial view of the } \\
\text { Everglades } \\
\text { Agricultural Area }\end{array}$ & $\begin{array}{l}\text { Close to } 700,000 \text { acres of farmland } \\
\text { are found south of Lake Okeechobee } \\
\text { (the Everglades Agricultural Area). }\end{array}$ \\
\hline & 3 & Lake O reservoir & $\begin{array}{l}\text { Increasing south Florida's reservoir } \\
\text { capacity by converting farmland or by } \\
\text { increasing water levels in Lake } \\
\text { Okeechobee will help ensure future } \\
\text { agriculture water demands are met, } \\
\text { and will have the added benefit of } \\
\text { increasing water supplies for natural } \\
\text { areas and urban centers. }\end{array}$ \\
\hline \multirow[t]{5}{*}{ Lake Okeechobee } & 4 & $\begin{array}{l}\text { Person holding a } \\
\text { bass from Lake O }\end{array}$ & $\begin{array}{l}\text { Lake Okeechobee supports a } \\
\text { recreational and commercial fishing } \\
\text { industry that is worth hundreds of } \\
\text { millions of dollars }\end{array}$ \\
\hline & 5 & Shoreline of Lake O & $\begin{array}{l}\text { The shoreline of the Lake provides } \\
\text { valuable wildlife habitat, especially } \\
\text { for wading birds. }\end{array}$ \\
\hline & 6 & $\begin{array}{l}\text { Fields being } \\
\text { irrigated }\end{array}$ & $\begin{array}{l}\text { It is also one of the primary sources } \\
\text { of drinking and irrigation water for } \\
\text { farmers in the region. }\end{array}$ \\
\hline & 7 & $\begin{array}{l}\text { Habitat around } \\
\text { Lake } \mathrm{O}\end{array}$ & $\begin{array}{l}\text { Water levels in Lake } \mathrm{O} \text { are controlled } \\
\text { as much as possible, since high water } \\
\text { levels in Lake Okeechobee damages } \\
\text { the shoreline habitat and could reduce } \\
\text { fish production. }\end{array}$ \\
\hline & 8 & $\begin{array}{l}\text { Aerial photo of } \\
\text { nutrient discharge } \\
\text { into the estuaries }\end{array}$ & $\begin{array}{l}\text { However, since the Lake also } \\
\text { contains high levels of nutrients its } \\
\text { waters cannot be discharged directly } \\
\text { into the Everglades. These nutrients } \\
\text { include nitrogen and phosphorous. } \\
\text { When these nutrients are discharged } \\
\text { through the canals to the estuaries, } \\
\text { they upset the ecosystem causing } \\
\text { considerable harm. }\end{array}$ \\
\hline Everglades WQ & & $\begin{array}{l}\text { Map showing } \\
\text { impacted areas with } \\
\text { the Everglades }\end{array}$ & $\begin{array}{l}\text { The nutrient rich runoff from the } \\
\text { Everglades Agricultural Area also } \\
\text { impacts the Water Conservation }\end{array}$ \\
\hline
\end{tabular}




\begin{tabular}{|c|c|c|c|}
\hline & & & $\begin{array}{l}\text { Areas and Everglades National Park. } \\
\text { The impacted areas are represented in } \\
\text { green on the map. }\end{array}$ \\
\hline & & $\begin{array}{l}\text { Image showing } \\
\text { alligators covered in } \\
\text { algae }\end{array}$ & $\begin{array}{l}\text { Nutrients like phosphorous change } \\
\text { the plant community and lower the } \\
\text { habitat value for wildlife in the } \\
\text { Everglades ... }\end{array}$ \\
\hline & & $\begin{array}{l}\text { Image of un- } \\
\text { impacted wetland }\end{array}$ & $\begin{array}{l}\text { Federal law dictates that the level of } \\
\text { phosphorous must remain under } 10 \\
\text { parts per billion which can only be } \\
\text { achieved through intensive treatment } \\
\text { with potential costs in the billions of } \\
\text { dollars. }\end{array}$ \\
\hline \multirow[t]{3}{*}{$\begin{array}{l}\text { St. Lucie and } \\
\text { Caloosahatchee }\end{array}$} & $\begin{array}{l}10 \\
11 \\
12\end{array}$ & $\begin{array}{l}\text { View of St. Lucie } \\
\text { and Caloosahatchee } \\
\text { Photo of Sport } \\
\text { fishing } \\
\text { Photo of wildlife } \\
\text { viewing } \\
\text { Photo of shellfish } \\
\text { harvests }\end{array}$ & $\begin{array}{l}\text { The St. Lucie and Caloosahatchee } \\
\text { estuaries on the Atlantic and Gulf } \\
\text { Coasts support a wide range of } \\
\text { ecosystem services, } \\
\text { including sport fishing, } \\
\text { wildlife viewing, } \\
\text { and shellfish harvests. The economy } \\
\text { and well-being of the communities } \\
\text { surrounding these estuaries depend on } \\
\text { these ecosystem services }\end{array}$ \\
\hline & 13 & $\begin{array}{l}\text { Photo of discolored } \\
\text { water between } \\
\text { canals and Lake }\end{array}$ & $\begin{array}{l}\text { However, excess water discharged } \\
\text { from Lake Okeechobee has an } \\
\text { extremely negative impact on the } \\
\text { health of these systems. This nutrient- } \\
\text { rich and often polluted water has been } \\
\text { linked to algae blooms, sea grass die } \\
\text { off, fish kills and poor health in } \\
\text { wildlife. }\end{array}$ \\
\hline & 14 & $\begin{array}{l}\text { Homes on St. Lucie } \\
\text { River w/algae } \\
\text { bloom }\end{array}$ & $\begin{array}{l}\text { It also poses a health hazard to } \\
\text { swimmers, and since the water is } \\
\text { discolored, it may lower the value of } \\
\text { nearby real estate. }\end{array}$ \\
\hline Water Supplies & 15 & $\begin{array}{l}\text { Photo of Everglades } \\
\text { wetlands }\end{array}$ & $\begin{array}{l}\text { High quality urban water supplies are } \\
\text { currently abundant in south Florida } \\
\text { but are threatened by an increasing } \\
\text { population and sea level rise. Much of } \\
\text { this water comes from the Everglades, } \\
\text { so efforts to improve water flows to } \\
\text { the Everglades will have a positive }\end{array}$ \\
\hline
\end{tabular}




\begin{tabular}{|c|c|c|c|}
\hline & & & effect on water supplies. \\
\hline & 16 & $\begin{array}{l}\text { Schematic of salt } \\
\text { water intrusion into } \\
\text { aquifer }\end{array}$ & $\begin{array}{l}\text { Increasing the amount of freshwater } \\
\text { available will help to offset the threats } \\
\text { to urban water supplies caused by } \\
\text { salt-water intrusion into underlying } \\
\text { aquifers. }\end{array}$ \\
\hline & 17 & $\begin{array}{l}\text { Picture of flood/ } \\
\text { rushing water } \\
\text { through canals }\end{array}$ & $\begin{array}{l}\text { Diverting water from the Everglades } \\
\text { to the canals throughout south } \\
\text { Florida's urban areas improves the } \\
\text { water supply, but also increases the } \\
\text { risk of flooding. Efforts to improve } \\
\text { water supplies for the Everglades and } \\
\text { for urban centers may continue to } \\
\text { increase the frequency of flooding. }\end{array}$ \\
\hline \multirow[t]{4}{*}{$\begin{array}{l}\text { Recreation in } \\
\text { Greater ENP, W } \\
\text { CA, Florida Bay }\end{array}$} & 18 & $\begin{array}{l}\text { Map of ENP and } \\
\text { Big Cypress }\end{array}$ & $\begin{array}{l}\text { The Greater Everglades ecosystem } \\
\text { includes Everglades National Park, } \\
\text { Big Cypress National Preserve, and } \\
\text { the Water Conservation Areas. }\end{array}$ \\
\hline & 19 & $\begin{array}{l}\text { Image of kayaking } \\
\text { in ENP }\end{array}$ & $\begin{array}{l}\text { These areas provide countless } \\
\text { recreational opportunities for tourists } \\
\text { and residents of south Florida, } \\
\text { including bird watching, boating, } \\
\text { kayaking, fishing, wildlife viewing, } \\
\text { camping, and hiking. }\end{array}$ \\
\hline & 21 & $\begin{array}{l}\text { Map showing WCA } \\
\text { recreation areas }\end{array}$ & $\begin{array}{l}\text { The Water Conservation Areas also } \\
\text { provide an area for many recreational } \\
\text { activities including, }\end{array}$ \\
\hline & 22 & $\begin{array}{l}\text { Image of airboat } \\
\text { tours }\end{array}$ & $\begin{array}{l}\text {...air boating, deer and duck hunting, } \\
\text { bird-watching, and frogging. }\end{array}$ \\
\hline \multirow[t]{4}{*}{ Florida Bay } & 23 & $\begin{array}{l}\text { Map showing extent } \\
\text { of Florida Bay }\end{array}$ & $\begin{array}{l}\text { Florida Bay lies between mainland } \\
\text { Florida and the Florida Keys. }\end{array}$ \\
\hline & 24 & $\begin{array}{l}\text { Sea grass beds in } \\
\text { Florida Bay }\end{array}$ & $\begin{array}{l}\text { The sea grass beds, mangrove islands, } \\
\text { and mud flats of the Bay provide vital } \\
\text { habitat for many threatened and } \\
\text { endangered species. }\end{array}$ \\
\hline & 25 & $\begin{array}{l}\text { Image of person } \\
\text { with Florida } \\
\text { Lobster }\end{array}$ & $\begin{array}{l}\text { The Bay also supports commercially- } \\
\text { important species such as the Florida } \\
\text { lobster, Pink shrimp, and sport fish. }\end{array}$ \\
\hline & 26 & $\begin{array}{l}\text { Algae Blooms in } \\
\text { Florida Bay }\end{array}$ & $\begin{array}{l}\text { Much of the economy of the Florida } \\
\text { Keys is based on the fisheries } \\
\text { supported by the Bay. In the past } \\
\text { several decades Florida Bay has been } \\
\text { subject to several large algae blooms } \\
\text { that have killed many thousands of } \\
\text { acres of valuable sea grass habitat }\end{array}$ \\
\hline
\end{tabular}




\begin{tabular}{|l|l|l|l|}
\hline & 27 & $\begin{array}{l}\text { View of Florida } \\
\text { Bay }\end{array}$ & $\begin{array}{l}\text { Reduced freshwater flows from the } \\
\text { Everglades, and high nutrient } \\
\text { discharges result in the overall decline } \\
\text { of the health of Florida Bay. }\end{array}$ \\
\hline & & $\begin{array}{l}\text { Therefore, returning the Everglades to } \\
\text { a more natural state by increasing the } \\
\text { amount of water flowing through the } \\
\text { system is expected to enhance its } \\
\text { value for wildlife and recreational } \\
\text { activities. }\end{array}$ \\
\hline $\begin{array}{l}\text { Restriction on } \\
\text { Urban Expansion }\end{array}$ & 31 & $\begin{array}{l}\text { Map of South } \\
\text { Florida showing } \\
\text { urban areas and } \\
\text { present } \\
\text { management system }\end{array}$ & $\begin{array}{l}\text { The population of South Florida is } \\
\text { expected to increase in the coming } \\
\text { decades. If the population growth is } \\
\text { similar to the growth experienced } \\
\text { over the last 50 years, development } \\
\text { will extend further along the } \\
\text { coastlines and further inland. }\end{array}$ \\
\hline 32 & $\begin{array}{l}\text { Image of urban } \\
\text { sprawl in South } \\
\text { Florida }\end{array}$ & $\begin{array}{l}\text { The proposed management plans seek } \\
\text { to lessen development and urban } \\
\text { sprawl in the lands in the west which } \\
\text { are needed to restore the Everglades } \\
\text { ecosystem and protect the region's } \\
\text { future water supply. }\end{array}$ \\
\hline 33 & $\begin{array}{l}\text { Image of Miami/ } \\
\text { with high rise } \\
\text { condos }\end{array}$ & $\begin{array}{l}\text { As such, these management plans will } \\
\text { limit the amount of westward urban } \\
\text { expansion to accommodate this } \\
\text { population growth, which in turn may } \\
\text { restrain future economic development } \\
\text { in the region. }\end{array}$ \\
\hline
\end{tabular}


Appendix C: Script for Explanatory Video 1 (Second Video)

\begin{tabular}{|c|c|c|}
\hline $\begin{array}{l}\text { Slide } \\
\text { Number }\end{array}$ & $\begin{array}{l}\text { Slide } \\
\text { Description }\end{array}$ & Narrative Text \\
\hline 1 & $\begin{array}{l}\text { Picture of } \\
\text { Everglades } \\
\text { wetlands }\end{array}$ & $\begin{array}{l}\text { As indicated by the previous video, several plans for } \\
\text { Everglades Restoration are currently under way }\end{array}$ \\
\hline 2 & Text Slide & $\begin{array}{l}\text { While restoring the Everglades will bring many benefits } \\
\text { to the Everglades ecosystem... }\end{array}$ \\
\hline 3 & Text Slide & $\begin{array}{l}\text {...these benefits will not come without certain tradeoffs } \\
\text { to all Floridians. }\end{array}$ \\
\hline 4 & Text Slide & $\begin{array}{l}\text { Tradeoffs occur when you are faced with a situation in } \\
\text { which you are giving something in order to gain } \\
\text { something else }\end{array}$ \\
\hline 5 & Text Slide & $\begin{array}{l}\text { Because of these tradeoffs it is important that you } \\
\text { express your opinion about what matters most to you } \\
\text { with regards to Everglades Restoration. }\end{array}$ \\
\hline 6 & Text Slide & $\begin{array}{l}\text { You will be asked to make a decision about which } \\
\text { restoration plan you would be willing to pay for }\end{array}$ \\
\hline 7 & $\begin{array}{l}\text { Image of a } \\
\text { Choice Card } 1\end{array}$ & $\begin{array}{l}\text { You will see a choice card, like this one, which will } \\
\text { have many attributes for you to consider in your } \\
\text { decision. In the } 1^{\text {st }} \text { choice card, you will be asked to } \\
\text { choose between ... }\end{array}$ \\
\hline 8 & $\begin{array}{l}\text { Image of Lake } \\
\text { Okeechobee }\end{array}$ & ...increasing water levels in Lake Okeechobee... \\
\hline 9 & $\begin{array}{l}\text { Image of Water } \\
\text { Conservation } \\
\text { Areas }\end{array}$ & ... water conservation areas... \\
\hline 10 & $\begin{array}{l}\text { Map showing } \\
\text { ENP }\end{array}$ & $\ldots$ and the Everglades National Park. \\
\hline 11 & Text Slide & $\begin{array}{l}\text { These increases in water flow will provide many } \\
\text { benefits to the Everglades }\end{array}$ \\
\hline 12 & Text Slide & $\begin{array}{l}\text { However you must weigh your options between } \\
\text { increasing water levels in those } 3 \text { areas or... }\end{array}$ \\
\hline 13 & $\begin{array}{l}\text { Image of } \\
\text { farmland }\end{array}$ & $\begin{array}{l}\text {... accepting changes in farmland acreage. In order to } \\
\text { support the increases in water levels farmland must be } \\
\text { converted back to wetlands, which leave less land for } \\
\text { valuable agricultural production. }\end{array}$ \\
\hline 14 & $\begin{array}{l}\text { Icon for water } \\
\text { restrictions }\end{array}$ & $\begin{array}{l}\text { You must also consider the reduction in farmland } \\
\text { against the possibility of restrictions on your water use. } \\
\text { The water demands from urban areas are expected to } \\
\text { increase in the future, so water restrictions may be } \\
\text { likely. }\end{array}$ \\
\hline 15 & $\begin{array}{l}\text { Image of the } 2^{\text {nd }} \\
\text { choice card }\end{array}$ & $\begin{array}{l}\text { In the } 2^{\text {nd }} \text { choice card, you will be asked to consider } \\
\text { those same options except while considering the }\end{array}$ \\
\hline
\end{tabular}




\begin{tabular}{|l|l|l|}
\hline & & restoration of various species groups. \\
\hline 16 & Text slide & $\begin{array}{l}\text { Similar principles apply with this choice card. You must } \\
\text { weigh the restoration of various species groups against } \\
\text { the tradeoffs. }\end{array}$ \\
\hline 17 & Text Slide & $\begin{array}{l}\text { Please consider these choices and their potential benefits } \\
\text { carefully when making your decision. Remember your } \\
\text { decision is important }\end{array}$ \\
\hline
\end{tabular}


Appendix D: Script for Explanatory 2 Video (Fourth Video)

\begin{tabular}{|c|c|c|}
\hline $\begin{array}{l}\text { Slide } \\
\text { Number }\end{array}$ & Slide Description & Narrative Text \\
\hline 1 & Text Slide & $\begin{array}{l}\text { In the video you most recently viewed, you were } \\
\text { given information about the consequences of } \\
\text { controlling water flow in the Everglades }\end{array}$ \\
\hline 2 & Text Slide & $\begin{array}{l}\text { You will now see another set of choice cards for } \\
\text { which you will choose a management plan that you } \\
\text { are most willing to pay for }\end{array}$ \\
\hline 3 & Text Slide & $\begin{array}{l}\text { Again this choice card will incorporate tradeoffs } \\
\text { between attributes like... }\end{array}$ \\
\hline 4 & $\begin{array}{l}\text { Image of irrigated } \\
\text { fields }\end{array}$ & $\ldots$ agricultural water demands \\
\hline 5 & $\begin{array}{l}\text { Cartoon house } \\
\text { flooding }\end{array}$ & ... urban flood risk \\
\hline 6 & $\begin{array}{l}\text { Image of man } \\
\text { holding fish from } \\
\text { ENP }\end{array}$ & ... recreational opportunities \\
\hline 7 & $\begin{array}{l}\text { Image of Miami } \\
\text { high rise condos }\end{array}$ & ... restrictions on urban expansion \\
\hline 8 & Text Slide & $\ldots$ and a few other attributes \\
\hline 10 & Text Slide & $\begin{array}{l}\text { You must consider the relationships between these } \\
\text { attributes }\end{array}$ \\
\hline 11 & Text Slide & $\begin{array}{l}\text { Increasing the water flow through the Everglades will } \\
\text { benefit... }\end{array}$ \\
\hline 12 & $\begin{array}{l}\text { Image of man } \\
\text { holding fish from } \\
\text { ENP }\end{array}$ & $\begin{array}{l}\text {...access to recreation in the Everglades National } \\
\text { Park, }\end{array}$ \\
\hline \multirow[t]{2}{*}{13} & $\begin{array}{l}\text { Image of kayaks } \\
\text { in Florida Bay }\end{array}$ & \multirow[t]{2}{*}{ Florida Bay, and the Water Conservation Areas } \\
\hline & $\begin{array}{l}\text { Image of Air } \\
\text { boating }\end{array}$ & \\
\hline 14 & $\begin{array}{l}\text { Image of glass of } \\
\text { water }\end{array}$ & $\begin{array}{l}\text { It will also increase the availability of drinking water } \\
\text { for municipal }\end{array}$ \\
\hline \multirow[t]{2}{*}{15} & $\begin{array}{l}\text { Image of irrigated } \\
\text { fields }\end{array}$ & ...and agricultural supplies \\
\hline & $\begin{array}{l}\text { Image of aerial } \\
\text { view of } \\
\text { mangroves }\end{array}$ & $\begin{array}{l}\ldots \text { and improve freshwater water quality throughout } \\
\text { the Everglades }\end{array}$ \\
\hline 16 & $\begin{array}{l}\text { Image of dirty } \\
\text { water teardrops }\end{array}$ & And within the coastal estuaries \\
\hline 17 & Text Slide & $\begin{array}{l}\text { However increasing water flow through the } \\
\text { Everglades will also... }\end{array}$ \\
\hline 19 & Cartoon image of & ... reduce the abundance of fish in Lake Okeechobee. \\
\hline
\end{tabular}




\begin{tabular}{|c|c|c|}
\hline & fishes in lake & \\
\hline 20 & $\begin{array}{l}\text { Cartoon house } \\
\text { flooding }\end{array}$ & increase the risk of urban flooding \\
\hline 21 & $\begin{array}{l}\text { Aerial view of } \\
\text { development on } \\
\text { Miami beach }\end{array}$ & $\ldots$ and imposes restrictions on urban expansion \\
\hline 22 & Text slide & $\begin{array}{l}\text { Please consider these tradeoffs carefully when making } \\
\text { your decision. Remember your decision is important }\end{array}$ \\
\hline
\end{tabular}

